\title{
Pleistocene and Holocene Palaeoenvironmental Reconstruction of the Carpathian Basin Based on Multiproxy Analysis of Cervid Teeth
}

Bence Szabóa,b,c*, Piroska Pazonyi ${ }^{c}$, Emőke Tóth ${ }^{\mathrm{a}}$, Enikő K. Magyari ${ }^{\mathrm{b}, \mathrm{c}, \mathrm{d}}$, Gabriella Ilona Kiss ${ }^{\mathrm{b}}$, László Rinyu ${ }^{\mathrm{b}}$, István Futób, Attila Virág ${ }^{\mathrm{c}}$

*e-mail: szabobence.pal@gmail.com

${ }^{a}$ Eötvös Loránd University, Department of Palaeontology, 1/c Pázmány Péter sétány, Budapest, Hungary, H-1117;

bIsotope Climatology and Environmental Research Centre (ICER), Institute for Nuclear Research, Bem tér 18/c, Debrecen, Hungary, H-4026;

`MTA-MTM-ELTE Research Group for Paleontology, 1/c Pázmány Péter sétány, Budapest, Hungary, H-1117;

dEötvös Loránd University, Department of Environmental and Landscape Geography, 1/c Pázmány Péter sétány, Budapest, Hungary, H-1117 


\title{
Pleistocene and Holocene Palaeoenvironmental Reconstruction of the Carpathian Basin Based on Multiproxy Analysis of Cervid Teeth
}

\begin{abstract}
During the Pleistocene and Holocene, large scale climatic changes occurred, resulting in severe environmental changes. Such changes in the Carpathian Basin were examined using dental elements of cervids from localities of Slovakia and Hungary. Their dental wear and the stable carbon and oxygen isotope values of structural carbonate and phosphate in bio-apatite of enamel was measured. Dental wear reflects the long and short term changes of past vegetation, and stable isotope analyses can be used to uncover palaeotemperature and photosynthetic pathways of the consumed plants, thus indirectly providing information on the vegetation. The changes of mesowear scores, from the early Pleistocene onwards, indicate a gradual transition from a more or less closed to an open environment, as climate got cooler. The results of microwear analysis suggest that even though the environment became more open, some tree cover remained in the Carpathian Basin, even in the glacial periods. Based on the measured $\delta^{18} \mathrm{O}$ values for glacial periods, estimated temperatures were approximately $5-6^{\circ} \mathrm{C}$ cooler, whereas for interglacials, temperatures were similar to the recent climate of Hungary. The $\delta^{13} \mathrm{C}$ values of the examined cervids suggest predominantly $\mathrm{C}_{3}$ plant consumption, which agrees with the fact that $\mathrm{C}_{4}$ plants are scarcer in colder environments.
\end{abstract}

Keywords: Dental mesowear; Dental microwear; Stable isotope analyses; Palaeovegetation; Ungulate diet

\section{Introduction}

The climatic variability of the Pleistocene and Holocene periods has been characterized by very large fluctuations in global ice volume. The largest changes in the volume of said glacial ice occurred in the Northern Hemisphere, where vast lands are present for ice to form on (e.g., Evans et al. 1977; Berger et al. 1993; Huybrechts 2002). These constant changes of the glacial/interglacial climatic cycles strongly modify terrestrial vegetation belts, extensively affecting terrestrial ecosystems (Faure et al. 2002; Zazula et al. 2003). As a response to these changes, some animals migrated, 
following their preferred vegetation or climate, while others remained more or less in place enduring actual climatic conditions.

One large herbivore group that remained in the Carpathian Basin during both the glacials and interglacials of the Quaternary are cervids. Some cervid species disappeared and reappeared as warmer and colder periods fluctuated (e.g., Rangifer tarandus), whereas others remained in the basin constantly (e.g., Cervus elaphus). The environmental tolerances of the cervids are quite wide (e.g., Renecker and Hudson 1990; Gebert and Verheyden-Tixier 2001; Jackson 1997; Kojola et al. 1998). Their constant presence throughout the Pleistocene and Holocene makes them an ideal group for paleoenvironmental purposes.

Meso- and microwear analyses are methods both based on the differing wear properties of the diet of animals. These methods are widely utilized in paleoenvironmental studies because of their fast and straightforward sample procession. Mesowear focuses on the long-term connection between the dentition and the diet, thus it could provide information about the typical forage consumed by the animal during longer periods of its life (e.g., Fortelius and Solounias 2000; Kaiser and Fortelius 2003; Kaiser and Solounias 2003). Based on this, we can gather rough information about the long-term vegetation, and consequently the climate of a region (e.g., Saarinen and Lister 2016; Yamada et al. 2016; Saarinen and Karme 2017). The other common dental wear method, microwear analysis, focuses on the short-term effects of diet on the dentition. The microscopic scars left by the foraged plants show specific traits depending on the diet, and are overwritten quickly, thus reflecting only the last few meals of an animal (Grine 1986). This could also help to make assumptions about the composition and the seasonality of the vegetation (e.g., Rivals et al. 2015; Semprebon et al. 2016; Sánchez- 
Hernández et al. 2016; Henton et al. 2017) and behavioural plasticity of given taxa (Rivals and Semprebon 2017).

Investigating the stable isotopic compositions of biomineralized tissues, such as dental enamel, can improve our understanding of past climates and dietary behaviors of mammals (e.g., Tütken et al. 2006; Martin et al. 2008; Kohn 2010; Pushkina et al. 2014). Compared to bone and dentine, enamel has a low organic content, larger average crystal size and a lower porosity, making it much more resistant to diagenetic alterations (Kohn et al. 1999; Skinner 2005). The stable oxygen isotopic composition of phosphate $\left(\delta^{18} \mathrm{O}_{\mathrm{PO} 4}\right)$ and structural carbonate $\left(\delta^{18} \mathrm{O}_{\mathrm{CO} 3}\right)$ of the enamel can be linked to the bodily fluids of animals. The isotopic composition of the body water of obligate drinkers is partially related to the oxygen isotopic composition of environmental water, which is dependent on climate (e.g., Longinelli 1984; Luz and Kolodny 1985). Cervids obtain around $60-75 \%$ of their total water intake from voluntary drinking water intake, thus the isotopic composition of their body water roughly represents the chemical composition of precipitation (Alexander and Segiura 1990). Because of the strong P-O bonds, the phosphate oxygen (compared to the carbonate oxygen) is considered more resistant to inorganic alterations, making it more suitable for climatic reconstructions (e.g., Kohn et al. 1999; Vennemann et al. 2002). The stable carbon isotopic composition of the structural carbonate of enamel is partially dependent on the diet of mammals. Through extracting a $\delta^{13} \mathrm{C}$ value, it becomes possible to reveal some properties (such as the $\mathrm{C}_{4}$ plant, i.e. predominantly the grass content) of past vegetations (e.g., Cerling and Harris 1999; Passey et al. 2005).

Complex environmental reconstructions of the Pleistocene and Holocene in the Carpathian Basin based on large mammals are scarce. Most isotope data are from proboscideans and rhinoceroses (Kovács et al. 2012; Virág et al. 2014; Kovács et al. 
2015), and dental wear methods were only used on some proboscideans (Virág 2013, Haiduc et al. 2018). Studies that use dental wear and stable isotope analyses simultaneously are rare which makes, evaluating and comparing the results of such methods difficult (e.g., Tütken et al. 2013; Rivals et al. 2015), even on a global scale. The aim of this study is to make up for this scarcity of Quaternary paleoenvironmental data in the Carpathian Basin, using a locally understudied large mammal group, the cervids. Furthermore, this study could also encourage other researchers to utilise multiproxy analyses to obtain better and more reliable palaeoenvironmental results from vertebrate assemblages.

\section{Materials}

The geographic distribution of Pleistocene and Holocene cervid bearing localities selected for the present study and their estimated age are shown in Figure 1, Figure 2, and in Table 1. The examined localities cover most of the middle to late Pleistocene and Holocene. However, there are some gaps in this time interval, as well. The two major gaps from this interval range from about $130 \mathrm{ka}$ to $90 \mathrm{ka}$, and from about $650 \mathrm{ka}$ to 500 ka. The former interval includes most of the Marine Isotope Stage (MIS) 5, and the latter includes MIS 14 and 15. The biggest gap in our database is from the early Pleistocene. No localities were included from the interval ranging from 1.25 Ma to 800 ka, due to the lack of localities with such age, and in the case of known localities the lack of cervid materials. All of the studied teeth were recovered from cave sediments, apart those from Zebegény, Zalaegerszeg, Mogyorósbánya, Pilismarót and Ságvár, which are open air archaeological sites.

Cervids, as a taxonomic group, are generalist herbivores (e.g. Jenkins and Wright 1988; Launchbaugh and Urness 1992, Rivals and Lister 2016). Individuals of the genera 
Alces (elk), Capreolus (roe deer), Cervus (red deer), Dama (fallow deer), Megaloceros (irish elk) and Rangifer (reindeer) were present in Hungary throughout the Pleistocene and Holocene, and their teeth are one of the most common remains from these aforementioned periods. Their abundance and wide stratigraphic distribution throughout the Quaternary makes them an ideal group for palaeoenvironmental investigations. For the dental wear analyses, in total 727 molars and premolars were selected from adult specimens from one Slovakian and 27 Hungarian localities. From these, 74 molars were in adequate condition for the low-magnification microwear analysis. Samples of tooth enamel for stable isotope analyses were collected from 31 specimens from one Slovakian and eight Hungarian localities. The samples for this study were acquired from the collections of the Hungarian Natural History Museum, Department of Palaeontology and Geology (Budapest), the Mining and Geological Survey of Hungary, Department of Geological and Geophysical Collections (Budapest) and the Archaeozoological collection of the Hungarian National Museum (Budapest). The list of the selected specimens with all necessary identification information and the different examinations performed on are found in the Supplementary material (Table S1).

\section{Methods}

\section{Dental mesowear analysis}

The mesowear analysis, executed following the method proposed by Mihlbachler et al. (2011), focuses on the long-term, lifelong connection between the dentition of an animal and its forage. Depending on the composition of the consumed plants, the enamel facets of teeth could develop in different ways. The consumption of hard, abrasive plant materials increases food-to-tooth contact (abrasion), eradicating facets and eventually resulting in worn down, abraded teeth. On the other hand, the 
consumption of soft plant materials decreases food-to-tooth contact and increases toothto-tooth contact (attrition). This process constantly creates facets, resulting in teeth with sharp edges and pointed apices. The mesowear analysis focuses on the buccal shearing edges of the enamel surfaces of upper molars, and the lingual shearing edges of the lower molars. Applying the mesowear-ruler developed by Mihlbachler et al. (2011), the selected teeth were divided into seven mesowear categories, receiving scores ranging from 0 to 6 based on their facet development. Stage 0 is interpreted as an extreme browser, consuming almost exclusively soft plant materials, having teeth with high and sharp cusps. On the other hand, stage 6 is interpreted as an extreme grazer, consuming almost exclusively abrasive plant materials, having teeth with completely abraded, flat cusps. The scores in between indicate an increasing portion of abrasive plant materials in the diet of the animal (Mihlbachler et al. 2011). The main dietary categories were separated by Rivals and Semprebon (2017) as follows: browsers are specimens with mesowear scores between 0 and 2, mixed-feeders are specimens with a mesowear index between 0.5 and 3 , whereas grazers are specimens, whose mesowear index is higher than 2. Based on this aforementioned article, we used the following dietary categories in this study: clear browsers were specimens with scores between 0 and 0.5 ; browsedominated mixed feeders were those specimens, that fell into the overlapping part of the browser and mixed feeder interval, falling between 0.5 and 2; graze-dominated mixed feeders were those specimens falling into the overlapping part of the mixed feeder and grazer categories, with index values between 2 and 3; grazers were specimens with mesowear scores higher than 3. Unworn and fully-abraded molars were excluded from the analysis, for their inclusion could provide misleading dietary interpretation (Kaiser and Fortelius 2003; Rivals and Solounias 2007). Scoring was done based on high definition photographs of the molars of the selected specimens. 


\section{Dental microwear analysis}

The other dental wear method, microwear analysis focuses on short term dietary preferences of an animal. The microwear observed on the enamel surface is constantly rewritten every few days, representing the abrasive properties of the most recently consumed forage items (Grine 1986). Microwear analysis was conducted on high resolution epoxy replicas of the selected specimens following the methodology of Solounias and Semprebon (2002) and Semprebon et al. (2004). Before casting, the surface of the teeth were thoroughly cleaned with acetone and ethanol, to remove debris, glue, or other contamination from the enamel surfaces. After cleaning the specimens a polyvinylsiloxane mold was made using Coltene Affinis Precious light body fast dental impression material. These molds were then cast using Epo-Tek 301 resin. The high resolution of both these materials enables the observation and quantification of micron scale scars on the enamel surface.

The enamel of teeth might be a sturdy material, but it is still susceptible to damage caused by the consumed forage items. On a microscopic scale, two kinds of such enamel scars are the most common: scratches and pits, which can be identified based on their shapes and refraction properties. Pits are scars that have approximately similar width and length; whereas scratches are elongated features with straight, parallel sides. By carefully adjusting the angle, in which the light strikes the casts, pits and scratches become separable based on their refractive properties. Small pits, fine and coarse scratches have high refractivity, they can become relatively bright under certain lightning properties. Large pits and hypercoarse scratches are less refractive, they always remain darker. Fine, coarse and hypercoarse scratches, as well as small and large pits were not differentiated from each other (see Solounias and Semprebon (2002) and Semprebon et al. (2004) for details). Scratches and pits were quantified under $35 \times$ magnification on five $0.16 \mathrm{~mm}^{2}$ areas (measured with an ocular micrometre) on each 
specimen if possible, and averaged to best represent the microwear signal of a given specimen (Szabó and Virág in press). If possible, upper and lower second molars were selected, for they are the most widely utilized teeth for such analyses. However, if other molars or premolars were in adequately fine condition, they were also included, for their microwear signal is similar to that of the second molars (Xafis et al. 2017; Szabó and Virág in press).

\section{Stable isotope analysis}

Samples of tooth enamel for stable isotope analyses were collected from 31 specimens from one Slovakian and eight Hungarian localities. Each selected tooth was thoroughly cleaned with ethanol and distilled water. After the cleaning, the teeth were dried. Bulk powdered enamel samples were collected from each tooth. The samples were taken from the metaconules and hypoconids of the teeth. For the sampling tungsten-carbide coated drill bits were used, to avoid any contamination with extraneous materials, the drill bits were thoroughly cleaned between each sampling. The enamel was ground from the bottom, to the top of the tooth crown, thus representing the whole dental development period of a given animal's life. Due to the destructive sampling method, to ensure minimal degradation of the collections material, only a small amount of enamel samples could be collected. A subset of all samples were selected for both $\delta^{18} \mathrm{O}_{\mathrm{PO} 4}$ and $\delta^{18} \mathrm{O}_{\mathrm{CO} 3}$ analyses, to check for diagenetic alteration (see Table S1. for details). Based on the results of the subset samples, specimens from the same localities were deemed altered or unaltered, and analysed furthermore accordingly.

All isotope analyses were performed in the Isotope Climatology and Environmental Research Centre, Institute for Nuclear Research, Debrecen, Hungary. 
For the ${ }^{18} \mathrm{O}$ measurement of the phosphate, $3 \mathrm{mg}$ of ground enamel was used. Calcium-acetate/acetic acid buffer ( $1 \mathrm{~mol} / \mathrm{L}, \mathrm{pH} 5.0)$, hydrogen peroxide $(10 \mathrm{w} / \mathrm{w} \%)$ and sodium hypochlorite $(12 \mathrm{w} / \mathrm{w} \%)$ were used to get rid of organic components and secondary carbonates from the bioapatite. Afterwards, the phosphate content of the samples were dissolved in hydrogen fluoride $(2 \mathrm{~mol} / \mathrm{L})$, then it was precipitated in silver phosphate form by adding silver nitrate $(2 \mathrm{~mol} / \mathrm{L}$ ) to the solute (Garvie-Lok et al. 2004; Bassett et al. 2007; Szabó et al. 2017). The phosphate $\delta^{18} \mathrm{O}$ was determined in a DeltaPLUS XP isotope ratio mass spectrometer equipped with a high temperature elemental analyzer. The measurement sequence was calibrated with known isotopic phosphate standards: the international $\mathrm{B} 2207\left(\delta^{18} \mathrm{O}_{\mathrm{VSMOW}}=+21.7 \%\right)$ and our in-house standard $\left(\delta^{18} \mathrm{O}_{\text {VSMOW }}=+12.26 \%\right.$ determined in University of Lausanne $)$. The standard deviation of the $\delta^{18} \mathrm{O}$ analysis was $0.3 \%$.

Since the carbonate content of the enamel samples were very low, a large amount $(\sim 1 \mathrm{mg})$ of bioapatite was used for the analysis of the ${ }^{18} \mathrm{O}$ and ${ }^{13} \mathrm{C}$ content of the carbonate. The sample materials were digested with phosphoric acid (over 104\% cc.) in a Kiel IV automated carbonate extraction device. The liberated $\mathrm{CO}_{2}$ was then admitted to a MAT 235 Plus high resolution isotope ratio mass spectrometer. The results were normalized against three types of international carbonate reference material (NBS-18, NBS-19 and IAEA-LSVEC) which were measured in the same carousel with the unknown samples. The standard deviation of the $\delta^{13} \mathrm{C}$ and $\delta^{18} \mathrm{O}$ analysis were $0.05 \%$ and $0.08 \%$, respectively.

\section{$\delta^{18} \mathrm{O}$ analysis}

The measured $\delta^{18} \mathrm{O}_{\mathrm{PO} 4}$ values are directly related to the oxygen isotopic composition of the body fluids of the cervids, which is directly related to the isotopic composition of their drinking water, and so the precipitation as well (Longinelli 1984; 
Luz et al. 1984; Bryant and Froelich 1995). The isotopic composition of precipitation is influenced by many factors, such as temperature, latitude, altitude and continental effects (Zanazzi et al. 2015). Precipitation is enriched in heavy oxygen isotopes in warmer climates, and as the wind systems carry it from warmer to cooler areas, it gradually loses its heavy ${ }^{18} \mathrm{O}$-enriched water component (Dansgaard 1964). This makes it possible to calculate a mean annual temperature (MAT) for past times from the $\delta^{18} \mathrm{O}$ values of precipitation.

To evaluate this relationship between MAT and precipitation isotopic composition in the Carpathian Basin, a database was established from the data of seven GNIP (Global Network of Isotopes in Precipitation) laboratories. These seven locations are from Austria (Hohe Warte), Croatia (Zagreb-Grič), Hungary (Debrecen) and Slovakia (Bratislava, Milhostov, Mochove, Topol'níky). The inclusion of these four countries should represent the connection between the temperature and water isotopic composition in the Carpathian Basin well. The database includes 1762 registries, with the country, the laboratories, the latitude and longitude, the altitude, the $\delta^{18} \mathrm{O}$ value of precipitation, the amount of precipitation and the measured air temperature for each one (Table S2). A standard major axis regression (MAR) was calculated for the air temperature and the $\delta^{18} \mathrm{O}$ value of precipitation (Figure 3). The MAR was chosen over an ordinary least squares regression (OLS) because both examined variables were measured, thus both variables are burdened with measurement errors. MAR can deal with such a problem, whereas an OLS is not viable in a situation like this (Smith 2009; Ludbrook 2010). Based on the results of the MAR, a strong linear positive correlation can be made between the temperature and the precipitation isotopic composition $\left(r^{2}=0.4758\right)$ :

$$
\mathrm{MAT}=1.95 \times \delta^{18} \mathrm{O}_{\mathrm{H} 2 \mathrm{O}}+27.67
$$


To calculate an MAT from enamel phosphate, it is also necessary to evaluate the connection between the $\delta^{18} \mathrm{O}_{\mathrm{PO} 4}$ and the $\delta^{18} \mathrm{O}_{\mathrm{H} 2 \mathrm{O}}$. Another database was built from extant artiodactyls from literature: Bovidae (Bos primigenius, Ovis aries), Cervidae (Cervus canadensis, C. elaphus, D. dama, R. tarandus) and Suidae (Sus scrofa) (Longinelli 1984; D'Angela and Longinelli 1990; Fricke et al. 1998; Iacumin and Longinelli 2002). This database consists of phosphate isotopic measurements of tooth enamel and bone, the species, the locality, the measured $\delta^{18} \mathrm{O}_{\mathrm{PO} 4}$ and the estimated $\delta^{18} \mathrm{O}_{\mathrm{H} 2 \mathrm{O}}$ of the drinking water of these specimens (Table S3). The relationship between the two variables in question was also checked with an MAR for the aforementioned reasons (Figure 4). There was a strong, linear, positive correlation between the two variables $\left(r^{2}=0.7158\right)$ :

$$
\delta^{18} \mathrm{O}_{\mathrm{H} 2 \mathrm{O}}=\left(\delta^{18} \mathrm{O}_{\mathrm{PO} 4}-21.39\right) / 0.74
$$

Using these equations, it is possible to calculate a precipitation isotopic composition from the enamel phosphate of a given specimen, and after, to calculate an MAT from the previously calculated $\delta^{18} \mathrm{O}_{\mathrm{H} 2 \mathrm{O}}$ value. Thus, it is possible to evaluate the paleotemperature of the Carpathian Basin based on the bulk enamel samples taken from the Pleistocene and Holocene cervid specimens.

\section{$\delta^{13} C$ analysis}

Carbon fixation in plants can follow three different photosynthetic pathways: $\mathrm{C}_{3}$ (Hatche-Slack cycle), $\mathrm{C}_{4}$ (Calvine-Benson cycle) and CAM (Crassulacean Acid Metabolism) (Smith and Epstein, 1971; Dawson et al. 2002). In $C_{3}$ photosynthesis, the oxygen sensitive RUBISCO (ribulose-bis-phosphate carboxylase/oxygenase) fixes $\mathrm{CO}_{2}$, resulting in phosphoglyceric-acid as its first stable $\mathrm{C}_{3}$ product. The measurable $\delta^{13} \mathrm{C}$ values in plants utilizing the $\mathrm{C}_{3}$ pathway ranges from $-22 \%$ to $-35 \%$, and average 
around $-27.8 \%$ (O'Leary, 1981). In the other two pathways $\left(\mathrm{C}_{4}\right.$ and $\left.\mathrm{CAM}\right)$, the oxygen insensitive PEPC (phosphoenolpyruvate carboxylase) fixes $\mathrm{CO}_{2}$, and malic acid is the first stable $\mathrm{C}_{4}$ product (Lüttge 2002; Ehleringer et al. 1991). This process reduces photorespiration and increases photosynthetic rates, improving nitrogen and water use efficiency (Hibberd et al. 2008; Langdale 2011). The measurable ${ }^{13} \mathrm{C}$ isotopic composition of plants with a $\mathrm{C}_{4}$ pathway - typical of monocotyledonean grasses and some trees and shrubs from warmer climates - ranges between $-10 \%$ and $-14 \%$, with an average around $-13.5 \%$ (Cerling et al. 1997; Keeley and Rundel 2003). The CAM pathway - found in succulents, such as cacti, members of orchids and bromeliads - has $\delta^{13} \mathrm{C}$ values between -10\%o and -35\% (Gröcke 1997; Ehleringer and Monson 1993). However, their distribution is limited and they play a minor role in the diet of large mammals, thus their presence or absence does not affect the carbon isotopic analyses. The measurable $\delta^{13} \mathrm{C}$ values of the bioapatite of extant large ruminant mammals are typically $14.1 \pm 0.5 \%$ higher than those of their forage plants (Cerling and Harris 1999), thus to infer information about the past diet of the animal, 14.1\%o was subtracted from the $\delta^{13} \mathrm{C}$ values measured from the apatite. $\mathrm{C}_{4}$ plants in Central Europe are rare compared to $\mathrm{C}_{3}$ plants (Pyankov et al. 2010). Based on this, no specimen with a specific $\mathrm{C}_{4}$ diet should be found, however the ratio between the $\mathrm{C}_{3}$ and $\mathrm{C}_{4}$ plants could have been different in past times, so some additional information can be extracted from these measurements. 


\section{Results}

\section{Dental mesowear analysis}

Mesowear analysis was conducted on 726 dental remains from 28 Pleistocene and Holocene localities. The average mesowear score for the Pleistocene and Holocene periods is 3.26 (Table 2, Figure 5).

From the early Pleistocene Osztramos 8, the teeth of nine Cervus sp. specimens were analyzed, with an average mesowear score of 1.44 . This score would classify the cervids from the early Pleistocene as browse-dominated mixed feeders (Table 2, Figure 5).

From the middle Pleistocene, 92 cervid dental elements were given a mesowear score, which had a mean of 2.33. Such a score would classify all middle Pleistocene cervids into the grass-dominated mixed feeder dietary category. The examined ten Alces specimens from Gombasek had an average score of 2.4, the nine Capreolus specimens from the same locality had a score of 3.67. The 64 Cervus specimens examined from Gombasek, Vértesszőlős II, Tarkő Rock-shelter, Vár Cave, Hórvölgy Rock-shelter and Uppony I had a mean score of 2.18. Furthermore six Dama specimens were examined from the locality of Üröm Hill with a mean mesowear score of 1. Two Megaloceros specimens were examined from Gombasek and Szuhogy-Csorbakő, with a mean value of 3. One Rangifer tarandus from Szuhogy-Csorbakő was also examined, its mesowear score was 6 (Table 2, Figure 5).

The mesowear scores of 601 cervids teeth were measured from 14 late Pleistocene localities. The average of the mesowear scores registered for this period was 3.43 . Based on this score, the typical cervid of the late Pleistocene was a grazer. In total, ten A. alces specimens were examined from Lambrecht Cave, Kiskevély Cave, Istállóskő Cave and Szelim Cave, their average mesowear score was 3.1. From Lambrecht Cave 
and Istállóskő Cave 14 C. capreolus teeth were scored, with an average of 1.99. Apart from that 27 C. elaphus specimens were also examined from the localities Lambrecht Cave, Kiskevély Cave, Tapolca Cave, Tokod-Nagyberek, Szelim Cave and Zebegény. The average mesowear score for these specimens was 3.85. Additionally, ten specimens of M. giganteus were examined from Lambrecht Cave, Tapolca Cave, TokodNagyberek and Zalaegerszeg, with a mean mesowear score of 3.7. Furthermore, a mesowear score was registered for $540 R$. tarandus specimens, with a mean value of 3.46 (Table 2, Figure 5).

Two localities, Berva-völgy Cave and Remete Cave were from the PleistoceneHolocene boundary. Eight cervid teeth were checked for their mesowear for this period, with a mean value of 2.5. Cervids based on this score would be classified into the grassdominated mixed feeder dietary category. Six C. elaphus were examined from the aforementioned two localities, their mean mesowear score was 2.5. Furthermore, two M. giganteus specimens were examined from Berva-völgy Cave, their average mesowear score was also 2.5 (Table 2, Figure 5).

From the Holocene, 16 cervid teeth from three localities, Petényi Cave, Baradla Cave and Kiskőhát Cave were used for mesowear analysis. The mean of these 16 scores was 3.94, classifying these cervids into the grazer category. Eleven C. elaphus specimens were examined from Petényi Cave and Baradla Cave, their mean mesowear score was 3.55. Additionally, five $R$. tarandus mesowear scores were registered with an average score of 4.79 (Table 2, Figure 5).

\section{Dental microwear analysis}

In total, 73 teeth were examined for microwear scars from 22 localities. The counted scratches and pits, as well as their standard deviation can be seen in Table 3 and plotted against the dietary morphospaces suggested by Solounias and Semprebon (2002) 
and Semprebon et al. (2004) on Figure 6. The average scratch count for all specimens was 20.14, ranging from 6 to 49. The average pit count for all specimens was 19.67, ranging from 3 to 46.

From the early Pleistocene Osztramos 8 locality, one Cervus specimen was analysed, its scratch count was 23.6 and its pit count was 19.2 (Table 3, Figure 5-6).

From the middle Pleistocene, twelve Cervus specimens were analysed from six localities (Gombasek, Vár Cave, Vértesszőlős II, Tarkő Rock-shelter, Uppony I and Hórvölgy Rock-shelter). The average number of scratches on the selected areas was 19.9, and the average number of pits on the same areas was 25.5. Furthermore, two Alces latifrons specimens were included from Gombasek, the average number of scratches on their teeth was 16.5, and the average number of pits was 15 . One Capreolus specimen was also examined from Gombasek, the average number of scratches on its teeth was 9.4, and the average number of pits was 30.6. From Üröm Hill, four Dama specimens were examined, with their dental microwear being an average of 16.4 scratches and 33.2 pits (Table 3, Figure 5-6).

From the late Pleistocene the microwear of in total 47 cervid specimens was quantified. Four A. alces specimens from Szelim Cave and Istállóskő Cave were examined with average scratch count being 17.2 and average pit count being 14.5. One C. capreolus specimen was also included from the Lambrecht Kálmán Cave, with 9 and 27 scratches and pits, respectively. Furthermore, eight $C$. elaphus specimens were analysed from Tapolca Cave, Kiskevély Cave, Lambrecht Kálmán Cave, Szelim Cave, Tokod-Nagyberek and Zebegény. The mean scratch and pit counts for said specimens were 26.9 and 15.1, respectively. Also eight M. giganteus specimens were examined from this period, from Tapolca Cave, Lambrecht Kálmán Cave, Tokod-Nagyberek and Zalaegerszeg. The average scratch count for these specimens was 24 , and the average 
pit count was 36.2 . In total, $26 R$. tarandus specimens were examined from this period, from Szelim Cave, Szeleta Cave, Ságvár, Peskő Cave, Jankovich Cave and Istállóskő Cave. These specimens had an average scratch count of 18.3, and an average pit count of 10.9 (Table 3, Figure 5-6).

From the Pleistocene-Holocene transition, the microwear of one M. giganteus specimen was examined from Berva-völgy Cave. The average number of scratches was 24.2, and the average number of pits was 31 (Table 3, Figure 5-6).

Five $C$. elaphus specimens were analysed from the Holocene period. The five specimens were from two localities, namely Petényi Cave and Baradla Cave. The average number of scratches on the teeth of the selected specimens was 23 , and the average number of pits was 21.5 (Table 3, Figure 5-6).

\section{Stable isotope analysis}

In total 28 phosphate, and 24 carbonate measurements were conducted. The results of the oxygen and carbon isotopic compositions of the examined samples, the calculated $\delta^{18} \mathrm{O}$ values for environmental water and the estimated paleotemperatures are given in Table 4. The test of diagenetic effects was done on those samples that had both phosphate and carbonate measurements. The majority of the enamel samples seem to be diagenetically unaltered, as most data points plot inside the $95 \%$ confidence interval of the $\delta^{18} \mathrm{O}_{\mathrm{CO} 3}-\delta^{18} \mathrm{O}_{\mathrm{PO} 4}$ regression calculated for modern cervids (Pellegrini et al. 2011) (Figure 7). Only one of the Üröm Hill Dama sp. specimens fell outside the confidence interval, marking that the results of that locality should further be treated with caution (Figure 7). The calculated environmental water $\delta^{18} \mathrm{O}$ values range from $-13.9 \%$ to $5.4 \%$, with a mean value of $9.5 \%$. The estimated palaeotemperature values for the Pleistocene range from $0.6{ }^{\circ} \mathrm{C}$ to $17.2{ }^{\circ} \mathrm{C}$, with a mean value of $9.2{ }^{\circ} \mathrm{C}$. Excluding the only diagenetically altered specimen from Üröm Hill decreased the mean Pleistocene 
temperature to $9.0{ }^{\circ} \mathrm{C}$. The measured $\delta^{13} \mathrm{C}$ values of the enamel samples ranged from $0.37 \%$ and $-11.75 \%$, which resulted in vegetation $\delta^{13} \mathrm{C}$ values ranging from $-14.47 \%$ o to $-25.85 \%$ (Figure 5).

From Gombasek, four diagenetically unaltered specimens of a Cervus species were analyzed. The $\delta^{18} \mathrm{O}_{\mathrm{PO} 4}$ values of the four specimens ranged from $13 \%$ o to $15.3 \%$, with a mean value of $14.3 \%$. The average of the calculated environmental water $\delta^{18} \mathrm{O}$ value and the mean annual temperature was $-9.58 \%$ and $8.99{ }^{\circ} \mathrm{C}$, respectively. From this locality, carbon isotopic composition could be measured on three specimens, with values ranging from $-9.7 \%$ to $-10.79 \%$, with an average value of $-10.09 \%$ (Table 4 , Figure 5).

From the locality of Üröm Hill, two Dama specimens were included in this study. From the two specimens, one was unaltered, the other one fell outside but close to the border of the confidence interval of the $\delta^{18} \mathrm{O}_{\mathrm{CO} 3}-\delta^{18} \mathrm{O}_{\mathrm{PO} 4}$ regression. The measurements based on this second specimen should be treated with caution. The $\delta^{18} \mathrm{O}_{\mathrm{PO} 4}$ values of the two specimens were $14.5 \%$ and $16.6 \%$. The average calculated environmental water $\delta^{18} \mathrm{O}$ value and the mean annual temperature was $-7.89 \%$ and $12.28{ }^{\circ} \mathrm{C}$ respectively. The measured carbon isotopic compositions were $-3.4 \%$ and $-6.06 \%$, with a mean value of $-4,73 \%$ (Table 4, Figure 5).

Vár Cave is represented by one Cervus cf. elaphus specimen with a $\delta^{18} \mathrm{O}_{\mathrm{PO} 4}$ value of $14.3 \%$. The calculated environmental water $\delta^{18} \mathrm{O}$ value based on this value was 9.58\%, which resulted in a mean annual temperature of $8.99{ }^{\circ} \mathrm{C}$ (Table 4, Figure 5).

From the Tarkő Rock-shelter, four unaltered Cervus acoronatus specimens were analysed. The $\delta^{18} \mathrm{O}_{\mathrm{PO} 4}$ values of the four specimens ranged from $13.2 \%$ to $15.9 \%$, with a mean value of $14.15 \%$. The average of the calculated environmental water $\delta^{18} \mathrm{O}$ value and the mean annual temperature was $-9.79 \%$ and $8.59{ }^{\circ} \mathrm{C}$, respectively. The $\delta^{13} \mathrm{C}$ value 
of the structural carbonate of the enamel of the examined specimens ranged from $8.43 \%$ to $-10.85 \%$, with a mean value of $-9.72 \%$ (Table 4 , Figure 5 ).

Four C. elaphus specimens were studied from Uppony I, these specimens were diagenetically unaltered. The range of the $\delta^{18} \mathrm{O}_{\mathrm{PO} 4}$ values were from $14.6 \%$ o to $17.3 \%$, with a mean value of $15.9 \%$. The average of the calculated environmental water $\delta^{18} \mathrm{O}$ value was $-7.42 \%$ and the mean annual temperature was $13.21^{\circ} \mathrm{C} . \delta 13 \mathrm{C}$ values were gained from three C. elaphus specimens from this locality, ranging from $-5.3 \%$ to 11,03\%o, with an average of $-7.74 \%$ (Table 4, Figure 5).

From the Lambrecht Cave, four C. elaphus specimens were included in this study. The $\delta^{18} \mathrm{O}_{\mathrm{PO} 4}$ values ranged from $13 \%$ to $17.4 \%$, with a mean value of $14.98 \%$. The mean $\delta^{18} \mathrm{O}$ of the calculated environmental water was $-8.67 \%$ and the mean annual temperature was $10.77^{\circ} \mathrm{C}$. The carbon isotopic composition of all four specimens could be measured as well, resulting in values ranging from $-9.63 \%$ to $-9.95 \%$, with a mean value of $-9,84 \%$ (Table 4, Figure 5).

Based on the diagenetic alteration test, the $R$. tarandus specimens from Szeleta Cave were unaltered. The $\delta^{18} \mathrm{O}_{\mathrm{PO} 4}$ values of the specimens were $12.1 \%$ and $14.8 \%$. The average calculated environmental water $\delta^{18} \mathrm{O}$ value and the mean annual temperature was $-10.73 \%$ and $6.75{ }^{\circ} \mathrm{C}$, respectively. One of the $\delta^{13} \mathrm{C}$ measurements had a notably higher value, and higher standard deviation compared to the others $(-0.37 \%)$. This value, which is shown on Figure 5, was treated here as an outlier, thus it was left out of further analyses. The other values were $-4.2 \%$ and $-11.75 \%$ (Table 4 , Figure 5).

Two M. giganteus and two C. elaphus specimens were analyzed from TokodNagyberek. Their $\delta^{18} \mathrm{O}_{\mathrm{PO} 4}$ values ranged from $11.1 \%$ to $14.8 \%$, with a mean value of $13.13 \%$. The mean $\delta^{18} \mathrm{O}$ of the calculated environmental water was $-11.17 \%$ and the mean annual temperature was $5.89^{\circ} \mathrm{C}$. One $M$. giganteus and one $C$. elaphus tooth was 
checked for carbon isotopic composition, their values were $-12.39 \%$ and $-9.07 \%$ o respectively (Table 4, Figure 5).

The youngest locality, Ságvár is represented by four supposedly unaltered Rangifer tarandus specimens. The $\delta^{18} \mathrm{O}_{\mathrm{PO} 4}$ values of the specimens ranged from $12.3 \%$ o to $14.6 \%$, with a mean of $13.53 \%$. The calculated mean $\delta^{18} \mathrm{O}$ of the environmental water was $-10.62 \%$, and the mean annual temperature was $6.97^{\circ} \mathrm{C}$. All four $R$. tarandus specimens were checked for ${ }^{13} \mathrm{C}$ composition, their values ranged from $-7.93 \%$ o to 10.46\%, their average $\delta^{13} \mathrm{C}$ value was $-9.38 \%$ (Table 4, Figure 5).

\section{Discussion}

\section{Dietary preferences}

Cervids are considered to be a generalist herbivore group, as they do not require strictly one or a few plant species, but rather forage on the available plants (e.g., Jenkins and Wright 1988; Launchbaugh and Urness 1992). However, this does not mean that different cervid species do not have preferred forage materials and are indistinguishable based on their diet. The mesowear and microwear analyses of the present study further support that different cervid species have different diets.

Elk, the largest extant cervid inhabits the northern parts of North America and Eurasia. As a rather cold-adapted species, its presence in southern regions is scarce. Elks are generally considered to be browsers, selecting foods with less fiber and high concentrations of nutrients (Renecker and Hudson 1990; Juntheikki 1996). The examined Pleistocene Alces specimens had mesowear scores characteristic of browseand grass-dominated mixed feeders (Figure 5), and their microwear suggested a browsing or an intermediate feeding type (Figure 6), which agrees with the results of the aforementioned literatures. 
Roe deers are small-bodied cervids, inhabiting most of Eurasia, except for the northernmost parts. They are considered to be browsers, feeding on buds and soft plant materials (Navarre 1993; Tixier and Duncan 1996). The microwear of the examined Capreolus specimens also showed this trait, as they occupied a small range in the browser dietary morphospace (Figure 6). The mesowear of most examined specimens also suggest a less abrasive diet, except for the Gombasek specimens (Figure 5).

Red deer is one of the most widespread cervids in Europe. The members of this taxon can survive in almost any kind of environment with sufficient forage materials. This could be due to the mixed feeder diet of the group (Renecker and Hudson 1990; Gebert and Verheyden-Tixier 2001). This mixed feeder trait was also marked in the present study, as Cervus specimens were found as grazers, browsers and intermediate feeders based on both their mesowear and microwear signals (Figure 5, Figure 6). In addition, whereas other examined cervids occupied only a smaller part of the dietary space, red deer not only spanned a much larger part of this morphospace, but changed its diet throughout the Pleistocene and Holocene based on the available forage plants, making this species extremely useful for paleoenvironmental reconstructions. Their mesowear score showed a gradual increase from the early to the late Pleistocene and Holocene. This gradual increase could have been associated with the opening of the vegetation as the climate got cooler, or with increased dust and grit intake of the more arid environments of the late Pleistocene. Based on their microwear, they mostly occupied the grazer and mixed feeder categories. When multiple deer species were present in the same locality, red deer had a microwear signal typical of grazers, possibly due to niche separation between different large herbivore species. As this species is considered to have a mixed diet, if other dietary niches are occupied, it can occupy any given dietary space. There is a slight difference between the diet of this species based 
on meso- and microwear analysis. This could be due to the possible bias of the microwear data towards specimens dying of during the seasons with higher mortality rates, during more stressful times of year (Young 1994; Gogarten et al. 2012; Taylor et al. 2016). On the other hand, mesowear represents the whole time period of an animal life, thus excludes this aforementioned bias (Mihlbachler 2018).

Fallow deer is a Eurasian deer species, with a present day native distribution restricted to the southern parts of Europe and the Middle East. Due to human activity, it was reintroduced to most of Europe. Fallow deer is considered to be a browser, with similar feeding habits as the roe deer (Jackson 1997; Nugent 1990). The examined Dama specimens from Üröm Hill also had a browsing diet based on both the mesowear and microwear analysis of the examined teeth (Figure 5, Figure 6).

Irish elk is one of the largest deer that ever lived. It roamed Eurasia throughout the Pleistocene. The diet of M. giganteus was diverse, based on its dental microwear, grazing, browsing and intermediate feeding also occurred as its feeding strategy (Rivals and Lister 2016). Based on plant macrofossil remains on the teeth of M. giganteus, it could have been a selective grazer, as most plant remains were from Artemisia, rich in calcium, necessary for the fast antler development of the species (Van Geel et al. 2018). The M. giganteus specimens of this paper based on their dental microwear also had a mixed feeder diet (Figure 6). Their mesowear however, spanned all dietary categories, from grazer to browser, suggesting that it could have had less strict dietary needs (Figure 5).

Reindeer, the cervid best adapted to cold environments, inhabit the northern regions of North America and Eurasia. They usually forage on less abrasive plant materials, ferns, mushrooms and lichens (Solounias et al. 1988; Kojola et al. 1998). The examined $R$. tarandus in this study had a dental mesowear characteristic of grazers, 
mostly with blunt teeth, with low apices (Figure 6). This could be either a result of a less optimal diet of the specimens, with more abrasive plants, or an increased amount of abrasive grit on the surface of the consumed plants (Kubo and Yamada 2014). This increased amount of grit could be due to a more open environment, where wind can easily pick up sand, loess, or other particles and contaminate the plants close to ground level, from where reindeer usually forage. These specimens occupy a smaller region in the microwear dietary morphospace, with low number of pits and intermediate to high number of scratches, also indicative of a relatively abrasive diet (Figure 5).

\section{Environmental implications}

\section{Early Pleistocene}

Osztramos 8 is the oldest of the examined localities, based on its recovered fauna, the material belongs to the Betfian stage (Jánossy and Kordos 1977; Jánossy 1972, 1986). The age of the locality is similar but slightly older than that of Osztramos 2 (Jánossy and Kordos 1977; Jánossy 1986). Based on the browse-dominated mixed feeder diet derived from the mesowear and the grazer diet derived from the microwear analysis of the examined Cervus sp. teeth, the surrounding vegetation of the locality was likely a mosaic forest-steppe, in which both soft and hard, abrasive plant material were available for the herbivores. Even though the sample sizes for the dental wear analyses are limited, the standard deviation of the results of the mesowear analysis is small. Thus, results based on these remains should be treated with caution, as it could be burdened with errors derived from the small sample size. This result corresponds well with the results of Pazonyi (2011), who developed ecological units for the Pleistocene of Hungary. According to her results, which were based on the synecological analysis of the fauna, this time period can be classified as a forest-steppe environment, with a low 
proportion of granivores, medium to low proportion of mixed feeders, carnivores, insectivores, and low proportion of grazers, as well as omnivores. A locality with similar age in Italy, the Pirro Nord complex supposedly had a moderately warm palaeoenvironment with mosaic woodlands as well (Pavia et al 2012).

\section{Middle Pleistocene}

The progression from the early to the middle Pleistocene was characterized by harsh cooling events. This interval is also called the Mid-Pleistocene Transition (MPT) (Berger and Jansen 1994; Mudelsee and Stattegger 1997). This was the period that saw the onset of the first important glaciations of the Pleistocene ranging from 1.2 Ma to 0.5 Ma (Head and Gibbard 2005). During this period, the presence of sub-tropical taxa was negligible in the Western Mediterranean region and based on palynological records the observed winter temperatures were about $5{ }^{\circ} \mathrm{C}$ colder than those of today (Joannin et al. 2011). Two of the examined localities were from this time interval, Gombasek and Üröm Hill, the former being slightly older than the latter.

At Gombasek several specimens from four genera (Alces, Capreolus, Cervus, Megaloceros) were present. Based on the environmental preferences of extant $C$. capreolus, the presence of roe deer in the site suggests that the vegetation had to be forested to some level. Furthermore the present day A. alces is found in colder environments, suggesting that the temperatures at this site had to be some degrees cooler. The mesowear signal of the examined specimens fell into the browse-dominated mixed feeder, the grass-dominated mixed feeder and the grazer dietary categories, suggesting that the environment of the period consisted of both open and closed vegetation. The lack of the clearly browsing specimens suggests that there were no extensive woodlands during this period. Interestingly, the examined Capreolus specimens fell into the grazer and the grass-dominated mixed feeder categories, which 
is unusual for recent Capreolus species are considered to be browsers, inhabiting woodlands (e.g., Solounias and Semprebon 2002; Merceron et al. 2004; Navarre 1993; Tixier and Duncan 1996). The microwear results of the specimens from this locality also suggest a mosaic environment, for all three main dietary categories (browser, grazer and mixed feeder) were present. There are two possibilities for this dental wear pattern: a) the examined specimens were of old age, so their mesowear pattern does not correlate with the diet, but rather is a result of their strongly eroded teeth, and their microwear reflects their actual diet. b) the mesowear of the specimens reflects the longterm effect of their diet on the teeth, indicating a suboptimal environment for Capreolus. The microwear on the other hand indicates a more optimal diet, which was available for shorter periods of time. Based on the dental wear stages, all animals belonged to the adult and late adult categories (Anders et al. 2011), so the second explanation seems to explain the observed phenomenon well. The reconstructed paleotemperature from this period was around $9{ }^{\circ} \mathrm{C}$, which is $2-3{ }^{\circ} \mathrm{C}$ lower than that of present day average temperatures of Hungary. This colder temperature correlates well with that of Joannin et al. (2011), who found $5^{\circ} \mathrm{C}$ difference between the past and present winter temperatures in the Mediterranean region. The average $\delta^{13} \mathrm{C}$ value for the examined specimens was $-10.09 \%$, which translates to a $-24.19 \%$ o $\delta^{13} \mathrm{C}$ value for their diet, which value is characteristic for the $C_{3}$ plants.

Six Dama specimens were studied from the Üröm Hill locality. The mesowear of these specimens classified them as browse-dominated mixed feeders, which suggests that a forest steppe environment with extensive woodlands was a possible vegetation type. The microwear of the studied specimens also classify them as browsers, further supporting the aforementioned vegetation. Again, due to the limited sample size, the derived conclusions should be treated with caution, even though their standard deviation 
is small, suggesting good results. Based on the fauna, the Üröm Hill locality could have been characterized by warm, humid climate and closed, forested vegetation with the dominance of dormice (Glis, Muscardinus) and forest voles (Myodes) (Virág and Pazonyi 2014). Similarly, a mosaic of open grassland and forest habitats and warm temperate conditions were reconstructed for the approximately coeval Voigtstedt locality (Central Germany) (Maul and Parfitt 2010). The calculated MAT of $12{ }^{\circ} \mathrm{C}$ seems extremely high compared to the value of $6{ }^{\circ} \mathrm{C}$ calculated by Virág (2013) based on stable isotopic measurements from a Mammuthus trogontherii molar from this locality. However, as mentioned in the results section, one of the two examined cervids could have been diagenetically altered (Figure 7). Excluding this specimen from the analysis alters the reconstructed MAT to $9{ }^{\circ} \mathrm{C}$. This decreases the difference between the two measurements, but a notable difference is still present. The two measurements were conducted in two independent laboratories (the cervids were examined in the Isotope Climatology and Environmental Research Centre, Institute for Nuclear Research, Debrecen, Hungary, meanwhile the M. trogontherii was examined in the University of Lausanne), which could cause slight differences between the measured values (see also Tütken et al. 2006). Furthermore, material from this locality could be from a large temporal range, so the examined specimens could have originated from cooler and warmer intervals of this period. The two taxa - one cervid and one proboscidean - are rather distant relatives, so there could be slight differences between the metabolisms of them. Their water and dietary necessities, and the operation of their digestive system could also differ, which could also explain such differences. Comparing the carbon isotopic composition of the aforementioned $M$. trogontherii (Virág 2013), and the examined cervids of this study, a significant difference can be seen between the two values, the former with a $\delta^{13} \mathrm{C}$ value of $-9.5 \%$ and the latter with 
an average $\delta^{13} \mathrm{C}$ value of $-4.73 \%$. (Virág and Pazonyi 2014). Excluding the possibly diagenetically altered specimen, the cervid $\delta^{13} \mathrm{C}$ value changes to $-6.06 \%$, which falls much closer to the data of Virág (2013). However, the data from the M. trogontherii should also be treated with caution, for that measurement could have been done on a diagenetically altered specimen (Virág 2013). The calculated $\delta^{13} \mathrm{C}$ value of the diet of the examined cervids suggests vegetation, which consists mainly of $\mathrm{C}_{3}$ and a few $\mathrm{C}_{4}$ plants. The latter can also be the result of a higher temperature, advantageous for the $\mathrm{C}_{4}$ metabolism (Pyankov et al. 2010).

During the relatively warm last interglacial of the Cromerian complex and the Holsteinian interglacial, the climate in general was similar to that of the present day (Pereira et al. 2018). The locality of Vértesszőlös II - on the basis of Arvicola mosbachensis, Stephanorhinus hundsheimensis and Cervus elaphus priscus -could be either from the MIS 13, or the MIS 11 interglacials (Van der Made 2010, 2012; Ruszkiczay-Rüdiger et al. 2018). During this period, the typical vegetation of the locality could have been a forest-steppe, or a warm steppe, with mild and humid winters and hot summers and autumns (Pazonyi 2011; Fitzsimmons et al. 2012). Our results based on C. elaphus specimens seem to support these aforementioned data, as based on their mesowear, the specimens had a grass-dominated mixed feeder diet, and the microwear of one specimen suggested that it had a grazer diet.

The MIS 11 climatic optimum was characterized by a relatively high sea surface temperature at the Mediterranean, at around $10-18{ }^{\circ} \mathrm{C}$ (Girone et al. 2013). The vegetation of the surrounding areas was more or less forested, as high arboreal pollen concentrations were recorded in the sediments of Lake Ohrid (Sadori et al. 2016). The Fortuna street sites from the Vár Cave locality fell into this timeframe based on the Arvicola cantiana-Lagurus transiens fauna of the site (Kordos 1994, 2004). The 
reconstructed MAT of $9{ }^{\circ} \mathrm{C}$ is based on only one specimen, however this temperature is relatively close to present day Central European temperatures. Based on the micro- and mesowear analyses, the three Cervus acoronatus specimens of the locality had a grassdominated mixed feeder diet. This agrees well with the presumed vegetation of the Carpathian Basin during this period, an open, mixed forest-steppe vegetation based on the vertebrate faunal composition of sites of this period (Pazonyi 2011).

From Marine Isotope Stage 9, the Saalian complex, the locality Tarkö Rockshelter (layers V-VII) was examined. The mesowear of three C. elaphus specimens was recorded, classifying the specimens into the grass-dominated mixed feeder category, suggesting an open parkland environment with forested patches. This higher mesowear index could either be the result of exogenous grit coating the surface of forage plant materials, or a more or less open environment of this period. The microwear of two specimens supports this open environment, as it classifies both specimens into the grazer dietary category. These results are also based on a limited sample, thus should be treated with caution and not taken for granted. Based on the fauna of the locality - the lack of steppe elements, and the dominance of open parkland elements - forest-steppe vegetation type was reconstructed by Pazonyi (2011). Similarly a relatively warm, but drier environment with open vegetation was suggested by Füköh et al. (1995) based on the gastropod fauna of the site. The reconstructed paleotemperature for this period was around $8.5{ }^{\circ} \mathrm{C}$, around $3-4{ }^{\circ} \mathrm{C}$ cooler than that of the present day Carpathian Basin. At such temperature, the presence of continuous forested vegetation could be limited and the dominance of grasses could have been more important. The average carbon isotopic composition of $-9.72 \%$ of the examined $C$. elaphus suggests a $\mathrm{C}_{3}$ plant dominated diet, further supporting the cooler temperatures and the open environment. 
The supposedly cool Marine Isotope Stage 8 is represented by the Hungarian locality, Szuhogy-Csorbakő from the end of this cold stage. Both the R. tarandus and the M. giganteus specimens from the locality had a high mesowear score, with an average of 5.5. This mesowear score suggests a grazer diet, or an increased intake of exogenous grit, both of which can be characteristic of open grassland and steppe vegetations, however, due to the limited sample size, this result should be treated with caution. Furthermore, the presence of $R$. tarandus also supports a colder, open environment. Pazonyi (2011) also reconstructed a cold steppe environment for this period for the Carpathian Basin. Similar results were reported by Bates et al. (2014) from the hominin bearing site Harnham, Wiltshire (Southern England) of the same age, with a wet grassland environment. Even though this locality is far from the Carpathian Basin, large scale processes seem to have had similar effects on both sites, which have a similar age and their reconstructed environment seems to support the aforementioned results.

Following up this colder period is the MIS 7 interglacial complex. The period could have been characterized mostly with typical forest environments throughout the South and Central European areas (López-García et al. 2014; Columbu et al. 2019). The subsequent MIS 6, on the other hand, was a glacial period with much cooler environments. Hórvölgy Rock-shelter and Uppony I are two localities with similar ages, also they are spatially close to each other. From the two, Hórvölgy Rock-shelter can be associated with the lowermost temporary range of Uppony I. However, the environment of the two sites seems to differ based on the results of both the mesowear and the microwear analysis. The C. elaphus specimens from Hórvölgy Rock-shelter had a browse-dominated mixed feeder diet based on their dental mesowear and a browser diet based on their microwear signal, both of which refer to a relatively forested vegetation. 
On the other hand, C. elaphus specimens from Uppony I were classified into the grazer dietary category based on their mesowear and to the mixed feeder category based on their microwear. This difference would suggest a shift in the environment around these localities, possibly due to the climate getting colder in the beginning of the MIS 6 stage. The remains from Hórvölgy Rock-shelter are from the end of the MIS 7 interglacial. This would explain that both the mesowear and microwear show a diet of mostly soft plant materials, typical of a forested environment. The results based on the remains from Uppony I, from MIS 6 would suggest a more open, arid environment, agreeing well with the results of Pazonyi (2011), who also found a mosaic forest-steppe environment for this period for the Carpathian Basin. The inferred environments for both sites are based on small samples, thus their reliability is debatable. The reconstructed MAT of Uppony $\mathrm{I}$, of $13{ }^{\circ} \mathrm{C}$ is about 1 to $2{ }^{\circ} \mathrm{C}$ higher than that of the average temperature of this area today. This higher temperature seems to contradict with the previous results, or the examined remains could be from the beginning of the cooling event, explaining the warmer reconstructed MAT. The carbon isotopic composition of the examined teeth suggest a $C_{3}$ or a mixed $C_{3}-C_{4}$ plant based diet, supporting the reconstructed high temperatures.

\section{Late Pleistocene and Holocene}

The oldest examined late Pleistocene locality was Lambrecht Kálmán Cave, which is from the transitional period between MIS 5 and MIS 4 stages. Mesowear analysis was conducted on the following species: A. alces, C. capreolus, C. elaphus and M. giganteus. The presence of the remains of several roe deer in the site suggests that the vegetation should have been forested to some extent, and the presence of $A$. alces suggests that the typical environment could have been somewhat cooler. The four cervid species covered most of the mesowear score range, C. capreolus and M. giganteus 
specimens had lower, whereas $A$. alces and C. elaphus specimens had higher mesowear scores. This wide range of observed mesowear scores suggests an environment, where multiple types of vegetation could be found, enabling a wide range of forage plants for the cervids to pick from. The microwear analysis of C. capreolus, C. elaphus and $M$. giganteus specimens seems to further support this diverse environment, for all three dietary categories were present based on this analysis. The examined $C$. capreolus showed a browser signal, $C$. elaphus a mostly grazer signal and M. giganteus showed traits of a mixed feeder. Based on the gastropod fauna of the site, Füköh et al. (1995) suggested that the sediment in the cave was formed during a slightly warmer period of Marine Isotope Stage 5a interglacial. The composition of the vertebrate fauna of the site suggests either an open mosaic woodland vegetation, or a transitional phase into the mammoth steppe vegetation (Pazonyi 2011). Based on our aforementioned results, the mosaic woodland vegetation seems more plausible. The stable isotopic analyses based on $C$. elaphus specimens suggest a reconstructed paleotemperature of about $10-11{ }^{\circ} \mathrm{C}$. This temperature is similar to, or slightly lower than that of the MAT of present day Hungary. Similar to that of modern MAT reconstructions were made based on the herpetofauna of the MIS 5/4 transitional site Cueva del Camino (Central Spain) (Blain et al. 2014). The carbon isotopic composition of the examined C. elaphus specimens suggests a diet composed of mainly $\mathrm{C}_{3}$ plants.

During the Würm glaciation, climate throughout Europe gradually got cooler, and harsher, until it reached its peak at the Last Glacial Maximum (LGM). From temperatures and environment similar to that of present day, it slowly shifted to more open, dry environments, with vegetations such as the mammoth steppe vegetation (Wachecka-Kotkowska et al. 2018). The remains from Kiskevély Cave are from the beginning of this cooling period, the locality spans mostly the MIS 4 stage. Based on 
the vertebrate faunal composition of the localities from the Carpathian Basin from this interval, consisting of a high density of grazers, and large and medium carnivores, and a low density of browser taxa, the typical vegetation of this period was most likely mammoth steppe (Pazonyi 2011). This seems to agree well with our results, as the examined $A$. alces and $C$. elaphus specimens had mesowear scores in the grazer and the grass-dominated mixed feeder category, characteristic of open vegetation and possibly increased amount of exogenous dirt and grit coating the surface of the available plant materials. The microwear of the examined specimens fell into the mixed feeder dietary category, close to the grazer category, which would also suggest that the vegetation could have been open, with some forest-patches.

Afterwards, apart from some minor warming events, mainly in MIS 3, the gradual cooling continues throughout MIS 4, MIS 3 and MIS 2 (Wachecka-Kotkowska et al. 2018). Tapolca Cave is a locality that represents this period, because it spans almost 25 thousand years. Remains from this locality could fall into the end of MIS 4, MIS 3, or the beginning of MIS 2. Overall, the typical vegetation of this period was most likely mammoth steppe (Pazonyi 2011). The examined C. elaphus and M. giganteus specimens seem to support this hypothesis, for the mesowear of these specimens fell into the grazer dietary category, which would be characteristic of a locality with cooler, arid environment and open vegetation.

Following up the previous group of localities, we enter the LGM. This was presumably the coldest period of the Pleistocene. From the Carpathian Basin, palynological and malacological data are widely available from this period. Malacological data suggest a mosaic tundra, and mesofil steppe vegetation in the eastern parts of the basin for the LGM (Sümegi 2005; Sümegi et al. 2012). In the late glacial, the lower parts of the basin were covered by a birch-pine forest-steppe 
vegetation (Sümegi et al. 2011). Based on pollen and plant macrofossil studies, this same area around 18 cal kyr BP was thought to be covered with a mosaic tundra vegetation, where trees and shrubs were represented by pine and birch, and on higher altitudes a steppe-tundra vegetation was present (Magyari et al. 2019). Around 16 cal kyr BP, this tundra vegetation was replaced by a cold conifer forest-steppe, and around 14 cal kyr BP a cold mixed forest-steppe vegetation appeared, which prevailed until the early Holocene (Magyari et al. 2019). The western parts of the basin had richer forest cover compared to the eastern parts (Juhász 2007; Molnár et al. 2013). The vegetation of these parts could have been similar to that of modern day boreal forest and tundra (Sümegi et al. 2008). In short, during the late pleniglacial (24-14.6 cal kyr BP) and the late glacial, the Carpathian Basin was covered by a partly forested vegetation, with birch and pine species being the dominant woody plants. On the lower parts of the basin an open, cold steppe vegetation was predominant (Magyari et al. 2014, 2019).

Four examined localities were from the beginning of this period, from the second half of MIS 2 and the beginning of MIS 1: Szeleta Cave, Tokod-Nagyberek I, Istállóskő Cave and Szelim Cave were examined. These localities could represent a transition from a cool environment into the LGM. The dominance of $R$. tarandus of all examined cervids suggests a cold, open environment. However, the presence of C. capreolus suggests that some sort of forest coverage was still present in the Basin. From these four localities, the mesowear of seven A. alces, one C. capreolus, five C. elaphus, two $M$. giganteus and $42 R$. tarandus specimens were registered. Overall, the average mesowear score of three species, C. elaphus, M. giganteus and R. tarandus classified them as grazers, and $A$. alces was classified as a grass-dominated mixed feeder. Only $C$. capreolus was classified as a browser, which agrees well with the dietary preference of extant roe deer. This predominance of grazers is characteristic for the supposed open 
mammoth steppe environment of this period, where wind easily carried dust and dirt and deposited them on the vegetation, increasing its abrasivity (Pazonyi 2011). The microwear of the examined specimens also suggests a mixed open environment, similar to the mesowear, where $A$. alces and $M$. giganteus foraged on a mixed diet, whereas $C$. elaphus and the dominant $R$. tarandus fed on more abrasive diet, as grazers or grassdominated mixed feeders. The reconstructed paleotemperatures from this period were around 6 and $7{ }^{\circ} \mathrm{C}$, around 4 to $6{ }^{\circ} \mathrm{C}$ cooler than that of present day Hungary. The ${ }^{13} \mathrm{C}$ composition of the examined cervid teeth suggest a $C_{3}$ plant based diet, characteristic of such a cool environment.

Seven of the examined localities fell entirely into the aforementioned coldest period of the LGM: Zebegény, Zalaegerszeg, Mogyorósbánya, Pilismarót, Ságvár, Jankovich Cave and Peskö Cave. For this period, the dominance of $R$. tarandus is even more conspicuous. The mesowear of every examined species fell into the grazer dietary category, and the microwear of the examined C. elaphus and R. tarandus specimens also fell into, or close to the grazer dietary morphospace. The results of both wear analyses strongly support an extremely open environment for this period. Two $M$. giganteus specimens fell into the mixed feeder category, suggesting that some tree or shrub cover should have still been present, creating an extremely open mixed vegetation. The MAT calculated for this period from $R$. tarandus specimens from Ságvár is around $7{ }^{\circ} \mathrm{C}$, still much cooler than that of present day Hungary. Furthermore, the low $\delta^{13} \mathrm{C}$ value, characteristic of a $\mathrm{C}_{3}$ plant diet, also supports this cool environment.

The transition from the Pleistocene to the Holocene could be characterized by an ever growing tree cover, with forest-steppe vegetation and in some places a warmsteppe vegetation (Magyari et al. 2010). At higher altitudes, temperate woodlands, and gallery forests were present with spruce (Nafrádi et al. 2013). These temperate 
woodlands prevailed until the Middle Holocene (Willis et al. 1997; Gardner 2002). Two of our localities were from this transitional period: Berva-völgy Cave and Remete Cave. The aforementioned warming, and the reforestation associated with it can also be observed on the wear of the cervid teeth as well. The previously dominant grazer mesowear signal is replaced by a grass-dominated mixed feeder signal in the C. elaphus and $M$. giganteus species as well. The microwear of the aforementioned M. giganteus also shows a mixed feeder diet.

During the Holocene, the gradual warming continued, with some minor cooling events. From 10.25 cal kyr BP, a temperate woodland forest steppe vegetation was reconstructed for the area, however the presence of spruce pollen suggests that cold mosaic-steppe vegetation was present as well (Magyari et al. 2010). Between 9.9 and 5.4 cal kyr BP, the climate was getting warmer and drier, resulting in an ever-growing presence of open temperate forest-steppe and steppe vegetations. In the northern parts of the basin, cold forest-steppe vegetation prevailed until around 6 cal kyr BP (Magyari et al. 2010; Nafrádi et al. 2013). Between 4.1 and 3.1 cal kyr BP, temperate forest-steppe vegetation was dominant, however, after $3.1 \mathrm{cal}$ kyr BP, a gradual deforestation could be observed due to the ever-growing presence of grazing livestock and agriculture (Magyari et al. 2010). Three examined localities from this period were Petényi Cave, Baradla Cave and Kiskőhát Cave. Despite this supposedly warmer period, the mesowear signal of the examined specimens showed a grazer diet. This, and the presence of $R$. tarandus in two of the three localities could suggest that the material examined could also include dental elements either from the short cooling events during the Holocene, or from the cold forest-steppe habitats prevailing until the Middle Holocene. The other explanation for this high mesowear score could be the increased dirt intake with the forage plants, which could be the result of an open vegetation, due to eolic 
transportation. The microwear of the examined C. elaphus however, shows that a wide variety of plant material was available during the examined period, as grazer, mixed feeder and browser signals can also be observed on their teeth.

\section{Conclusions}

In this study, we aimed to build a large-scale Pleistocene and Holocene paleoenvironmental reconstruction of the Carpathian Basin based on one of the most widespread herbivorous large mammal groups of said periods, the cervids. Dental elements of cervids are abundant in Pleistocene and Holocene localities, making them ideal for such analysis. To infer information about the past habitats in which the animals lived, three different taxon-free analyses were performed: dental mesowear analysis, dental microwear analysis and the analysis of the ${ }^{13} \mathrm{C}$ and ${ }^{18} \mathrm{O}$ isotope composition of structural carbonate and ${ }^{18} \mathrm{O}$ isotope composition of the phosphate of fossil bio-apatite from dental enamel. Well preserved cervid teeth were selected for these analyses from 27 Hungarian and one Slovakian sites.

Using the dental mesowear and microwear analyses, we attempted to reconstruct the past vegetation of the selected localities. The resolution of these methods is low, some information can be gained regarding the openness of the vegetation and regarding the presence or absence of multiple dietary categories, indicating the complexity of the biome. Both the mesowear and microwear analysis seems to give a good representation about the past environments. Colder periods were represented by higher mesowear scores, indicating grass-dominated mixed feeders and grazers, and a microwear signal representing mostly grazers. This pattern suggests a more open vegetation type for the cooler periods in the Carpathian Basin. Furthermore, during these cool periods grazers and grass-dominated mixed feeders were dominant and the other dietary categories seemed to be scarce. On the other hand, during the presumably warmer periods, the 
dietary pattern shifted from grass-dominated, to mixed feeders and browsers, indicating increased tree cover. The complexity of vegetation could also have increased, for during these periods almost every dietary category was present. This agrees well with earlier results of this area based on other vertebrate groups, plant macrofossils, pollens and gastropods.

After checking for diagenetic alteration, the isotopic composition of samples suitable for paleoenvironmental interpretations were further analysed. An MAT was estimated using tooth enamel $\delta^{18} \mathrm{O}_{\mathrm{PO} 4}$ for nine Pleistocene localities. These estimated temperatures seem to follow the global temperature changes well. For glacial periods, the estimated temperatures are about $5-6{ }^{\circ} \mathrm{C}$ cooler than that of present day Hungary, and for the interglacial warm periods, temperatures similar to modern Hungary were inferred. The $\delta^{13} \mathrm{C}$ values of the examined cervids suggest a mainly $\mathrm{C}_{3}$ plant based vegetation (woodland, mesic $\mathrm{C}_{3}$ grassland), which agrees with the fact that $\mathrm{C}_{4}$ plants are scarcer in colder environments.

\section{Acknowledgements}

We would like to thank Mihály Gasparik from the Vertebrate Paleontological Collection of the Hungarian Natural History Museum (Budapest), Gábor Csorba and Tamás Görföl from the Mammalia Collection of the Hungarian Natural History Museum (Budapest), László Makádi from the Mining and Geological Survey of Hungary (Budapest) and Annamária Bárány from the Archaeozoological Collection of the Hungarian National Museum (Budapest) for their help in gathering and letting us access to the examined materials and the comparative material necessary for the preparation of this paper. The staff of the Department of Paleontology at the Eötvös Loránd University is also acknowledged for the help and infrastructure they provided. Furthermore, we would like to thank the reviewers for their useful and constructive 
comments and corrections of the manuscript. The research was supported by the European Union and Hungary, co-financed by the European Regional Development Fund through the GINOP-2.3.2-15-2016-00009 'ICER' project. This paper is MTAMTM-ELTE Paleo contribution No. 337.

\section{Declaration of interest statement}

The authors declare that they have no known competing financial interests or personal relationships that could have appeared to influence the work reported in this paper.

\section{References}

Adams B. 2002. New radiocarbon dates from Szeleta and Istállós-kő caves, Hungary. Praehistoria. 3:53-55.

Alexander GL, Segiura T. 1990. Pasture dry matter and drinking water intake of grazing red deer stags and steers. Proceedings of the New Zealand Society of Animal Production. 50:55-58.

Anders U, von Koenigswald W, Ruf I, Smith BH. 2011. Generalized individual dental age stages for fossil and extant placental mammals. Paläontologische Zeitschrift. 85(3):321-339.

Bassett D, Macleod KG, Miller JF, Ethington RL. 2007. “Oxygen Isotopic Composition of Biogenic Phosphate and the Temperature of Early Ordovician Seawater." Palaios. 22(1):98-103.

Bates MR, Wenban-Smith FF, Bello SM, Bridgland DR, Buck LT, Collins MJ, Keen DH, Leary J, Parfitt SA, Penkman K, et al. 2014. Late persistence of the Acheulian in southern Britain in an MIS 8 interstadial: evidence from Harnham, Wiltshire. Quaternary Science Reviews. 101:159-176.

Berger WH, Bickert T, Jansen E, Wefer G, Yasuda M. 1993. The central mystery of the Quaternary ice age: a view from the South Pacific. Oceanus. 36(4):53-57. 
Berger WH, Jansen E. 1994. Mid-Pleistocene climate shift-the Nansen connection. GMS. 85:295-311.

Blain HA, Laplana C, Sevilla P, Arsuaga JL, Baquedano E, Pérez-González A. 2014. MIS 5/4 transition in a mountain environment: herpetofaunal assemblages from Cueva del Camino, central Spain. Boreas. 43(1):107-120.

Bösken J, Sümegi P, Zeeden C, Klasen N, Gulyás S, Lehmkuhl F. 2018. Investigating the last glacial Gravettian site 'Ságvár Lyukas Hill'(Hungary) and its paleoenvironmental and geochronological context using a multi-proxy approach. Palaeogeography, Palaeoclimatology, Palaeoecology. 509:77-90.

Bradák B, Markó A. 2006. A Szelim-barlang (Tatabánya) üledéksorának vizsgálata és fejlődéstörténetének vázlata. Földtani Közlöny. 136(2):233-248.

Bryant JD, Froelich PN. 1995. A model of oxygen isotope fractionation in body water of large mammals. Geochimica et Cosmochimica Acta. 59(21):4523-4537.

Cerling TE, Harris JM, Ambrose SH, Leakey MG, Solounias N. 1997. Dietary and environmental reconstruction with stable isotope analyses of herbivore tooth enamel from the Miocene locality of Fort Ternan, Kenya. Journal of Human Evolution. 33(6):635-650.

Cerling TE, Harris JM. 1999. Carbon isotope fractionation between diet and bioapatite in ungulate mammals and implications for ecological and paleoecological studies.

Oecologia. 120(3):347-363.

Columbu A, Spötl C, De Waele J, Yu TL, Shen CC, Gázquez F. 2019. A long record of MIS 7 and MIS 5 climate and environment from a western Mediterranean speleothem (SW Sardinia, Italy). Quaternary Science Reviews. 220:230-243.

Dansgaard W. 1964. Stable isotopes in precipitation. Tellus. 16(4):436-468.

Davies W, Hedges REM. 2008. Dating a type site: Fitting Szeleta cave into its regional chronometric context. Praehistoria. 9:35-45.

Dawson TE, Mambelli S, Plamboeck AH, Templer PH., Tu KP. 2002. Stable isotopes in plant ecology. Annual review of ecology and systematics. 33(1):507-559. 
D'Angela D, Longinelli A. 1990. Oxygen isotopes in living mammal's bone phosphate: further results. Chemical Geology: Isotope Geoscience Section. 86(1):75-82.

Dobosi VT. 2016. Tradition and modernity in the lithic assemblage of Mogyorósbánya Late Palaeolithic site. Acta Archaeologica Academiae Scientiarum Hungaricae. 67(1):5-30.

Dobosi VT, Vörös I. 1994. Material and chronological revision of the Kiskevély Cave. Folia archaeologica. 43:9-50.

Ehleringer JR, Monson RK. 1993. Evolutionary and ecological aspects of photosynthetic pathway variation. Annual Review of Ecology and Systematics. 24(1):411-439.

Ehleringer JR, Sage RF, Flanagan LB, Pearcy RW. 1991. Climate change and the evolution of C4 photosynthesis. Trends in ecology and evolution. 6(3):95-99.

Evans DL, Freeland HJ, Hays JD, Imbrie J, Shackleton NJ. 1977. Variations in the Earth's orbit: Pacemaker of the ice ages?. Science. 198(4316):528-530.

Faure M, Guérin C. 1992. La grande faune d'Europe occidentale au Pléistocène moyen et supérieur et ses potentialités d'information en préhistoire. Mémoires de la Société géologique de France (1833). 160:77-83.

Faure H, Walter RC, Grant DR. 2002. The coastal oasis: ice age springs on emerged continental shelves. Global and Planetary Change. 33(1-2):47-56.

Fitzsimmons KE, Marković SB, Hambach U. 2012. Pleistocene environmental dynamics recorded in the loess of the middle and lower Danube basin. Quaternary Science Reviews. 41:104-118.

Fortelius M, Solounias N. 2000. Functional characterization of ungulate molars using the abrasion-attrition wear gradient: A new method for reconstructing palaeodiets. American Museum Novitates. 225:1-36.

Fricke HC, Clyde WC, O’Neil JR. 1998. Intra-tooth variations in $\delta 180$ (PO4) of mammalian tooth enamel as a record of seasonal variations in continental climate variables. Geochimica et Cosmochimica Acta. 62(11):1839-1850. 
Füköh L, Krolopp E, Sümegi P. 1995. Quaternary malacostratigraphy in Hungary (Vol. 1). Natural Science Section of Mátra Museum.

Gardner AR. 2002. Neolithic to Copper Age woodland impacts in northeast Hungary? Evidence from the pollen and sediment chemistry records. The Holocene. 12(5):541553.

Garvie-Lok SJ, Varney TL, Katzenberg AM. 2004. Preparation of bone carbonate for stable isotope analysis: The effects of treatment time and acid concentration. Journal of Archaeological Science. 31 (6):763-76.

Gasparik M. 1993. Late Pleistocene gastropod and vertebrate fauna from Tokod (NE Transdanubia, Hungary). Fragmenta Mineralogica et Palaeontologica. 16(89):e116.

Gasparik M, Wagner J. 2014. Research history of Pleistocene faunas in Gombasek quarry (Slovakia), with comments to the type specimen and the type locality of Ursus deningeri gombaszogensis Kretzoi, 1938. Fragmenta Palaeontologica Hungarica. 31:125-143.

Gábori M. 1976. Les civilisations du paléolithique moyen entre les Alpes et l'Oural: esquisse historique. Akadémiai Kiadó.

Gebert C, Verheyden-Tixier H. 2001. Variations of diet composition of red deer (Cervus elaphus L.) in Europe. Mammal Review. 31(3-4):189-201.

Girone A, Maiorano P, Marino M, Kucera M. 2013. Calcareous plankton response to orbital and millennial-scale climate changes across the Middle Pleistocene in the western Mediterranean. Palaeogeography, Palaeoclimatology, Palaeoecology. 392:105116.

Grine FE. 1986. Dental evidence for dietary differences in Australopithecus and Paranthropus: a quantitative analysis of permanent molar microwear. J Hum Evol. 15:783-822.

Gogarten JF, Brown LM, Chapman CA, Cords M, Doran-Sheehy D, Fedigan LM, Grine FE, Perry S, Pusey AE, Sterck EHM, et al. 2012. Seasonal mortality patterns in non-human primates: Implications for variation in selection pressures across 
environments. Evolution: International Journal of Organic Evolution. 66(10):32523266.

Gröcke DR. 1997. Stable-isotope studies on the collagenic and hydroxylapatite components of fossils: Palaeoecological implications. Lethaia. 30(1):65-78.

Haiduc BS, Răţoi BG, Semprebon, GM. 2018. Dietary reconstruction of PlioPleistocene proboscideans from the Carpathian Basin of Romania using enamel microwear. Quaternary International. 467:222-229.

Head MJ, Gibbard PL. 2005. Early-Middle Pleistocene transitions: an overview and recommendation for the defining boundary. Geological Society, London, Special Publications. 247(1):1-18.

Hellebrandt M, Kordos L, Tóth L. 1976. A Diósgyőr-Tapolca-barlang ásatásának eredményei. A Herman Ottó Múzeum Évkönyve. 15:7-36.

Henton E, Martin L, Garrard A, Jourdan AL, Thirlwall M, Boles O. 2017. Gazelle seasonal mobility in the Jordanian steppe: The use of dental isotopes and microwear as environmental markers, applied to Epipalaeolithic Kharaneh IV. Journal of Archaeological Science: Reports. 11:147-158.

Hibberd JM, Sheehy JE, Langdale JA. 2008. Using C4 photosynthesis to increase the yield of rice—rationale and feasibility. Current Opinion in Plant Biology. 11(2):228231.

Huybrechts P. 2002. Sea-level changes at the LGM from ice-dynamic reconstructions of the Greenland and Antarctic ice sheets during the glacial cycles. Quaternary Science Reviews. 21(1-3):203-231.

Iacumin P, Longinelli A. 2002. Relationship between $\delta 180$ values for skeletal apatite from reindeer and foxes and yearly mean $\delta 180$ values of environmental water. Earth and Planetary Science Letters. 201(1):213-219.

Jackson J. 1997. The annual diet of the fallow deer (Dama dama) in the New Forest, Hampshire, as determined by rumen content analysis. Journal of Zoology. 181(4):465473. 
Jánossy D. 1972. Ein kleiner Hystrix aus dem Altpleistozaen der fundstelle Osztramos 8. (Nordungarn). Vertebrata Hungarica. 13:163-182.

Jánossy D. 1986. Pleistocene vertebrate faunas of Hungary. Elsevier.

Jánossy D, Krolopp E, Brunnacker K. 1968. Die Felsnische Uppony I (Nordungarn). Eiszeitalter und Gegenwart. 19(1):31-47.

Jánossy D, Kordos L. 1977. Az Osztromos gerinces lelőhelyeinek faunisztikai és karsztmorfológiai áttekintése. Fragmenta Minerologica et Palaeontologica. 8:39-72.

Jánossy D, Vörös I. 1985. „Revision der mittelpleistozänen Säugetierfauna des „Felsdaches” Szuhogy-Csorbakő (Nordungarn)”. In Annales historico-naturales Musei nationalis hungarici. 77:69-95.

Jenkins KJ, Wright RG. 1988. Resource partitioning and competition among cervids in the northern Rocky Mountains. Journal of Applied Ecology. 25(1):11-24.

Joannin S, Bassinot F, Nebout NC, Peyron O, Beaudouin C. 2011. Vegetation response to obliquity and precession forcing during the Mid-Pleistocene Transition in Western Mediterranean region (ODP site 976). Quaternary Science Reviews. 30(3-4):280-297.

Juhász I. 2007. Comparison and correlation of four pollen sequences from the Little Balaton region (Alsópahok, Fónyed, Keszthely, Zalavar). Environmental Archaeology in Transdanubia. Archaeological Institute of the Hungarian Academy of Sciences, Budapest. 36-51.

Juntheikki MR. 1996. Comparison of tannin-binding proteins in saliva of Scandinavian and North American moose (Alces alces). Biochemical Systematics and Ecology. 24(78):595-601.

Kaiser TM, Fortelius M. 2003. Differential mesowear in occluding upper and lower molars: Opening mesowear analysis for lower molars and premolars in hypsodont horses. Journal of Morphology. 258:67-83.

Kaiser TM, Solounias N. 2003. Extending the tooth mesowear method to extinct and extant equids. Geodiversitas. 25:321-345. 
Keeley JE, Rundel PW. 2003. Evolution of CAM and C4 carbon-concentrating mechanisms. International Journal of Plant Sciences. 164(S3):55-77.

Kohn MJ. 2010. Carbon isotope compositions of terrestrial C3 plants as indicators of (paleo) ecology and (paleo) climate. Proceedings of the National Academy of Sciences. 107(46):19691-19695.

Kohn MJ, Schoeninger MJ, Barker WW. 1999. Altered states: effects of diagenesis on fossil tooth chemistry. Geochimica et cosmochimica acta. 63(18):2737-2747.

Kojola I, Helle T, Huhta E, Niva A. 1998. Foraging conditions, tooth wear and herbivore body reserves: a study of female reindeer. Oecologia. 117(1-2):26-30.

Kordos L. 1981. „A magyarországi holocén képződmények gerinces-faunafejlődése, biosztratigráfiája és paleoökológiája”. Kandidátusi értekezés, Budapest.

Kordos L. 1991. A közép-európai felsy-pleisztocén pocokfauna fejlydése és biosztratigráfiai értékelése [Evolution and Biostratigraphic Ranging of the Late Pleistocene Vole Fauna in Central Europe]. A Magyar Állami Földtani Intézet Évi Jelentése az 1989. évröl. 495-522.

Kordos L. 1994. Revised biostratigraphy of the early man site at Vértesszőlös, Hungary. Courier Forschungs-Institut Senckenberg. 171:225-236.

Kordos L. 2004. Stratigraphy of the Middle Pleistocene „Buda Culture” of the Castle Hill of Buda, Hungary. Praehistoria. 4-5:9-32.

Kovács J. 2012. Radiocarbon chronology of Late Pleistocene large mammal faunas from the Pannonian basin (Hungary). Bulletin of Geosciences. 87(1):13-19.

Kovács J, Moravcová M, Újvári G, Pintér AG. 2012. Reconstructing the paleoenvironment of East Central Europe in the Late Pleistocene using the oxygen and carbon isotopic signal of tooth in large mammal remains. Quaternary International. 276:145-154.

Kovács J, Szabó P, Kocsis L, Vennemann T, Sabol M, Gasparik M, Virág A. 2015. Pliocene and Early Pleistocene paleoenvironmental conditions in the Pannonian Basin 
(Hungary, Slovakia): Stable isotope analyses of fossil proboscidean and perissodactyl teeth. Palaeogeography, Palaeoclimatology, Palaeoecology. 440:455-466.

Kubo MO, Yamada E. 2014. The inter-relationship between dietary and environmental properties and tooth wear: comparisons of mesowear, molar wear rate, and hypsodonty index of extant sika deer populations. PloS One. 9(3):e90745.

Langdale JA. 2011. C4 cycles: past, present, and future research on C4 photosynthesis. The Plant Cell. 23(11):3879-3892.

Launchbaugh KL, Urness PJ. 1992. Mushroom consumption (mycophagy) by North American cervids. The Great Basin Naturalist. 52(4):321-327.

Lisiecki LE, Raymo ME. 2005. A Pliocene-Pleistocene stack of 57 globally distributed benthic $\delta 180$ records. Paleoceanography. 20(1):PA1003.

Longinelli A. 1984. Oxygen isotopes in mammal bone phosphate: a new tool for paleohydrological and paleoclimatological research?. Geochimica et cosmochimica Acta. 48(2):385-390.

López-García JM, Blain HA, Julià R, Maroto J. 2014. Environment and climate during MIS 7 and their implications for the late Middle Pleistocene hominins: The contribution of Mollet cave, Serinyà, Girona, northeastern Iberian Peninsula. Quaternary International. 337:4-10.

Ludbrook J. 2010. Linear regression analysis for comparing two measurers or methods of measurement: but which regression?. Clinical and Experimental Pharmacology and Physiology. 37(7):692-699.

Luz B, Kolodny Y, Horowitz M. 1984. Fractionation of oxygen isotopes between mammalian bone-phosphate and environmental drinking water. Geochimica et Cosmochimica Acta. 48(8):1689-1693.

Luz B, Kolodny Y. 1985. Oxygen isotope variations in phosphate of biogenic apatites, IV. Mammal teeth and bones. Earth and planetary science letters. 75(1):29-36. 
Luzi E, Pazonyi P, López-García JM. 2019. The influence of climate on morphometric traits of fossil populations of Microtus arvalis and M. agrestis from the Carpathian Basin, northern Hungary. Lethaia. 52(1):123-132.

Lüttge U. 2002. CO2-concentrating: consequences in crassulacean acid metabolism. Journal of Experimental Botany. 53(378):2131-2142.

Magyari EK, Chapman JC, Passmore DG, Allen JRM, Huntley JP, Huntley B. 2010. Holocene persistence of wooded steppe in the Great Hungarian Plain. Journal of Biogeography. 37(5):915-935.

Magyari EK, Kuneš P, Jakab G, Sümegi P, Pelánková B, Schäbitz F, Braun M, Chytrý M. 2014. Late Pleniglacial vegetation in eastern-central Europe: are there modern analogues in Siberia?. Quaternary Science Reviews. 95:60-79.

Magyari EK, Pál I, Vincze I, Veres D, Jakab G, Braun M, Szalai Z, Szabó Z, Korponai J. 2019. Warm Younger Dryas summers and early late glacial spread of temperate deciduous trees in the Pannonian Basin during the last glacial termination (20-9 kyr cal BP). Quaternary Science Reviews. 225:105980.

Markó A. 2009. Raw material circulation during the Middle Palaeolithic period in northern Hungary. Surowce naturalne w Karpatach oraz ich wykorzystanie w pradziejach i wczesnym sredniowieczu. 107-119.

Markó A. 2013. On the Middle Palaeolithic industry of the Jankovich cave (northeastern Transdanubia). Archaeologiai Értesítő. 138(1):7-28.

Martin C, Bentaleb I, Kaandorp R, Iacumin P, Chatri K. 2008. Intra-tooth study of modern rhinoceros enamel $\delta 180$ : Is the difference between phosphate and carbonate $\delta 180$ a sound diagenetic test?. Palaeogeography, Palaeoclimatology, Palaeoecology. 266(3-4):183-189.

Maul LC, Parfitt SA. 2010. Micromammals from the 1995 Mammoth Excavation at West Runton, Norfolk, UK: Morphometric data, biostratigraphy and taxonomic reappraisal. Quaternary international. 228(1-2):91-115. 
Merceron G, Viriot L, Blondel C. 2004. Tooth microwear pattern in roe deer (Capreolus capreolus L.) from Chizé (Western France) and relation to food composition. Small Ruminant Research. 53(1-2):125-132.

Mészáros LG. 2004. Taxonomical revision of the Late Würm Sorex (Mammalia, Insectivora) remains of Hungary, for proving the presence of an alpine ecotype in the Pilisszántó Horizon. In Annales Universitatis Scientiarum Budapestinensis, Sectio Geologica. 34:9-25.

Mihlbachler MC, Campbell D, Chen C, Ayoub M, Kaur P. 2018. Microwear-mesowear congruence and mortality bias in rhinoceros mass-death assemblages. Paleobiology. 44(1):131-154.

Mihlbachler MC, Rivals F, Solounias N, Semprebon GM. 2011. Dietary Change and Evolution of Horses in North America. Science. 331:1178-1181.

Molnár M, Czobel S, Medzihradszky Z, Barczi A. 2013. Pleisztocén-holocén vegetáció a fejér megyei Sárrét területén (The vegetation of the Sárrét basin of Fejér county in the late-Pleistocene and Holocene). Tájökológiai Lapok. 11(2):321-324.

Mudelsee M, Stattegger K. 1997. Exploring the structure of the mid-Pleistocene revolution with advanced methods of time-series analysis. Geologische Rundschau. 86(2):499-511.

Náfrádi K, Jakab G, Sümegi P, Szelepcsényi Z. 2013. Future climate impacts in woodland and forest steppe based on Holocene paleoclimatic trends, paleobotanical change in central part of the Carpathian Basin (Hungary). American Journal of Plant Sciences. 4(6):1187-1203.

Navarre PR. 1993. Contribution à l'étude d'une population de chevreuils (Capreolus capreolus L.) en forêt d'Ibos (Hautes-Pyrénées): alimentation, biometrie et reproduction. (Doctoral dissertation).

Nugent G. 1990. Forage availability and the diet of fallow deer (Dama dama) in the Blue Mountains, Otago. New Zealand journal of ecology. 13(1):83-95. 
O'Leary MH. 1981. Carbon isotope fractionation in plants. Phytochemistry. 20(4):553567.

Passey BH, Robinson TF, Ayliffe LK, Cerling TE, Sponheimer M, Dearing MD, Roeder BL, Ehleringer JR. 2005. Carbon isotope fractionation between diet, breath $\mathrm{CO} 2$, and bioapatite in different mammals. Journal of Archaeological Science. 32(10):1459-1470.

Pavia M, Zunino M, Coltorti M, Angelone C, Arzarello M, Bagnus C, Bellucci L, Colombero S, Marcolini F, Peretto C, et al. 2012. Stratigraphical and palaeontological data from the Early Pleistocene Pirro 10 site of Pirro Nord (Puglia, south eastern Italy). Quaternary International. 267:40-55.

Pazonyi P. 2004. Mammalian ecosystem dynamics in the Carpathian Basin during the last 27,000 years. Palaeogeography, Palaeoclimatology, Palaeoecology. 212(3-4):295314.

Pazonyi P. 2011. Palaeoecology of Late Pliocene and Quaternary mammalian communities in the Carpathian Basin. Acta Zoologica Cracoviensia-Series A: Vertebrata. 54(1-2):1-32.

Pellegrini M, Lee-Thorp JA, Donahue RE. 2011. Exploring the variation of the $\delta 18 \mathrm{Op}$ and $\delta 180 \mathrm{c}$ relationship in enamel increments. Palaeogeography, Palaeoclimatology, Palaeoecology. 310(1-2):71-83.

Pereira A, Nomade S, Moncel MH, Voinchet P, Bahain JJ, Biddittu I, Falguères C, Giaccio B, Manzi G, Parenti F, et al. 2018. Integrated geochronology of Acheulian sites from the southern Latium (central Italy): Insights on human-environment interaction and the technological innovations during the MIS 11-MIS 10 period. Quaternary Science Reviews. 187:112-129.

Pushkina D, Bocherens H, Ziegler R. 2014. Unexpected palaeoecological features of the Middle and Late Pleistocene large herbivores in southwestern Germany revealed by stable isotopic abundances in tooth enamel. Quaternary International. 339:164-178. 
Pyankov VI, Ziegler H, Akhani H, Deigele C, Luettge U. 2010. European plants with C4 photosynthesis: geographical and taxonomic distribution and relations to climate parameters. Botanical Journal of the Linnean Society. 163(3):283-304.

Renecker LA, Hudson RJ. 1990. Digestive kinetics of moose (Alces alces), wapiti (Cervus elaphus) and cattle. Animal Science. 50(1):51-61.

Ringer Á. 2002. The new image of Szeleta and Istállós-kő caves in the Bükk Mountains: a revision project between 1999-2002. Praehistoria. 3:47-52.

Ringer Á, Moncel MH. 2002. Le Taubachien dans la Grotte Diósgyőr-Tapolca (Montagne de Bükk. Hongrie du Nord-est."Praehistoria. 3:177-201.

Rivals F, Solounias N. 2007. Differences in tooth microwear of populations of caribou (Rangifer tarandus, Ruminantia, Mammalia) and implications to ecology, migration, glaciations and dental evolution. J. Mamm. Evol. 14:182-192.

Rivals F, Julien MA, Kuitems M, Van Kolfschoten T, Serangeli J, Drucker DG, Bocherens H, Conard NJ. 2015. Investigation of equid paleodiet from Schöningen 13 II4 through dental wear and isotopic analyses: Archaeological implications. Journal of Human Evolution. 89:129-137.

Rivals F, Lister AM. 2016. Dietary flexibility and niche partitioning of large herbivores through the Pleistocene of Britain. Quaternary Science Reviews. 146:116-133.

Rivals F, Semprebon GM. 2017. Latitude matters: an examination of behavioural plasticity in dietary traits amongst extant and Pleistocene Rangifer tarandus. Boreas. 46(2):254-263.

Ruszkiczay-Rüdiger Z, Csillag G, Fodor L, Braucher R, Novothny Á, Thamó-Bozsó E, and ASTER Team. 2018. Integration of new and revised chronological data to constrain the terrace evolution of the Danube River (Gerecse Hills, Pannonian Basin). Quaternary Geochronology. 48:148-170.

Saarinen J, Karme A. 2017. Tooth wear and diets of extant and fossil xenarthrans (Mammalia, Xenarthra) - Applying a new mesowear approach. Palaeogeography, Palaeoclimatology, Palaeoecology. 476:42-54. 
Saarinen J, Lister AM. 2016. Dental mesowear reflects local vegetation and niche separation in Pleistocene proboscideans from Britain. Journal of Quaternary Science. 31:799-808.

Sadori L, Koutsodendris A, Panagiotopoulos K, Masi A, Bertini A, CombourieuNebout N, Francke A, Kouli K, Joannin S, Mercuri AM, et al. 2016. Pollen-based paleoenvironmental and paleoclimatic change at Lake Ohrid (south-eastern Europe) during the past $500 \mathrm{ka}$. Biogeosciences. 13(5):1423-1437.

Sánchez-Hernández C, Rivals F, Blasco R, Rosell J. 2016. Tale of two timescales: Combining tooth wear methods with different temporal resolutions to detect seasonality of Palaeolithic hominin occupational patterns. Journal of Archaeological Science: Reports. 6:790-797.

Semprebon GM, Godfrey LR, Solounias N, Sutherland MR, Jungers WL. 2004. Can low-magnification stereomicroscopy reveal diet? J. Hum. Evol. 47:115-144.

Semprebon GM, Tao D, Hasjanova J, Solounias N. 2016. An examination of the dietary habits of Platybelodon grangeri from the Linxia Basin of China: Evidence from dental microwear of molar teeth and tusks. Palaeogeography, Palaeoclimatology, Palaeoecology. 457:109-116.

Skinner HCW. 2005. Biominerals. Mineralogical Magazine. 69(5): 621-641.

Smith RJ. 2009. Use and misuse of the reduced major axis for line-fitting. American Journal of Physical Anthropology: The Official Publication of the American Association of Physical Anthropologists. 140(3):476-486.

Smith BN, Epstein S. 1971. Two categories of 13C/12C ratios for higher plants. Plant physiology. 47(3):380-384.

Solounias N, Teaford M, Walker A. 1988. Interpreting the diet of extinct ruminants: the case of a non-browsing giraffid. Paleobiology. 14(3):287-300.

Solounias N, Semprebon G. 2002. Advances in the eeconstruction of ungulate ecomorphology with application to early fossil equids. Am. Mus. Novit. 225:1-49. 
Sümegi P. 2005. Loess and Upper Paleolithic Environment in Hungary: an Introduction to the Environmental History of Hungary. Aurea Kiado, Nagykovácsi, Hungary.

Sümegi P, Krolopp E. 2002. Quatermalacological analyses for modeling of the Upper Weichselian palaeoenvironmental changes in the Carpathian Basin. Quaternary International. 91(1):53-63.

Sümegi P, Gulyás S, Jakab G. 2008. Holocene paleoclimatic and paleohydrological changes in Lake Balaton as inferred from a complex quantitative environmental historical study of a lacustrine sequence of the Szigliget embayment. Documenta Praehistorica. 35:33-43.

Sümegi P, Molnár M, Jakab G, Persaits G, Majkut P, Páll DG, Gulyás S, Jull AJT, Törcsik T. 2011. Radiocarbon-dated paleoenvironmental changes on a lake and peat sediment sequence from the central Great Hungarian Plain (Central Europe) during the last 25,000 years. Radiocarbon. 53(1):85-97.

Sümegi P, Gulyás S, Csökmei B, Molnár D, Hambach U, Stevens T, Markovic SB, Almond PC. 2012. Climatic fluctuations inferred for the Middle and Late Pleniglacial (MIS 2) based on high-resolution ( ca. 20 y) preliminary environmental magnetic investigation of the loess section of the Madaras brickyard (Hungary). Central European Geology. 55(3):329-345.

Szabó B, Virág A. Forthcoming 2021. Wearing down the constraints of low magnification tooth microwear analysis: Reproducibility and variability of results based on extant ungulates. Paläontologische Zeitschrift.

Szabó P, Kocsis L, Vennemann T, Pandolfi L, Kovács J, Martinetto E, Demény A. 2017. Pliocene-Early Pleistocene climatic trends in the Italian Peninsula based on stable oxygen and carbon isotope compositions of rhinoceros and gomphothere tooth enamel. Quaternary Science Reviews. 157:52-65.

Taylor KL, Beck JL, Huzurbazar SV. 2016. Factors influencing winter mortality risk for pronghorn exposed to wind energy development. Rangeland Ecology \& Management. 69(2):108-116. 
Tixier H, Duncan P. 1996. Are European roe deer browsers? A review of variations in the composition of their diets. Revue D'écologie. 51(1):3-19

Tütken T, Vennemann TW, Janz H, Heizmann EPJ. 2006. Palaeoenvironment and palaeoclimate of the Middle Miocene lake in the Steinheim basin, SW Germany: a reconstruction from $\mathrm{C}, \mathrm{O}$, and $\mathrm{Sr}$ isotopes of fossil remains. Palaeogeography, Palaeoclimatology, Palaeoecology. 241(3-4):457-491.

Tütken T, Kaiser TM, Vennemann TW, Merceron G. 2013. Opportunistic feeding strategy for the earliest Old World hypsodont equids: evidence from stable isotope and dental wear proxies. PLoS One. 8(9):e74463.

Van der Made J. 2010. The rhinos from the Middle Pleistocene of Neumark-Nord (Saxony-Anhalt). Veröffentlichungen des Landesamtes für Denkmalpflege und Archäologie. 62:433-500.

Van der Made J. 2012. The rhinoceros Stephanorhinus aff." etruscus" from the latest Early Pleistocene of Cueva Victoria (Murcia, Spain). Mastia: Revista del Museo Arqueológico Municipal de Cartagena. (11):359-383.

Van Geel B, Sevink J, Mol D, Langeveld BW, Van Der Ham RWJM, Van Der Kraan CJM, Van Der Plicht J, Haile JS, Rey-Iglesia A, Lorenzen ED. 2018. Giant deer (Megaloceros giganteus) diet from Mid-Weichselian deposits under the present North Sea inferred from molar-embedded botanical remains. Journal of Quaternary Science. 33(8):924-933.

Vennemann TW, Fricke HC, Blake RE, O'Neil JR, Colman A. 2002. Oxygen isotope analysis of phosphates: a comparison of techniques for analysis of Ag3PO4. Chemical Geology. 185(3-4):321-336.

Vértes L. 1965. Az Őskőkor és az átmeneti kőkor emlékei Magyarországon... Akadémiai kiadó.

Virág A. 2013. Magyarországi pliocén-pleisztocén Elephantidae maradványok morfometriai és paleokölológiai vizsgálata. (Doctoral dissertation) 
Virág A, Kocsis L, Gasparik M, Vasile Ş. 2014. Palaeodietary reconstruction of fossil proboscideans from Hungary and Romania. Sci. Ann. School Geol. 102:215-216.

Virág A, Pazonyi P. 2014. Cause and timing of late Early-early Middle Pleistocene European mammoth turnover with special emphasis on Hungary. Sci. Ann. School Geol. 102:211-212.

Vogel JC, Waterbolk HT. 1964. Groningen radiocarbon dates V. Radiocarbon. 6:349369.

Wachecka-Kotkowska L, Krzyszkowski D, Malkiewicz M, Mirosław-Grabowska J, Niska M, Krzymińska J, Myśkow E, Raczy J, Wieczorekh D, Stoiński A, et al. 2018. An attempt to reconstruct the late Saalian to Plenivistulian (MIS6-MIS3) natural lake environment from the "Parchliny 2014" section, central Poland. Quaternary international. 467:5-25.

Willis KJ, Braun M, Sümegi P, Tóth A. 1997. Does soil change cause vegetation change or vice versa? A temporal perspective from Hungary. Ecology. 78(3):740-750.

Xafis A, Nagel D, Bastl K. 2017. Which tooth to sample? A methodological study of the utility of premolar/non-carnassial teeth in the microwear analysis of mammals. Palaeogeogr. Palaeoclimatol. Palaeoecol. 487:229-240.

Yamada E, Hasumi E, Miyazato N, Akahoshi M, Watabe M, Nakaya H. 2016. Mesowear analyses of sympatric ungulates from the late Miocene Maragheh, Iran. Palaeobiodiversity and Palaeoenvironments. 96:445-452.

Young TP. 1994. Natural die-offs of large mammals: implications for conservation. Conservation Biology. 8(2):410-418.

Zanazzi A, Judd E, Fletcher A, Bryant H, Kohn MJ. 2015. Eocene--Oligocene latitudinal climate gradients in North America inferred from stable isotope ratios in perissodactyl tooth enamel. Palaeogeography, Palaeoclimatology, Palaeoecology. 417:561-568. 
Zazula GD, Froese DG, Schweger CE, Mathewes RW, Beaudoin AB, Telka AM, Harington CR, Westgate JA. 2003. Ice-age steppe vegetation in east Beringia. Nature. 423(6940):603-603. 
Table 1. GPS coordinates and temporal ranges of the examined Pleistocene and Holocene localities, with the relevant literature cited.

Table 2 . The results of the mesowear analyses of every locality, divided by the cervid species. Mesowear scores of the same species/genera were averaged.

Table 3. Results of the microwear analysis of the examined specimens, grouped by localities. If it was possible, five sampling areas were quantified, and the minimum, maximum, average and standard deviation values were given based on these iterations.

Table 4. Results of the ${ }^{13} \mathrm{C}$ and ${ }^{18} \mathrm{O}$ stable isotope analyses conducted on the enamel of selected cervid specimens. The calculated environmental water $\delta^{18} \mathrm{O}$ value and the calculated mean annual temperature is indicated as well.

Figure 1. Location of paleontological sites (1. Osztramos 8; 2. Gombasek; 3. Üröm Hill; 4. Vértesszőlős II; 5. Tarkő Rock-shelter; 6. Vár Cave; 7. Szuhogy-Csorbakő; 8. Hórvölgy Rock-shelter; 9. Uppony I; 10. Lambrecht Cave; 11. Kiskevély Cave; 12. Tapolca Cave; 13. Tokod-Nagyberek I; 14. Szeleta Cave; 15. Istállóskő Cave; 16. Szelim Cave; 17. Zebegény; 18. Zalaegerszeg; 19. Ságvár; 20. Mogyorósbánya; 21. Pilismarót; 22. Jankovich Cave; 23. Peskő Cave; 24. Berva-völgy Cave; 25. Remete Cave; 26. Petényi Cave; 27. Baradla Cave; 28. Kiskőhát Cave).

Figure 2. Temporal ranges of the Pleistocene and Holocene localities.

Figure 3. Major axis regression showing the relation between measured air temperature $\left({ }^{\circ} \mathrm{C}\right)$ and measured $\delta 180$ of precipitation. The equation shows how to calculate air temperature from known precipitation $\delta 180$ values.

Figure 4. Major axis regression showing the relation between $\delta^{18} \mathrm{O}$ of enamel $\mathrm{PO}_{4}$ of extant cervids, suids and bovids and $\delta^{18} \mathrm{O}$ of ingested meteoric water. The grey background distribution and the dashed line shows the relation between measured air temperature $\left({ }^{\circ} \mathrm{C}\right)$ and measured $\delta^{18} \mathrm{O}$ of precipitation. The equations show how to calculate a hypothetical water $\delta^{18} \mathrm{O}$ value based on measured enamel $\mathrm{PO}_{4} \delta^{18} \mathrm{O}$ value, and how to calculate air temperature from the previously calculated precipitation $\delta^{18} \mathrm{O}$ values. 
Figure 5. The results of the stable isotope analyses and the dental wear analyses: A) The change of calculated mean annual temperatures based on the $\delta^{18} \mathrm{O}$ values of cervid enamel samples in relation to the age. Horizontal and vertical lines next to each data point indicate the uncertainty of age and the standard deviation of the temperature measurements. The $\delta^{18} \mathrm{O}$ curve for comparison in the background is based on the work of Lisiecki and Raymo (2005). B) The change of the carbon isotopic composition of foraged plants based on the $\delta^{13} \mathrm{C}$ values of cervid enamel samples in relation to the age. Horizontal and vertical lines next to each data point indicate the uncertainty of age and the standard deviation of the temperature measurements. The $\delta^{18} \mathrm{O}$ curve for comparison in the background is based on the work of Lisiecki and Raymo (2005). C) The change of average mesowear score for the examined cervid genera in relation to age. Horizontal lines show the standard deviation of the average scores. The dashed lines in the background are to help indicate the sequence of localities, they do not hold any other meaning. D) The changes of microwear pattern of the examined cervid genera in relation to age. Cervids were appointed into one of three main dietary categories based on their signature microwear, following the propsitions of Solounias and Semprebon (2002) and Semprebon et al. (2004). The $\delta^{18} \mathrm{O}$ curve for comparison in the background is based on the work of Lisiecki and Raymo (2005). Indices on the right follow the numbers explained in the legend of Figure 1.

Figure 6. Microwear pattern of the examined cervid groups plotted against the dietary morphospaces proposed by Solounias and Semprebon (2002) and Semprebon et al. (2004). The morphospace on the left represents the microwear of present day browsing herbivores, whereas the morphospace on the right represents present day grazers. Areas in between indicate an intermediate feeder diet.

Figure 7. Measured oxygen isotopic compositions of enamel carbonate and phosphate. The isotopic equilibrium line between carbonate and phosphate $\delta^{18} \mathrm{O}$ values is plotted for reference along with the $95 \%$ confidence interval calculated by Pellegrini et al. (2011) on modern cervids. 


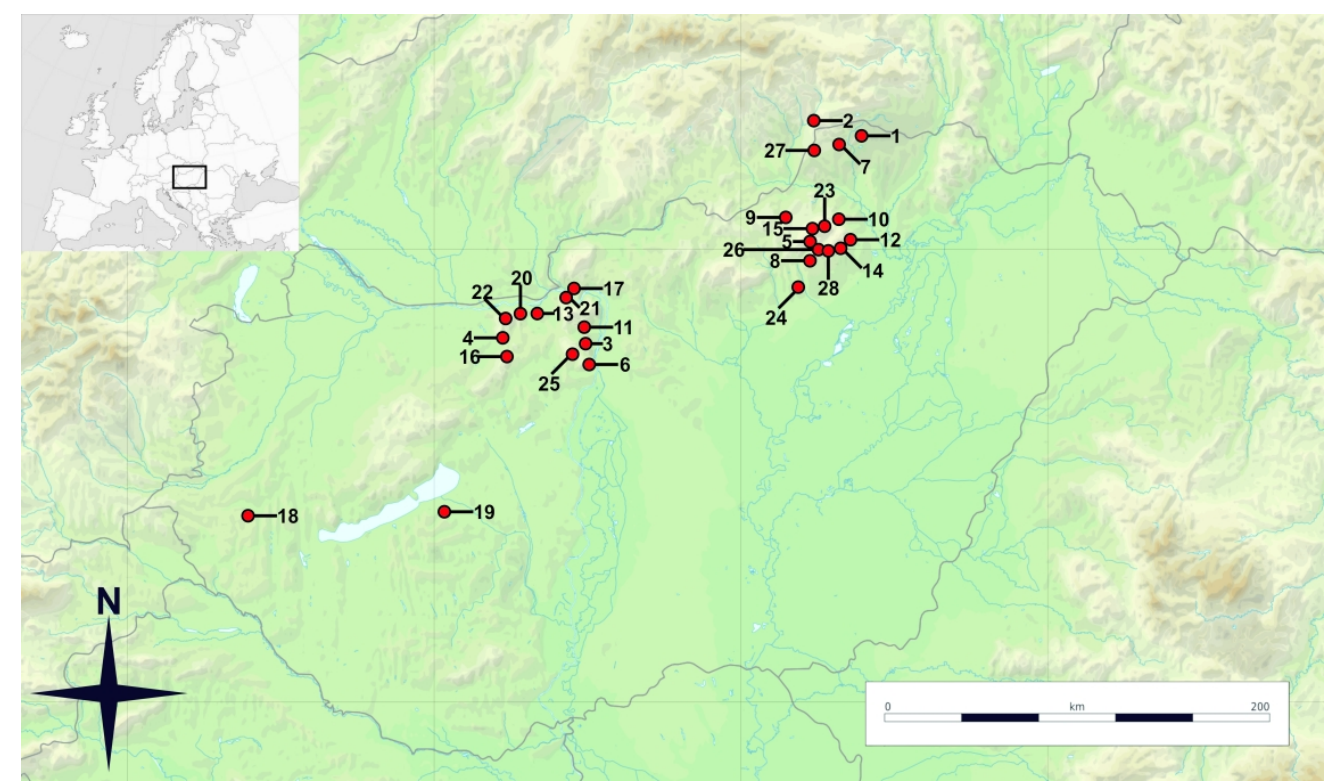

Figure 1. Location of paleontological sites (1. Osztramos 8; 2. Gombasek; 3. Üröm Hill; 4. Vértesszőlős II; 5. Tarkő Rock-shelter; 6. Vár Cave; 7. Szuhogy-Csorbakő; 8. Hórvölgy Rock-shelter; 9. Uppony I; 10. Lambrecht Cave; 11. Kiskevély Cave; 12. Tapolca Cave; 13. Tokod-Nagyberek I; 14. Szeleta Cave; 15. Istállóskő Cave; 16. Szelim Cave; 17. Zebegény; 18. Zalaegerszeg; 19. Ságvár; 20. Mogyorósbánya; 21. Pilismarót; 22. Jankovich Cave; 23. Peskö Cave; 24. Berva-völgy Cave; 25. Remete Cave; 26. Petényi Cave; 27. Baradla Cave; 28. Kiskőhát Cave).

$$
296 \times 175 \mathrm{~mm}(500 \times 500 \text { DPI) }
$$



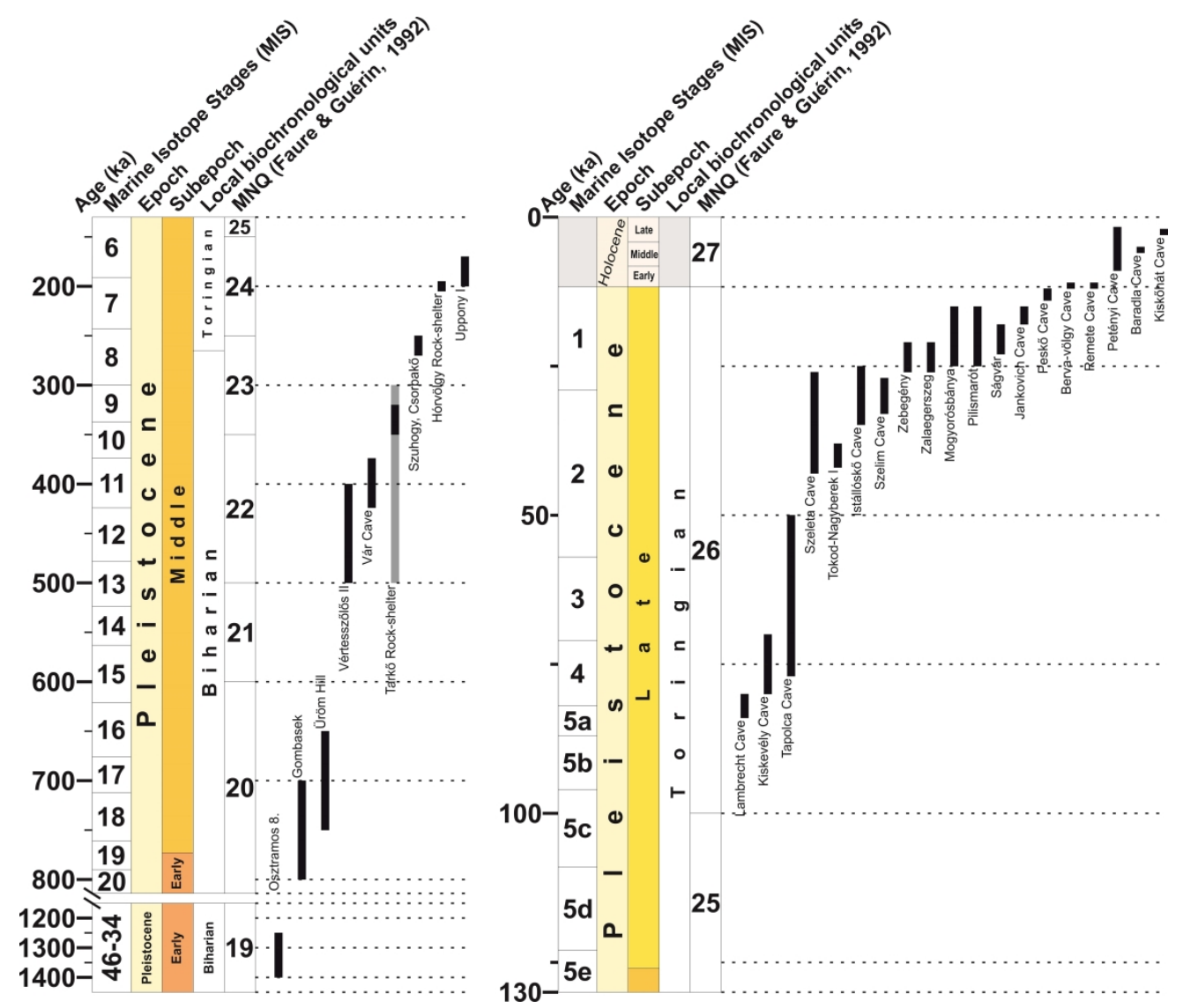

Figure 2. Temporal ranges of the Pleistocene and Holocene localities.

$1756 \times 1509 m m(96 \times 96$ DPI) 


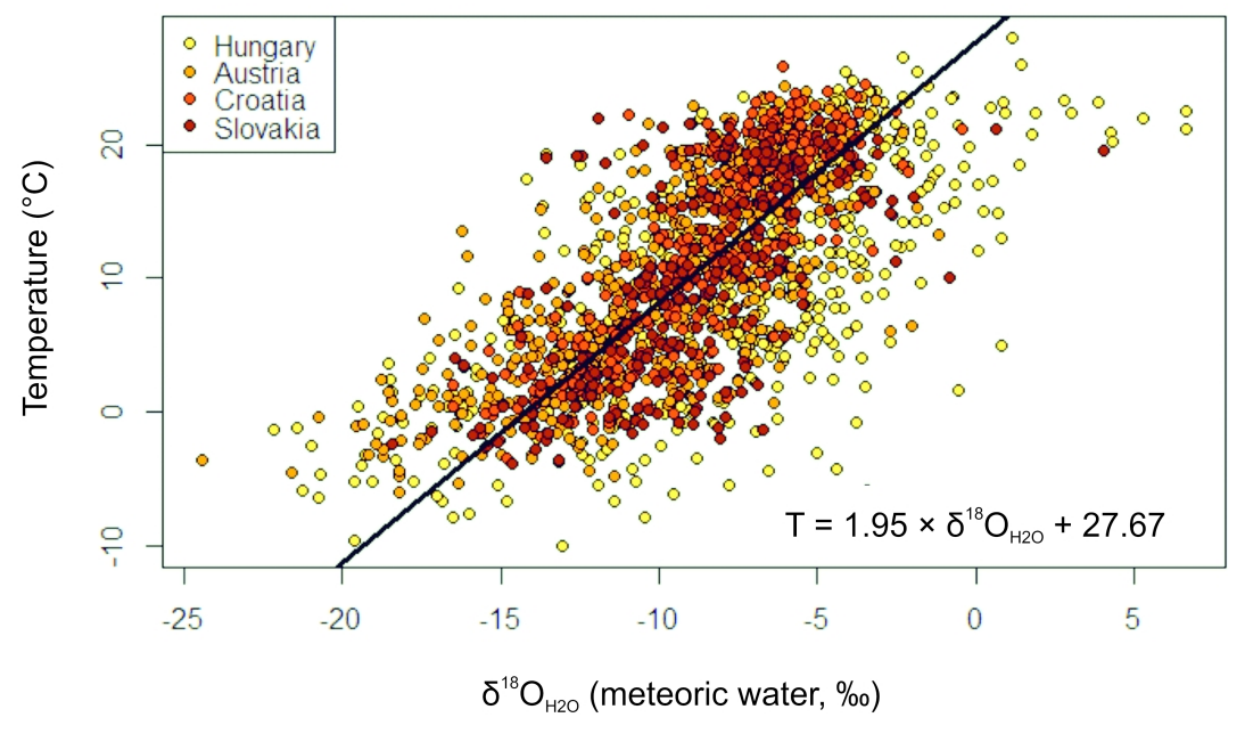

Figure 3. Major axis regression showing the relation between measured air temperature $\left({ }^{\circ} \mathrm{C}\right)$ and measured $\delta^{18} \mathrm{O}$ of precipitation. The equation shows how to calculate air temperature from known precipitation $\delta^{18} \mathrm{O}$ values.

$192 \times 128 \mathrm{~mm}(500 \times 500 \mathrm{DPI})$ 


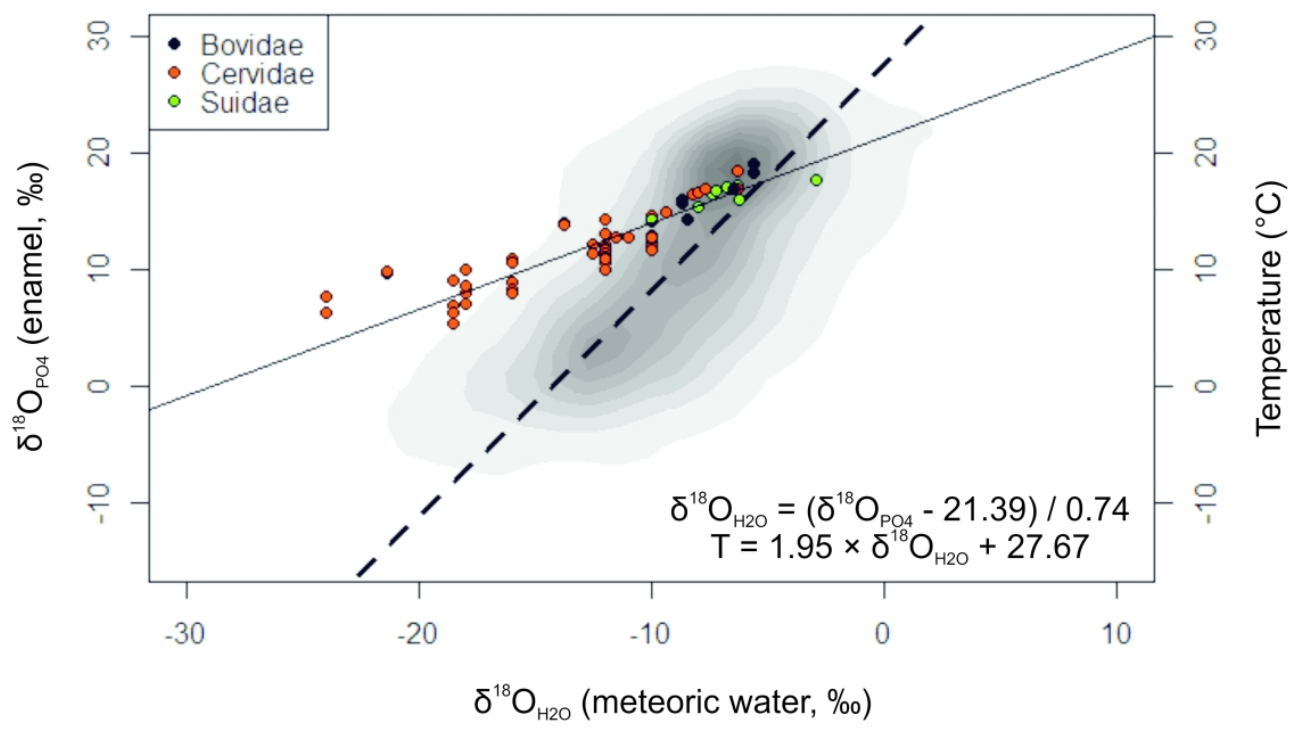

Figure 4. Major axis regression showing the relation between $\delta^{18} \mathrm{O}$ of enamel $\mathrm{PO}_{4}$ of extant cervids, suids and bovids and $\delta^{18} \mathrm{O}$ of ingested meteoric water. The grey background distribution and the dashed line shows the relation between measured air temperature $\left({ }^{\circ} \mathrm{C}\right)$ and measured $\delta^{18} \mathrm{O}$ of precipitation. The equations show how to calculate a hypothetical water $\delta^{18} \mathrm{O}$ value based on measured enamel $\mathrm{PO}_{4} \delta^{18} \mathrm{O}$ value, and how to calculate air temperature from the previously calculated precipitation $\delta^{18} \mathrm{O}$ values.

$192 \times 132 \mathrm{~mm}(500 \times 500 \mathrm{DPI})$ 


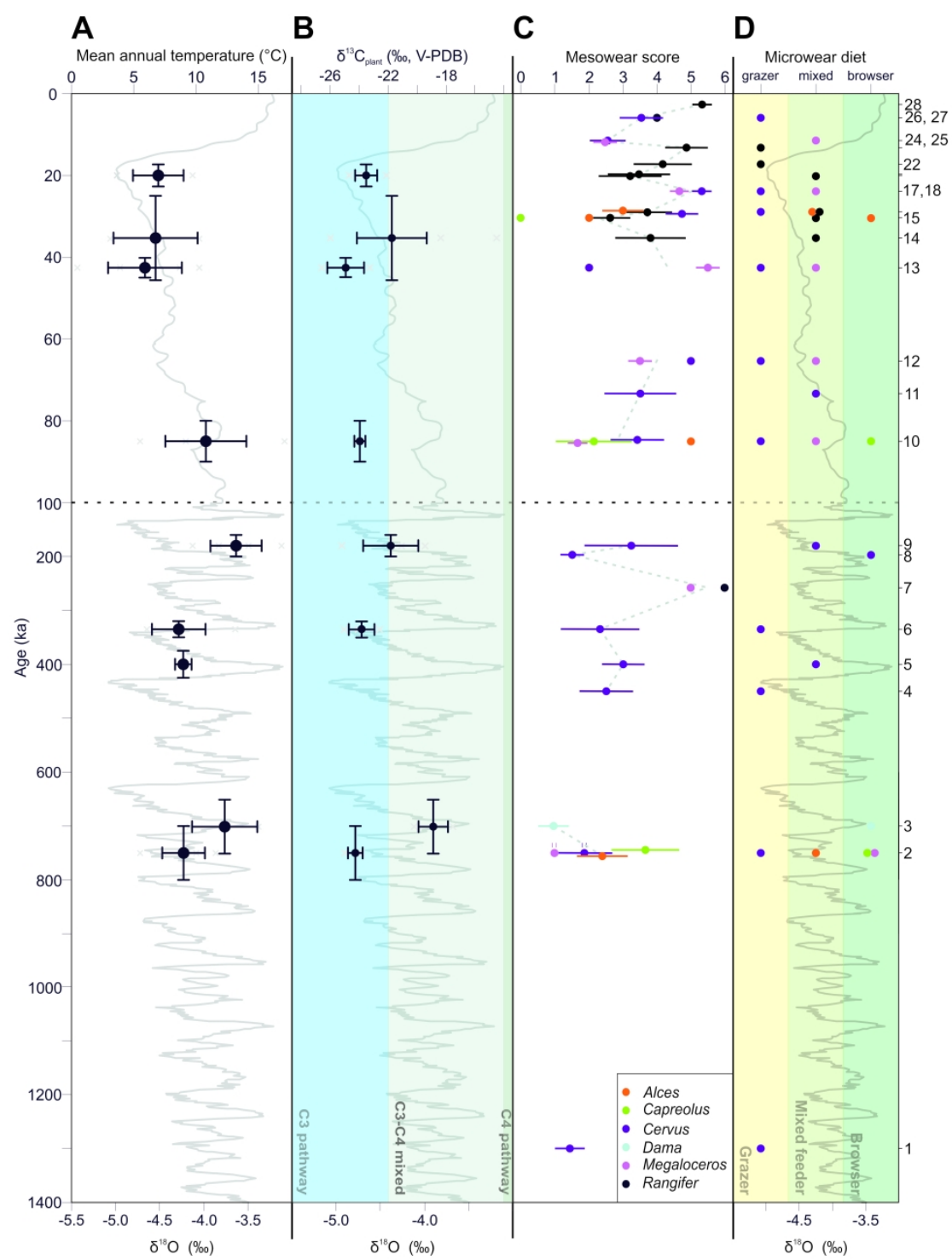

Figure 5. The results of the stable isotope analyses and the dental wear analyses: A) The change of calculated mean annual temperatures based on the $\delta^{18} \mathrm{O}$ values of cervid enamel samples in relation to the age. Horizontal and vertical lines next to each data point indicate the uncertainty of age and the standard deviation of the temperature measurements. The $\delta^{18} \mathrm{O}$ curve for comparison in the background is based on the work of Lisiecki and Raymo (2005). B) The change of the carbon isotopic composition of foraged plants based on the $\delta^{13} \mathrm{C}$ values of cervid enamel samples in relation to the age. Horizontal and vertical lines next

to each data point indicate the uncertainty of age and the standard deviation of the temperature measurements. The $\delta^{18} \mathrm{O}$ curve for comparison in the background is based on the work of Lisiecki and Raymo (2005). C) The change of average mesowear score for the examined cervid genera in relation to age. Horizontal lines show the standard deviation of the average scores. The dashed lines in the background are

to help indicate the sequence of localities, they do not hold any other meaning. D) The changes of microwear pattern of the examined cervid genera in relation to age. Cervids were appointed into one of three dietary categories based on their signature microwear following the propsitions of Solounias and 
Semprebon (2002) and Semprebon et al. (2004). The $\delta^{18} \mathrm{O}$ curve for comparison in the background is based on the work of Lisiecki and Raymo (2005). Indices on the right follow the numbers explained in the legend of Figure 1.

$274 \times 362 \mathrm{~mm}(500 \times 500 \mathrm{DPI})$ 


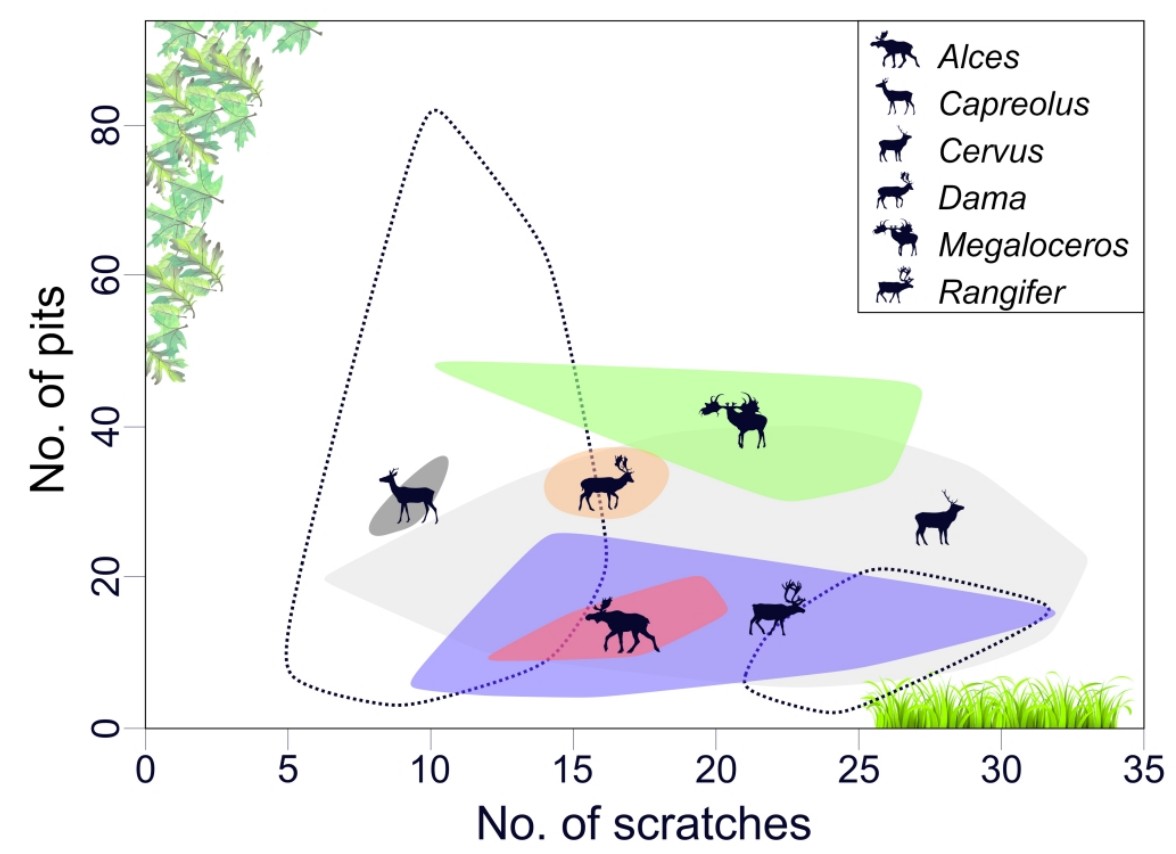

Figure 6. Microwear pattern of the examined cervid groups plotted against the dietary morphospaces proposed by Solounias and Semprebon (2002) and Semprebon et al. (2004). The morphospace on the left represents the microwear of present day browsing herbivores, whereas the morphospace on the right represents present day grazers. Areas in between indicate an intermediate feeder diet.

$199 \times 146 \mathrm{~mm}(500 \times 500 \mathrm{DPI})$ 


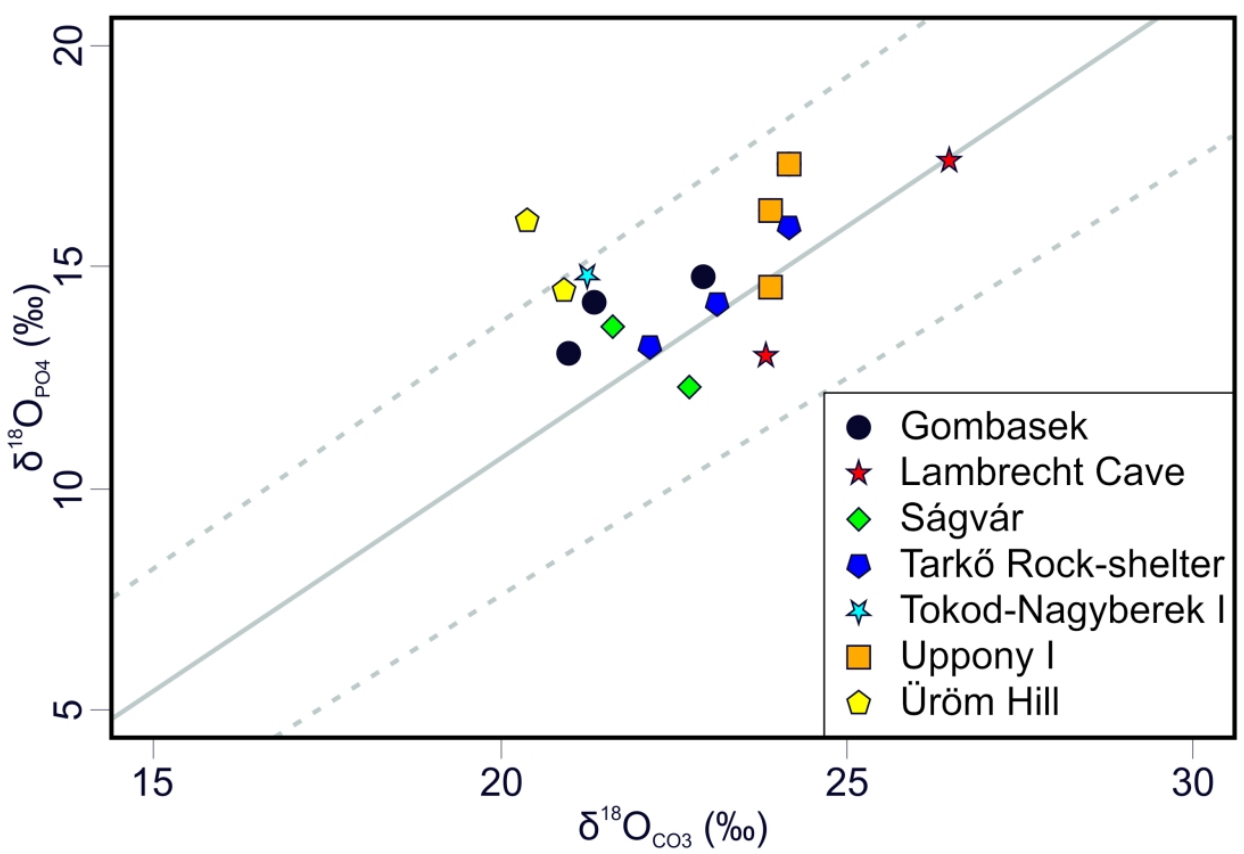

Figure 7. Measured oxygen isotopic compositions of enamel carbonate and phosphate. The isotopic equilibrium line between carbonate and phosphate $\delta^{18} \mathrm{O}$ values is plotted for reference along with the $95 \%$ confidence interval calculated by Pellegrini et al. (2011) on modern cervids.

$141 \times 99 \mathrm{~mm}(500 \times 500 \mathrm{DPI})$ 


\begin{tabular}{llll} 
Locality & Latitude (DD) & Longitude (DD) & Age (ka) \\
\hline Osztramos 8 & 48.5183 & 20.7509 & $1300 \pm 500$ \\
Gombasek & 48.5628 & 20.4665 & $750 \pm 50$ \\
Üröm Hill & 47.5958 & 19.0213 & $700 \pm 50$ \\
Vértesszőlős II & 47.6262 & 18.3844 & $450 \pm 50$ \\
Vár Cave (Fortuna street) & 47.5042 & 19.0311 & $400 \pm 25$ \\
Tarkö Rock-shelter (layers 5-7) & 48.0571 & 20.4644 & $330 \pm 20$ \\
Szuhogy-Csorbakö & 48.3972 & 20.6539 & $260 \pm 10$ \\
Hórvölgy Rock-shelter & 47.9611 & 20.5305 & $200 \pm 5$ \\
Uppony I & 48.2123 & 20.4447 & $185 \pm 15$ \\
Lambrecht Cave & 48.1347 & 20.6106 & $83 \pm 3$ \\
Kiskevély Cave & 47.6328 & 18.9695 & $75 \pm 5$ \\
Tapolca Cave & 48.0968 & 20.6885 & $64 \pm 14$ \\
Tokod-Nagyberek I & 47.7142 & 18.6477 & $40 \pm 2$ \\
Szeleta Cave & 48.1081 & 20.6312 & $35 \pm 9$ \\
Istállóskő Cave & 48.0716 & 20.4173 & $30 \pm 4$ \\
Zebegény & 47.7994 & 18.9133 & $23 \pm 3$ \\
Zalaegerszeg & 48.864 & 16.864 & $23 \pm 3$ \\
Szelim Cave & 47.5905 & 18.4071 & $22 \pm 2$ \\
Mogyorósbánya & 47.7313 & 18.5982 & $20 \pm 5$ \\
Pilismarót & 47.7949 & 18.8508 & $20 \pm 5$ \\
Ságvár & 46.8242 & 18.0928 & $20 \pm 3$ \\
Jankovich Cave & 47.7239 & 18.5752 & $16 \pm 2$ \\
Peskő Cave & 48.0481 & 20.4236 & $13 \pm 1$ \\
Berva-völgy Cave & 47.9611 & 20.3715 & $11.5 \pm 1$ \\
Remete Cave & 47.5611 & 18.9276 & $11.5 \pm 1$ \\
Petényi Cave & 48.0476 & 20.4239 & $5 \pm 4$ \\
Baradla Cave & 48.4717 & 20.4953 & $5 \pm 1$ \\
Kiskőhát Cave & 48.0683 & 20.4903 & $2.5 \pm 1$
\end{tabular}




\section{Reference}

Jánossy 1972; 1986

Gasparik and Wagner 2014

Virág and Pazonyi 2014

Ruszkiczay-Rüdiger et al. 2018

Kordos 2004

Jánossy 1986; Luzi et al. 2019

Jánossy and Vörös 1985

Jánossy 1986; Kordos 1994

Jánossy et al. 1968

Kordos 1991; Gasparik 1993; Luzi et al. 2019

Dobosi and Vörös 1994; Markó 2009

Hellebrandt et al. 1976; Kordos 1991; Ringer and Moncel 2002

Jánossy 1986; Luzi et al. 2019

Ringer 2002; Adams 2002; Davies and Hedges 2008

Vértes 1965; Ringer 2002

Kovács 2012

Kovács 2012

Bradák and Markó 2006; Mészáros 2004

Dobosi 2016

Dobosi 2016

Sümegi and Krolopp 2002; Bösken et al. 2018; Vogel and Waterbolk 1964

Markó 2013; Pazonyi 2004

Vértes 1965

Gábori 1976

Gábori 1976

Vértes 1965

Fükőh 1995; Kordos 1981

Kordos 1981; Pazonyi 2004 


\begin{tabular}{|c|c|c|c|c|c|c|c|}
\hline \multirow{2}{*}{ Locality } & \multirow{2}{*}{ Taxa } & \multirow{2}{*}{$\mathbf{N}$} & \multicolumn{5}{|c|}{ Mesowear score } \\
\hline & & & 0 & 1 & 2 & 3 & 4 \\
\hline \multirow[t]{2}{*}{ Osztramos 8} & Cervus sp. & 9 & 2 & 1 & 6 & - & - \\
\hline & Alces sp. & 10 & - & 3 & 4 & 1 & - \\
\hline \multirow{3}{*}{ Gombasek } & Capreolus sp. & 9 & - & 3 & - & - & - \\
\hline & Cervus sp. & 41 & 9 & 9 & 14 & 2 & 3 \\
\hline & Megaloceros sp. & 1 & - & 1 & - & - & - \\
\hline Üröm Hill & Dama sp. & 6 & 2 & 2 & 2 & - & - \\
\hline Vértesszőllős II & Cervus sp. & 7 & - & 2 & 2 & 1 & 1 \\
\hline Tarkő Rock-shelter & Cervus acoronatus & 3 & - & 2 & - & - & - \\
\hline Vár Cave & Cervus cf. elaphus & 3 & - & 1 & - & 1 & - \\
\hline \multirow{2}{*}{ Szuhogy - Csorbakő } & Megaloceros sp. & 1 & - & - & - & - & - \\
\hline & Rangifer tarandus & 1 & - & - & - & - & - \\
\hline Hórvölgy Rock-shelter & Cervus sp. & 2 & - & 1 & 1 & - & - \\
\hline \multirow[t]{2}{*}{ Uppony I. } & Cervus sp. & 8 & 2 & 1 & 1 & - & - \\
\hline & Alces alces & 1 & - & - & - & - & - \\
\hline \multirow{3}{*}{ Lambrecht Cave } & Capreolus capreolus & 13 & 5 & 1 & 2 & 1 & 1 \\
\hline & Cervus elaphus & 16 & - & 3 & 1 & 4 & 3 \\
\hline & Megaloceros giganteus & 3 & - & 1 & 2 & - & - \\
\hline \multirow{2}{*}{ Kiskevély Cave } & Alces alces & 2 & - & - & 1 & - & - \\
\hline & Cervus elaphus & 2 & - & - & 1 & - & - \\
\hline \multirow{2}{*}{ Tapolca Cave } & Cervus elaphus & 1 & - & - & - & - & - \\
\hline & Megaloceros giganteus & 2 & - & - & - & 1 & 1 \\
\hline \multirow{2}{*}{ Tokod - Nagyberek I } & Cervus elaphus & 1 & - & - & 1 & - & - \\
\hline & Megaloceros giganteus & 2 & - & - & - & - & - \\
\hline \multirow[t]{2}{*}{ Szeleta Cave } & Rangifer tarandus & 15 & 1 & 1 & 3 & 2 & 1 \\
\hline & Alces alces & 2 & - & - & 2 & - & - \\
\hline \multirow[t]{3}{*}{ Istállóskő Cave } & Capreolus capreolus & 1 & 1 & - & - & - & - \\
\hline & Rangifer tarandus & 8 & - & 1 & 3 & 3 & - \\
\hline & Alces alces & 5 & - & - & 2 & 2 & - \\
\hline \multirow[t]{2}{*}{ Szelim Cave } & Cervus elaphus & 4 & - & - & - & - & 2 \\
\hline & Rangifer tarandus & 19 & - & 2 & 5 & 2 & 2 \\
\hline Zebegény & Cervus elaphus & 3 & - & - & - & - & - \\
\hline Zalaegerszeg & Megaloceros giganteus & 3 & - & - & - & - & 1 \\
\hline Ságvár & Rangifer tarandus & 385 & 9 & 54 & 52 & 54 & 35 \\
\hline Mogyorósbánya & Rangifer tarandus & 7 & - & 1 & 2 & 1 & 1 \\
\hline Pilismarót & Rangifer tarandus & 92 & 8 & 10 & 21 & 9 & 18 \\
\hline Jankovich Cave & Rangifer tarandus & 6 & - & - & 1 & 2 & - \\
\hline Peskő Cave & Rangifer tarandus & 8 & - & - & 2 & - & - \\
\hline \multirow{2}{*}{ Berva-völgy Cave } & Cervus elaphus & 3 & - & 1 & - & 1 & 1 \\
\hline & Megaloceros giganteus & 2 & - & - & 1 & 1 & - \\
\hline Remete Cave & Cervus elaphus & 3 & - & - & 2 & 1 & - \\
\hline \multirow{2}{*}{ Petényi Cave } & Cervus elaphus & 6 & - & - & 1 & 2 & 1 \\
\hline & Rangifer tarandus & 2 & - & - & - & - & 2 \\
\hline Baradla Cave & Cervus elaphus & 5 & - & 1 & - & 1 & 1 \\
\hline Kiskőháti Cave & Rangifer tarandus & 3 & - & - & - & - & - \\
\hline
\end{tabular}


2

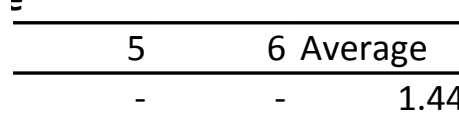

$2 \quad-\quad 2.4$

$6 \quad-\quad 3.67$

$\begin{array}{lll}2 & 2 & 1.87\end{array}$

$\begin{array}{lll}2 & -\end{array}$

$\begin{array}{lll}- & - & 1\end{array}$

$1 \quad-\quad 2.57$

$1 \quad-\quad 2.33$

$1 \quad-\quad 3$

$1 \quad 5$

$\begin{array}{lll}- & 1\end{array}$

$\begin{array}{lll}- & - & 1.5\end{array}$

13.25

$1 \quad 5$

$2 \quad 1 \quad 2.15$

$\begin{array}{lll}4 & 1 & 3.44\end{array}$

- $\quad$ - 1.67

$1 \quad-\quad 3.5$

$1 \quad-\quad 3.5$

$1 \quad 5$

$\begin{array}{lll}1 & - & \\ - & \end{array}$

- $\quad 2$

$\begin{array}{lll}1 & 1 & 5.5\end{array}$

$\begin{array}{lll}2 & 5 & 3.8\end{array}$

$\begin{array}{lll}2 & -\end{array}$

- $\quad-\quad 0$

$1 \quad-\quad 2.63$

$1 \quad-\quad 3$

114.75

$\begin{array}{lll}3 & 5 & 3.74\end{array}$

$2 \quad 1 \quad 5.33$

$2 \quad-\quad 4.67$

$\begin{array}{lll}70 & 56 \quad 3.47\end{array}$

\begin{tabular}{l}
-6.43 \\
\hline
\end{tabular}

$14 \quad 12 \quad 3.19$

$\begin{array}{lll}1 & 2 & 4.17\end{array}$

$3 \quad 35$

$\begin{array}{lll}-\quad & - \\ \end{array}$

$\begin{array}{lll}-\quad & - \\ \end{array}$

- $\quad$ - 2.33

$2 \quad-\quad 3.67$

- $\quad$ - 4

$2 \quad-\quad 3.4$

$2 \quad 1 \quad 5.33$

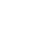

ra

4

5

5

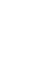




\begin{tabular}{|c|c|c|c|c|c|}
\hline \multirow{2}{*}{ Locality } & \multirow{2}{*}{ Taxon } & \multirow{2}{*}{ ID } & \multicolumn{3}{|c|}{ Scratches } \\
\hline & & & Minimum & Average & Maximum \\
\hline \multirow{2}{*}{ Baradla Cave } & Cervus elaphus & V. 27070. & 12 & 16.7 & 21 \\
\hline & Cervus elaphus & V. 27070 & 20 & 25.3 & 31 \\
\hline \multirow[t]{2}{*}{ Berva-völgy Cave } & Megaloceros giganteus & V. 63.1514. & 21 & 24.2 & 26 \\
\hline & Cervus elaphus & V. 63.1496. & 38 & 45.7 & 49 \\
\hline \multirow{6}{*}{ Tapolca Cave } & Megaloceros giganteus & V. 63.1442. & 20 & 27.3 & 31 \\
\hline & Megaloceros giganteus & V. 63. 1445. & 21 & 25 & 28 \\
\hline & Megaloceros giganteus & V. 63.1482. & 24 & 28.6 & 32 \\
\hline & Alces sp. & V. 59. 957. & - & 16 & - \\
\hline & Alces sp. & V. 59. 988. & - & 17 & - \\
\hline & Capreolus sp. & v. 60.1770. & 8 & 9.4 & 11 \\
\hline \multirow[t]{4}{*}{ Gombasek } & Cervus sp. & V. 59.944. & 25 & 27.3 & 31 \\
\hline & Cervus sp. & V. 59. 944. & - & 26 & - \\
\hline & Cervus sp. & V. 59. 970. & - & 26 & - \\
\hline & Megaloceros sp. & V. 59. 927. & - & 9 & - \\
\hline \multirow{3}{*}{ Hórvölgy Rock-shelter } & Cervus sp. & M. S. 01. & 6 & 8.8 & 12 \\
\hline & Cervus sp. & M. S. 02. & 11 & 16 & 19 \\
\hline & Alces alces & V. 59. 379. & 12 & 14 & 17 \\
\hline \multirow[t]{2}{*}{ Istállóskő Cave } & Rangifer tarandus & V. 59. 389. & 12 & 17.6 & 21 \\
\hline & Rangifer tarandus & V. 59. 424. & - & 14 & - \\
\hline Jankovich Cave & Rangifer tarandus & V. 14659. & 26 & 29.2 & 34 \\
\hline \multirow[t]{3}{*}{ Kiskevély Cave } & Cervus elaphus & V. 60. 955. & 21 & 23.6 & 26 \\
\hline & Capreolus capreolus & V. 58. 1619. & - & 9 & - \\
\hline & Cervus elaphus & V. 58. 1078. & 20 & 24 & 31 \\
\hline \multirow[t]{3}{*}{ Lambrecht Kálmán Cave } & Cervus elaphus & V. 58. 1078. & 23 & 25.4 & 27 \\
\hline & Cervus elaphus & V. 58. 1548. & 22 & 23.8 & 27 \\
\hline & Megaloceros giganteus & V. 58. 1063. & 18 & 19.6 & 21 \\
\hline Osztramos 8. & Cervus sp. & V. 73.70. & 18 & 23.6 & 27 \\
\hline \multirow{3}{*}{ Peskő Cave } & Rangifer tarandus & V. 14274. & 21 & 27.2 & 30 \\
\hline & Rangifer tarandus & V. 14277. & 19 & 23.8 & 26 \\
\hline & Cervus elaphus & V. 61. 2021. & 14 & 19 & 22 \\
\hline \multirow[t]{6}{*}{ Petényi Cave } & Cervus elaphus & V. 61. 1292. & 22 & 27.2 & 31 \\
\hline & Cervus elaphus & V. 61. 1292. & 25 & 26.8 & 31 \\
\hline & Rangifer tarandus & V.60. 1503. & 12 & 15.2 & 20 \\
\hline & Rangifer tarandus & V. 60. 1532. & & 18 & - \\
\hline & Rangifer tarandus & V.60. 1559. & & 17 & - \\
\hline & Rangifer tarandus & V. 60. 1559. & - & 15 & - \\
\hline \multirow{7}{*}{ Ságvár } & Rangifer tarandus & V. 60. 1561. & 12 & 13.2 & 16 \\
\hline & Rangifer tarandus & V. 60. 1561. & 12 & 15 & 20 \\
\hline & Rangifer tarandus & V.60. 1561. & 13 & 16.6 & 19 \\
\hline & Rangifer tarandus & V.60. 1561. & 14 & 16.4 & 19 \\
\hline & Rangifer tarandus & V. 60. 1561. & - & 18 & - \\
\hline & Rangifer tarandus & V.60. 1561. & - & 13 & - \\
\hline & Rangifer tarandus & V. 63. 1661. & 14 & 14.8 & 16 \\
\hline \multirow[t]{5}{*}{ Szeleta Cave } & Rangifer tarandus & V. 63. 1705. & 22 & 23 & 24 \\
\hline & Rangifer tarandus & V. 63. 1705. & - & 25 & - \\
\hline & Alces alces & G. 57. 517. & 14 & 17.2 & 20 \\
\hline & Alces alces & G. 57. 675 . & 18 & 19.4 & 21 \\
\hline & Alces alces & G. 57. 675 . & 17 & 18 & 19 \\
\hline
\end{tabular}




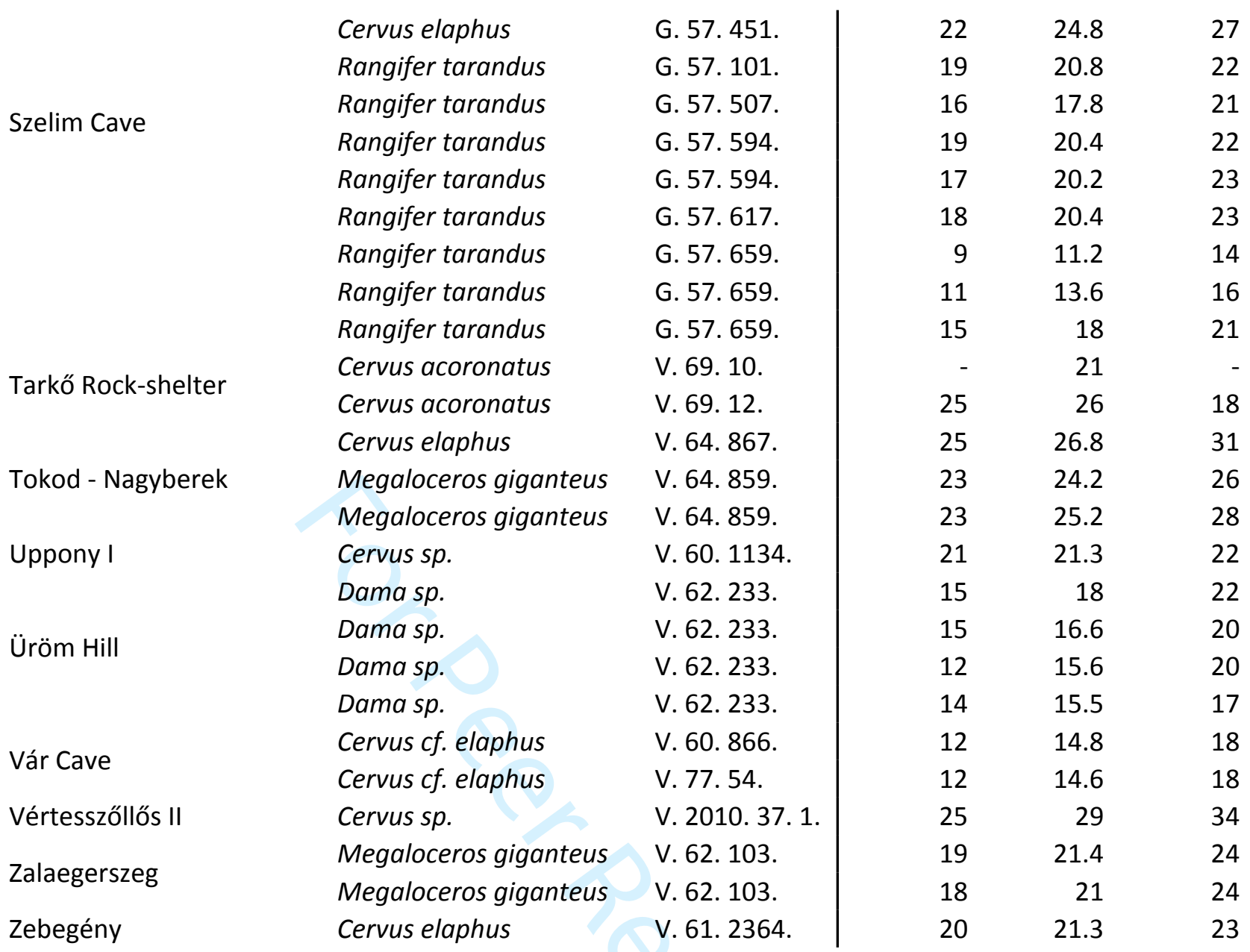


Pits

\begin{tabular}{|c|c|c|c|c|}
\hline SD & Minimum & Average & Maximum & SD \\
\hline 4.5 & 17 & 20.2 & 24 & 3.51 \\
\hline 3.34 & 26 & 29.6 & 33 & 2.18 \\
\hline 1.92 & 29 & 31 & 33 & 1.58 \\
\hline 5.65 & 8 & 12 & 16 & 3.84 \\
\hline 5.6 & 27 & 31.2 & 36 & 4.5 \\
\hline 3.51 & 21 & 26.3 & 29 & 4.07 \\
\hline 4.02 & 14 & 20.1 & 24 & 5.04 \\
\hline & - & 16 & - & - \\
\hline & - & 14 & - & - \\
\hline 1.34 & 24 & 30.6 & 35 & 4,82 \\
\hline 2.63 & 20 & 23.5 & 26 & 2.65 \\
\hline & - & 27 & - & - \\
\hline & - & 39 & - & - \\
\hline & - & 49 & - & - \\
\hline 3 & 18 & 24.2 & 29 & 5.52 \\
\hline 4.04 & 25 & 30.1 & 37 & 6.02 \\
\hline 2.45 & 8 & 12.6 & 18 & 3.85 \\
\hline 3.36 & 6 & 13.6 & 18 & 4.83 \\
\hline & - & 26 & - & - \\
\hline 4.03 & 12 & 14 & 16 & 1.84 \\
\hline 2.07 & 24 & 31 & 38 & 5.57 \\
\hline & - & 27 & - & - \\
\hline 4.36 & 10 & 19.2 & 23 & 5.26 \\
\hline 1.52 & 15 & 17.6 & 22 & 2.88 \\
\hline 1.92 & 7 & 8.2 & 9 & 0.84 \\
\hline 1.34 & 41 & 43.6 & 46 & 2.07 \\
\hline 3.44 & 16 & 19.2 & 26 & 4.15 \\
\hline 4.61 & 8 & 12 & 17 & 4.51 \\
\hline 3.56 & 9 & 12.8 & 15 & 3.04 \\
\hline 4.04 & 25 & 31.4 & 37 & 6.01 \\
\hline 3.7 & 11 & 12.4 & 14 & 1.14 \\
\hline 2.49 & 9 & 14 & 18 & 3.87 \\
\hline 3.27 & 6 & 8.8 & 16 & 4.21 \\
\hline & - & 8 & - & - \\
\hline & - & 7 & - & - \\
\hline & - & 9 & - & - \\
\hline 1.64 & 6 & 7.4 & 9 & 1.14 \\
\hline 3.16 & 4 & 6.6 & 9 & 1.82 \\
\hline 2.88 & 7 & 9.2 & 12 & 1.92 \\
\hline 2.07 & 6 & 8.2 & 9 & 1.3 \\
\hline & - & 8 & - & - \\
\hline & - & 16 & - & - \\
\hline 1.1 & 22 & 23.8 & 26 & 1.64 \\
\hline 1.41 & 9 & 9.5 & 10 & 0.71 \\
\hline & - & 8 & - & \\
\hline 2.28 & 15 & 18 & 22 & 2.65 \\
\hline 1.14 & 13 & 14.2 & 16 & 1.3 \\
\hline 0.71 & 9 & 13.2 & 19 & 3.89 \\
\hline
\end{tabular}




\begin{tabular}{r|rrrr}
1.92 & 10 & 12.4 & 17 & 2.7 \\
1.3 & 8 & 11.4 & 15 & 2.61 \\
1.92 & 6 & 7.4 & 10 & 1.67 \\
1.34 & 8 & 11.2 & 13 & 1.92 \\
2.17 & 9 & 11.2 & 13 & 2.05 \\
2.41 & 11 & 13.2 & 16 & 1.92 \\
2.28 & 5 & 6 & 7 & 0.71 \\
1.82 & 7 & 8 & 9 & 1 \\
2.24 & 3 & 7.4 & 12 & 3.21 \\
- & - & 14 & - & - \\
1.22 & 14 & 15.4 & 17 & 1.14 \\
2.49 & 6 & 7.4 & 9 & 1.14 \\
1.3 & 41 & 43.2 & 47 & 2.49 \\
2.28 & 37 & 42.6 & 46 & 3.65 \\
0.58 & 22 & 24.3 & 26 & 2.08 \\
2.74 & 31 & 34.2 & 38 & 2.86 \\
2.07 & 29 & 33.8 & 40 & 4.76 \\
3.05 & 25 & 31.4 & 36 & 4.04 \\
2.12 & 33 & 33.5 & 34 & 0.71 \\
2.39 & 24 & 27.6 & 31 & 2.7 \\
2.41 & 10 & 13.4 & 20 & 3.85 \\
4.51 & 13 & 18.2 & 21 & 4.06 \\
2.3 & 39 & 42.2 & 45 & 2.78 \\
2.83 & 35 & 40.4 & 45 & 4.36 \\
1.53 & 12 & 13 & 15 & 1.73
\end{tabular}


1

2 $\delta 13 C$ (V- $\delta 180 P 04$ (V- $\delta 180 C 03$ (VPDB) SMOW) SMOW)

\begin{tabular}{|c|c|c|c|c|c|}
\hline Rangifer tarandus & V.60.1561./m3 & Ságvár & -7.93 & 14.6 & NA \\
\hline Rangifer tarandus & V.60.1561./m2 & Ságvár & -9.67 & 12.3 & 22.7 \\
\hline Rangifer tarandus & V.60.1486. & Ságvár & -9.45 & 13.7 & 21.6 \\
\hline Rangifer tarandus & V.60.1532. & Ságvár & -10.46 & NA & 20.9 \\
\hline Megaloceros giganteus & V.64.859./1 & Tokod - Nagyberek & -12.39 & 11.1 & NA \\
\hline Megaloceros giganteus & V.64.859./2 & Tokod - Nagyberek & NA & 12.4 & NA \\
\hline Cervus elaphus & V.91.65. & Tokod - Nagyberek & NA & 14.2 & NA \\
\hline Cervus elaphus & V.92.17. & Tokod - Nagyberek & -9.07 & 14.8 & 21.3 \\
\hline Rangifer tarandus & V.63.1705. & Szeleta Cave & NA & 12.1 & NA \\
\hline Rangifer tarandus & V.63.1661. & Szeleta Cave & -4.20 & NA & 20.2 \\
\hline Alces alces & G.57.517. & Szeleta Cave & -11.75 & 14.8 & NA \\
\hline Rangifer tarandus & G.57.519. & Szeleta Cave & -0.37 & NA & 26 \\
\hline Cervus elaphus & V.58.1548. & Lambrecht Cave & -9.83 & 15.1 & NA \\
\hline Cervus elaphus & V.58.1078. & Lambrecht Cave & -9.95 & 14.4 & NA \\
\hline Cervus elaphus & V.58.1547./1 & Lambrecht Cave & -9.95 & 13 & 23.8 \\
\hline Cervus elaphus & V.58.1547./2 & Lambrecht Cave & -9.63 & 17.4 & 26.5 \\
\hline Cervus acoronatus & V.69.10./1 & Tarkő Rock-shelter & -9.88 & 14.1 & 23.1 \\
\hline Cervus acoronatus & V.69.12./1 & Tarkő Rock-shelter & NA & 13.4 & NA \\
\hline Cervus acoronatus & V.69.10./2 & Tarkő Rock-shelter & -10.85 & 15.9 & 24.2 \\
\hline Cervus acoronatus & V.69.12./2 & Tarkő Rock-shelter & -8.43 & 13.2 & 22.2 \\
\hline Cervus elaphus & V.60.1134. & Uppony I & NA & 15.4 & NA \\
\hline Cervus elaphus & V.60.1135. & Uppony I & -5.30 & 14.6 & 23.9 \\
\hline Cervus elaphus & V.60.1139. & Uppony I & -6.90 & 17.3 & 24.2 \\
\hline Cervus elaphus & V.60.1177. & Uppony I & -11.03 & 16.3 & 23.9 \\
\hline Cervus cf. elaphus & V.60.866. & Vár Cave & NA & 14.3 & NA \\
\hline Dama sp. & V.62.247. & Üröm Hill & -3.40 & 16.6 & 20.1 \\
\hline Dama sp. & V.62.233. & Üröm Hill & -6.06 & 14.5 & 20.9 \\
\hline Cervus sp. & V.59.994. & Gombasek & -9.70 & 13 & 21 \\
\hline Cervus sp. & V.59.946. & Gombasek & -10.79 & 14.2 & 21.3 \\
\hline Cervus sp. & V.59.1001./1 & Gombasek & -9.77 & 14.7 & 22.9 \\
\hline Cervus sp. & V.59.1001./2 & Gombasek & NA & 15.3 & NA \\
\hline
\end{tabular}




\begin{tabular}{ll}
$\begin{array}{c}\text { Calculated } \\
\text { environmental } \\
\text { water } \mathbf{8 1 8 0}\end{array}$ & $\begin{array}{c}\text { Calculated mean } \\
\text { annual } \\
\text { temperature }\end{array}$ \\
\hline-9.18 & 9.78 \\
-12.28 & 3.72 \\
-10.39 & 7.41 \\
NA & NA \\
-13.91 & 0.55 \\
-12.15 & 3.98 \\
-9.72 & 8.72 \\
-8.91 & 10.30 \\
-12.55 & 3.19 \\
NA & NA \\
-8.91 & 10.30 \\
NA & NA \\
-8.50 & 11.10 \\
-9.45 & 9.25 \\
-11.34 & 5.56 \\
-5.39 & 17.16 \\
-9.85 & 8.46 \\
-10.80 & 6.62 \\
-7.42 & 13.20 \\
-11.07 & 6.09 \\
-8.09 & 11.89 \\
-9.18 & 9.78 \\
-5.53 & 16.89 \\
-6.88 & 14.26 \\
-9.58 & 8.99 \\
-6.47 & 15.05 \\
-9.31 & 9.51 \\
-11.34 & 5.56 \\
-9.72 & 8.72 \\
-9.04 & 10.04 \\
-8.23 & 11.62 \\
&
\end{tabular}


1

\begin{tabular}{|c|c|c|c|}
\hline Locality & Species & ID & Facility \\
\hline Baradla Cave & Cervus elaphus & V.27070. & Natural History Museum \\
\hline Baradla Cave & Cervus elaphus & V.27070. & Natural History Museum \\
\hline Baradla Cave & Cervus elaphus & V.27070. & Natural History Museum \\
\hline Baradla Cave & Cervus elaphus & V.27070. & Natural History Museum \\
\hline Baradla Cave & Cervus elaphus & V.27070. & Natural History Museum \\
\hline Berva-völgy Cave & Cervus elaphus & V.63.1510. & Natural History Museum \\
\hline Berva-völgy Cave & Cervus elaphus & V.63.1510. & Natural History Museum \\
\hline Berva-völgy Cave & Cervus elaphus & V.63.1510. & Natural History Museum \\
\hline Berva-völgy Cave & Megaloceros giganteus & V.63.1514. & Natural History Museum \\
\hline Berva-völgy Cave & Megaloceros giganteus & V.63.1514. & Natural History Museum \\
\hline Gombasek & Alces sp. & V.59.877. & Natural History Museum \\
\hline Gombasek & Alces sp. & V.59.877. & Natural History Museum \\
\hline Gombasek & Alces sp. & V.59.877. & Natural History Museum \\
\hline Gombasek & Alces sp. & V.59.943. & Natural History Museum \\
\hline Gombasek & Alces sp. & V.59.943. & Natural History Museum \\
\hline Gombasek & Alces sp. & V.59.943. & Natural History Museum \\
\hline Gombasek & Alces sp. & V.59.957. & Natural History Museum \\
\hline Gombasek & Alces sp. & V.59.957. & Natural History Museum \\
\hline Gombasek & Alces sp. & V.59.958. & Natural History Museum \\
\hline Gombasek & Alces sp. & V.59.988. & Natural History Museum \\
\hline Gombasek & Capreolus sp. & V.59.1096. & Natural History Museum \\
\hline Gombasek & Capreolus sp. & V.59.1096. & Natural History Museum \\
\hline Gombasek & Capreolus sp. & V.59.1096. & Natural History Museum \\
\hline Gombasek & Capreolus sp. & V.60.1770. & Natural History Museum \\
\hline Gombasek & Capreolus sp. & V.60.1770. & Natural History Museum \\
\hline Gombasek & Capreolus sp. & V.60.1770. & Natural History Museum \\
\hline Gombasek & Capreolus sp. & V.60.1770. & Natural History Museum \\
\hline Gombasek & Capreolus sp. & V.60.1770. & Natural History Museum \\
\hline Gombasek & Capreolus sp. & V.60.1770. & Natural History Museum \\
\hline Gombasek & Cervus sp. & V.59.1001. & Natural History Museum \\
\hline Gombasek & Cervus sp. & V.59.1001. & Natural History Museum \\
\hline Gombasek & Cervus sp. & V.59.1001. & Natural History Museum \\
\hline Gombasek & Cervus sp. & V.59.1002. & Natural History Museum \\
\hline Gombasek & Cervus sp. & V.59.1002. & Natural History Museum \\
\hline Gombasek & Cervus sp. & V.59.1002. & Natural History Museum \\
\hline Gombasek & Cervus sp. & V.59.1002. & Natural History Museum \\
\hline Gombasek & Cervus sp. & V.59.875. & Natural History Museum \\
\hline Gombasek & Cervus sp. & V.59.875. & Natural History Museum \\
\hline Gombasek & Cervus sp. & V.59.875. & Natural History Museum \\
\hline Gombasek & Cervus sp. & V.59.875. & Natural History Museum \\
\hline Gombasek & Cervus sp. & V.59.936. & Natural History Museum \\
\hline Gombasek & Cervus sp. & V.59.936. & Natural History Museum \\
\hline Gombasek & Cervus sp. & V.59.937. & Natural History Museum \\
\hline Gombasek & Cervus sp. & V.59.944. & Natural History Museum \\
\hline Gombasek & Cervus sp. & V.59.944. & Natural History Museum \\
\hline Gombasek & Cervus sp. & V.59.944. & Natural History Museum \\
\hline
\end{tabular}




\begin{tabular}{|c|c|c|c|}
\hline Gombasek & Cervus sp. & V.59.946. & Natural History Museum \\
\hline Gombasek & Cervus sp. & V.59.946. & Natural History Museum \\
\hline Gombasek & Cervus sp. & V.59.946. & Natural History Museum \\
\hline Gombasek & Cervus sp. & V.59.946. & Natural History Museum \\
\hline Gombasek & Cervus sp. & V.59.956. & Natural History Museum \\
\hline Gombasek & Cervus sp. & V.59.956. & Natural History Museum \\
\hline Gombasek & Cervus sp. & V.59.956. & Natural History Museum \\
\hline Gombasek & Cervus sp. & V.59.956. & Natural History Museum \\
\hline Gombasek & Cervus sp. & V.59.970. & Natural History Museum \\
\hline Gombasek & Cervus sp. & V.59.980. & Natural History Museum \\
\hline Gombasek & Cervus sp. & V.59.983. & Natural History Museum \\
\hline Gombasek & Cervus sp. & V.59.989. & Natural History Museum \\
\hline Gombasek & Cervus sp. & V.59.989. & Natural History Museum \\
\hline Gombasek & Cervus sp. & V.59.989. & Natural History Museum \\
\hline Gombasek & Cervus sp. & V.59.989. & Natural History Museum \\
\hline Gombasek & Cervus sp. & V.59.989. & Natural History Museum \\
\hline Gombasek & Cervus sp. & V.59.989. & Natural History Museum \\
\hline Gombasek & Cervus sp. & V.59.989. & Natural History Museum \\
\hline Gombasek & Cervus sp. & V.59.994. & Natural History Museum \\
\hline Gombasek & Cervus sp. & V.60.1783. & Natural History Museum \\
\hline Gombasek & Cervus sp. & V.60.1783. & Natural History Museum \\
\hline Gombasek & Cervus sp. & V.60.1783. & Natural History Museum \\
\hline Gombasek & Cervus sp. & V.60.1783. & Natural History Museum \\
\hline Gombasek & Cervus sp. & V.60.1783. & Natural History Museum \\
\hline Gombasek & Cervus sp. & V.60.1783. & Natural History Museum \\
\hline Gombasek & Megaloceros sp. & V.59.927. & Natural History Museum \\
\hline Hórvölgy Rock-shelter & Cervus sp. & M.S.01. & Natural History Museum \\
\hline Hórvölgy Rock-shelter & Cervus sp. & M.S.02. & Natural History Museum \\
\hline Hórvölgy Rock-shelter & Cervus sp. & V.75.181. & Natural History Museum \\
\hline Hórvölgy Rock-shelter & Cervus sp. & V.75.181. & Natural History Museum \\
\hline Istállóskő Cave & Alces alces & V.59.379. & Natural History Museum \\
\hline Istállóskő Cave & Alces alces & V.59.379. & Natural History Museum \\
\hline Istállóskő Cave & Capreolus capreolus & V.59.30. & Natural History Museum \\
\hline Istállóskő Cave & Rangifer tarandus & V.59.389. & Natural History Museum \\
\hline Istállóskő Cave & Rangifer tarandus & V.59.394. & Natural History Museum \\
\hline Istállóskő Cave & Rangifer tarandus & V.59.408. & Natural History Museum \\
\hline Istállóskő Cave & Rangifer tarandus & V.59.408. & Natural History Museum \\
\hline Istállóskő Cave & Rangifer tarandus & V.59.421. & Natural History Museum \\
\hline Istállóskő Cave & Rangifer tarandus & V.59.424. & Natural History Museum \\
\hline Istállóskő Cave & Rangifer tarandus & V.59.424. & Natural History Museum \\
\hline Istállóskő Cave & Rangifer tarandus & V.59.428. & Natural History Museum \\
\hline Jankovich Cave & Rangifer tarandus & V.14659. & Natural History Museum \\
\hline Jankovich Cave & Rangifer tarandus & V.14659. & Natural History Museum \\
\hline Jankovich Cave & Rangifer tarandus & V.14659. & Natural History Museum \\
\hline Jankovich Cave & Rangifer tarandus & V.14659. & Natural History Museum \\
\hline Jankovich Cave & Rangifer tarandus & V.14660. & Natural History Museum \\
\hline Jankovich Cave & Rangifer tarandus & V.14660. & Natural History Museum \\
\hline Kiskevély Cave & Alces alces & V.60.956. & Natural History Museum \\
\hline
\end{tabular}




\begin{tabular}{|c|c|c|c|}
\hline Kiskevély Cave & Alces alces & V.60.956. & Natural History Museum \\
\hline Kiskevély Cave & Cervus elaphus & V.60.955. & Natural History Museum \\
\hline Kiskevély Cave & Cervus elaphus & V.60.955. & Natural History Museum \\
\hline Kiskőhát Cave & Rangifer tarandus & V.64.85. & Natural History Museum \\
\hline Kiskőhát Cave & Rangifer tarandus & V.64.85. & Natural History Museum \\
\hline Kiskőhát Cave & Rangifer tarandus & V.64.85. & Natural History Museum \\
\hline Lambrecht Cave & Alces alces & V.58.1030. & Natural History Museum \\
\hline Lambrecht Cave & Capreolus capreolus & V.58.1595. & Natural History Museum \\
\hline Lambrecht Cave & Capreolus capreolus & V.58.1596. & Natural History Museum \\
\hline Lambrecht Cave & Capreolus capreolus & V.58.1596. & Natural History Museum \\
\hline Lambrecht Cave & Capreolus capreolus & V.58.1596. & Natural History Museum \\
\hline Lambrecht Cave & Capreolus capreolus & V.58.1596. & Natural History Museum \\
\hline Lambrecht Cave & Capreolus capreolus & V.58.1611. & Natural History Museum \\
\hline Lambrecht Cave & Capreolus capreolus & V.58.1611. & Natural History Museum \\
\hline Lambrecht Cave & Capreolus capreolus & V.58.1611. & Natural History Museum \\
\hline Lambrecht Cave & Capreolus capreolus & V.58.1619. & Natural History Museum \\
\hline Lambrecht Cave & Capreolus capreolus & V.58.1619. & Natural History Museum \\
\hline Lambrecht Cave & Capreolus capreolus & V.58.1619. & Natural History Museum \\
\hline Lambrecht Cave & Capreolus capreolus & V.58.1619. & Natural History Museum \\
\hline Lambrecht Cave & Capreolus capreolus & V.58.1619. & Natural History Museum \\
\hline Lambrecht Cave & Cervus elaphus & V.58.1058. & Natural History Museum \\
\hline Lambrecht Cave & Cervus elaphus & V.58.1078. & Natural History Museum \\
\hline Lambrecht Cave & Cervus elaphus & V.58.1078. & Natural History Museum \\
\hline Lambrecht Cave & Cervus elaphus & V.58.1078. & Natural History Museum \\
\hline Lambrecht Cave & Cervus elaphus & V.58.1136. & Natural History Museum \\
\hline Lambrecht Cave & Cervus elaphus & V.58.1136. & Natural History Museum \\
\hline Lambrecht Cave & Cervus elaphus & V.58.1142. & Natural History Museum \\
\hline Lambrecht Cave & Cervus elaphus & V.58.1142. & Natural History Museum \\
\hline Lambrecht Cave & Cervus elaphus & V.58.1142. & Natural History Museum \\
\hline Lambrecht Cave & Cervus elaphus & V.58.1547. & Natural History Museum \\
\hline Lambrecht Cave & Cervus elaphus & V.58.1547. & Natural History Museum \\
\hline Lambrecht Cave & Cervus elaphus & V.58.1548. & Natural History Museum \\
\hline Lambrecht Cave & Cervus elaphus & V.58.1548. & Natural History Museum \\
\hline Lambrecht Cave & Cervus elaphus & V.58.1548. & Natural History Museum \\
\hline Lambrecht Cave & Cervus elaphus & V.58.1548. & Natural History Museum \\
\hline Lambrecht Cave & Cervus elaphus & V.58.720. & Natural History Museum \\
\hline Lambrecht Cave & Megaloceros giganteus & V.58.1030. & Natural History Museum \\
\hline Lambrecht Cave & Megaloceros giganteus & V.58.1063. & Natural History Museum \\
\hline Lambrecht Cave & Megaloceros giganteus & V.58.1063. & Natural History Museum \\
\hline Mogyorósbánya & Rangifer tarandus & 7476-7478 & Hungarian National Museum \\
\hline Mogyorósbánya & Rangifer tarandus & $7479-7481$ & Hungarian National Museum \\
\hline Mogyorósbánya & Rangifer tarandus & $7482-7485$ & Hungarian National Museum \\
\hline Mogyorósbánya & Rangifer tarandus & $7486-7488$ & Hungarian National Museum \\
\hline Mogyorósbánya & Rangifer tarandus & $7489-7491$ & Hungarian National Museum \\
\hline Mogyorósbánya & Rangifer tarandus & $7492-7494$ & Hungarian National Museum \\
\hline Mogyorósbánya & Rangifer tarandus & $7495-7497$ & Hungarian National Museum \\
\hline Osztramos 8. & Cervus sp. & V.73.70. & Natural History Museum \\
\hline Osztramos 8 & Cervus sp. & V.73.70. & Natural History Museum \\
\hline
\end{tabular}




\begin{tabular}{|c|c|c|c|}
\hline Osztramos 8. & Cervus sp. & V.73.70. & Natural History Museum \\
\hline Osztramos 8. & Cervus sp. & V.73.70. & Natural History Museum \\
\hline Osztramos 8. & Cervus sp. & V.73.70. & Natural History Museum \\
\hline Osztramos 8. & Cervus sp. & V.73.70. & Natural History Museum \\
\hline Osztramos 8. & Cervus sp. & V.73.70. & Natural History Museum \\
\hline Osztramos 8. & Cervus sp. & V.73.70. & Natural History Museum \\
\hline Osztramos 8. & Cervus sp. & V.73.70. & Natural History Museum \\
\hline Peskő Cave & Rangifer tarandus & V.14274. & Natural History Museum \\
\hline Peskő Cave & Rangifer tarandus & V.14274. & Natural History Museum \\
\hline Peskő Cave & Rangifer tarandus & V.14274. & Natural History Museum \\
\hline Peskő Cave & Rangifer tarandus & V.14277. & Natural History Museum \\
\hline Peskő Cave & Rangifer tarandus & V.14277. & Natural History Museum \\
\hline Peskő Cave & Rangifer tarandus & V.14277. & Natural History Museum \\
\hline Peskő Cave & Rangifer tarandus & V.14277. & Natural History Museum \\
\hline Peskő Cave & Rangifer tarandus & V.14277. & Natural History Museum \\
\hline Petényi Cave & Cervus elaphus & V.61.2021. & Natural History Museum \\
\hline Petényi Cave & Cervus elaphus & V.61.2021. & Natural History Museum \\
\hline Petényi Cave & Cervus elaphus & V.61.2021. & Natural History Museum \\
\hline Petényi Cave & Cervus elaphus & V.61.2021. & Natural History Museum \\
\hline Petényi Cave & Cervus elaphus & V.61.2025. & Natural History Museum \\
\hline Petényi Cave & Cervus elaphus & V.61.2025. & Natural History Museum \\
\hline Petényi Cave & Rangifer tarandus & V.61.2110. & Natural History Museum \\
\hline Petényi Cave & Rangifer tarandus & V.61.2110. & Natural History Museum \\
\hline Pilismarót & Rangifer tarandus & $7500-7502$ & Hungarian National Museum \\
\hline Pilismarót & Rangifer tarandus & 7503-7505 & Hungarian National Museum \\
\hline Pilismarót & Rangifer tarandus & 7503-7505 & Hungarian National Museum \\
\hline Pilismarót & Rangifer tarandus & $7506-7508$ & Hungarian National Museum \\
\hline Pilismarót & Rangifer tarandus & $7509-7511$ & Hungarian National Museum \\
\hline Pilismarót & Rangifer tarandus & $7512-7514$ & Hungarian National Museum \\
\hline Pilismarót & Rangifer tarandus & $7512-7514$ & Hungarian National Museum \\
\hline Pilismarót & Rangifer tarandus & $7515-7517$ & Hungarian National Museum \\
\hline Pilismarót & Rangifer tarandus & $7518-7520$ & Hungarian National Museum \\
\hline Pilismarót & Rangifer tarandus & $7521-7523$ & Hungarian National Museum \\
\hline Pilismarót & Rangifer tarandus & $7524-7526$ & Hungarian National Museum \\
\hline Pilismarót & Rangifer tarandus & $7527-7529$ & Hungarian National Museum \\
\hline Pilismarót & Rangifer tarandus & $7527-7529$ & Hungarian National Museum \\
\hline Pilismarót & Rangifer tarandus & $7530-7532$ & Hungarian National Museum \\
\hline Pilismarót & Rangifer tarandus & $7533-7535$ & Hungarian National Museum \\
\hline Pilismarót & Rangifer tarandus & $7536-7538$ & Hungarian National Museum \\
\hline Pilismarót & Rangifer tarandus & 7539-7541 & Hungarian National Museum \\
\hline Pilismarót & Rangifer tarandus & $7542-7544$ & Hungarian National Museum \\
\hline Pilismarót & Rangifer tarandus & $7545-7547$ & Hungarian National Museum \\
\hline Pilismarót & Rangifer tarandus & $7548-7550$ & Hungarian National Museum \\
\hline Pilismarót & Rangifer tarandus & 7551-7553 & Hungarian National Museum \\
\hline Pilismarót & Rangifer tarandus & 7554-7556 & Hungarian National Museum \\
\hline Pilismarót & Rangifer tarandus & $7557-7559$ & Hungarian National Museum \\
\hline Pilismarót & Rangifer tarandus & $7560-7562$ & Hungarian National Museum \\
\hline Pilismarót & Rangifer tarandus & $7563-7565$ & Hungarian National Museum \\
\hline
\end{tabular}


1

\begin{tabular}{|c|c|c|c|}
\hline Pilismarót & Rangifer tarandus & $7566-7568$ & Hungarian National Museum \\
\hline Pilismarót & Rangifer tarandus & 7569-7571 & Hungarian National Museum \\
\hline Pilismarót & Rangifer tarandus & $7572-7574$ & Hungarian National Museum \\
\hline Pilismarót & Rangifer tarandus & $7575-7577$ & Hungarian National Museum \\
\hline Pilismarót & Rangifer tarandus & $7578-7580$ & Hungarian National Museum \\
\hline Pilismarót & Rangifer tarandus & 7581-7583 & Hungarian National Museum \\
\hline Pilismarót & Rangifer tarandus & 7584-7586 & Hungarian National Museum \\
\hline Pilismarót & Rangifer tarandus & 7584-7586 & Hungarian National Museum \\
\hline Pilismarót & Rangifer tarandus & 7587-7589 & Hungarian National Museum \\
\hline Pilismarót & Rangifer tarandus & 7590-7592 & Hungarian National Museum \\
\hline Pilismarót & Rangifer tarandus & 7593-7595 & Hungarian National Museum \\
\hline Pilismarót & Rangifer tarandus & 7596-7598 & Hungarian National Museum \\
\hline Pilismarót & Rangifer tarandus & 7596-7598 & Hungarian National Museum \\
\hline Pilismarót & Rangifer tarandus & 7599-7601 & Hungarian National Museum \\
\hline Pilismarót & Rangifer tarandus & $7602-7604$ & Hungarian National Museum \\
\hline Pilismarót & Rangifer tarandus & $7605-7607$ & Hungarian National Museum \\
\hline Pilismarót & Rangifer tarandus & $7608-7610$ & Hungarian National Museum \\
\hline Pilismarót & Rangifer tarandus & 7611-7613 & Hungarian National Museum \\
\hline Pilismarót & Rangifer tarandus & 7614-7616 & Hungarian National Museum \\
\hline Pilismarót & Rangifer tarandus & 7617-7619 & Hungarian National Museum \\
\hline Pilismarót & Rangifer tarandus & 7617-7619 & Hungarian National Museum \\
\hline Pilismarót & Rangifer tarandus & $7620-7622$ & Hungarian National Museum \\
\hline Pilismarót & Rangifer tarandus & $7623-7625$ & Hungarian National Museum \\
\hline Pilismarót & Rangifer tarandus & $7626-7628$ & Hungarian National Museum \\
\hline Pilismarót & Rangifer tarandus & $7629-7631$ & Hungarian National Museum \\
\hline Pilismarót & Rangifer tarandus & $7632-7634$ & Hungarian National Museum \\
\hline Pilismarót & Rangifer tarandus & 7635-7637 & Hungarian National Museum \\
\hline Pilismarót & Rangifer tarandus & $7638-7641$ & Hungarian National Museum \\
\hline Pilismarót & Rangifer tarandus & $7642-7644$ & Hungarian National Museum \\
\hline Pilismarót & Rangifer tarandus & $7642-7644$ & Hungarian National Museum \\
\hline Pilismarót & Rangifer tarandus & $7645-7647$ & Hungarian National Museum \\
\hline Pilismarót & Rangifer tarandus & $7648-7650$ & Hungarian National Museum \\
\hline Pilismarót & Rangifer tarandus & $7651-7653$ & Hungarian National Museum \\
\hline Pilismarót & Rangifer tarandus & 7654-7656 & Hungarian National Museum \\
\hline Pilismarót & Rangifer tarandus & 7657-7659 & Hungarian National Museum \\
\hline Pilismarót & Rangifer tarandus & $7660-7662$ & Hungarian National Museum \\
\hline Pilismarót & Rangifer tarandus & $7663-7665$ & Hungarian National Museum \\
\hline Pilismarót & Rangifer tarandus & 7666-7668 & Hungarian National Museum \\
\hline Pilismarót & Rangifer tarandus & 7669-7671 & Hungarian National Museum \\
\hline Pilismarót & Rangifer tarandus & 7669-7671 & Hungarian National Museum \\
\hline Pilismarót & Rangifer tarandus & $7672-7674$ & Hungarian National Museum \\
\hline Pilismarót & Rangifer tarandus & $7675-7677$ & Hungarian National Museum \\
\hline Pilismarót & Rangifer tarandus & $7678-7680$ & Hungarian National Museum \\
\hline Pilismarót & Rangifer tarandus & $7678-7680$ & Hungarian National Museum \\
\hline Pilismarót & Rangifer tarandus & $7681-7683$ & Hungarian National Museum \\
\hline Pilismarót & Rangifer tarandus & $7681-7683$ & Hungarian National Museum \\
\hline Pilismarót & Rangifer tarandus & 7684-7686 & Hungarian National Museum \\
\hline Pilismarót & Rangifer tarandus & 7687-7689 & Hungarian National Museum \\
\hline
\end{tabular}




\begin{tabular}{|c|c|c|c|}
\hline Pilismarót & Rangifer tarandus & 7690-7692 & Hungarian National Museum \\
\hline Pilismarót & Rangifer tarandus & 7690-7692 & Hungarian National Museum \\
\hline Pilismarót & Rangifer tarandus & 7693-7695 & Hungarian National Museum \\
\hline Pilismarót & Rangifer tarandus & 7696-7698 & Hungarian National Museum \\
\hline Pilismarót & Rangifer tarandus & 7699-7701 & Hungarian National Museum \\
\hline Pilismarót & Rangifer tarandus & 7702-7704 & Hungarian National Museum \\
\hline Pilismarót & Rangifer tarandus & 7705-7707 & Hungarian National Museum \\
\hline Pilismarót & Rangifer tarandus & $7708-7710$ & Hungarian National Museum \\
\hline Pilismarót & Rangifer tarandus & 7711-7713 & Hungarian National Museum \\
\hline Pilismarót & Rangifer tarandus & 7711-7713 & Hungarian National Museum \\
\hline Pilismarót & Rangifer tarandus & 7714-7716 & Hungarian National Museum \\
\hline Pilismarót & Rangifer tarandus & 7717-7719 & Hungarian National Museum \\
\hline Pilismarót & Rangifer tarandus & 7720-7722 & Hungarian National Museum \\
\hline Pilismarót & Rangifer tarandus & $7723-7725$ & Hungarian National Museum \\
\hline Pilismarót & Rangifer tarandus & $7726-7728$ & Hungarian National Museum \\
\hline Pilismarót & Rangifer tarandus & 7729-7731 & Hungarian National Museum \\
\hline Pilismarót & Rangifer tarandus & 7732-7734 & Hungarian National Museum \\
\hline Pilismarót & Rangifer tarandus & $7735-7738$ & Hungarian National Museum \\
\hline Pilismarót & Rangifer tarandus & 7739-7741 & Hungarian National Museum \\
\hline Remete Cave & Cervus elaphus & V.61.1292. & Natural History Museum \\
\hline Remete Cave & Cervus elaphus & V.61.1292. & Natural History Museum \\
\hline Remete Cave & Cervus elaphus & V.61.1292. & Natural History Museum \\
\hline Ságvár & Rangifer tarandus & V.60.1486. & Natural History Museum \\
\hline Ságvár & Rangifer tarandus & V.60.1503. & Natural History Museum \\
\hline Ságvár & Rangifer tarandus & V.60.1532. & Natural History Museum \\
\hline Ságvár & Rangifer tarandus & V.60.1559. & Natural History Museum \\
\hline Ságvár & Rangifer tarandus & V.60.1559. & Natural History Museum \\
\hline Ságvár & Rangifer tarandus & V.60.1561. & Natural History Museum \\
\hline Ságvár & Rangifer tarandus & V.60.1561. & Natural History Museum \\
\hline Ságvár & Rangifer tarandus & V.60.1561. & Natural History Museum \\
\hline Ságvár & Rangifer tarandus & V.60.1561. & Natural History Museum \\
\hline Ságvár & Rangifer tarandus & V.60.1561. & Natural History Museum \\
\hline Ságvár & Rangifer tarandus & V.60.1561. & Natural History Museum \\
\hline Szeleta Cave & Rangifer tarandus & V.63.1661. & Natural History Museum \\
\hline Szeleta Cave & Rangifer tarandus & V.63.1661. & Natural History Museum \\
\hline Szeleta Cave & Rangifer tarandus & V.63.1661. & Natural History Museum \\
\hline Szeleta Cave & Rangifer tarandus & V.63.1661. & Natural History Museum \\
\hline Szeleta Cave & Rangifer tarandus & V.63.1661. & Natural History Museum \\
\hline Szeleta Cave & Rangifer tarandus & V.63.1661. & Natural History Museum \\
\hline Szeleta Cave & Rangifer tarandus & V.63.1661. & Natural History Museum \\
\hline Szeleta Cave & Rangifer tarandus & V.63.1705. & Natural History Museum \\
\hline Szeleta Cave & Rangifer tarandus & V.63.1705. & Natural History Museum \\
\hline Szeleta Cave & Rangifer tarandus & V.63.1705. & Natural History Museum \\
\hline Szeleta Cave & Rangifer tarandus & V.63.1705. & Natural History Museum \\
\hline Szeleta Cave & Rangifer tarandus & V.63.1705. & Natural History Museum \\
\hline Szeleta Cave & Rangifer tarandus & V.63.1705. & Natural History Museum \\
\hline Szeleta Cave & Rangifer tarandus & V.63.1705. & Natural History Museum \\
\hline Szeleta Cave & Rangifer tarandus & V.63.1705. & Natural History Museum \\
\hline
\end{tabular}




\begin{tabular}{|c|c|c|c|}
\hline Szelim Cave & Alces alces & G.57.227. & Natural History Museum \\
\hline Szelim Cave & Alces alces & G.57.504. & Natural History Museum \\
\hline Szelim Cave & Alces alces & G.57.517. & Natural History Museum \\
\hline Szelim Cave & Alces alces & G.57.519. & Natural History Museum \\
\hline Szelim Cave & Alces alces & G.57.675. & Natural History Museum \\
\hline Szelim Cave & Alces alces & G.57.675. & Natural History Museum \\
\hline Szelim Cave & Cervus elaphus & G.57.386. & Natural History Museum \\
\hline Szelim Cave & Cervus elaphus & G.57.386. & Natural History Museum \\
\hline Szelim Cave & Cervus elaphus & G.57.386. & Natural History Museum \\
\hline Szelim Cave & Cervus elaphus & G.57.451. & Natural History Museum \\
\hline Szelim Cave & Rangifer tarandus & G.57.101. & Natural History Museum \\
\hline Szelim Cave & Rangifer tarandus & G.57.507. & Natural History Museum \\
\hline Szelim Cave & Rangifer tarandus & G.57.588. & Natural History Museum \\
\hline Szelim Cave & Rangifer tarandus & G.57.588. & Natural History Museum \\
\hline Szelim Cave & Rangifer tarandus & G.57.594. & Natural History Museum \\
\hline Szelim Cave & Rangifer tarandus & G.57.594. & Natural History Museum \\
\hline Szelim Cave & Rangifer tarandus & G.57.594. & Natural History Museum \\
\hline Szelim Cave & Rangifer tarandus & G.57.594. & Natural History Museum \\
\hline Szelim Cave & Rangifer tarandus & G.57.594. & Natural History Museum \\
\hline Szelim Cave & Rangifer tarandus & G.57.617. & Natural History Museum \\
\hline Szelim Cave & Rangifer tarandus & G.57.617. & Natural History Museum \\
\hline Szelim Cave & Rangifer tarandus & G.57.617. & Natural History Museum \\
\hline Szelim Cave & Rangifer tarandus & G.57.621. & Natural History Museum \\
\hline Szelim Cave & Rangifer tarandus & G.57.621. & Natural History Museum \\
\hline Szelim Cave & Rangifer tarandus & G.57.625. & Natural History Museum \\
\hline Szelim Cave & Rangifer tarandus & G.57.628. & Natural History Museum \\
\hline Szelim Cave & Rangifer tarandus & G.57.659. & Natural History Museum \\
\hline Szelim Cave & Rangifer tarandus & G.57.659. & Natural History Museum \\
\hline Szelim Cave & Rangifer tarandus & G.57.659. & Natural History Museum \\
\hline Szelim Cave & Rangifer tarandus & G.57.660. & Natural History Museum \\
\hline Szuhogy - Csorbakő & Megaloceros giganteus & V.63.1578. & Natural History Museum \\
\hline Szuhogy - Csorbakő & Rangifer tarandus & V.60.1104. & Natural History Museum \\
\hline Tapolca Cave & Cervus elaphus & V.63.1496. & Natural History Museum \\
\hline Tapolca Cave & Megaloceros giganteus & V.63.1442. & Natural History Museum \\
\hline Tapolca Cave & Megaloceros giganteus & V.63.1445. & Natural History Museum \\
\hline Tapolca Cave & Megaloceros giganteus & V.63.1482. & Natural History Museum \\
\hline Tarkő Rock-shelter & Cervus acoronatus & V.69.10. & Natural History Museum \\
\hline Tarkő Rock-shelter & Cervus acoronatus & V.69.10. & Natural History Museum \\
\hline Tarkő Rock-shelter & Cervus acoronatus & V.69.12. & Natural History Museum \\
\hline Tarkő Rock-shelter & Cervus acoronatus & V.69.12. & Natural History Museum \\
\hline Tokod - Nagyberek I & Cervus elaphus & V.64.867. & Natural History Museum \\
\hline Tokod - Nagyberek I & Cervus elaphus & V.91.65. & Natural History Museum \\
\hline Tokod - Nagyberek I & Cervus elaphus & V.92.17. & Natural History Museum \\
\hline Tokod - Nagyberek I & Megaloceros giganteus & V.64.859. & Natural History Museum \\
\hline Tokod - Nagyberek I & Megaloceros giganteus & V.64.859. & Natural History Museum \\
\hline Uppony I & Cervus sp. & V.60.1131. & Natural History Museum \\
\hline Uppony I & Cervus sp. & V.60.1133. & Natural History Museum \\
\hline Uppony I & Cervus sp. & V.60.1133. & Natural History Museum \\
\hline
\end{tabular}




\begin{tabular}{|c|c|c|c|}
\hline Uppony I & Cervus sp. & V.60.1135. & Natural History Museum \\
\hline Uppony I & Cervus sp. & V.60.1139. & Natural History Museum \\
\hline Uppony I & Cervus sp. & V.60.1177. & Natural History Museum \\
\hline Uppony I & Cervus sp. & V.60.1278. & Natural History Museum \\
\hline Uppony I & Cervus sp. & V.65.174. & Natural History Museum \\
\hline Uppony I & Cervus sp. & V.60.1134. & Natural History Museum \\
\hline Üröm Hill & Dama sp. & V.62.233. & Natural History Museum \\
\hline Üröm Hill & Dama sp. & V.62.233. & Natural History Museum \\
\hline Üröm Hill & Dama sp. & V.62.233. & Natural History Museum \\
\hline Üröm Hill & Dama sp. & V.62.233. & Natural History Museum \\
\hline Üröm Hill & Dama sp. & V.62.233. & Natural History Museum \\
\hline Üröm Hill & Dama sp. & V.62.233. & Natural History Museum \\
\hline Üröm Hill & Dama sp. & V.62.247. & Natural History Museum \\
\hline Vár Cave & Cervus cf. elaphus & V.60.866. & Natural History Museum \\
\hline Vár Cave & Cervus cf. elaphus & V.60.867. & Natural History Museum \\
\hline Vár Cave & Cervus cf. elaphus & V.77.54. & Natural History Museum \\
\hline Vértesszőllős II & Cervus sp. & V.2010.37.1. & Natural History Museum \\
\hline Vértesszőllős II & Cervus sp. & V.69.791. & Natural History Museum \\
\hline Vértesszőllős II & Cervus sp. & V.69.791. & Natural History Museum \\
\hline Vértesszőllős II & Cervus sp. & V.69.791. & Natural History Museum \\
\hline Vértesszőllős II & Cervus sp. & V.69.792. & Natural History Museum \\
\hline Vértesszőllős II & Cervus sp. & V.69.793. & Natural History Museum \\
\hline Vértesszőllős II & Cervus sp. & V.69.794. & Natural History Museum \\
\hline Vértesszőllős II & Cervus sp. & V.69.794. & Natural History Museum \\
\hline Zalaegerszeg & Megaloceros giganteus & V.62.103. & Natural History Museum \\
\hline Zalaegerszeg & Megaloceros giganteus & V.62.103. & Natural History Museum \\
\hline Zalaegerszeg & Megaloceros giganteus & V.62.103. & Natural History Museum \\
\hline Zebegény & Cervus elaphus & V.61.2364. & Natural History Museum \\
\hline Zebegény & Cervus elaphus & V.61.2364. & Natural History Museum \\
\hline Zebegény & Cervus elaphus & V.61.2364. & Natural History Museum \\
\hline Ságvár & Rangifer tarandus & V.60.1435./1 & Natural History Museum \\
\hline Ságvár & Rangifer tarandus & V.60.1435./2 & Natural History Museum \\
\hline Ságvár & Rangifer tarandus & V.60.1437. & Natural History Museum \\
\hline Ságvár & Rangifer tarandus & V.60.1445./1 & Natural History Museum \\
\hline Ságvár & Rangifer tarandus & V.60.1445./2 & Natural History Museum \\
\hline Ságvár & Rangifer tarandus & V.60.1450./1 & Natural History Museum \\
\hline Ságvár & Rangifer tarandus & V.60.1450./2 & Natural History Museum \\
\hline Ságvár & Rangifer tarandus & V.60.1450./3 & Natural History Museum \\
\hline Ságvár & Rangifer tarandus & V.60.1452./1 & Natural History Museum \\
\hline Ságvár & Rangifer tarandus & V.60.1452./2 & Natural History Museum \\
\hline Ságvár & Rangifer tarandus & V.60.1452./3 & Natural History Museum \\
\hline Ságvár & Rangifer tarandus & V.60.1469./1 & Natural History Museum \\
\hline Ságvár & Rangifer tarandus & V.60.1469./2 & Natural History Museum \\
\hline Ságvár & Rangifer tarandus & V.60.1489./1 & Natural History Museum \\
\hline Ságvár & Rangifer tarandus & V.60.1489./2 & Natural History Museum \\
\hline Ságvár & Rangifer tarandus & V.60.1489./3 & Natural History Museum \\
\hline Ságvár & Rangifer tarandus & V.60.1490./1 & Natural History Museum \\
\hline Ságvár & Rangifer tarandus & V.60.1490./2 & Natural History Museum \\
\hline
\end{tabular}




\begin{tabular}{|c|c|c|c|}
\hline Ságvár & Rangifer tarandus & V.60.1490./3 & Natural History Museum \\
\hline Ságvár & Rangifer tarandus & V.60.1493./1 & Natural History Museum \\
\hline Ságvár & Rangifer tarandus & V.60.1493./2 & Natural History Museum \\
\hline Ságvár & Rangifer tarandus & V.60.1496./1 & Natural History Museum \\
\hline Ságvár & Rangifer tarandus & V.60.1496./2 & Natural History Museum \\
\hline Ságvár & Rangifer tarandus & V.60.1496./3 & Natural History Museum \\
\hline Ságvár & Rangifer tarandus & V.60.1498./1 & Natural History Museum \\
\hline Ságvár & Rangifer tarandus & V.60.1498./2 & Natural History Museum \\
\hline Ságvár & Rangifer tarandus & V.60.1498./3 & Natural History Museum \\
\hline Ságvár & Rangifer tarandus & V.60.1501./1 & Natural History Museum \\
\hline Ságvár & Rangifer tarandus & V.60.1501./2 & Natural History Museum \\
\hline Ságvár & Rangifer tarandus & V.60.1501./3 & Natural History Museum \\
\hline Ságvár & Rangifer tarandus & V.60.1501./4 & Natural History Museum \\
\hline Ságvár & Rangifer tarandus & V.60.1503./1 & Natural History Museum \\
\hline Ságvár & Rangifer tarandus & V.60.1503./2 & Natural History Museum \\
\hline Ságvár & Rangifer tarandus & V.60.1503./3 & Natural History Museum \\
\hline Ságvár & Rangifer tarandus & V.60.1503./4 & Natural History Museum \\
\hline Ságvár & Rangifer tarandus & V.60.1503./5 & Natural History Museum \\
\hline Ságvár & Rangifer tarandus & V.60.1503./6 & Natural History Museum \\
\hline Ságvár & Rangifer tarandus & V.60.1503./7 & Natural History Museum \\
\hline Ságvár & Rangifer tarandus & V.60.1503./8 & Natural History Museum \\
\hline Ságvár & Rangifer tarandus & V.60.1504./1 & Natural History Museum \\
\hline Ságvár & Rangifer tarandus & V.60.1504./2 & Natural History Museum \\
\hline Ságvár & Rangifer tarandus & V.60.1505./1 & Natural History Museum \\
\hline Ságvár & Rangifer tarandus & V.60.1505./2 & Natural History Museum \\
\hline Ságvár & Rangifer tarandus & V.60.1507./1 & Natural History Museum \\
\hline Ságvár & Rangifer tarandus & V.60.1507./2 & Natural History Museum \\
\hline Ságvár & Rangifer tarandus & V.60.1508./1 & Natural History Museum \\
\hline Ságvár & Rangifer tarandus & V.60.1508./2 & Natural History Museum \\
\hline Ságvár & Rangifer tarandus & V.60.1508./3 & Natural History Museum \\
\hline Ságvár & Rangifer tarandus & V.60.1509. & Natural History Museum \\
\hline Ságvár & Rangifer tarandus & V.60.1510. & Natural History Museum \\
\hline Ságvár & Rangifer tarandus & V.60.1511./1 & Natural History Museum \\
\hline Ságvár & Rangifer tarandus & V.60.1511./2 & Natural History Museum \\
\hline Ságvár & Rangifer tarandus & V.60.1523. & Natural History Museum \\
\hline Ságvár & Rangifer tarandus & V.60.1524./1 & Natural History Museum \\
\hline Ságvár & Rangifer tarandus & V.60.1524./2 & Natural History Museum \\
\hline Ságvár & Rangifer tarandus & V.60.1526. & Natural History Museum \\
\hline Ságvár & Rangifer tarandus & V.60.1527. & Natural History Museum \\
\hline Ságvár & Rangifer tarandus & V.60.1528./1 & Natural History Museum \\
\hline Ságvár & Rangifer tarandus & V.60.1528./10 & Natural History Museum \\
\hline Ságvár & Rangifer tarandus & V.60.1528./11 & Natural History Museum \\
\hline Ságvár & Rangifer tarandus & V.60.1528./12 & Natural History Museum \\
\hline Ságvár & Rangifer tarandus & V.60.1528./2 & Natural History Museum \\
\hline Ságvár & Rangifer tarandus & V.60.1528./3 & Natural History Museum \\
\hline Ságvár & Rangifer tarandus & V.60.1528./4 & Natural History Museum \\
\hline Ságvár & Rangifer tarandus & V.60.1528./5 & Natural History Museum \\
\hline Ságvár & Rangifer tarandus & V.60.1528./6 & Natural History Museum \\
\hline
\end{tabular}




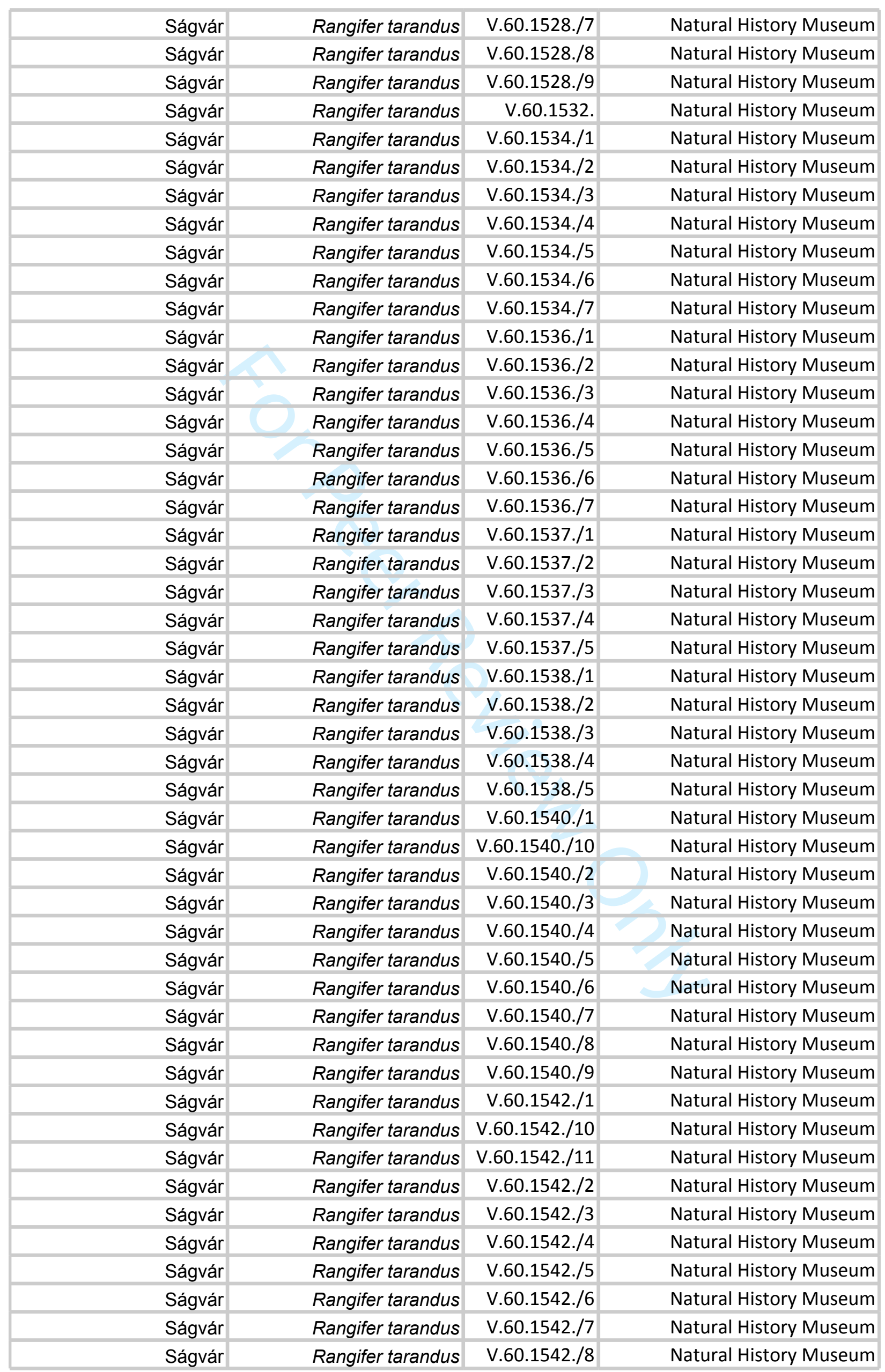




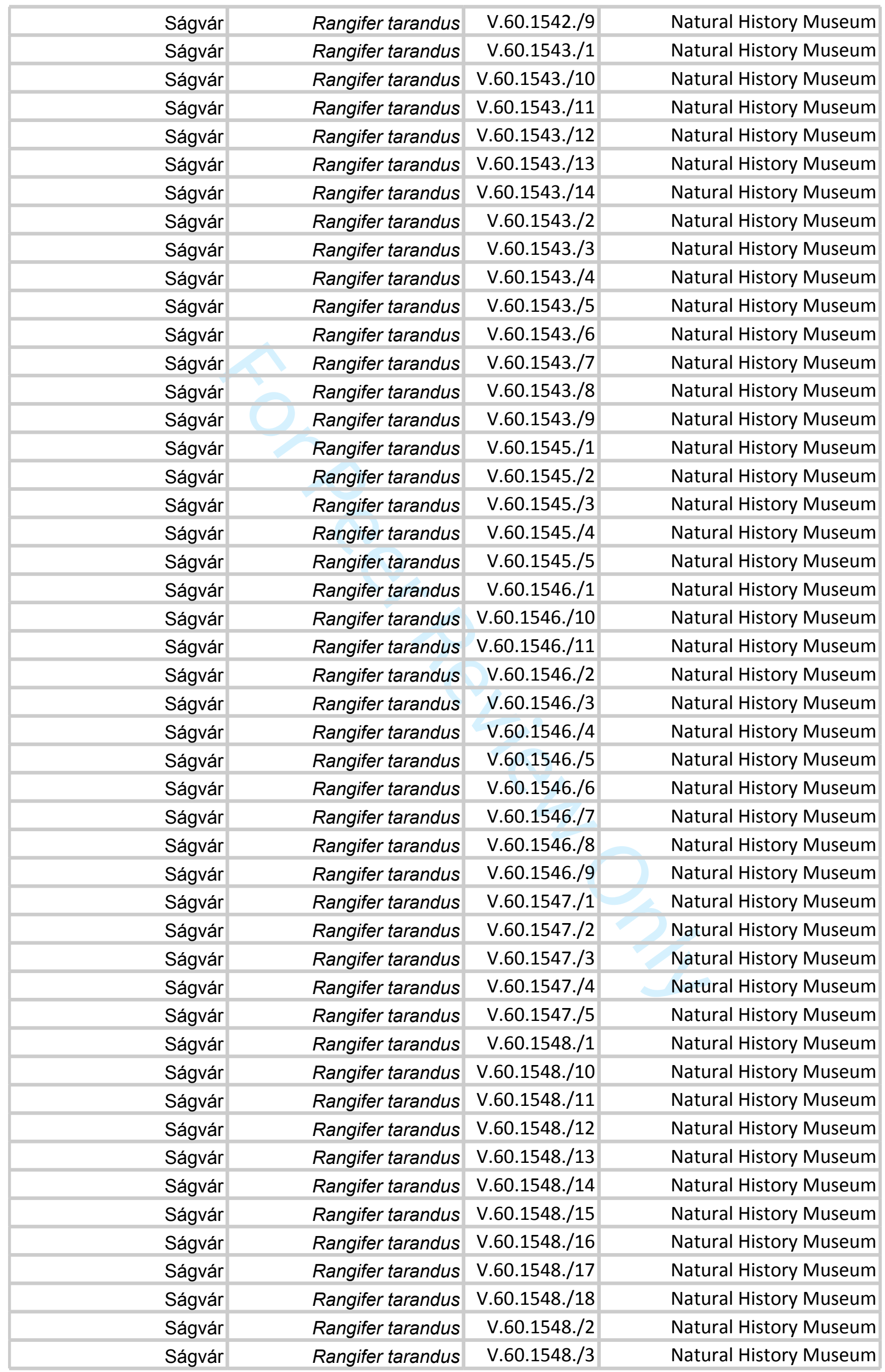




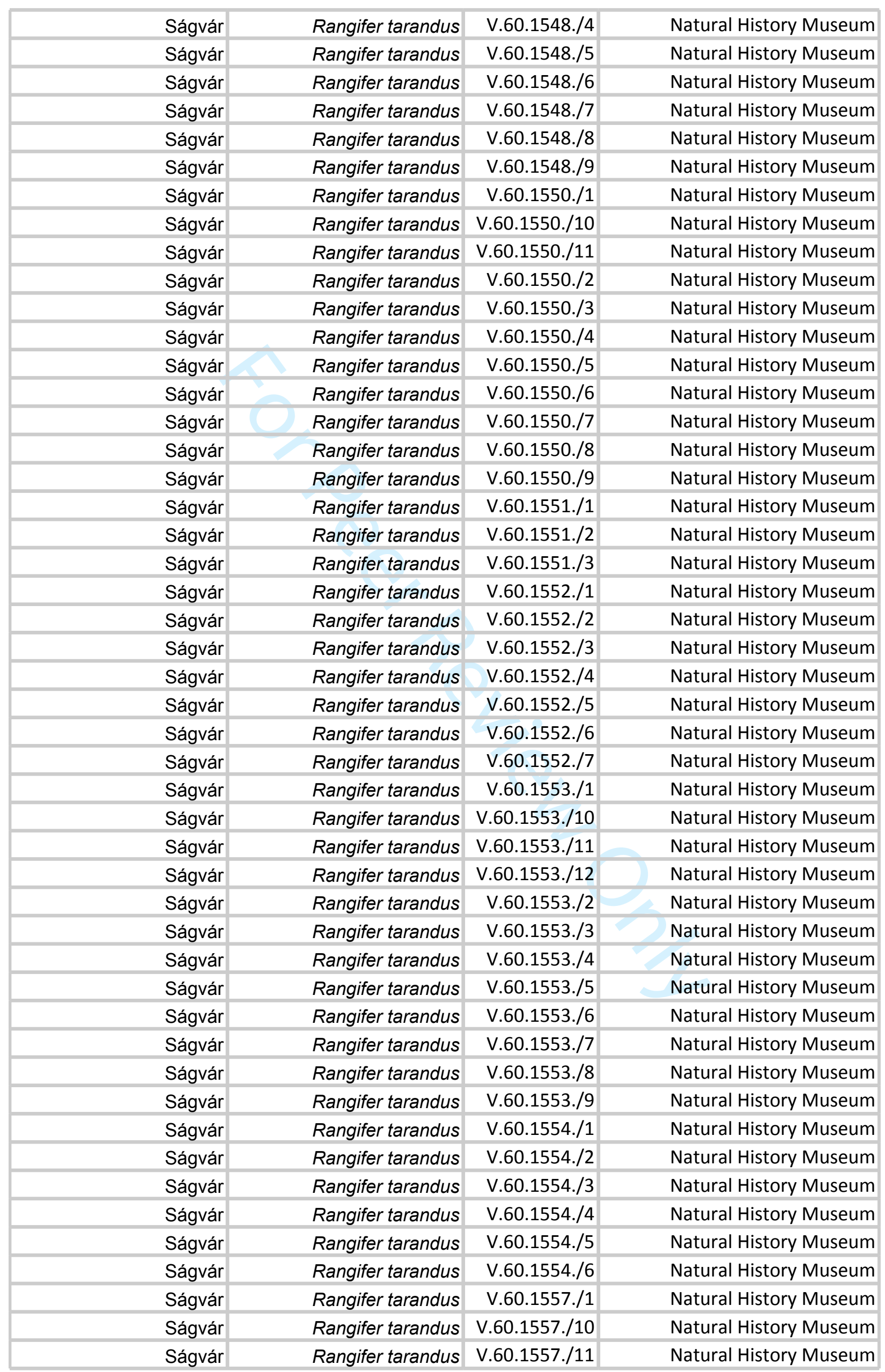




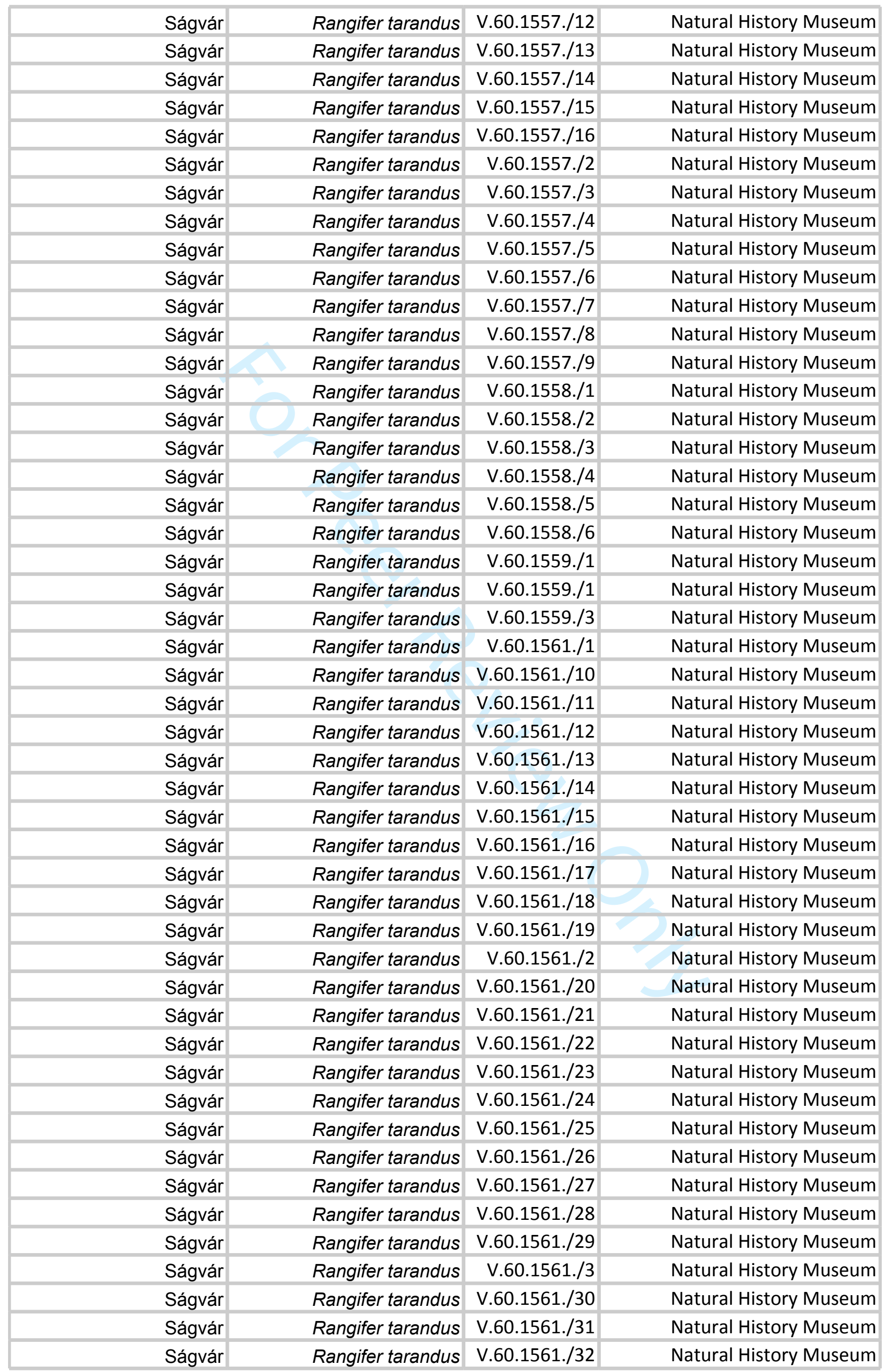




\begin{tabular}{|c|c|c|c|}
\hline Ságvár & Rangifer tarandus & V.60.1561./33 & Natural History Museum \\
\hline Ságvár & Rangifer tarandus & V.60.1561./34 & Natural History Museum \\
\hline Ságvár & Rangifer tarandus & V.60.1561./35 & Natural History Museum \\
\hline Ságvár & Rangifer tarandus & V.60.1561./36 & Natural History Museum \\
\hline Ságvár & Rangifer tarandus & V.60.1561./37 & Natural History Museum \\
\hline Ságvár & Rangifer tarandus & V.60.1561./38 & Natural History Museum \\
\hline Ságvár & Rangifer tarandus & V.60.1561./39 & Natural History Museum \\
\hline Ságvár & Rangifer tarandus & V.60.1561./4 & Natural History Museum \\
\hline Ságvár & Rangifer tarandus & V.60.1561./40 & Natural History Museum \\
\hline Ságvár & Rangifer tarandus & V.60.1561./41 & Natural History Museum \\
\hline Ságvár & Rangifer tarandus & V.60.1561./42 & Natural History Museum \\
\hline Ságvár & Rangifer tarandus & V.60.1561./43 & Natural History Museum \\
\hline Ságvár & Rangifer tarandus & V.60.1561./44 & Natural History Museum \\
\hline Ságvár & Rangifer tarandus & V.60.1561./5 & Natural History Museum \\
\hline Ságvár & Rangifer tarandus & V.60.1561./6 & Natural History Museum \\
\hline Ságvár & Rangifer tarandus & V.60.1561./7 & Natural History Museum \\
\hline Ságvár & Rangifer tarandus & V.60.1561./8 & Natural History Museum \\
\hline Ságvár & Rangifer tarandus & V.60.1561./9 & Natural History Museum \\
\hline Ságvár & Rangifer tarandus & $4 / 9 / 1 / 1$ & Hungarian National Museum \\
\hline Ságvár & Rangifer tarandus & $4 / 9 / 1 / 2$ & Hungarian National Museum \\
\hline Ságvár & Rangifer tarandus & $4 / 9 / 1 / 3$ & Hungarian National Museum \\
\hline Ságvár & Rangifer tarandus & $4 / 9 / 2 / 1$ & Hungarian National Museum \\
\hline Ságvár & Rangifer tarandus & $4 / 9 / 3 / 1$ & Hungarian National Museum \\
\hline Ságvár & Rangifer tarandus & $4 / 9 / 3 / 2$ & Hungarian National Museum \\
\hline Ságvár & Rangifer tarandus & $4 / 9 / 3 / 3$ & Hungarian National Museum \\
\hline Ságvár & Rangifer tarandus & $4 / 9 / 3 / 4$ & Hungarian National Museum \\
\hline Ságvár & Rangifer tarandus & $4 / 9 / 3 / 5$ & Hungarian National Museum \\
\hline Ságvár & Rangifer tarandus & $4 / 9 / 3 / 6$ & Hungarian National Museum \\
\hline Ságvár & Rangifer tarandus & $4 / 9 / 3 / 7$ & Hungarian National Museum \\
\hline Ságvár & Rangifer tarandus & $4 / 9 / 3 / 8$ & Hungarian National Museum \\
\hline Ságvár & Rangifer tarandus & $4 / 9 / 3 / 9$ & Hungarian National Museum \\
\hline Ságvár & Rangifer tarandus & $4 / 9 / 3 / 10$ & Hungarian National Museum \\
\hline Ságvár & Rangifer tarandus & $4 / 9 / 3 / 11$ & Hungarian National Museum \\
\hline Ságvár & Rangifer tarandus & $4 / 9 / 3 / 12$ & Hungarian National Museum \\
\hline Ságvár & Rangifer tarandus & $4 / 9 / 3 / 13$ & Hungarian National Museum \\
\hline Ságvár & Rangifer tarandus & $4 / 9 / 3 / 14$ & Hungarian National Museum \\
\hline Ságvár & Rangifer tarandus & $4 / 9 / 3 / 15$ & Hungarian National Museum \\
\hline Ságvár & Rangifer tarandus & $4 / 9 / 3 / 16$ & Hungarian National Museum \\
\hline Ságvár & Rangifer tarandus & $4 / 9 / 3 / 17$ & Hungarian National Museum \\
\hline Ságvár & Rangifer tarandus & $4 / 9 / 6 / 1$ & Hungarian National Museum \\
\hline Ságvár & Rangifer tarandus & $4 / 9 / 6 / 2$ & Hungarian National Museum \\
\hline Ságvár & Rangifer tarandus & $4 / 9 / 6 / 3$ & Hungarian National Museum \\
\hline Ságvár & Rangifer tarandus & $4 / 9 / 6 / 4$ & Hungarian National Museum \\
\hline Ságvár & Rangifer tarandus & $4 / 9 / 7 / 1$ & Hungarian National Museum \\
\hline Ságvár & Rangifer tarandus & $4 / 9 / 7 / 2$ & Hungarian National Museum \\
\hline Ságvár & Rangifer tarandus & $4 / 9 / 7 / 3$ & Hungarian National Museum \\
\hline Ságvár & Rangifer tarandus & $4 / 9 / 7 / 4$ & Hungarian National Museum \\
\hline Ságvár & Rangifer tarandus & $4 / 9 / 7 / 5$ & Hungarian National Museum \\
\hline
\end{tabular}




\begin{tabular}{|r|r|r|r|}
\hline Ságvár & Rangifer tarandus & $4 / 9 / 7 / 6$ & Hungarian National Museum \\
\hline Ságvár & Rangifer tarandus & $4 / 9 / 7 / 7$ & Hungarian National Museum \\
\hline Ságvár & Rangifer tarandus & $4 / 9 / 7 / 8$ & Hungarian National Museum \\
\hline Ságvár & Rangifer tarandus & $4 / 9 / 7 / 9$ & Hungarian National Museum \\
\hline Ságvár & Rangifer tarandus & $4 / 9 / 7 / 10$ & Hungarian National Museum \\
\hline Ságvár & Rangifer tarandus & $4 / 9 / 7 / 11$ & Hungarian National Museum \\
\hline Ságvár & Rangifer tarandus & $4 / 9 / 7 / 12$ & Hungarian National Museum \\
\hline Ságvár & Rangifer tarandus & $4 / 9 / 7 / 13$ & Hungarian National Museum \\
\hline Ságvár & Rangifer tarandus & $4 / 9 / 7 / 14$ & Hungarian National Museum \\
\hline Ságvár & Rangifer tarandus & $4 / 9 / 7 / 15$ & Hungarian National Museum \\
\hline Ságvár & Rangifer tarandus & $4 / 9 / 7 / 16$ & Hungarian National Museum \\
\hline Ságvár & Rangifer tarandus & $4 / 9 / 7 / 17$ & Hungarian National Museum \\
\hline Ságvár & Rangifer tarandus & $4 / 9 / 7 / 18$ & Hungarian National Museum \\
\hline Ságvár & Rangifer tarandus & $4 / 9 / 7 / 19$ & Hungarian National Museum \\
\hline Ságvár & Rangifer tarandus & $4 / 9 / 9 / 1$ & Hungarian National Museum \\
\hline Ságvár & Rangifer tarandus & $4 / 9 / 9 / 2$ & Hungarian National Museum \\
\hline Ságvár & Rangifer tarandus & $4 / 9 / 9 / 3$ & Hungarian National Museum \\
\hline Ságvár & Rangifer tarandus & $4 / 9 / 9 / 4$ & Hungarian National Museum \\
\hline Ságvár & Rangifer tarandus & $4 / 9 / 9 / 5$ & Hungarian National Museum \\
\hline Ságvár & Rangifer tarandus & $4 / 9 / 9 / 6$ & Hungarian National Museum \\
\hline Ságvár & Rangifer tarandus & $4 / 9 / 9 / 7$ & Hungarian National Museum \\
\hline Ságvár & Rangifer tarandus & $4 / 9 / 9 / 8$ & Hungarian National Museum \\
\hline Ságvár & Rangifer tarandus & $4 / 9 / 9 / 9$ & Hungarian National Museum \\
\hline Ságvár & Rangifer tarandus & $4 / 9 / 9 / 10$ & Hungarian National Museum \\
\hline Ságvár & Rangifer tarandus & $4 / 9 / 9 / 11$ & Hungarian National Museum \\
\hline & & & \\
\hline & & & \\
\hline & & &
\end{tabular}




\begin{tabular}{|c|c|c|c|c|}
\hline \multirow{2}{*}{ Mesowear score } & \multicolumn{2}{|c|}{ Microwear } & \multicolumn{2}{|r|}{ Stable isotopi } \\
\hline & Scratch (mean) & Pit (mean) & 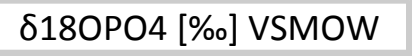 & 8180CO3 [\%o] VPDB \\
\hline 1 & 16.7 & 20.2 & - & - \\
\hline 4 & 25.3 & 29.6 & - & - \\
\hline 5 & - & - & - & - \\
\hline 4 & - & - & - & - \\
\hline 3 & - & - & - & - \\
\hline 1 & - & - & - & 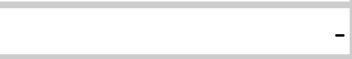 \\
\hline 4 & - & - & - & - \\
\hline 3 & - & - & - & - \\
\hline 3 & 24.2 & 31 & - & - \\
\hline 2 & - & - & - & - \\
\hline 2 & $\Delta$ & - & - & - \\
\hline 2 & - & - & - & 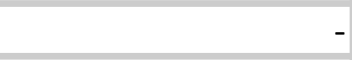 \\
\hline 1 & - & - & - & - \\
\hline 2 & - & - & - & - \\
\hline 5 & - & - & - & - \\
\hline 1 & - & - & - & - \\
\hline 3 & 16 & $N$ & - & - \\
\hline 1 & - & $(N)$ & - & - \\
\hline 2 & - & 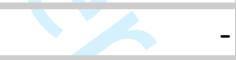 & - & 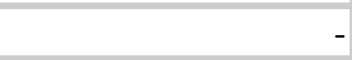 \\
\hline 5 & 17 & 14 & - & - \\
\hline 1 & - & $5-$ & - & - \\
\hline 1 & - & - & - & 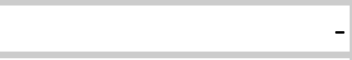 \\
\hline 1 & - & - & 8 & 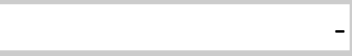 \\
\hline 5 & 9.4 & 30.6 & 20 & - \\
\hline 5 & - & - & 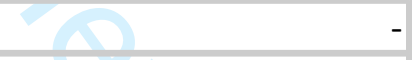 & - \\
\hline 5 & - & - & $+p$ & - \\
\hline 5 & - & - & 2 & 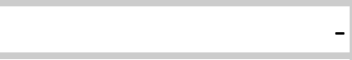 \\
\hline 5 & - & - & $=$ & - \\
\hline 5 & - & - & - & \\
\hline 2 & - & - & 14.7 & -7.7 \\
\hline 2 & - & - & 15.3 & NA \\
\hline 2 & - & - & - & 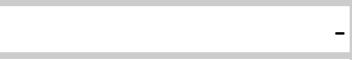 \\
\hline 0 & - & - & - & - \\
\hline 0 & - & - & - & - \\
\hline 2 & - & - & - & - \\
\hline 2 & - & - & - & - \\
\hline 5 & - & - & - & \\
\hline 0 & - & - & - & - \\
\hline 0 & - & - & - & - \\
\hline 4 & - & - & - & - \\
\hline 2 & - & - & - & - \\
\hline 2 & - & - & - & \\
\hline 5 & - & - & - & $=$ \\
\hline 2 & 27.3 & 23.5 & - & - \\
\hline 4 & 26 & 27 & - & - \\
\hline 2 & - & - & - & - \\
\hline
\end{tabular}




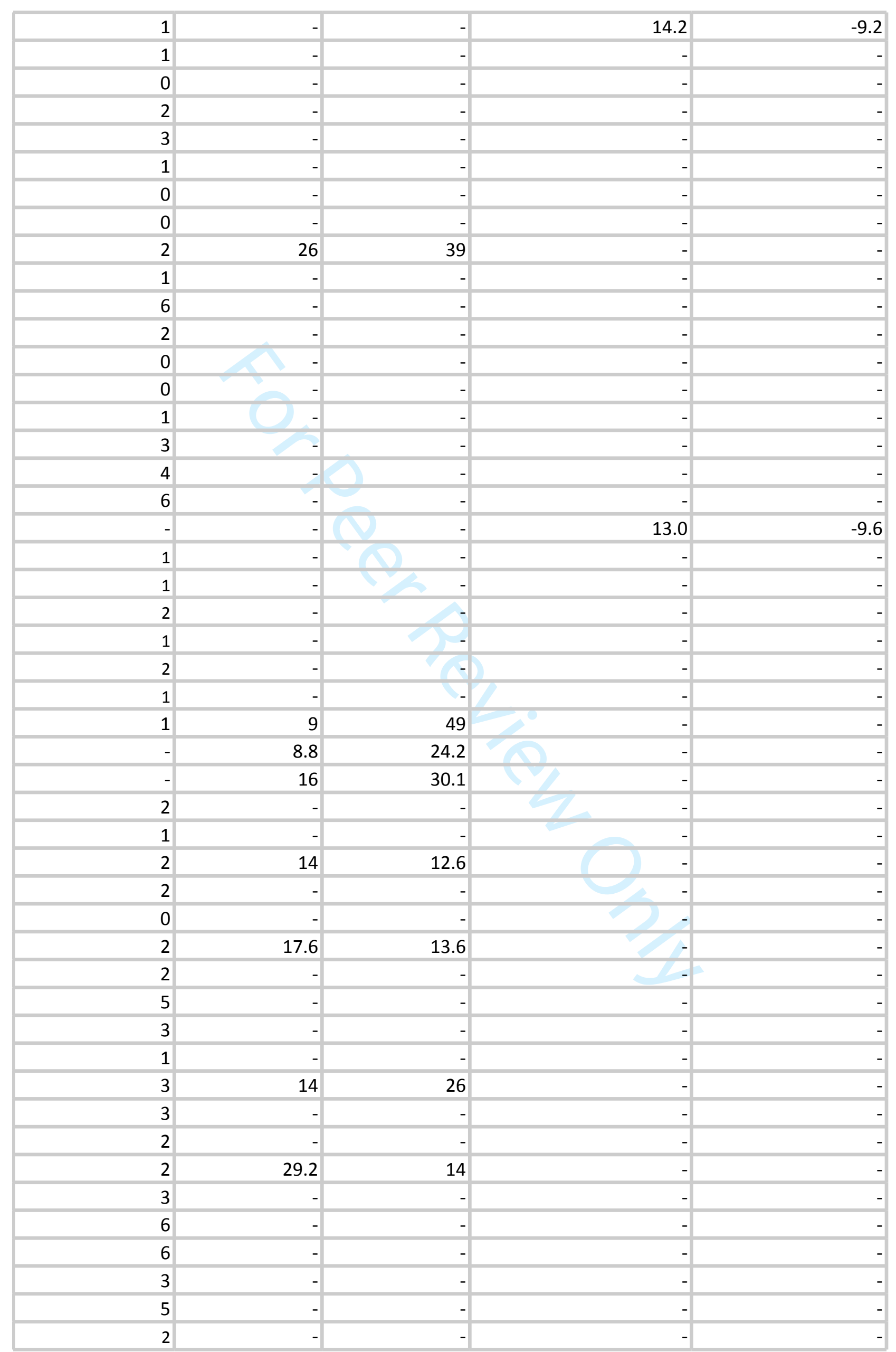

URL: http://mc.manuscriptcentral.com/ghbi 


\begin{tabular}{|c|c|c|c|c|}
\hline 5 & - & - & - & . \\
\hline 2 & 23.6 & 31 & - & . \\
\hline 5 & - & - & - & . \\
\hline 5 & - & - & - & . \\
\hline 5 & - & - & - & . \\
\hline 6 & - & - & - & . \\
\hline 5 & - & - & - & 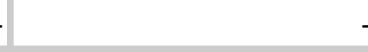 \\
\hline 2 & - & - & - & . \\
\hline 3 & - & - & - & . \\
\hline 4 & - & - & - & - \\
\hline 0 & - & - & - & . \\
\hline 0 & - & - & - & . \\
\hline 5 & - & - & - & . \\
\hline 5 & - & - & - & . \\
\hline 6 & - & - & - & 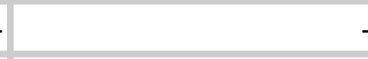 \\
\hline 0 & - & - & - & . \\
\hline 2 & 9 & 27 & - & . \\
\hline 0 & - & - & - & . \\
\hline 1 & - & $(N)$ & - & . \\
\hline 0 & - & $(N)$ & - & . \\
\hline 3 & - & 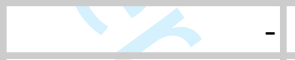 & - & . \\
\hline 3 & 24 & 19.2 & 14.4 & NA \\
\hline 6 & - & - & - & . \\
\hline 1 & 25.4 & 17.6 & - & . \\
\hline 1 & - & - & 8 & . \\
\hline 4 & - & - & 20 & . \\
\hline 5 & - & - & 0 & . \\
\hline 4 & - & - & $1>$ & . \\
\hline 5 & - & - & $+2=$ & . \\
\hline 5 & - & - & $\begin{array}{rr}13.0 \\
\end{array}$ & -6.8 \\
\hline 2 & - & - & 17.4 & -4.3 \\
\hline 4 & 23.8 & 8.2 & 15.1 & NA \\
\hline 3 & - & - & 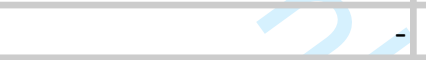 & . \\
\hline 1 & - & - & - & 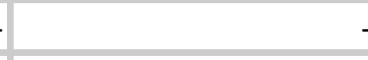 \\
\hline 5 & - & - & - & P \\
\hline 3 & - & - & - & . \\
\hline 1 & - & - & - & 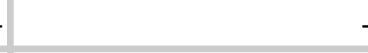 \\
\hline 2 & 19.6 & 43.6 & - & 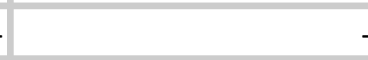 \\
\hline 2 & - & - & - & 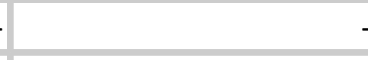 \\
\hline 2 & - & - & - & 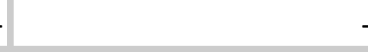 \\
\hline 2 & - & - & - & . \\
\hline 4 & - & - & - & 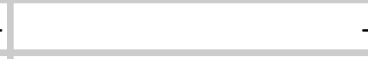 \\
\hline 3 & - & - & - & 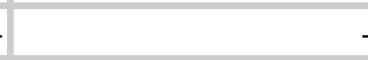 \\
\hline 6 & - & - & - & . \\
\hline 6 & - & - & - & 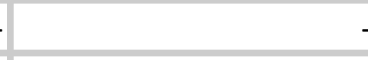 \\
\hline 1 & & - & - & . \\
\hline 2 & 23.6 & 19.2 & - & 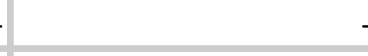 \\
\hline 2 & - & - & 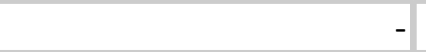 & 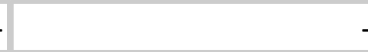 \\
\hline
\end{tabular}

URL: http://mc.manuscriptcentral.com/ghbi 


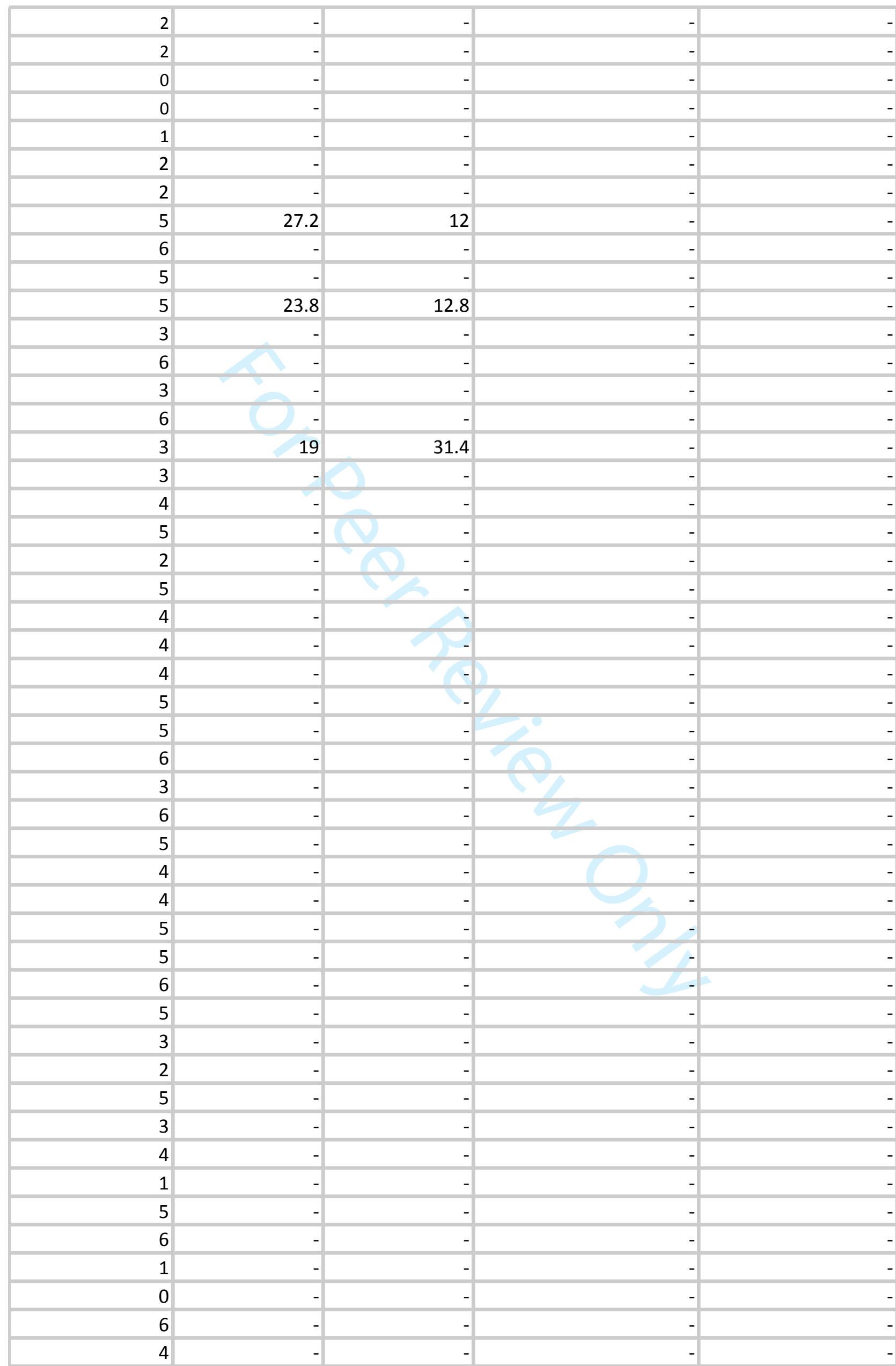




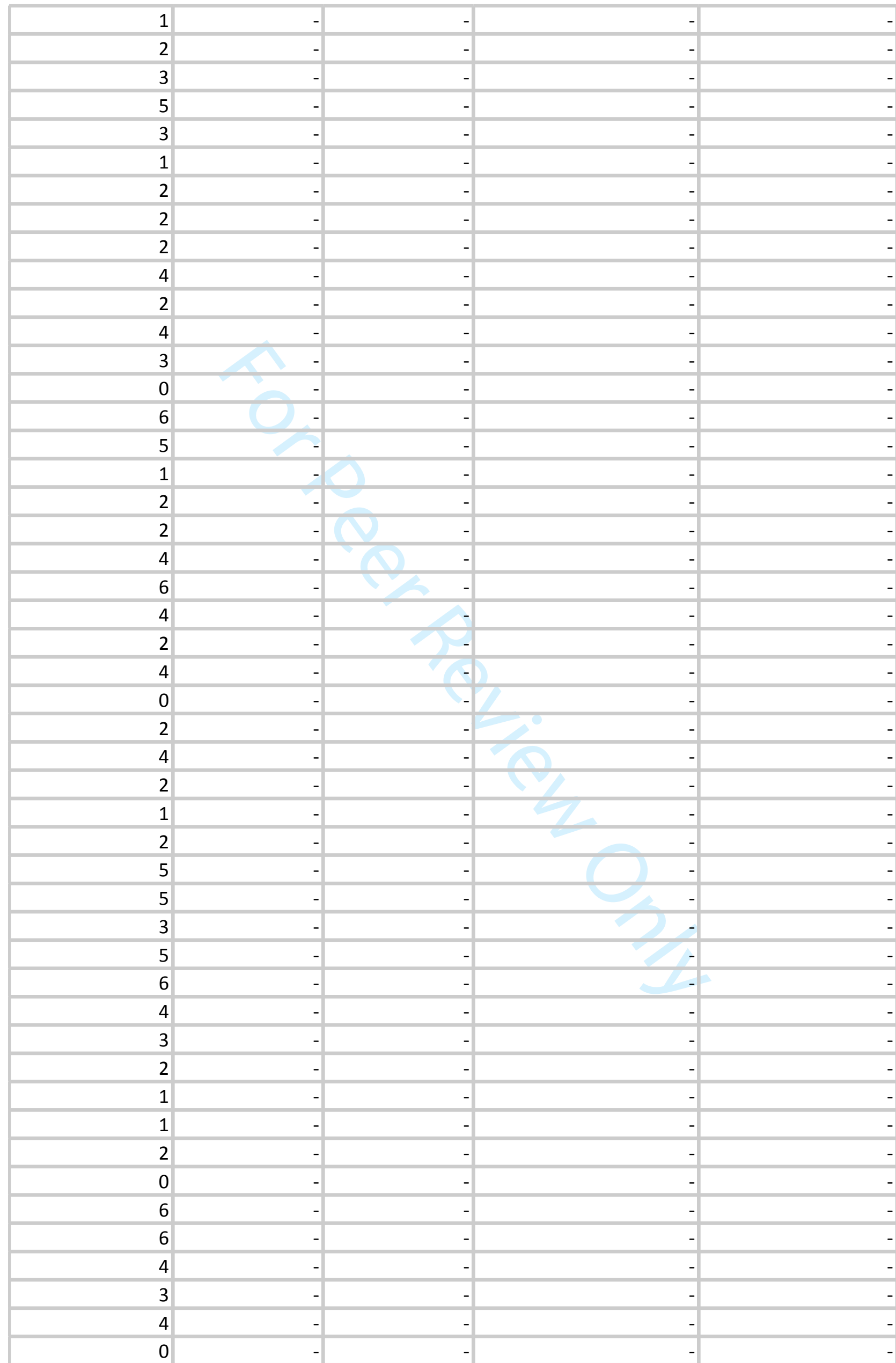

URL: http://mc.manuscriptcentral.com/ghbi 


\begin{tabular}{|c|c|c|c|c|}
\hline 4 & - & - & - & - \\
\hline 4 & - & - & - & - \\
\hline 2 & - & - & - & - \\
\hline 2 & - & - & - & - \\
\hline 4 & - & - & - & - \\
\hline 1 & - & - & - & - \\
\hline 5 & - & - & - & - \\
\hline 4 & - & - & - & - \\
\hline 2 & - & - & - & - \\
\hline 2 & - & - & - & - \\
\hline 0 & - & - & - & - \\
\hline 0 & - & - & - & - \\
\hline 0 & 8 & - & - & - \\
\hline 1 & - & - & - & - \\
\hline 2 & - & - & - & - \\
\hline 2 & - & - & - & - \\
\hline 2 & - & R) & - & - \\
\hline 6 & - & - & - & - \\
\hline 6 & - & $(1)$ & - & - \\
\hline 2 & 27.2 & $\begin{array}{r}12.4 \\
\end{array}$ & - & - \\
\hline 2 & 26.8 & $\begin{array}{r}14 \\
\end{array}$ & - & - \\
\hline 3 & - & $-1-2$ & - & - \\
\hline- & - & -1 & 13.7 & -9.0 \\
\hline- & 15.2 & 8.8 & - & - \\
\hline- & 18 & 8 & 8 & -9.7 \\
\hline- & 17 & 7 & 20 & - \\
\hline- & 15 & 9 & 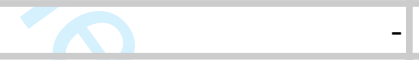 & - \\
\hline- & 13.2 & 7.4 & +8 & NA \\
\hline- & 15 & 6.6 & $x^{2}$ & -7.9 \\
\hline- & 16.6 & 9.2 & 2 & - \\
\hline- & 16.4 & 8.2 & - & - \\
\hline- & 18 & 8 & $e_{2}$ & - \\
\hline- & 13 & 16 & 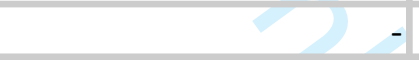 & - \\
\hline 2 & 14.8 & 23.8 & NA & -10.3 \\
\hline 6 & - & - & - & - \\
\hline 6 & - & - & - & - \\
\hline 0 & - & - & - & - \\
\hline 5 & - & - & - & - \\
\hline 6 & - & - & - & - \\
\hline 1 & - & - & - & - \\
\hline 3 & 23 & 9.5 & - & - \\
\hline 3 & 25 & 8 & 12.1 & NA \\
\hline 4 & - & - & - & - \\
\hline 6 & - & - & - & - \\
\hline 2 & - & - & - & - \\
\hline 6 & - & - & - & - \\
\hline 2 & - & - & - & - \\
\hline 5 & - & - & - & - \\
\hline
\end{tabular}




\begin{tabular}{|c|c|c|c|c|}
\hline 3 & - & - & - & - \\
\hline 5 & - & - & - & - \\
\hline 2 & 17.2 & 18 & 14.8 & NA \\
\hline- & - & - & NA & -4.8 \\
\hline 2 & 19.4 & 14.2 & - & - \\
\hline 3 & 18 & 13.2 & - & - \\
\hline 6 & - & - & - & - \\
\hline 5 & - & - & - & - \\
\hline 4 & - & - & - & - \\
\hline 4 & 24.8 & 12.4 & - & - \\
\hline- & 20.8 & 11.4 & - & - \\
\hline 2 & 17.8 & 7.4 & - & - \\
\hline 6 & - & - & - & - \\
\hline 6 & 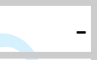 & - & - & - \\
\hline 6 & 20.4 & 11.2 & - & - \\
\hline 1 & 20.2 & 11.2 & - & - \\
\hline 5 & - & - & - & - \\
\hline 1 & - & - & - & - \\
\hline 5 & - & - & - & - \\
\hline 4 & 20.4 & 13.2 & - & - \\
\hline 5 & - & - & - & - \\
\hline 6 & - & - & - & - \\
\hline 3 & - & - & - & - \\
\hline 3 & - & - & - & - \\
\hline 6 & - & - & 18 & - \\
\hline 2 & - & - & 2 & - \\
\hline 2 & 11.2 & 6 & 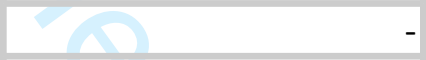 & - \\
\hline 2 & 13.6 & 8 & $+P$ & - \\
\hline 2 & 18 & 7.4 & $1=$ & - \\
\hline 4 & - & - & - & - \\
\hline 5 & - & - & - & - \\
\hline 6 & - & - & $\begin{array}{l}3=0 \\
-\end{array}$ & - \\
\hline 5 & 45.7 & 12 & - & 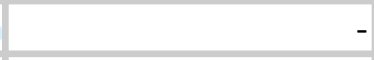 \\
\hline 4 & 27.3 & 31.2 & - & - \\
\hline- & 25 & 26.3 & - & - \\
\hline 3 & 28.6 & 20.1 & - & - \\
\hline 5 & 21 & 14 & 14.1 & -7.5 \\
\hline 1 & - & - & 15.9 & -6.5 \\
\hline- & 26 & 15.4 & 13.4 & NA \\
\hline 1 & - & - & 13.2 & -8.4 \\
\hline 2 & 26.8 & 7.4 & - & - \\
\hline- & - & - & 14.2 & NA \\
\hline- & - & - & 14.8 & -9.3 \\
\hline 5 & 24.2 & 43.2 & 11.1 & NA \\
\hline 6 & 25.2 & 42.6 & 12.4 & NA \\
\hline 6 & - & - & - & - \\
\hline 6 & - & - & - & - \\
\hline 5 & - & - & - & - \\
\hline
\end{tabular}

URL: http://mc.manuscriptcentral.com/ghbi 


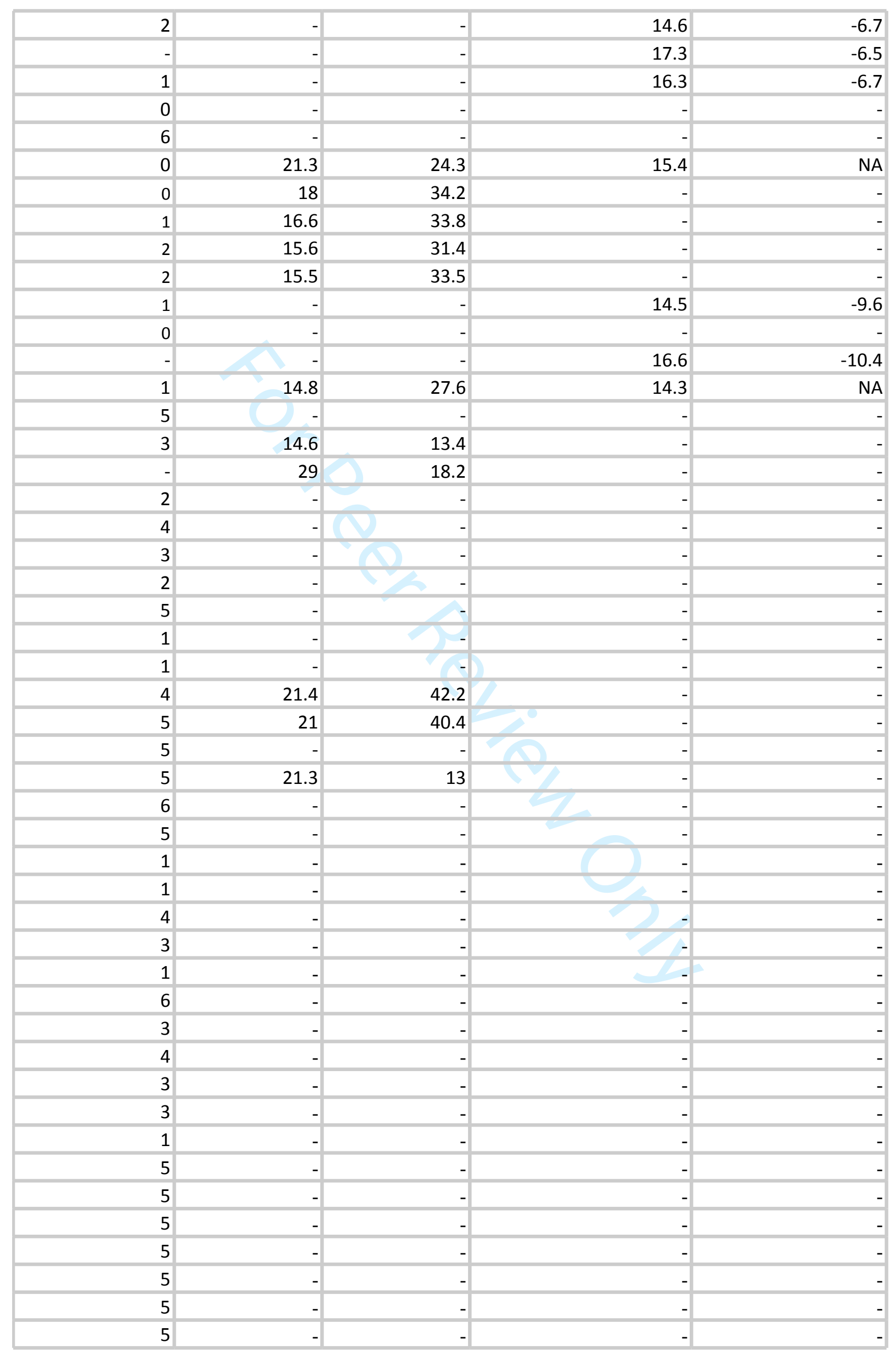




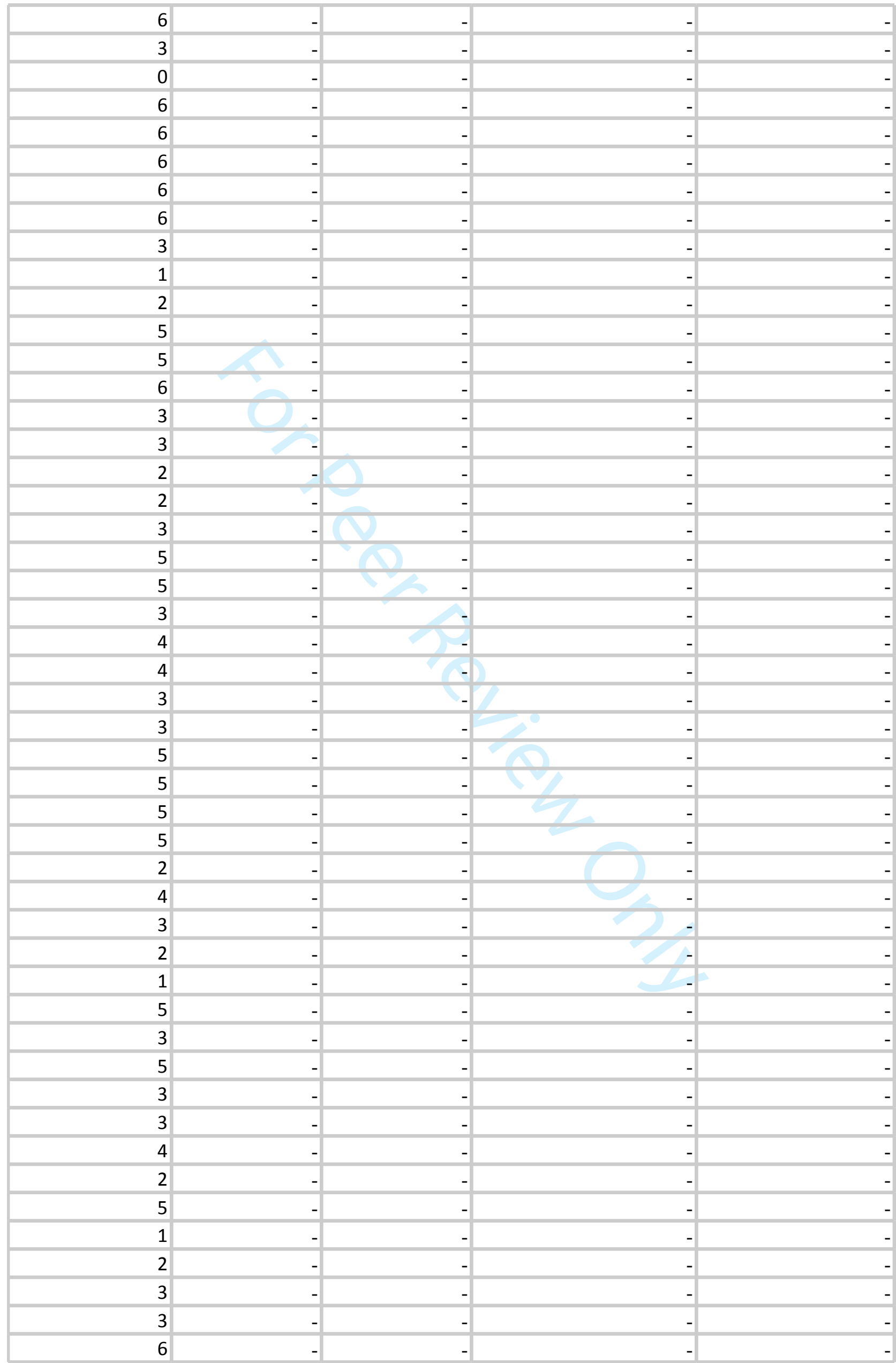

URL: http://mc.manuscriptcentral.com/ghbi 


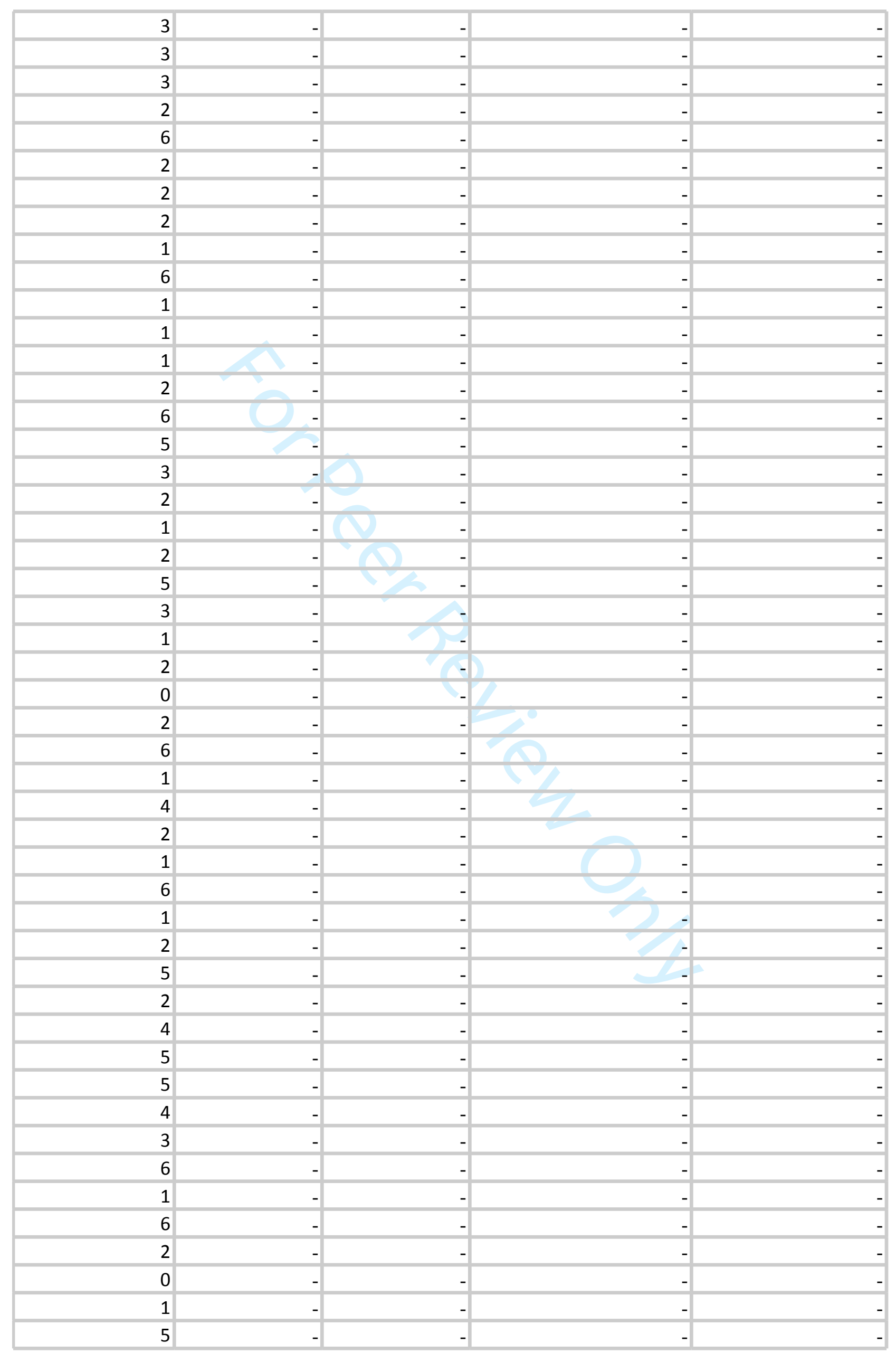

URL: http://mc.manuscriptcentral.com/ghbi 


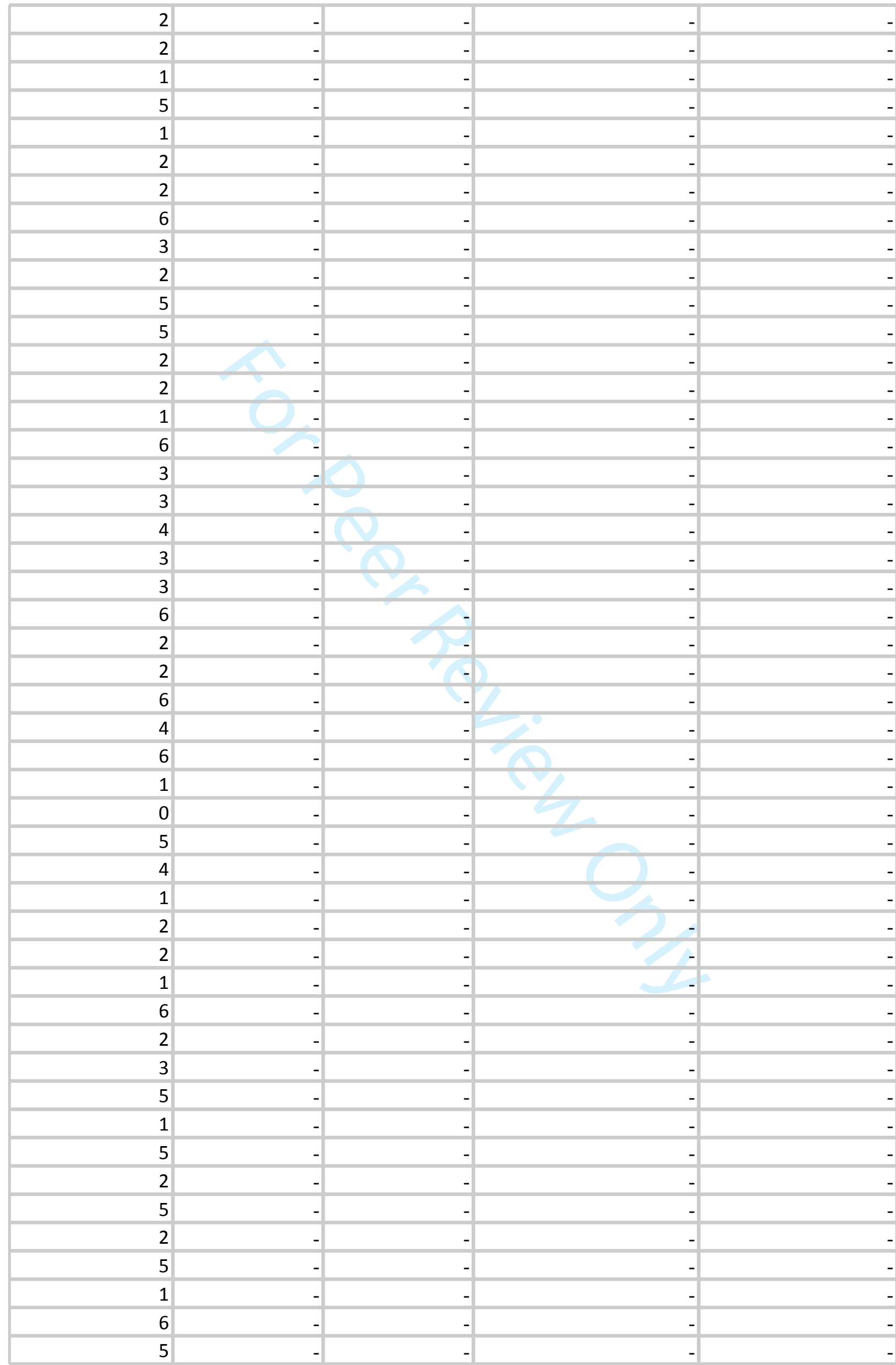

URL: http://mc.manuscriptcentral.com/ghbi 


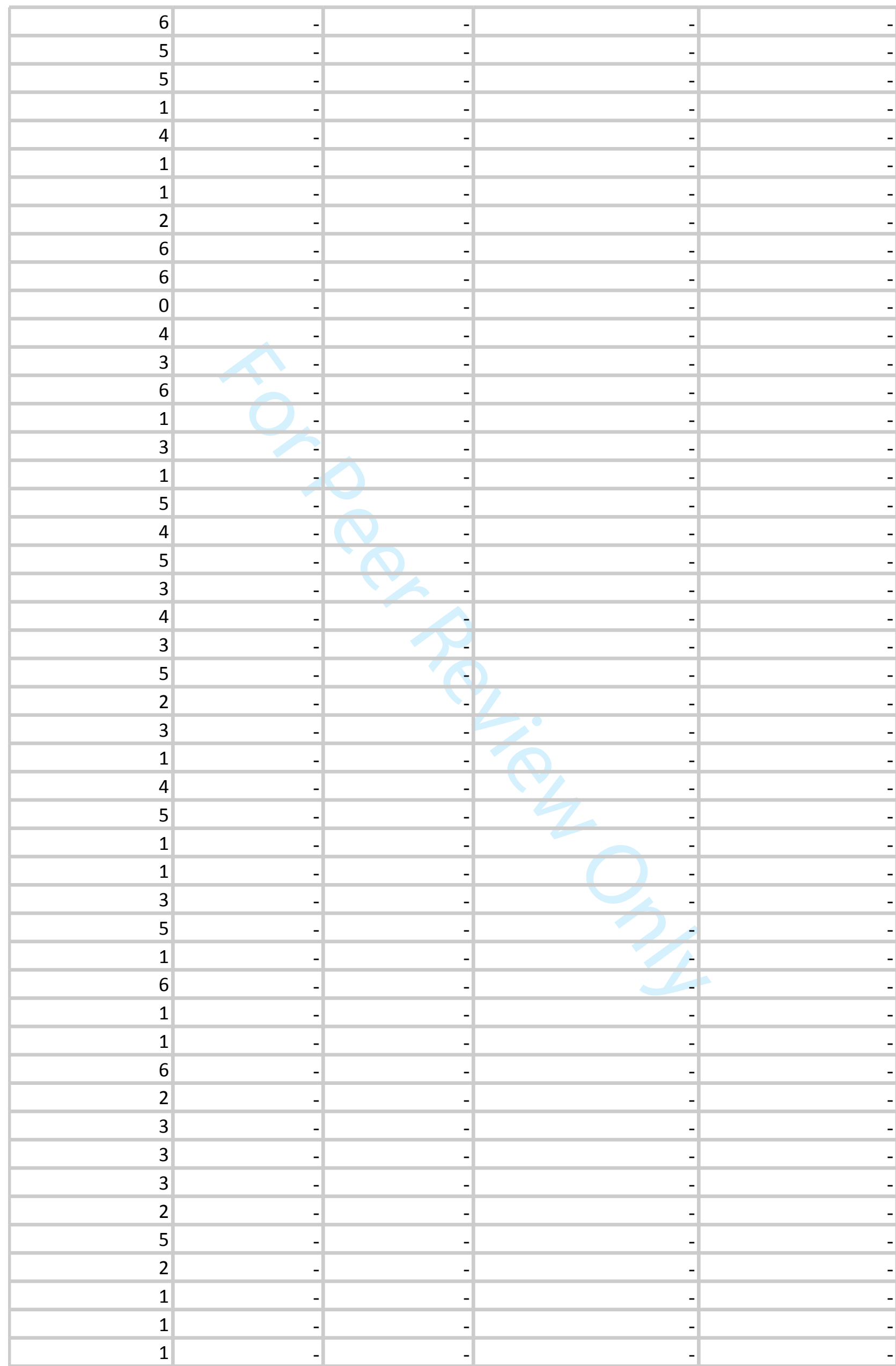

URL: http://mc.manuscriptcentral.com/ghbi 


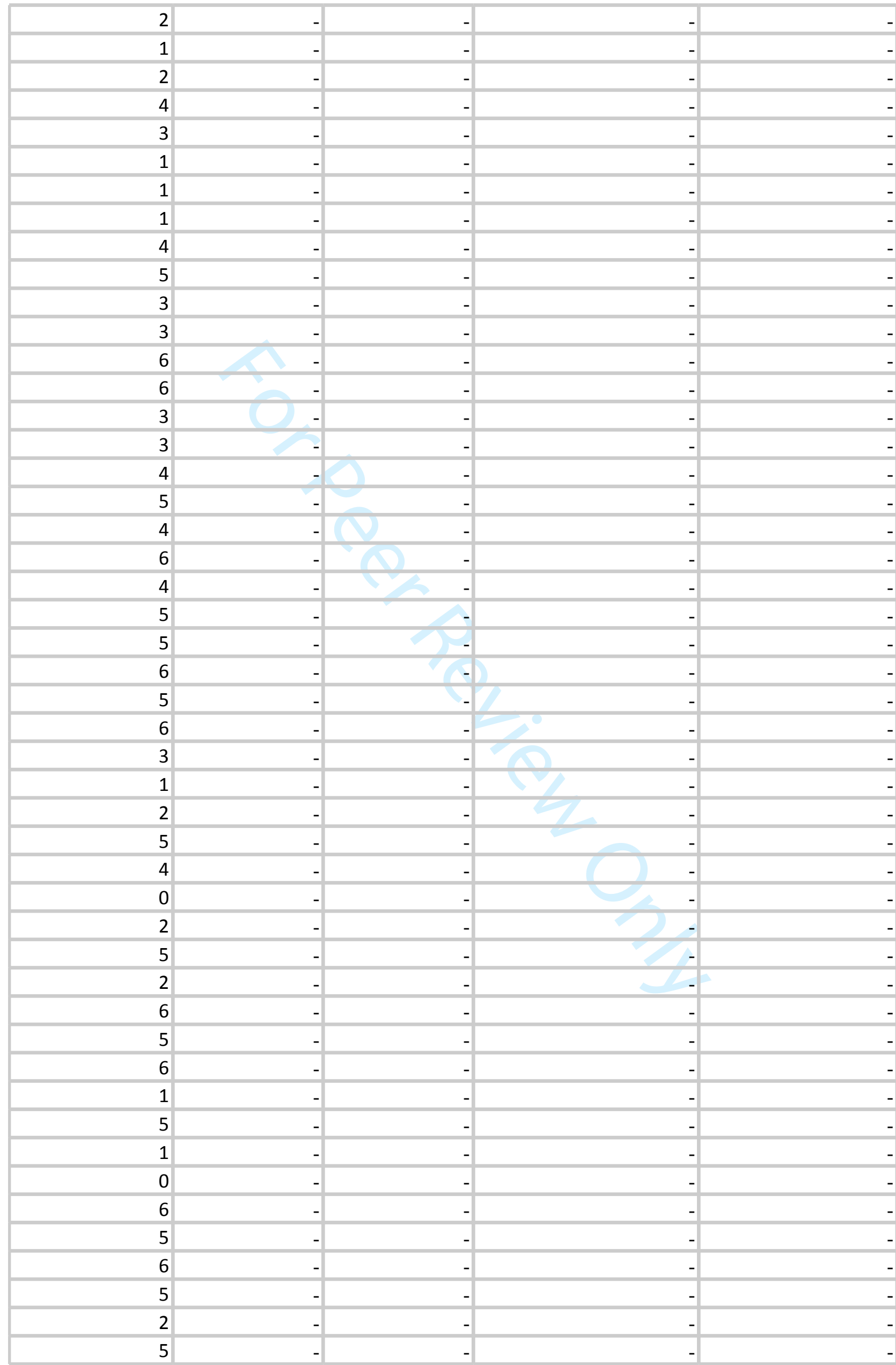

URL: http://mc.manuscriptcentral.com/ghbi 


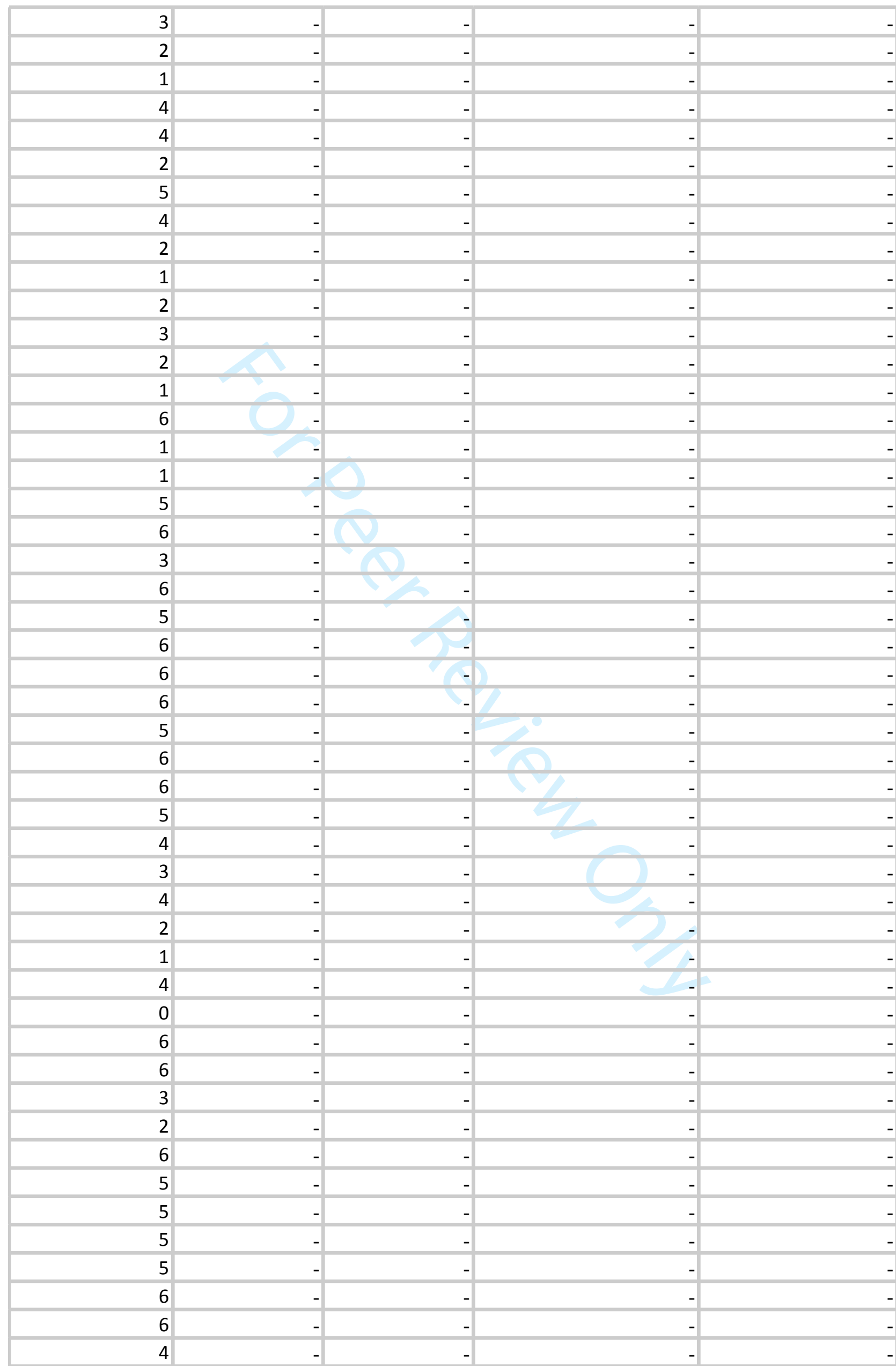

URL: http://mc.manuscriptcentral.com/ghbi 


\begin{tabular}{|c|c|c|c|}
\hline 4 & - & - & - \\
\hline 2 & - & - & - \\
\hline 1 & - & - & - \\
\hline 3 & - & - & - \\
\hline 5 & - & - & - \\
\hline 6 & - & - & - \\
\hline 6 & - & - & - \\
\hline 6 & - & - & - \\
\hline 5 & - & - & - \\
\hline 5 & - & - & - \\
\hline 3 & - & - & - \\
\hline 4 & - & - & - \\
\hline 4 & - & - & - \\
\hline 3 & - & - & - \\
\hline 5 & - & - & - \\
\hline 5 & - & - & - \\
\hline 4 & - & - & - \\
\hline 0 & - & - & - \\
\hline 5 & - & - & - \\
\hline 5 & - & - & - \\
\hline 5 & - & - & - \\
\hline 6 & - & - & - \\
\hline 6 & - & - & - \\
\hline 4 & - & - & - \\
\hline 3 & - & _ & - \\
\hline
\end{tabular}




\begin{tabular}{|c|c|}
\hline 8180CO3 [\%o] VSMOW & $813 \mathrm{CCO} 3 \%$ [\%] VPDB \\
\hline & \\
\hline & \\
\hline & \\
\hline & \\
\hline & \\
\hline & \\
\hline & \\
\hline & \\
\hline & \\
\hline & 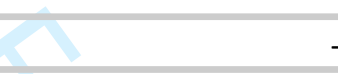 \\
\hline & 2 \\
\hline & J) \\
\hline & 8 \\
\hline & \\
\hline & \\
\hline & (N) \\
\hline & $(0)-$ \\
\hline $\begin{array}{l}- \\
-\end{array}$ & 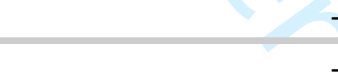 \\
\hline & \\
\hline & \\
\hline & \\
\hline & \\
\hline & \\
\hline & \\
\hline- & \\
\hline & \\
\hline 22.9 & -10.5 \\
\hline NA & NA \\
\hline & \\
\hline - & \\
\hline & \\
\hline & \\
\hline & \\
\hline & \\
\hline & \\
\hline - & \\
\hline- & \\
\hline- & \\
\hline - & \\
\hline & \\
\hline & \\
\hline & \\
\hline
\end{tabular}




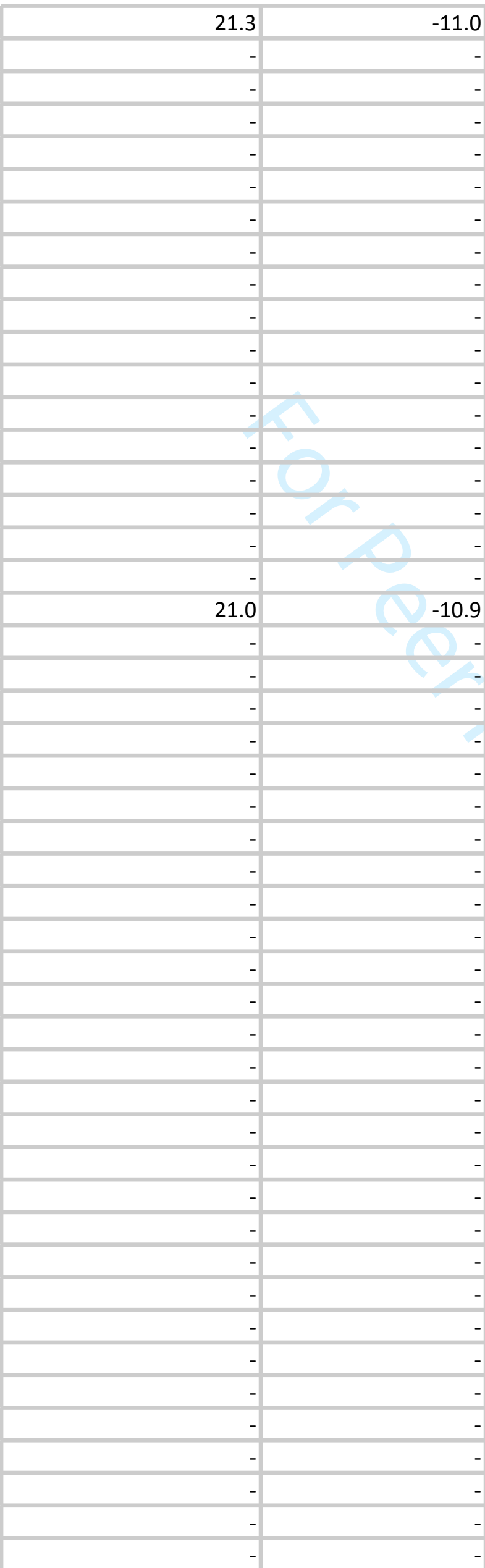

URL: http://mc.manuscriptcentral.com/ghbi 


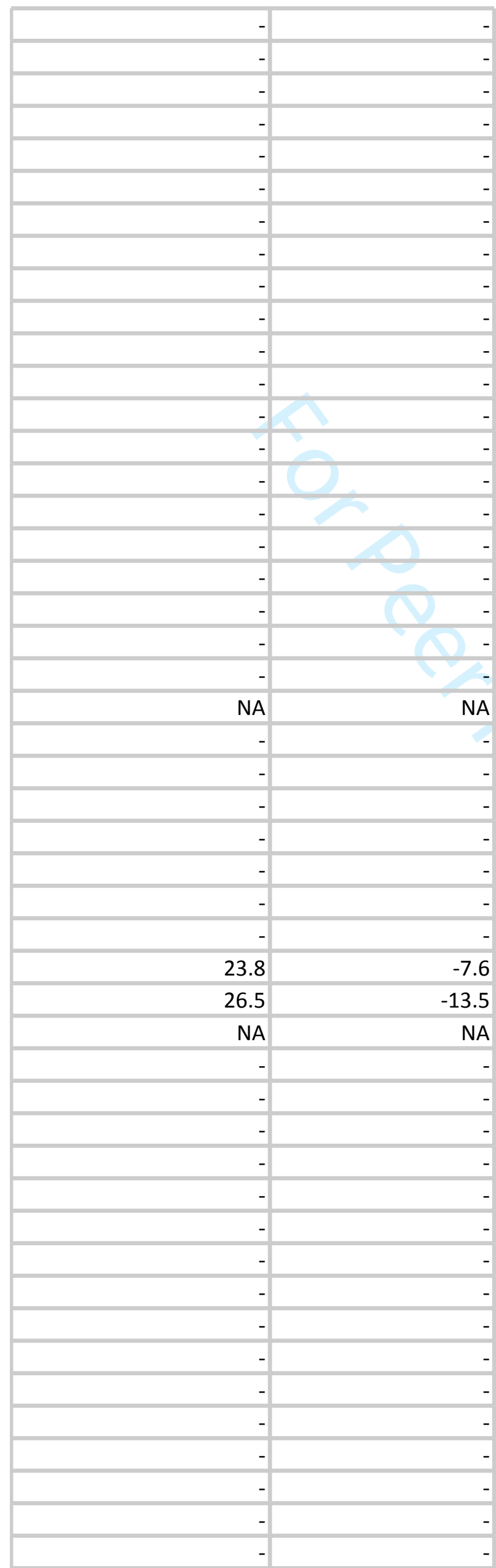

URL: http://mc.manuscriptcentral.com/ghbi 


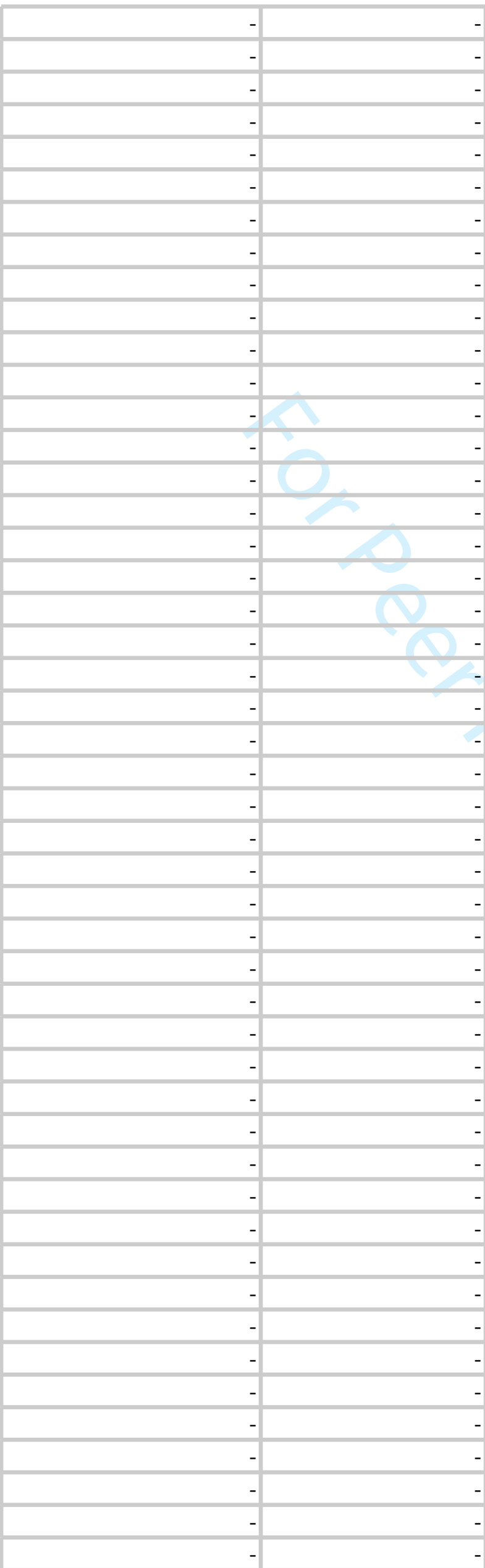

URL: http://mc.manuscriptcentral.com/ghbi 


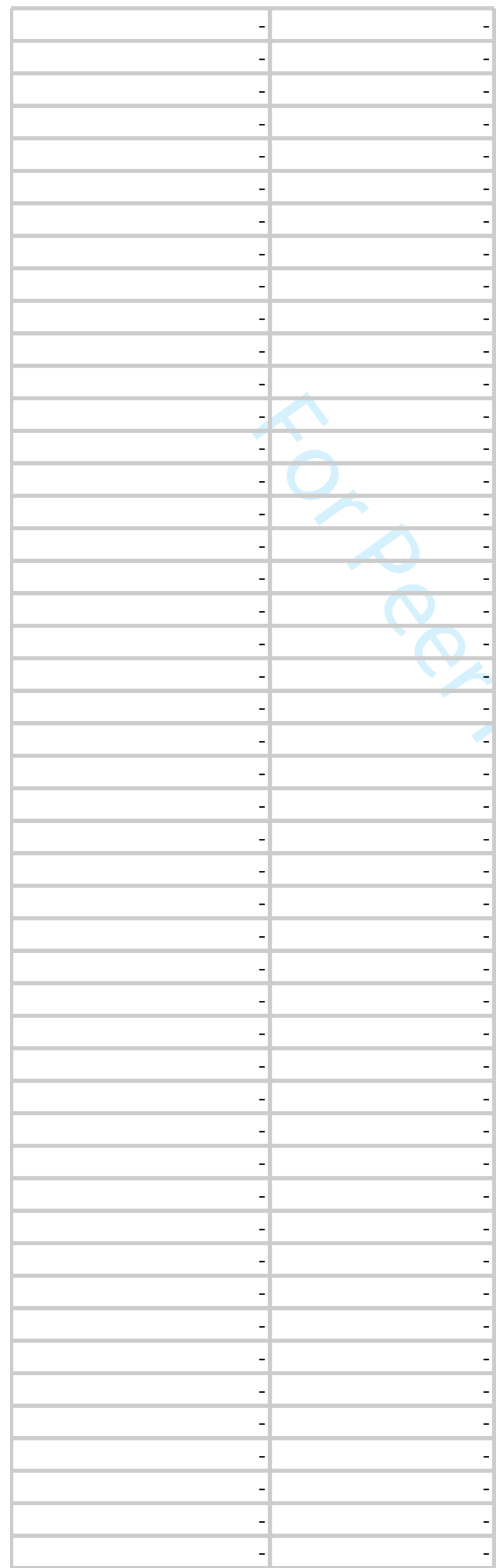

URL: http://mc.manuscriptcentral.com/ghbi 


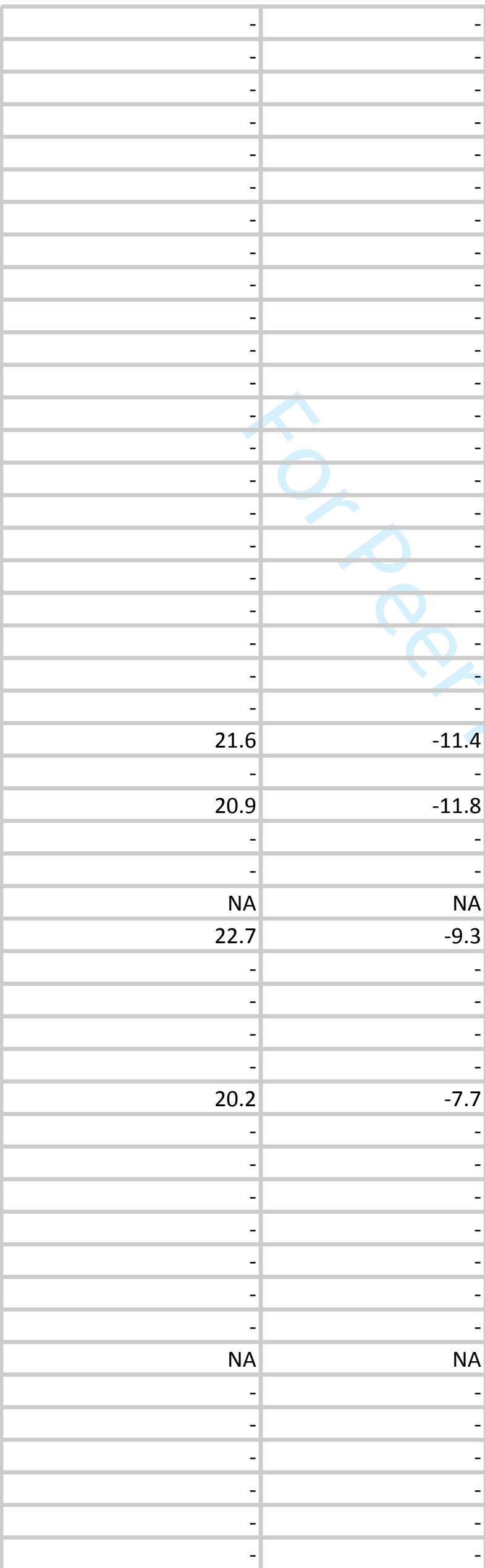

URL: http://mc.manuscriptcentral.com/ghbi 


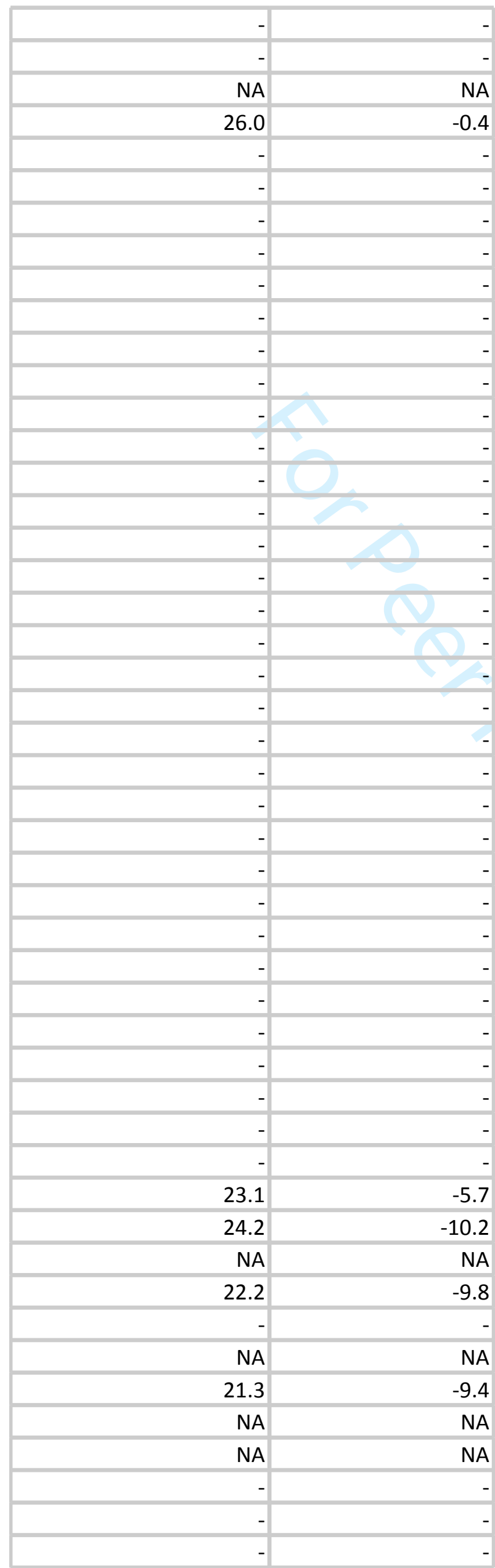




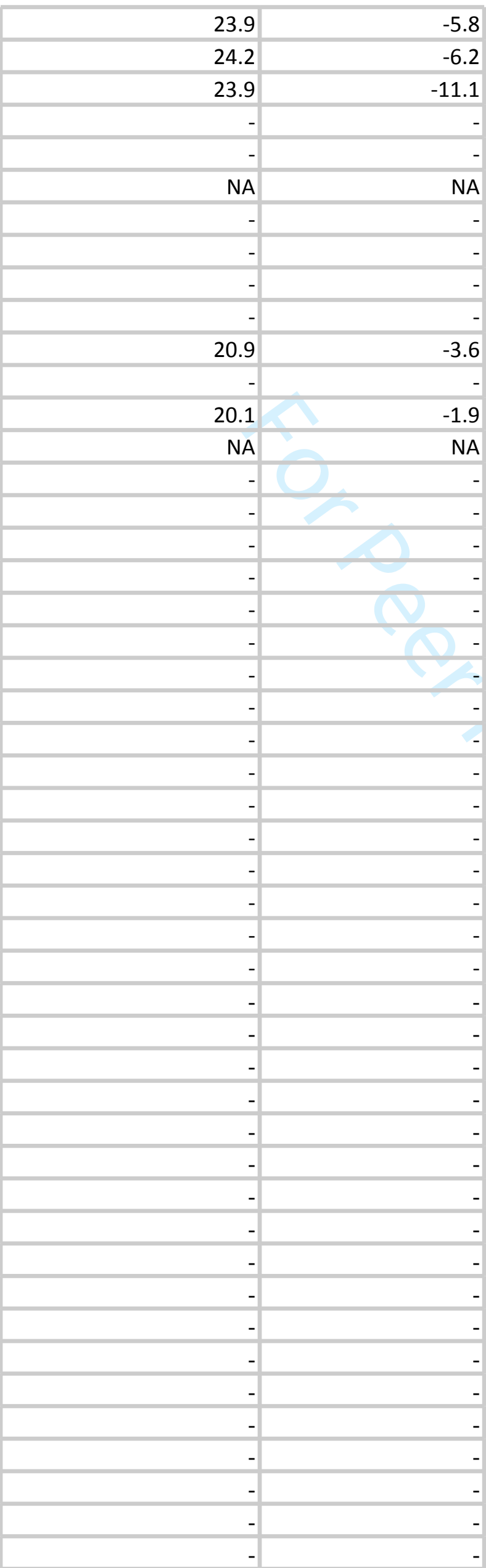

URL: http://mc.manuscriptcentral.com/ghbi 


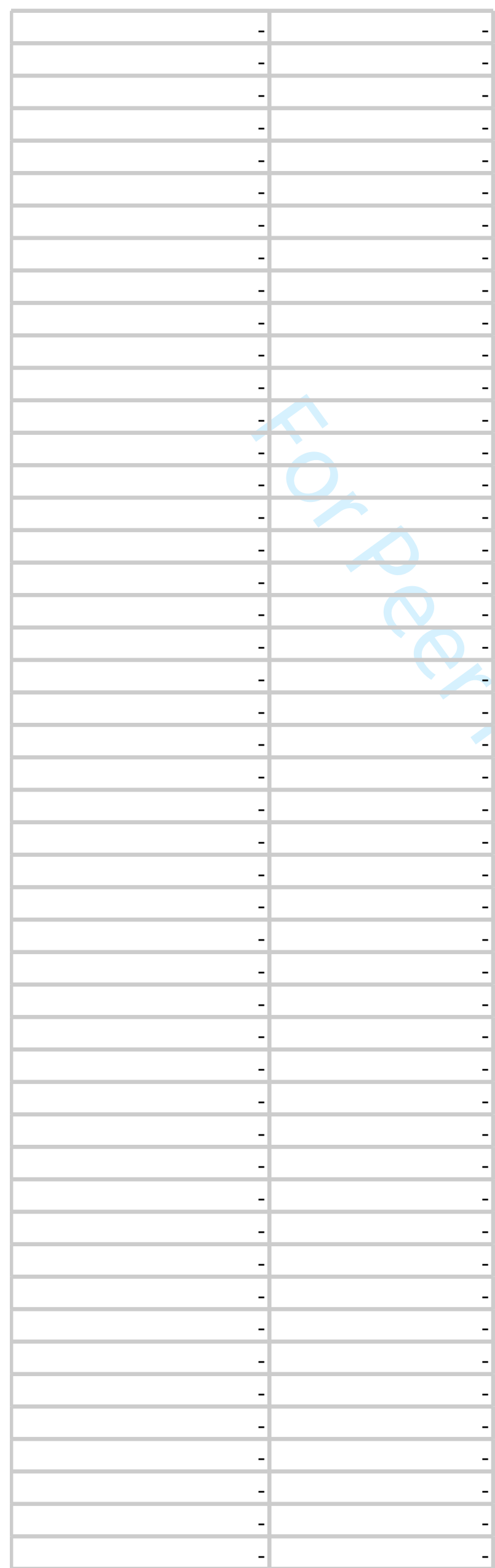

URL: http://mc.manuscriptcentral.com/ghbi 


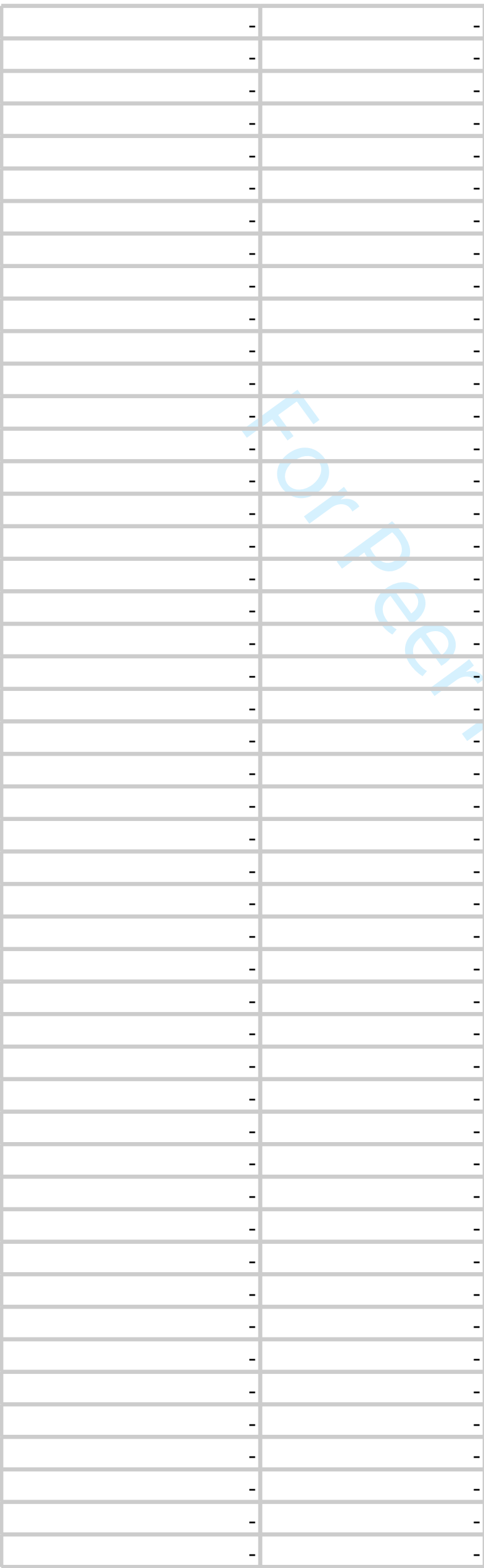

URL: http://mc.manuscriptcentral.com/ghbi 


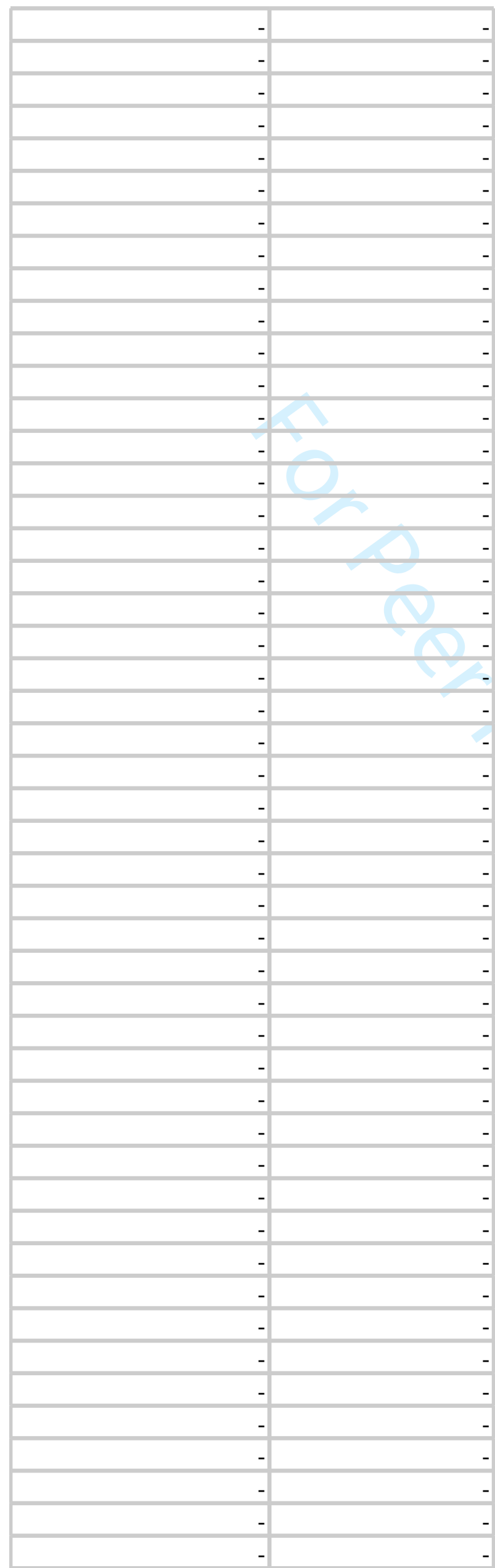

URL: http://mc.manuscriptcentral.com/ghbi 


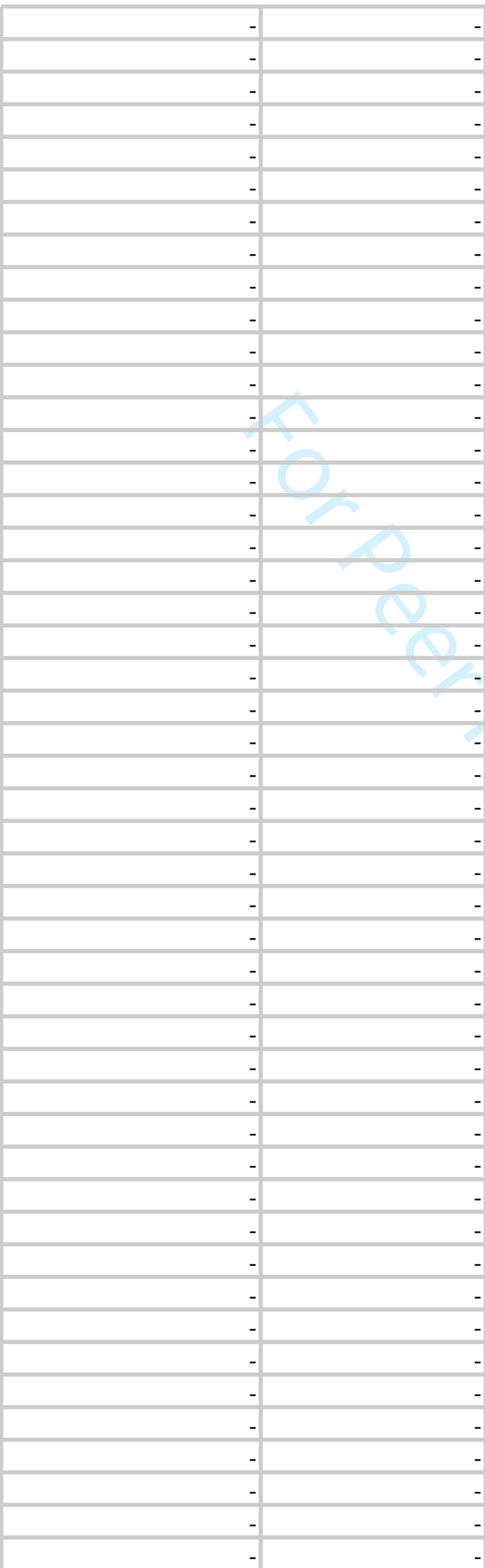

URL: http://mc.manuscriptcentral.com/ghbi 


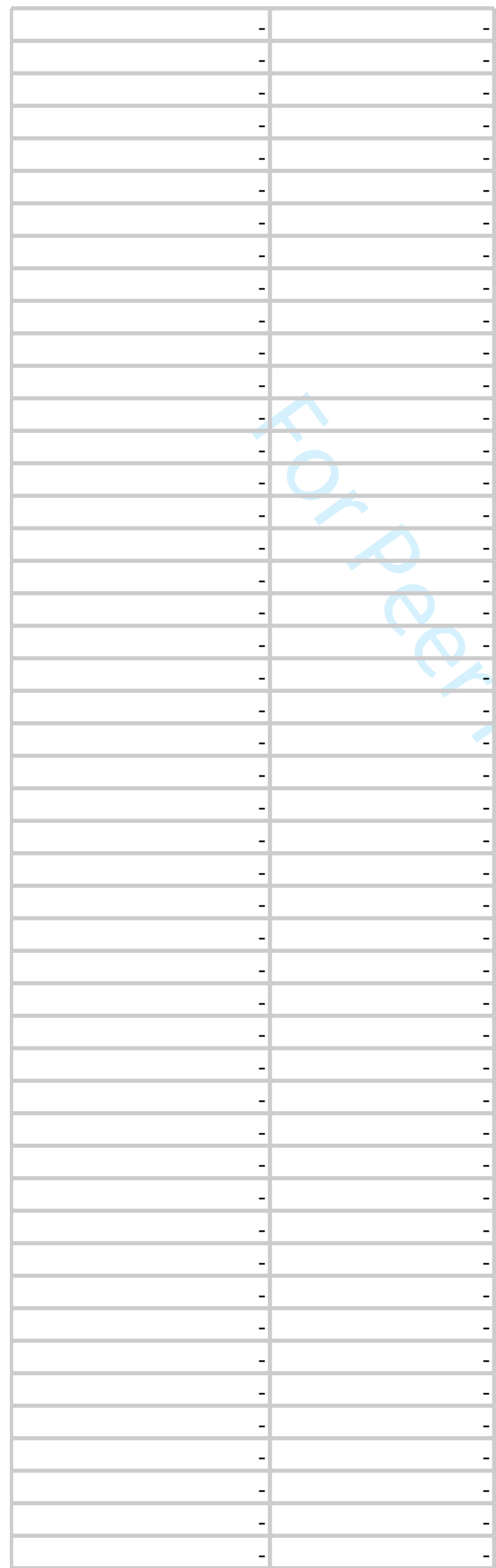

URL: http://mc.manuscriptcentral.com/ghbi 


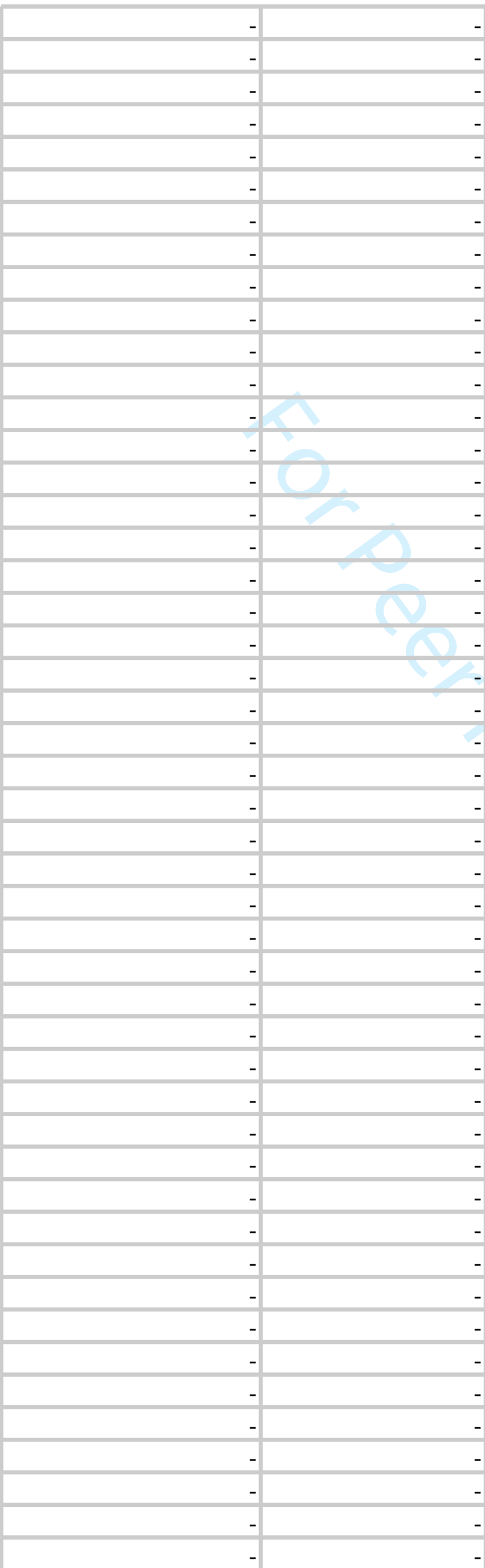

URL: http://mc.manuscriptcentral.com/ghbi 


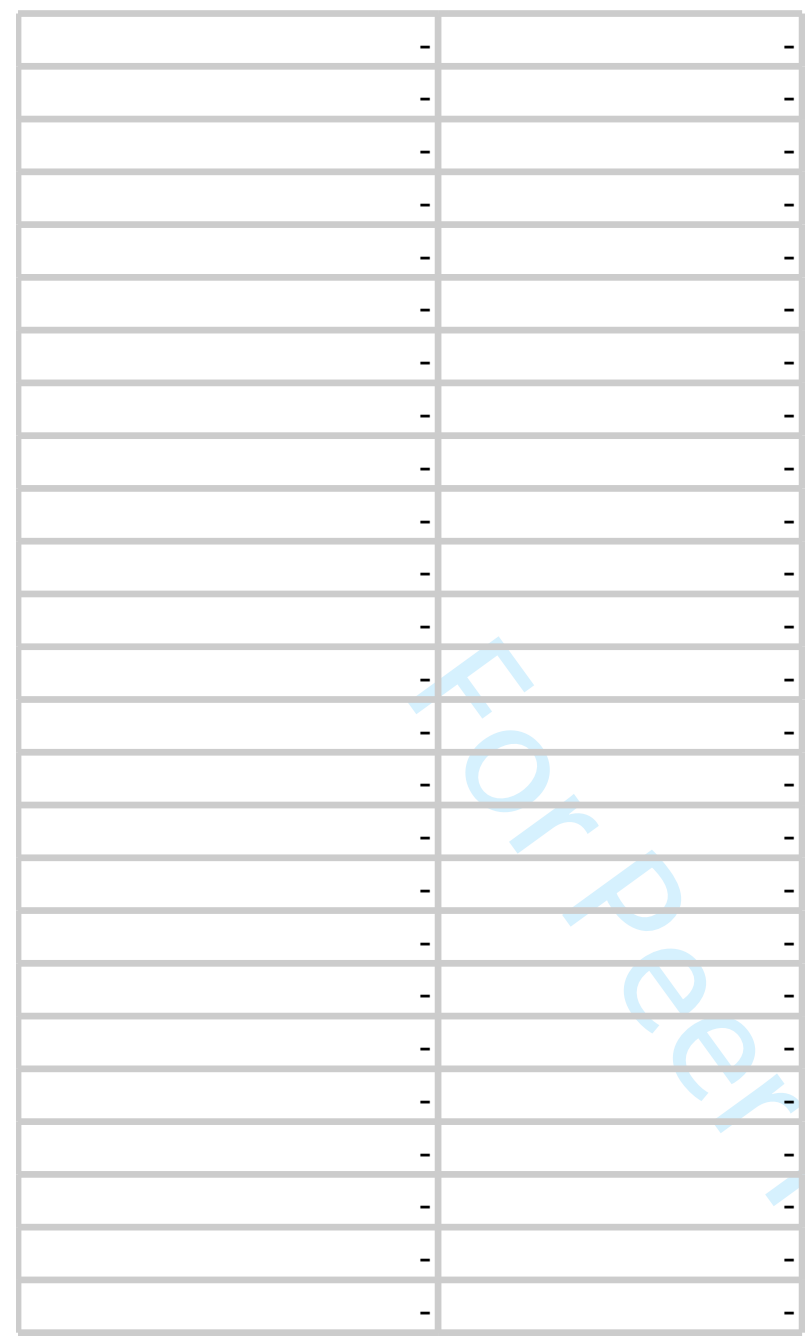




\begin{tabular}{|c|c|c|c|c|c|c|}
\hline Country & Latitude & Longitude & Altitude & 018 & \multicolumn{2}{|c|}{ Precipitatio Air Temper } \\
\hline VIENNA (HC AT & 48.24861 & 16.35639 & 198 & -18.2 & 40 & -6 \\
\hline VIENNA (HCAT & 48.24861 & 16.35639 & 198 & -16.31 & 40 & -5.3 \\
\hline VIENNA (HCAT & 48.24861 & 16.35639 & 198 & -11.4 & 7 & -4.7 \\
\hline VIENNA (HCAT & 48.24861 & 16.35639 & 198 & -18.19 & 44 & -4.7 \\
\hline VIENNA (HCAT & 48.24861 & 16.35639 & 198 & -21.6 & 22 & -4.5 \\
\hline VIENNA (HCAT & 48.24861 & 16.35639 & 198 & -18.18 & 82 & -4.4 \\
\hline VIENNA (HCAT & 48.24861 & 16.35639 & 198 & -12.2 & 13 & -4.3 \\
\hline VIENNA (HC AT & 48.24861 & 16.35639 & 198 & -24.41 & 64 & -3.5 \\
\hline VIENNA (HCAT & 48.24861 & 16.35639 & 198 & -14.04 & 21 & -3.4 \\
\hline VIENNA (HCAT & 48.24861 & 16.35639 & 198 & -18.7 & 34 & -3.3 \\
\hline VIENNA (HCAT & 48.24861 & 16.35639 & 198 & -16.23 & 48 & -3.3 \\
\hline VIENNA (HCAT & 48.24861 & 16.35639 & 198 & -15.6 & 42 & -3.2 \\
\hline VIENNA (HCAT & 48.24861 & 16.35639 & 198 & -19.18 & 40 & -3.2 \\
\hline VIENNA (HCAT & 48.24861 & 16.35639 & 198 & -14.02 & 25 & -3.1 \\
\hline VIENNA (HC AT & 48.24861 & 16.35639 & 198 & -15 & 57 & -3.1 \\
\hline VIENNA (HC AT & 48.24861 & 16.35639 & 198 & -18.7 & 48 & -2.7 \\
\hline VIENNA (HCAT & 48.24861 & 16.35639 & 198 & -12.54 & 38 & -2.6 \\
\hline VIENNA (HCAT & 48.24861 & 16.35639 & 198 & -11.47 & 25 & -2.4 \\
\hline VIENNA (HC AT & 48.24861 & 16.35639 & 198 & -12.46 & 14 & -2.4 \\
\hline VIENNA (HC AT & 48.24861 & 16.35639 & 198 & -17.6 & 24 & -2.3 \\
\hline VIENNA (HCAT & 48.24861 & 16.35639 & 198 & -18.9099 & 42 & -2.3 \\
\hline VIENNA (HC AT & 48.24861 & 16.35639 & 198 & -18.14 & 12 & -2.1 \\
\hline VIENNA (HC AT & 48.24861 & 16.35639 & 198 & -11.8 & 27 & -2.1 \\
\hline VIENNA (HCAT & 48.24861 & 16.35639 & 198 & -15.1 & 47 & -2 \\
\hline VIENNA (HCAT & 48.24861 & 16.35639 & 198 & -17.35 & 31 & -2 \\
\hline VIENNA (HC AT & 48.24861 & 16.35639 & 198 & -17.53 & 17 & -2 \\
\hline VIENNA (HCAT & 48.24861 & 16.35639 & 198 & -12.8073 & 56 & -1.9 \\
\hline VIENNA (HCAT & 48.24861 & 16.35639 & 198 & -13.56 & 17 & -1.8 \\
\hline VIENNA (HC AT & 48.24861 & 16.35639 & 198 & -13.24 & 54 & -1.6 \\
\hline VIENNA (HCAT & 48.24861 & 16.35639 & 198 & -15.56 & 50 & -1.5 \\
\hline VIENNA (HCAT & 48.24861 & 16.35639 & 198 & -13.99 & 35 & -1.5 \\
\hline VIENNA (HCAT & 48.24861 & 16.35639 & 198 & -14.68 & 71 & -1.4 \\
\hline VIENNA (HCAT & 48.24861 & 16.35639 & 198 & -11.6 & 52 & -1.1 \\
\hline VIENNA (HCAT & 48.24861 & 16.35639 & 198 & -15.36 & 14 & -1.1 \\
\hline VIENNA ( $\mathrm{HC}$ AT & 48.24861 & 16.35639 & 198 & -13.11 & 64 & -1 \\
\hline VIENNA (HCAT & 48.24861 & 16.35639 & 198 & -19.54 & 39 & -1 \\
\hline VIENNA (HC AT & 48.24861 & 16.35639 & 198 & -16.44 & 48 & -0.9 \\
\hline VIENNA (HCAT & 48.24861 & 16.35639 & 198 & -19.34 & 77 & -0.9 \\
\hline VIENNA (HCAT & 48.24861 & 16.35639 & 198 & -12.69 & 23 & -0.8 \\
\hline VIENNA (HC AT & 48.24861 & 16.35639 & 198 & -11.19 & 34 & -0.7 \\
\hline VIENNA (HCAT & 48.24861 & 16.35639 & 198 & -14.78 & 26 & -0.7 \\
\hline VIENNA (HCAT & 48.24861 & 16.35639 & 198 & -18.51 & 30 & -0.6 \\
\hline VIENNA (HC AT & 48.24861 & 16.35639 & 198 & -13.37 & 49 & -0.6 \\
\hline VIENNA (HC AT & 48.24861 & 16.35639 & 198 & -12.85 & 46 & -0.6 \\
\hline VIENNA (HC AT & 48.24861 & 16.35639 & 198 & -14.65 & 35 & -0.6 \\
\hline VIENNA (HCAT & 48.24861 & 16.35639 & 198 & -14.26 & 55 & -0.5 \\
\hline VIENNA (HC AT & 48.24861 & 16.35639 & 198 & -14.4 & 49 & -0.4 \\
\hline VIENNA (HCAT & 48.24861 & 16.35639 & 198 & -12.75 & 66 & -0.4 \\
\hline JNA ( HCAT & 48.24861 & 16.35639 & 198 & -10.65 & 64 & -0 \\
\hline
\end{tabular}




\begin{tabular}{|c|c|c|c|c|c|c|}
\hline VIENNA (HC AT & 48.24861 & 16.35639 & 198 & -20.74 & 79 & -0.3 \\
\hline VIENNA (HC AT & 48.24861 & 16.35639 & 198 & -13.65 & 36 & -0.2 \\
\hline VIENNA (HCAT & 48.24861 & 16.35639 & 198 & -18.16 & 70 & -0.2 \\
\hline VIENNA (HCAT & 48.24861 & 16.35639 & 198 & -16.23 & 47 & -0.1 \\
\hline VIENNA (HC AT & 48.24861 & 16.35639 & 198 & -10.23 & 25 & 0.2 \\
\hline VIENNA (HC AT & 48.24861 & 16.35639 & 198 & -13.99 & 27 & 0.2 \\
\hline VIENNA (HC AT & 48.24861 & 16.35639 & 198 & -12.98 & 109 & 0.4 \\
\hline VIENNA (HC AT & 48.24861 & 16.35639 & 198 & -12.6 & 59 & 0.4 \\
\hline VIENNA (HCAT & 48.24861 & 16.35639 & 198 & -15.46 & 39 & 0.4 \\
\hline VIENNA (HCAT & 48.24861 & 16.35639 & 198 & -12.99 & 19 & 0.5 \\
\hline VIENNA (HCAT & 48.24861 & 16.35639 & 198 & -16.93 & 86 & 0.5 \\
\hline VIENNA (HC AT & 48.24861 & 16.35639 & 198 & -9.7 & 29 & 0.6 \\
\hline VIENNA (HCAT & 48.24861 & 16.35639 & 198 & -13.67 & 21 & 0.6 \\
\hline VIENNA (HCAT & 48.24861 & 16.35639 & 198 & -13.88 & 57 & 0.6 \\
\hline VIENNA (HCAT & 48.24861 & 16.35639 & 198 & -17.68 & 35 & 0.6 \\
\hline VIENNA (HC AT & 48.24861 & 16.35639 & 198 & -11.11 & 74 & 0.6 \\
\hline VIENNA (HC AT & 48.24861 & 16.35639 & 198 & -14.92 & 52 & 0.6 \\
\hline VIENNA (HC AT & 48.24861 & 16.35639 & 198 & -11.95 & 105 & 0.6 \\
\hline VIENNA (H(AT & 48.24861 & 16.35639 & 198 & -14.75 & 57 & 0.7 \\
\hline VIENNA (HC AT & 48.24861 & 16.35639 & 198 & -13.875 & 17 & 0.7 \\
\hline VIENNA (HC AT & 48.24861 & 16.35639 & 198 & -13.29 & 60 & 0.7 \\
\hline VIENNA (HC AT & 48.24861 & 16.35639 & 198 & -6.35687 & 10 & 0.7 \\
\hline VIENNA (HC AT & 48.24861 & 16.35639 & 198 & -15.2 & 42 & 0.8 \\
\hline VIENNA (HC AT & 48.24861 & 16.35639 & 198 & -18.41 & 35 & 0.8 \\
\hline VIENNA (HC AT & 48.24861 & 16.35639 & 198 & -13.93 & 43 & 0.8 \\
\hline VIENNA (HC AT & 48.24861 & 16.35639 & 198 & -15.9245 & 20 & 0.8 \\
\hline VIENNA (HC AT & 48.24861 & 16.35639 & 198 & -13.63 & 52 & 0.8 \\
\hline VIENNA (HC AT & 48.24861 & 16.35639 & 198 & -9.67 & 43 & 0.8 \\
\hline VIENNA (HC AT & 48.24861 & 16.35639 & 198 & -16.4 & 39 & 0.9 \\
\hline VIENNA (HC AT & 48.24861 & 16.35639 & 198 & -14.45 & 26 & 0.9 \\
\hline VIENNA (HC AT & 48.24861 & 16.35639 & 198 & -8.945 & 8 & 1 \\
\hline VIENNA (HC AT & 48.24861 & 16.35639 & 198 & -15.39 & 29 & 1.1 \\
\hline VIENNA (HCAT & 48.24861 & 16.35639 & 198 & -8.16 & 20 & 1.1 \\
\hline VIENNA (HC AT & 48.24861 & 16.35639 & 198 & -8.98 & 5 & 1.1 \\
\hline VIENNA (HCAT & 48.24861 & 16.35639 & 198 & -12.935 & 113 & 1.1 \\
\hline VIENNA (HC AT & 48.24861 & 16.35639 & 198 & -11.97 & 36 & 1.1 \\
\hline VIENNA (HCAT & 48.24861 & 16.35639 & 198 & -12.42 & 55 & 1.2 \\
\hline VIENNA (HC AT & 48.24861 & 16.35639 & 198 & -12.74 & 72 & 1.2 \\
\hline VIENNA (HC AT & 48.24861 & 16.35639 & 198 & -12.0195 & 31.5 & 1.2 \\
\hline VIENNA (HC AT & 48.24861 & 16.35639 & 198 & -17.2 & 72 & 1.3 \\
\hline VIENNA (HCAT & 48.24861 & 16.35639 & 198 & -15.07 & 25 & 1.3 \\
\hline VIENNA (HC AT & 48.24861 & 16.35639 & 198 & -11.84 & 15 & 1.3 \\
\hline VIENNA (HC AT & 48.24861 & 16.35639 & 198 & -16.66 & 56 & 1.3 \\
\hline VIENNA (HC AT & 48.24861 & 16.35639 & 198 & -16.18 & 37 & 1.4 \\
\hline VIENNA (HCAT & 48.24861 & 16.35639 & 198 & -13.27 & 19 & 1.4 \\
\hline VIENNA (HC AT & 48.24861 & 16.35639 & 198 & -13.91 & 16 & 1.4 \\
\hline VIENNA (HC AT & 48.24861 & 16.35639 & 198 & -9.52 & 52 & 1.4 \\
\hline VIENNA (HC AT & 48.24861 & 16.35639 & 198 & -7.74 & 29 & 1.4 \\
\hline VIENNA (HCAT & 48.24861 & 16.35639 & 198 & -13.52 & 61 & \\
\hline VIENNA (HCAT & 48.24861 & 16.35639 & 198 & -13.32 & 37 & \\
\hline
\end{tabular}




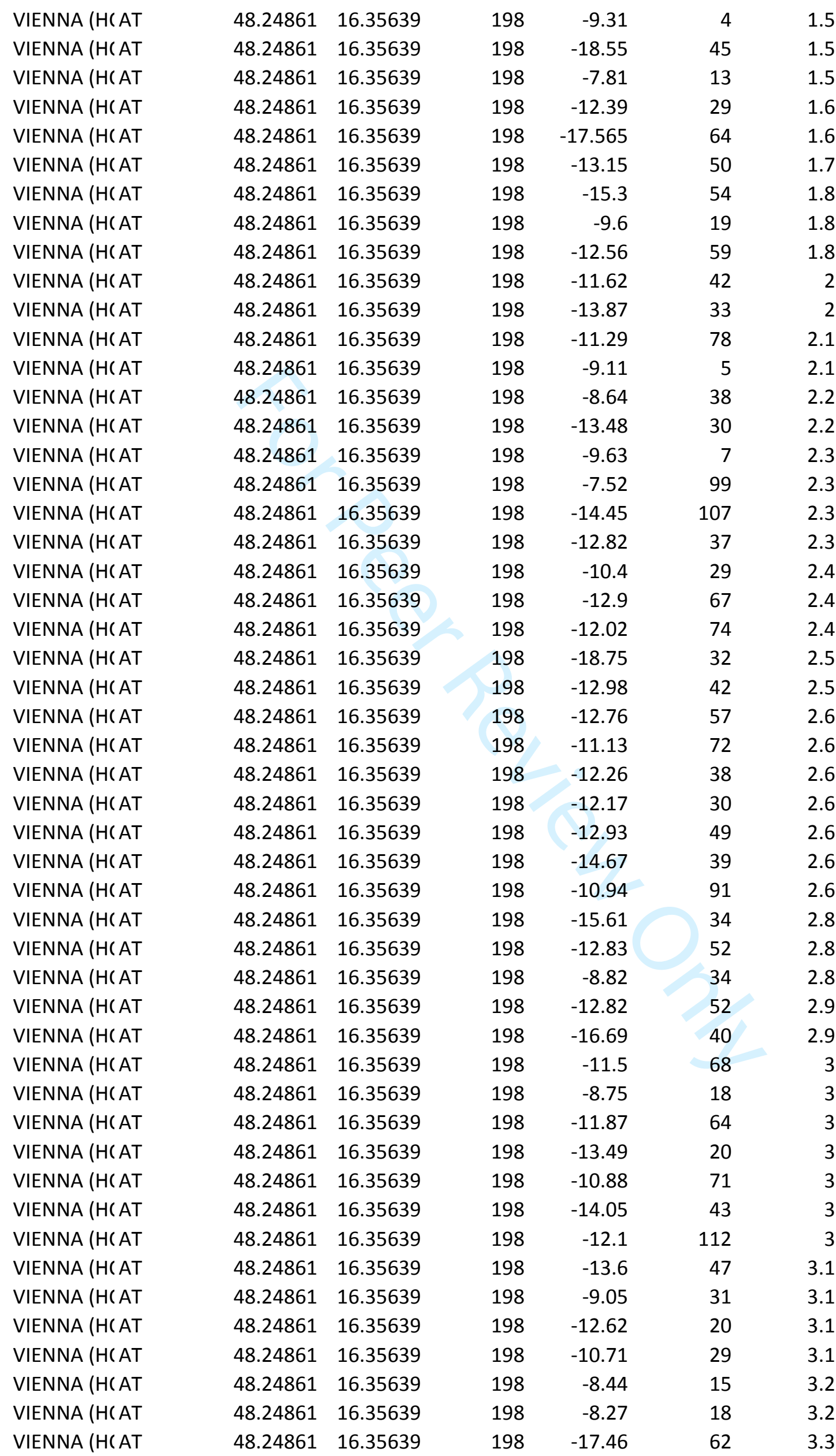




\begin{tabular}{|c|c|c|c|c|c|c|}
\hline VIENNA (HC AT & 48.24861 & 16.35639 & 198 & -10.05 & 89 & 3.3 \\
\hline VIENNA (HC AT & 48.24861 & 16.35639 & 198 & -9.31 & 9 & 3.4 \\
\hline VIENNA (HCAT & 48.24861 & 16.35639 & 198 & -16.19 & 75 & 34 \\
\hline VIENNA (HCAT & 48.24861 & 16.35639 & 198 & -13.57 & 79 & 3.4 \\
\hline VIENNA (HC AT & 48.24861 & 16.35639 & 198 & -6.22 & 8 & 4 \\
\hline VIENNA (HC AT & 48.24861 & 16.35639 & 198 & -13.07 & 30 & 3.5 \\
\hline VIENNA (HCAT & 48.24861 & 16.35639 & 198 & -14.655 & 52 & 3.5 \\
\hline VIENNA (HC AT & 48.24861 & 16.35639 & 198 & -9 & 17 & 3.5 \\
\hline VIENNA (HCAT & 48.24861 & 16.35639 & 198 & -12.11 & 50 & 3.5 \\
\hline VIENNA (HC AT & 48.24861 & 16.35639 & 198 & -14.65 & 45 & 3.7 \\
\hline VIENNA (HC AT & 48.24861 & 16.35639 & 198 & -12.11 & 66 & 3.7 \\
\hline VIENNA (HC AT & 48.24861 & 16.35639 & 198 & -11.69 & 68 & 3.7 \\
\hline VIENNA (HCAT & 48.24861 & 16.35639 & 198 & -9.75 & 24 & 3.7 \\
\hline VIENNA (HC AT & 48.24861 & 16.35639 & 198 & -13.3 & 84 & 3.8 \\
\hline VIENNA (HC AT & 48.24861 & 16.35639 & 198 & -12.05 & 33 & 3.8 \\
\hline VIENNA (HC AT & 48.24861 & 16.35639 & 198 & -6.9 & 22 & 3.8 \\
\hline VIENNA (HCAT & 48.24861 & 16.35639 & 198 & -10.04 & 55 & 3.8 \\
\hline VIENNA (HC AT & 48.24861 & 16.35639 & 198 & -10.6185 & 18 & 3.8 \\
\hline VIENNA (HC AT & 48.24861 & 16.35639 & 198 & -9.9 & 68 & 3.9 \\
\hline VIENNA (HC AT & 48.24861 & 16.35639 & 198 & -14.5 & 101 & 3.9 \\
\hline VIENNA (HCAT & 48.24861 & 16.35639 & 198 & -15.1 & 49 & 3.9 \\
\hline VIENNA (HC AT & 48.24861 & 16.35639 & 198 & -11.01 & 43 & 3.9 \\
\hline VIENNA (HC AT & 48.24861 & 16.35639 & 198 & -12 & 43 & . \\
\hline VIENNA (HC AT & 48.24861 & 16.35639 & 198 & -14.18 & 60 & 4 \\
\hline VIENNA (HCAT & 48.24861 & 16.35639 & 198 & -11.64 & 19 & 4 \\
\hline VIENNA (HC AT & 48.24861 & 16.35639 & 198 & -11.29 & 56 & 4.1 \\
\hline VIENNA (HC AT & 48.24861 & 16.35639 & 198 & -14.55 & 21 & 4.1 \\
\hline VIENNA (HC AT & 48.24861 & 16.35639 & 198 & -8.75 & 25 & 4.1 \\
\hline VIENNA (HCAT & 48.24861 & 16.35639 & 198 & -11.45 & 39 & 4.2 \\
\hline VIENNA (HCAT & 48.24861 & 16.35639 & 198 & -13.84 & 45 & 4.2 \\
\hline VIENNA (HC AT & 48.24861 & 16.35639 & 198 & -13.16 & 64 & 4.2 \\
\hline VIENNA (HC AT & 48.24861 & 16.35639 & 198 & -14 & 25 & 4.2 \\
\hline VIENNA (HCAT & 48.24861 & 16.35639 & 198 & -10.55 & 46 & 4.2 \\
\hline VIENNA (HC AT & 48.24861 & 16.35639 & 198 & -12.81 & 44 & 4.3 \\
\hline VIENNA (HC AT & 48.24861 & 16.35639 & 198 & -7.3 & 61 & 4.4 \\
\hline VIENNA (HCAT & 48.24861 & 16.35639 & 198 & -11.44 & 31 & 4.4 \\
\hline VIENNA (HC AT & 48.24861 & 16.35639 & 198 & -7.34 & 10 & 4.4 \\
\hline VIENNA (HC AT & 48.24861 & 16.35639 & 198 & -11.6 & 44 & 4.5 \\
\hline VIENNA (HC AT & 48.24861 & 16.35639 & 198 & -13.01 & 92 & 4.5 \\
\hline VIENNA (H(AT & 48.24861 & 16.35639 & 198 & -12.43 & 22 & 4.7 \\
\hline VIENNA (HCAT & 48.24861 & 16.35639 & 198 & -9.11 & 17 & 4.7 \\
\hline VIENNA (HC AT & 48.24861 & 16.35639 & 198 & -13.75 & 47 & 4.7 \\
\hline VIENNA (HC AT & 48.24861 & 16.35639 & 198 & -10.01 & 45 & 4.8 \\
\hline VIENNA (HC AT & 48.24861 & 16.35639 & 198 & -12.37 & 66 & 4.8 \\
\hline VIENNA (HCAT & 48.24861 & 16.35639 & 198 & -12.08 & 58 & 4.9 \\
\hline VIENNA (HC AT & 48.24861 & 16.35639 & 198 & -15.93 & 64 & כ \\
\hline VIENNA (HC AT & 48.24861 & 16.35639 & 198 & -11.9 & 107 & 5 \\
\hline VIENNA (HC AT & 48.24861 & 16.35639 & 198 & -8.91 & 27 & 5 \\
\hline VIENNA (HC AT & 48.24861 & 16.35639 & 198 & -13.97 & 75 & 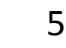 \\
\hline VIENNA (HCAT & 48.24861 & 16.35639 & 198 & -10.59 & 36 & \\
\hline
\end{tabular}




\begin{tabular}{|c|c|c|c|c|c|c|}
\hline VIENNA (HCAT & 48.24861 & 16.35639 & 198 & -11.51 & 94 & 5.1 \\
\hline VIENNA (HCAT & 48.24861 & 16.35639 & 198 & -11.23 & 58 & 5.2 \\
\hline VIENNA (HCAT & 48.24861 & 16.35639 & 198 & -13.8 & 72 & .2 \\
\hline VIENNA (HCAT & 48.24861 & 16.35639 & 198 & -10.1 & 22 & .3 \\
\hline VIENNA (HCAT & 48.24861 & 16.35639 & 198 & -9.41 & 47 & \\
\hline VIENNA (HCAT & 48.24861 & 16.35639 & 198 & -9.99 & 63 & .3 \\
\hline VIENNA (HCAT & 48.24861 & 16.35639 & 198 & -16.96 & 72 & .4 \\
\hline VIENNA (HCAT & 48.24861 & 16.35639 & 198 & -11.86 & 57 & .5 \\
\hline VIENNA (HCAT & 48.24861 & 16.35639 & 198 & -7.14 & 31 & 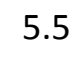 \\
\hline VIENNA (HCAT & 48.24861 & 16.35639 & 198 & -12.45 & 32 & 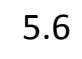 \\
\hline VIENNA (HCAT & 48.24861 & 16.35639 & 198 & -14.1 & 36 & \\
\hline VIENNA (HCAT & 48.24861 & 16.35639 & 198 & -12.25 & 34 & 5.7 \\
\hline VIENNA (HCAT & 48.24861 & 16.35639 & 198 & -12.81 & 145 & .7 \\
\hline VIENNA (HCAT & 48.24861 & 16.35639 & 198 & -13.17 & 69 & 5.8 \\
\hline VIENNA (HCAT & 48.24861 & 16.35639 & 198 & -7.84 & 91 & .8 \\
\hline VIENNA (HCAT & 48.24861 & 16.35639 & 198 & -14.4 & 112 & 59 \\
\hline VIENNA (HCAT & 48.24861 & 16.35639 & 198 & -5.98 & 54 & .9 \\
\hline VIENNA (HCAT & 48.24861 & 16.35639 & 198 & -13.2755 & 18 & \\
\hline VIENNA (HCAT & 48.24861 & 16.35639 & 198 & -11.91 & 96 & 5.1 \\
\hline VIENNA (HCAT & 48.24861 & 16.35639 & 198 & -2.69 & 4 & 5.1 \\
\hline VIENNA (HCAT & 48.24861 & 16.35639 & 198 & -6.78 & 37 & 5.2 \\
\hline VIENNA (HCAT & 48.24861 & 16.35639 & 198 & -14.77 & 48 & 2 \\
\hline VIENNA (HCAT & 48.24861 & 16.35639 & 198 & -14.66 & 41 & 6.2 \\
\hline VIENNA (HCAT & 48.24861 & 16.35639 & 198 & -10.68 & 22 & 6.3 \\
\hline VIENNA (HCAT & 48.24861 & 16.35639 & 198 & -8.94 & 81 & 6.3 \\
\hline VIENNA (HCAT & 48.24861 & 16.35639 & 198 & -11.11 & 48 & 6.4 \\
\hline VIENNA (HCAT & 48.24861 & 16.35639 & 198 & -9.32 & 21 & 5.4 \\
\hline VIENNA (HCAT & 48.24861 & 16.35639 & 198 & -15.96 & 112 & 6.4 \\
\hline VIENNA (HCAT & 48.24861 & 16.35639 & 198 & -9.46 & 52 & 6.4 \\
\hline VIENNA (HCAT & 48.24861 & 16.35639 & 198 & -8.26 & 57 & 6.4 \\
\hline VIENNA (HCAT & 48.24861 & 16.35639 & 198 & -12.12 & 42 & 6.4 \\
\hline VIENNA (HCAT & 48.24861 & 16.35639 & 198 & -11.88 & 71 & 6.4 \\
\hline VIENNA (HCAT & 48.24861 & 16.35639 & 198 & -6.2 & 26 & 6.5 \\
\hline VIENNA (HCAT & 48.24861 & 16.35639 & 198 & -2.05 & 15 & 6.5 \\
\hline VIENNA (HCAT & 48.24861 & 16.35639 & 198 & -7.89 & 25 & 6.6 \\
\hline VIENNA (HCAT & 48.24861 & 16.35639 & 198 & -12.01 & 50 & 6.6 \\
\hline VIENNA (HCAT & 48.24861 & 16.35639 & 198 & -13.37 & 69 & 6.7 \\
\hline VIENNA (HCAT & 48.24861 & 16.35639 & 198 & -12.09 & 25 & 6.7 \\
\hline VIENNA (HCAT & 48.24861 & 16.35639 & 198 & -10.5457 & 35.1 & 6.7 \\
\hline VIENNA (HCAT & 48.24861 & 16.35639 & 198 & -11.3 & 53 & 6.8 \\
\hline VIENNA (HCAT & 48.24861 & 16.35639 & 198 & -9.22 & 8 & 6.8 \\
\hline VIENNA (HCAT & 48.24861 & 16.35639 & 198 & -14.12 & 77 & 6.8 \\
\hline VIENNA (HCAT & 48.24861 & 16.35639 & 198 & -12.43 & 39 & 6.9 \\
\hline VIENNA (HCAT & 48.24861 & 16.35639 & 198 & -12.44 & 21 & 6.9 \\
\hline VIENNA (HCAT & 48.24861 & 16.35639 & 198 & -13.75 & 21 & 6.9 \\
\hline VIENNA (HCAT & 48.24861 & 16.35639 & 198 & -17.43 & 111 & 7 \\
\hline VIENNA (HCAT & 48.24861 & 16.35639 & 198 & -13.42 & 32 & \\
\hline VIENNA (HCAT & 48.24861 & 16.35639 & 198 & -10.9 & 67 & \\
\hline VIENNA (HCAT & 48.24861 & 16.35639 & 198 & -8.35 & 67 & 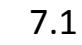 \\
\hline VIENNA (HCAT & 48.24861 & 16.35639 & 198 & -9.29 & 1 & \\
\hline
\end{tabular}




\begin{tabular}{|c|c|c|c|c|c|c|}
\hline VIENNA (HCAT & 48.24861 & 16.35639 & 198 & -11.41 & 28 & 7.2 \\
\hline VIENNA (HCAT & 48.24861 & 16.35639 & 198 & -10.18 & 65 & 7.2 \\
\hline VIENNA (HCAT & 48.24861 & 16.35639 & 198 & -10.13 & 60 & 7.2 \\
\hline VIENNA (HCAT & 48.24861 & 16.35639 & 198 & -6.98 & 44 & 7.3 \\
\hline VIENNA (HCAT & 48.24861 & 16.35639 & 198 & -12.21 & 125 & \\
\hline VIENNA (HCAT & 48.24861 & 16.35639 & 198 & -11.25 & 105 & .4 \\
\hline VIENNA (HCAT & 48.24861 & 16.35639 & 198 & -11.21 & 67 & \\
\hline VIENNA (HCAT & 48.24861 & 16.35639 & 198 & -14.7711 & 36 & .5 \\
\hline VIENNA (HCAT & 48.24861 & 16.35639 & 198 & -11.43 & 31 & .6 \\
\hline VIENNA (HCAT & 48.24861 & 16.35639 & 198 & -13.78 & 90 & .6 \\
\hline VIENNA (HCAT & 48.24861 & 16.35639 & 198 & -8.15 & 63 & .7 \\
\hline VIENNA (HCAT & 48.24861 & 16.35639 & 198 & -8.6 & 30 & 7.8 \\
\hline VIENNA (HCAT & 48.24861 & 16.35639 & 198 & -7.55 & 32 & .8 \\
\hline VIENNA (HCAT & 48.24861 & 16.35639 & 198 & -9.14945 & 23 & 7.8 \\
\hline VIENNA (HCAT & 48.24861 & 16.35639 & 198 & -14.82 & 36 & \\
\hline VIENNA (HCAT & 48.24861 & 16.35639 & 198 & -5.41 & 27 & 8.1 \\
\hline VIENNA (HCAT & 48.24861 & 16.35639 & 198 & -9.67 & 34 & 5.1 \\
\hline VIENNA (HCAT & 48.24861 & 16.35639 & 198 & -13.23 & 34 & .2 \\
\hline VIENNA (HCAT & 48.24861 & 16.35639 & 198 & -7.25 & 10 & .2 \\
\hline VIENNA (HCAT & 48.24861 & 16.35639 & 198 & -14.17 & 40 & 3.2 \\
\hline VIENNA (HCAT & 48.24861 & 16.35639 & 198 & -8.61 & 15 & 8.3 \\
\hline VIENNA (HCAT & 48.24861 & 16.35639 & 198 & -7.15 & 18 & 2 \\
\hline VIENNA (HCAT & 48.24861 & 16.35639 & 198 & -8 & 48 & 8.4 \\
\hline VIENNA (HCAT & 48.24861 & 16.35639 & 198 & -15.48 & 129 & 3.5 \\
\hline VIENNA (HCAT & 48.24861 & 16.35639 & 198 & -6.98 & 30 & 8.5 \\
\hline VIENNA (HCAT & 48.24861 & 16.35639 & 198 & -8.88 & 37 & 8.5 \\
\hline VIENNA (HCAT & 48.24861 & 16.35639 & 198 & -14.76 & 72 & 6 \\
\hline VIENNA (HCAT & 48.24861 & 16.35639 & 198 & -8.41 & 21 & 8.7 \\
\hline VIENNA (HCAT & 48.24861 & 16.35639 & 198 & -5.74 & 23 & 8.7 \\
\hline VIENNA (HCAT & 48.24861 & 16.35639 & 198 & -6.2 & 36 & 8.8 \\
\hline VIENNA (HCAT & 48.24861 & 16.35639 & 198 & -9.5 & 30 & $8 . \varepsilon$ \\
\hline VIENNA (HCAT & 48.24861 & 16.35639 & 198 & -9.495 & 71 & 8.8 \\
\hline VIENNA (HCAT & 48.24861 & 16.35639 & 198 & -11.3 & 34 & 8.5 \\
\hline VIENNA (HCAT & 48.24861 & 16.35639 & 198 & -12.9 & 132 & \\
\hline VIENNA (HCAT & 48.24861 & 16.35639 & 198 & -9.46 & 52 & \\
\hline VIENNA (HCAT & 48.24861 & 16.35639 & 198 & -10.95 & 92 & 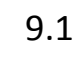 \\
\hline VIENNA (HCAT & 48.24861 & 16.35639 & 198 & -12.84 & 69 & 9.1 \\
\hline VIENNA (HCAT & 48.24861 & 16.35639 & 198 & -10.7 & 131 & .2 \\
\hline VIENNA (HCAT & 48.24861 & 16.35639 & 198 & -10.2 & 28 & 7.2 \\
\hline VIENNA (HCAT & 48.24861 & 16.35639 & 198 & -12.81 & 12 & 9.2 \\
\hline VIENNA (HCAT & 48.24861 & 16.35639 & 198 & -9.53 & 86 & 9.3 \\
\hline VIENNA (HCAT & 48.24861 & 16.35639 & 198 & -11.56 & 88 & 9.3 \\
\hline VIENNA (HCAT & 48.24861 & 16.35639 & 198 & -7.36 & 30 & 9.3 \\
\hline VIENNA (HCAT & 48.24861 & 16.35639 & 198 & -7.1 & 33 & 9.4 \\
\hline VIENNA (HCAT & 48.24861 & 16.35639 & 198 & -11.41 & 40 & 9. \\
\hline VIENNA (HCAT & 48.24861 & 16.35639 & 198 & -7.13 & 48 & \\
\hline VIENNA (HCAT & 48.24861 & 16.35639 & 198 & -10.14 & 50 & 9.5 \\
\hline VIENNA (HCAT & 48.24861 & 16.35639 & 198 & -9.05 & 51 & \\
\hline VIENNA (HCAT & 48.24861 & 16.35639 & 198 & -11.25 & 60 & $9 .($ \\
\hline NNA (HC AT & 61 & 16.35639 & 198 & -13.33 & 3 & \\
\hline
\end{tabular}




\begin{tabular}{|c|c|c|c|c|c|c|}
\hline VIENNA (HCAT & 48.24861 & 16.35639 & 198 & -9.43 & 86 & 9.7 \\
\hline VIENNA (HCAT & 48.24861 & 16.35639 & 198 & -5.36 & 16 & 9.7 \\
\hline VIENNA (HCAT & 48.24861 & 16.35639 & 198 & -9.78 & 43 & 9.8 \\
\hline VIENNA (HCAT & 48.24861 & 16.35639 & 198 & -10.64 & 88 & 9.8 \\
\hline VIENNA (HCAT & 48.24861 & 16.35639 & 198 & -9.12 & 46 & 9.9 \\
\hline VIENNA (HCAT & 48.24861 & 16.35639 & 198 & -9.49 & 21 & 9.9 \\
\hline VIENNA (HCAT & 48.24861 & 16.35639 & 198 & -12.28 & 111 & 9.9 \\
\hline VIENNA (HCAT & 48.24861 & 16.35639 & 198 & -11.59 & 80 & 9.9 \\
\hline VIENNA (HCAT & 48.24861 & 16.35639 & 198 & -11.8 & 49 & 10 \\
\hline VIENNA (HCAT & 48.24861 & 16.35639 & 198 & -7.6 & 24 & 10 \\
\hline VIENNA (HCAT & 48.24861 & 16.35639 & 198 & -10.52 & 19 & 10 \\
\hline VIENNA (HCAT & 48.24861 & 16.35639 & 198 & -8.25 & 27 & 10 \\
\hline VIENNA (HCAT & 48.24861 & 16.35639 & 198 & -9.61829 & 73 & 10 \\
\hline VIENNA (HCAT & 48.24861 & 16.35639 & 198 & -7.26 & 32 & 10.1 \\
\hline VIENNA (HCAT & 48.24861 & 16.35639 & 198 & -7.7 & 27 & 10.1 \\
\hline VIENNA (HCAT & 48.24861 & 16.35639 & 198 & -7.93 & 57 & 10.1 \\
\hline VIENNA (HCAT & 48.24861 & 16.35639 & 198 & -3.721 & 73 & 10.1 \\
\hline VIENNA (HCAT & 48.24861 & 16.35639 & 198 & -5.83 & 11 & 10.2 \\
\hline VIENNA (HCAT & 48.24861 & 16.35639 & 198 & -9.14 & 66 & 10.2 \\
\hline VIENNA (HCAT & 48.24861 & 16.35639 & 198 & -11.94 & 45 & 10.2 \\
\hline VIENNA (HCAT & 48.24861 & 16.35639 & 198 & -11.65 & 100 & 10.3 \\
\hline VIENNA (HCAT & 48.24861 & 16.35639 & 198 & -9.17 & 33 & 10.4 \\
\hline VIENNA (HCAT & 48.24861 & 16.35639 & 198 & -8.33 & 21 & 10.5 \\
\hline VIENNA (HCAT & 48.24861 & 16.35639 & 198 & -7.21 & 16 & 10.5 \\
\hline VIENNA (HCAT & 48.24861 & 16.35639 & 198 & -6.64 & 11 & 10.5 \\
\hline VIENNA (HCAT & 48.24861 & 16.35639 & 198 & -7.58 & 34 & 10.5 \\
\hline VIENNA (HCAT & 48.24861 & 16.35639 & 198 & -7.75 & 57 & 10.6 \\
\hline VIENNA (HCAT & 48.24861 & 16.35639 & 198 & -9.81 & 37 & 10.6 \\
\hline VIENNA (HCAT & 48.24861 & 16.35639 & 198 & -8.01 & 93 & 10.6 \\
\hline VIENNA (HCAT & 48.24861 & 16.35639 & 198 & -7.73 & 24 & 10.6 \\
\hline VIENNA (HCAT & 48.24861 & 16.35639 & 198 & -6.23 & 18 & 10.7 \\
\hline VIENNA (HCAT & 48.24861 & 16.35639 & 198 & -9.76 & 44 & 10.7 \\
\hline VIENNA (HCAT & 48.24861 & 16.35639 & 198 & -7.53 & 27 & 10.7 \\
\hline VIENNA (HCAT & 48.24861 & 16.35639 & 198 & -6.975 & 15 & 10.7 \\
\hline VIENNA (HCAT & 48.24861 & 16.35639 & 198 & -5.29 & 3 & 10.7 \\
\hline VIENNA (HCAT & 48.24861 & 16.35639 & 198 & -8.56 & 15 & 10.8 \\
\hline VIENNA (HCAT & 48.24861 & 16.35639 & 198 & -5.79 & 28 & 10.8 \\
\hline VIENNA (HCAT & 48.24861 & 16.35639 & 198 & -9.19 & 88 & 10.8 \\
\hline VIENNA (HCAT & 48.24861 & 16.35639 & 198 & -9.5 & 19 & 10.8 \\
\hline VIENNA (HCAT & 48.24861 & 16.35639 & 198 & -11.33 & 79 & 10.8 \\
\hline VIENNA (HCAT & 48.24861 & 16.35639 & 198 & -9.10668 & 91 & 10.8 \\
\hline VIENNA (HCAT & 48.24861 & 16.35639 & 198 & -8.5 & 36 & 10.9 \\
\hline VIENNA (HCAT & 48.24861 & 16.35639 & 198 & -4.57 & 13 & 10.9 \\
\hline VIENNA (HCAT & 48.24861 & 16.35639 & 198 & -9.8 & 61 & 10.9 \\
\hline VIENNA ( HCAT & 48.24861 & 16.35639 & 198 & -10.43 & 47 & 11 \\
\hline VIENNA (HCAT & 48.24861 & 16.35639 & 198 & -7.44 & 25 & 11 \\
\hline VIENNA (HCAT & 48.24861 & 16.35639 & 198 & -8.84 & 53 & 11 \\
\hline VIENNA (HCAT & 48.24861 & 16.35639 & 198 & -10.88 & 26 & 11 \\
\hline VIENNA (HCAT & 48.24861 & 16.35639 & 198 & -7.86 & 27 & 11 \\
\hline VIENNA (HCAT & 48.24861 & 16.35639 & 198 & -5.4 & 28 & 12 \\
\hline
\end{tabular}




\begin{tabular}{|c|c|c|c|c|c|c|}
\hline VIENNA (HC AT & 48.24861 & 16.35639 & 198 & -10.46 & 22 & 11.2 \\
\hline VIENNA (HCAT & 48.24861 & 16.35639 & 198 & -10.29 & 49 & 11.2 \\
\hline VIENNA (HC AT & 48.24861 & 16.35639 & 198 & -8.87 & 39 & 11.2 \\
\hline VIENNA (HCAT & 48.24861 & 16.35639 & 198 & -10.47 & 29 & 11.2 \\
\hline VIENNA (HC AT & 48.24861 & 16.35639 & 198 & -6.71 & 22 & 11.2 \\
\hline VIENNA (HC AT & 48.24861 & 16.35639 & 198 & -6.54 & 44 & 11.2 \\
\hline VIENNA (HCAT & 48.24861 & 16.35639 & 198 & -5.1 & 11 & 11.3 \\
\hline VIENNA (HC AT & 48.24861 & 16.35639 & 198 & -12.2 & 64 & 11.5 \\
\hline VIENNA (HC AT & 48.24861 & 16.35639 & 198 & -6.71 & 8 & 11.5 \\
\hline VIENNA (HCAT & 48.24861 & 16.35639 & 198 & -10.96 & 14 & 11.5 \\
\hline VIENNA (HC AT & 48.24861 & 16.35639 & 198 & -8.9 & 22 & 11.5 \\
\hline VIENNA (HC AT & 48.24861 & 16.35639 & 198 & -13.8 & 59 & 11.6 \\
\hline VIENNA (HCAT & 48.24861 & 16.35639 & 198 & -8.11 & 72 & 11.6 \\
\hline VIENNA (HCAT & 48.24861 & 16.35639 & 198 & -10.84 & 48 & 11.7 \\
\hline VIENNA (HC AT & 48.24861 & 16.35639 & 198 & -16.03 & 14 & 1.7 \\
\hline VIENNA (HC AT & 48.24861 & 16.35639 & 198 & -12.39 & 30 & 11.8 \\
\hline VIENNA (HCAT & 48.24861 & 16.35639 & 198 & -8 & 39 & 12 \\
\hline VIENNA (HC AT & 48.24861 & 16.35639 & 198 & -7.51 & 67 & 12 \\
\hline VIENNA (HC AT & 48.24861 & 16.35639 & 198 & -12.37 & 179 & 12 \\
\hline VIENNA (HC AT & 48.24861 & 16.35639 & 198 & -8.5 & 15 & 2.1 \\
\hline VIENNA (HCAT & 48.24861 & 16.35639 & 198 & -8.04 & 20 & 12.1 \\
\hline VIENNA (HC AT & 48.24861 & 16.35639 & 198 & -7.05 & 64 & \\
\hline VIENNA (HC AT & 48.24861 & 16.35639 & 198 & -7.53 & 37 & 12.2 \\
\hline VIENNA (HCAT & 48.24861 & 16.35639 & 198 & -10.19 & 136 & 12.3 \\
\hline VIENNA (HC AT & 48.24861 & 16.35639 & 198 & -8.93 & 18 & 12.5 \\
\hline VIENNA (HC AT & 48.24861 & 16.35639 & 198 & -6.3 & 48 & 12.6 \\
\hline VIENNA (HC AT & 48.24861 & 16.35639 & 198 & -6.62 & 66 & 12.6 \\
\hline VIENNA (HCAT & 48.24861 & 16.35639 & 198 & -8.29 & 56 & 12.7 \\
\hline VIENNA (HC AT & 48.24861 & 16.35639 & 198 & -5.94299 & 43 & 13 \\
\hline VIENNA (HCAT & 48.24861 & 16.35639 & 198 & -5.59 & 29 & 13 \\
\hline VIENNA (HCAT & 48.24861 & 16.35639 & 198 & -11.56 & 106 & 13.1 \\
\hline VIENNA (HC AT & 48.24861 & 16.35639 & 198 & -7.2 & 60 & 13.2 \\
\hline VIENNA (HC AT & 48.24861 & 16.35639 & 198 & -1.2 & 84 & 13.2 \\
\hline VIENNA (HCAT & 48.24861 & 16.35639 & 198 & -8.2 & 131 & 13.2 \\
\hline VIENNA (HC AT & 48.24861 & 16.35639 & 198 & -9.69 & 98 & 13.2 \\
\hline VIENNA (HCAT & 48.24861 & 16.35639 & 198 & -5.96 & 9 & 13.2 \\
\hline VIENNA (HCAT & 48.24861 & 16.35639 & 198 & -8.21 & 1 & 13.2 \\
\hline VIENNA (HCAT & 48.24861 & 16.35639 & 198 & -7.23 & 30 & 13.3 \\
\hline VIENNA (HC AT & 48.24861 & 16.35639 & 198 & -7.61 & 20 & 13.4 \\
\hline VIENNA (HC AT & 48.24861 & 16.35639 & 198 & -16.2 & 54 & 13.5 \\
\hline VIENNA (HCAT & 48.24861 & 16.35639 & 198 & -8.23 & 12 & 13.5 \\
\hline VIENNA (HCAT & 48.24861 & 16.35639 & 198 & -6.22 & 44 & 13.6 \\
\hline VIENNA (HC AT & 48.24861 & 16.35639 & 198 & -8.46 & 99 & 13.6 \\
\hline VIENNA (HCAT & 48.24861 & 16.35639 & 198 & -9.03 & 195 & 13.6 \\
\hline VIENNA (HCAT & 48.24861 & 16.35639 & 198 & -8.8 & 56 & 13.7 \\
\hline VIENNA (HC AT & 48.24861 & 16.35639 & 198 & -7.95 & 69 & 13.8 \\
\hline VIENNA (HC AT & 48.24861 & 16.35639 & 198 & -9.5 & 51 & 14.1 \\
\hline VIENNA (HC AT & 48.24861 & 16.35639 & 198 & -7.57 & 47 & 14.1 \\
\hline VIENNA (HCAT & 48.24861 & 16.35639 & 198 & -9.32 & 128 & 14 \\
\hline NNA (HC AT & 61 & .35639 & 198 & .08 & 1 & \\
\hline
\end{tabular}




\begin{tabular}{|c|c|c|c|c|c|c|}
\hline VIENNA (HCAT & 48.24861 & 16.35639 & 198 & -9.14246 & 65 & 14.2 \\
\hline VIENNA (HCAT & 48.24861 & 16.35639 & 198 & -9.25 & 55 & 14.3 \\
\hline VIENNA (HCAT & 48.24861 & 16.35639 & 198 & -5.73 & 5 & 14.3 \\
\hline VIENNA (HCAT & 48.24861 & 16.35639 & 198 & -6.1 & 25 & 14.4 \\
\hline VIENNA (HCAT & 48.24861 & 16.35639 & 198 & -10.92 & 79 & 14.4 \\
\hline VIENNA (HCAT & 48.24861 & 16.35639 & 198 & -9.49 & 44 & 14.5 \\
\hline VIENNA (HCAT & 48.24861 & 16.35639 & 198 & -11.96 & 62 & 14.5 \\
\hline VIENNA (HCAT & 48.24861 & 16.35639 & 198 & -10.16 & 120 & 14.6 \\
\hline VIENNA (HCAT & 48.24861 & 16.35639 & 198 & -7.94224 & 169 & 14.6 \\
\hline VIENNA (HCAT & 48.24861 & 16.35639 & 198 & -7.98 & 40 & 14.7 \\
\hline VIENNA (HCAT & 48.24861 & 16.35639 & 198 & -8.02 & 69 & 14.7 \\
\hline VIENNA (HCAT & 48.24861 & 16.35639 & 198 & -5.95 & 38 & 14.7 \\
\hline VIENNA (HCAT & 48.24861 & 16.35639 & 198 & -7.2 & 70 & 14.8 \\
\hline VIENNA (HCAT & 48.24861 & 16.35639 & 198 & -7.1 & 68 & 14.9 \\
\hline VIENNA (HCAT & 48.24861 & 16.35639 & 198 & -6.94 & 44 & 14.9 \\
\hline VIENNA (HCAT & 48.24861 & 16.35639 & 198 & -7.22 & 35 & 14.9 \\
\hline VIENNA (HCAT & 48.24861 & 16.35639 & 198 & -7.69 & 58 & 14.9 \\
\hline VIENNA (HCAT & 48.24861 & 16.35639 & 198 & -7.58 & 76 & 14.9 \\
\hline VIENNA (HCAT & 48.24861 & 16.35639 & 198 & -6.83 & 189 & 14.9 \\
\hline VIENNA (HCAT & 48.24861 & 16.35639 & 198 & -10.5 & 93 & 14.9 \\
\hline VIENNA (HCAT & 48.24861 & 16.35639 & 198 & -7.6 & 69 & 15 \\
\hline VIENNA (HCAT & 48.24861 & 16.35639 & 198 & -8.86 & 93 & 15 \\
\hline VIENNA (HCAT & 48.24861 & 16.35639 & 198 & -4.92 & 21 & 15 \\
\hline VIENNA (HCAT & 48.24861 & 16.35639 & 198 & -6.22 & 89 & 15 \\
\hline VIENNA (HCAT & 48.24861 & 16.35639 & 198 & -8.62 & 130 & 15 \\
\hline VIENNA (HCAT & 48.24861 & 16.35639 & 198 & -8.12 & 39 & 15.1 \\
\hline VIENNA (HCAT & 48.24861 & 16.35639 & 198 & -9.53 & 33 & 15.1 \\
\hline VIENNA (HCAT & 48.24861 & 16.35639 & 198 & -7.98 & 59 & 15.1 \\
\hline VIENNA (HCAT & 48.24861 & 16.35639 & 198 & -13.74 & 92 & 15.1 \\
\hline VIENNA (HCAT & 48.24861 & 16.35639 & 198 & -12.3 & 43 & 15.2 \\
\hline VIENNA (HCAT & 48.24861 & 16.35639 & 198 & -7.96 & 46 & 15.2 \\
\hline VIENNA (HCAT & 48.24861 & 16.35639 & 198 & -9.7 & 91 & 15.3 \\
\hline VIENNA (HCAT & 48.24861 & 16.35639 & 198 & -1.84 & 45 & 15.3 \\
\hline VIENNA (HCAT & 48.24861 & 16.35639 & 198 & -6.27 & 24 & 15.3 \\
\hline VIENNA (HCAT & 48.24861 & 16.35639 & 198 & -7.1 & 19 & 15.4 \\
\hline VIENNA (HCAT & 48.24861 & 16.35639 & 198 & -8.67 & 62 & 15.4 \\
\hline VIENNA (HCAT & 48.24861 & 16.35639 & 198 & -11.08 & 120 & 15.4 \\
\hline VIENNA (HCAT & 48.24861 & 16.35639 & 198 & -3.93 & 21 & 15.4 \\
\hline VIENNA (HCAT & 48.24861 & 16.35639 & 198 & -6.92 & 40 & 15.4 \\
\hline VIENNA (HCAT & 48.24861 & 16.35639 & 198 & -4.29 & 48 & 15.4 \\
\hline VIENNA (HCAT & 48.24861 & 16.35639 & 198 & -7.3 & 48 & 15.6 \\
\hline VIENNA (HCAT & 48.24861 & 16.35639 & 198 & -6.83 & 14 & 15.6 \\
\hline VIENNA (HCAT & 48.24861 & 16.35639 & 198 & -8.81 & 99 & 15.6 \\
\hline VIENNA (HCAT & 48.24861 & 16.35639 & 198 & -8.37 & 56 & 15.6 \\
\hline VIENNA (HCAT & 48.24861 & 16.35639 & 198 & -6.48 & 84 & 15.6 \\
\hline VIENNA (HCAT & 48.24861 & 16.35639 & 198 & -6.32 & 17 & 15.7 \\
\hline VIENNA (HCAT & 48.24861 & 16.35639 & 198 & -8.45 & 43 & 15.7 \\
\hline VIENNA (HCAT & 48.24861 & 16.35639 & 198 & -7.96 & 132 & 15.7 \\
\hline VIENNA (HCAT & 48.24861 & 16.35639 & 198 & -7.49 & 44 & 15.8 \\
\hline VIENNA (HCAT & 48.24861 & 16.35639 & 198 & -6.75 & 49 & 15.8 \\
\hline
\end{tabular}




\begin{tabular}{|c|c|c|c|c|c|c|}
\hline VIENNA (HCAT & 48.24861 & 16.35639 & 198 & -7.85 & 8 & 15.8 \\
\hline VIENNA (HCAT & 48.24861 & 16.35639 & 198 & -6.6 & 20 & 15.9 \\
\hline VIENNA (HCAT & 48.24861 & 16.35639 & 198 & -4.77 & 17 & 15.9 \\
\hline VIENNA (HCAT & 48.24861 & 16.35639 & 198 & -7.73 & 69 & 15.9 \\
\hline VIENNA (HCAT & 48.24861 & 16.35639 & 198 & -7.34 & 52 & 15.9 \\
\hline VIENNA (HCAT & 48.24861 & 16.35639 & 198 & -6.01 & 29 & 15.9 \\
\hline VIENNA (HCAT & 48.24861 & 16.35639 & 198 & -9.59 & 46 & 15.9 \\
\hline VIENNA (HCAT & 48.24861 & 16.35639 & 198 & -7.95 & 71 & 15.9 \\
\hline VIENNA (HCAT & 48.24861 & 16.35639 & 198 & -5.735 & 91 & 15.9 \\
\hline VIENNA (HCAT & 48.24861 & 16.35639 & 198 & -10.15 & 109 & 15.9 \\
\hline VIENNA (HCAT & 48.24861 & 16.35639 & 198 & -9.3 & 30 & 16 \\
\hline VIENNA (HCAT & 48.24861 & 16.35639 & 198 & -8.22463 & & 10 \\
\hline VIENNA (HCAT & 48.24861 & 16.35639 & 198 & -5 & 25 & 16.1 \\
\hline VIENNA (HCAT & 48.24861 & 16.35639 & 198 & -7.82 & 73 & 16.1 \\
\hline VIENNA (HCAT & 48.24861 & 16.35639 & 198 & -8.21 & 42 & 16.1 \\
\hline VIENNA (HCAT & 48.24861 & 16.35639 & 198 & -5.65 & 70 & 16.2 \\
\hline VIENNA (HCAT & 48.24861 & 16.35639 & 198 & -7.58 & 67 & 16.2 \\
\hline VIENNA (HCAT & 48.24861 & 16.35639 & 198 & -8.43 & 57 & 16.2 \\
\hline VIENNA (HCAT & 48.24861 & 16.35639 & 198 & -6.57 & 97 & 16.3 \\
\hline VIENNA (HCAT & 48.24861 & 16.35639 & 198 & -7.02 & 85 & 16.3 \\
\hline VIENNA (HCAT & 48.24861 & 16.35639 & 198 & -7.26 & 85 & 16.3 \\
\hline VIENNA (HCAT & 48.24861 & 16.35639 & 198 & -8 & 49 & 16.4 \\
\hline VIENNA (HCAT & 48.24861 & 16.35639 & 198 & -8.98 & 57 & 16.4 \\
\hline VIENNA (HCAT & 48.24861 & 16.35639 & 198 & -4.83 & 43 & 16.4 \\
\hline VIENNA (HCAT & 48.24861 & 16.35639 & 198 & -7.92 & 44 & 16.4 \\
\hline VIENNA (HCAT & 48.24861 & 16.35639 & 198 & -3.23 & 34 & 16.5 \\
\hline VIENNA (HCAT & 48.24861 & 16.35639 & 198 & -7.83 & 109 & 16.7 \\
\hline VIENNA (HCAT & 48.24861 & 16.35639 & 198 & -8.69 & 81 & 16.7 \\
\hline VIENNA (HCAT & 48.24861 & 16.35639 & 198 & -11.93 & 45 & 16.7 \\
\hline VIENNA (HCAT & 48.24861 & 16.35639 & 198 & -6.52 & 44 & 16.7 \\
\hline VIENNA (HCAT & 48.24861 & 16.35639 & 198 & -7.66 & 89 & 16.8 \\
\hline VIENNA (HCAT & 48.24861 & 16.35639 & 198 & -6.18 & 35 & 16.9 \\
\hline VIENNA (HCAT & 48.24861 & 16.35639 & 198 & -4.55 & 15 & 16.9 \\
\hline VIENNA (HCAT & 48.24861 & 16.35639 & 198 & -4.04 & 38 & 17 \\
\hline VIENNA (HCAT & 48.24861 & 16.35639 & 198 & -6.88 & 39 & 17.2 \\
\hline VIENNA (HCAT & 48.24861 & 16.35639 & 198 & -8.31 & 52 & 17.2 \\
\hline VIENNA (HCAT & 48.24861 & 16.35639 & 198 & -5.9 & 22 & 17.2 \\
\hline VIENNA (HCAT & 48.24861 & 16.35639 & 198 & -6.58 & 51 & 17.2 \\
\hline VIENNA (HCAT & 48.24861 & 16.35639 & 198 & -6.55 & 29 & 17.2 \\
\hline VIENNA (HCAT & 48.24861 & 16.35639 & 198 & -5.42 & 20 & 17.2 \\
\hline VIENNA (HCAT & 48.24861 & 16.35639 & 198 & -5.9 & 57 & 17.3 \\
\hline VIENNA (HCAT & 48.24861 & 16.35639 & 198 & -8.36 & 154 & 17.3 \\
\hline VIENNA (HCAT & 48.24861 & 16.35639 & 198 & -9.47 & 46 & 17.3 \\
\hline VIENNA (HCAT & 48.24861 & 16.35639 & 198 & -8.67 & 156 & 17.4 \\
\hline VIENNA (HCAT & 48.24861 & 16.35639 & 198 & -6.53 & 72 & 17.4 \\
\hline VIENNA (HCAT & 48.24861 & 16.35639 & 198 & -4.83 & 22 & 17.4 \\
\hline VIENNA (HCAT & 48.24861 & 16.35639 & 198 & -8 & 117 & 17.4 \\
\hline VIENNA (HCAT & 48.24861 & 16.35639 & 198 & -8.4 & 47 & 17.4 \\
\hline VIENNA (HCAT & 48.24861 & 16.35639 & 198 & -5.99 & 99 & 17.4 \\
\hline NNA (HC AT & 361 & 5.35639 & 198 & -6.3 & 9 & \\
\hline
\end{tabular}




\begin{tabular}{|c|c|c|c|c|c|c|}
\hline VIENNA (HCAT & 48.24861 & 16.35639 & 198 & -8.14 & 47 & 17.5 \\
\hline VIENNA (HCAT & 48.24861 & 16.35639 & 198 & -6.96 & 17 & 17.5 \\
\hline VIENNA (HCAT & 48.24861 & 16.35639 & 198 & -4.5 & 22 & 17.7 \\
\hline VIENNA (HCAT & 48.24861 & 16.35639 & 198 & -3.42 & 30 & 17.7 \\
\hline VIENNA (HCAT & 48.24861 & 16.35639 & 198 & -8.98 & 44 & 17.7 \\
\hline VIENNA (HCAT & 48.24861 & 16.35639 & 198 & -6.56 & 53 & 17.7 \\
\hline VIENNA (HCAT & 48.24861 & 16.35639 & 198 & -6.24 & 49 & 17.7 \\
\hline VIENNA (HCAT & 48.24861 & 16.35639 & 198 & -9.12 & 212 & 17.7 \\
\hline VIENNA (HCAT & 48.24861 & 16.35639 & 198 & -7.77571 & 21 & 17.7 \\
\hline VIENNA (HCAT & 48.24861 & 16.35639 & 198 & -7.3 & 193 & 17.8 \\
\hline VIENNA (HCAT & 48.24861 & 16.35639 & 198 & -5 & 64 & 17.8 \\
\hline VIENNA (HCAT & 48.24861 & 16.35639 & 198 & -7.52 & 37 & 17.8 \\
\hline VIENNA (HCAT & 48.24861 & 16.35639 & 198 & -6.19 & 112 & 17.8 \\
\hline VIENNA (HCAT & 48.24861 & 16.35639 & 198 & -10.84 & 118 & 17.9 \\
\hline VIENNA (HCAT & 48.24861 & 16.35639 & 198 & -6.86 & 34 & 17.9 \\
\hline VIENNA (HCAT & 48.24861 & 16.35639 & 198 & -6.18 & 68 & 18 \\
\hline VIENNA (HCAT & 48.24861 & 16.35639 & 198 & -7.71 & 30 & 18 \\
\hline VIENNA (HCAT & 48.24861 & 16.35639 & 198 & -5.82 & 44 & 18 \\
\hline VIENNA (HCAT & 48.24861 & 16.35639 & 198 & -7.91 & 125 & 18 \\
\hline VIENNA (HCAT & 48.24861 & 16.35639 & 198 & -7.7 & 133 & 18.1 \\
\hline VIENNA (HCAT & 48.24861 & 16.35639 & 198 & -6.69 & 101 & 18.1 \\
\hline VIENNA (HCAT & 48.24861 & 16.35639 & 198 & -6.06 & 13 & 18.1 \\
\hline VIENNA (HCAT & 48.24861 & 16.35639 & 198 & -8.69 & 36 & 18.1 \\
\hline VIENNA (HCAT & 48.24861 & 16.35639 & 198 & -7.09 & 28 & 18.1 \\
\hline VIENNA (HCAT & 48.24861 & 16.35639 & 198 & -10.44 & 55 & 18.1 \\
\hline VIENNA (HCAT & 48.24861 & 16.35639 & 198 & -7.36 & 26 & 18.2 \\
\hline VIENNA (HCAT & 48.24861 & 16.35639 & 198 & -6.74 & 67 & 18.2 \\
\hline VIENNA (HCAT & 48.24861 & 16.35639 & 198 & -7.81 & 98 & 18.2 \\
\hline VIENNA (HCAT & 48.24861 & 16.35639 & 198 & -7.75 & 108 & 18.2 \\
\hline VIENNA (HCAT & 48.24861 & 16.35639 & 198 & -7.895 & 62 & 18.2 \\
\hline VIENNA (HCAT & 48.24861 & 16.35639 & 198 & -6.41 & 142 & 18.2 \\
\hline VIENNA (HCAT & 48.24861 & 16.35639 & 198 & -4.9 & 52 & 18.3 \\
\hline VIENNA (HCAT & 48.24861 & 16.35639 & 198 & -5.7 & 84 & 18.3 \\
\hline VIENNA (HCAT & 48.24861 & 16.35639 & 198 & -6.37 & 69 & 18.3 \\
\hline VIENNA (HCAT & 48.24861 & 16.35639 & 198 & -4.9 & 52 & 18.4 \\
\hline VIENNA (HCAT & 48.24861 & 16.35639 & 198 & -7.93 & 35 & 18.4 \\
\hline VIENNA (HCAT & 48.24861 & 16.35639 & 198 & -9.13 & 23 & 18.4 \\
\hline VIENNA (HCAT & 48.24861 & 16.35639 & 198 & -4.1 & 83 & 18.5 \\
\hline VIENNA (HCAT & 48.24861 & 16.35639 & 198 & -3.7 & 84 & 18.5 \\
\hline VIENNA (HCAT & 48.24861 & 16.35639 & 198 & -5.84 & 67 & 18.5 \\
\hline VIENNA (HCAT & 48.24861 & 16.35639 & 198 & -9.08 & 73 & 18.5 \\
\hline VIENNA (HCAT & 48.24861 & 16.35639 & 198 & -7.49 & 26 & 18.6 \\
\hline VIENNA (HCAT & 48.24861 & 16.35639 & 198 & -8.77 & 145 & 18.6 \\
\hline VIENNA (HCAT & 48.24861 & 16.35639 & 198 & -7.2 & 53 & 18.7 \\
\hline VIENNA (HCAT & 48.24861 & 16.35639 & 198 & -5.7 & 123 & 18.7 \\
\hline VIENNA (HCAT & 48.24861 & 16.35639 & 198 & -6.85 & 22 & 18.7 \\
\hline VIENNA (HCAT & 48.24861 & 16.35639 & 198 & -6.87 & 61 & 18.7 \\
\hline VIENNA (HCAT & 48.24861 & 16.35639 & 198 & -7.45 & 45 & 18.7 \\
\hline VIENNA (HCAT & 48.24861 & 16.35639 & 198 & -8.37 & 105 & 18.7 \\
\hline VIENNA (HCAT & 48.24861 & 16.35639 & 198 & -6.63 & 73 & 18 \\
\hline
\end{tabular}




\begin{tabular}{|c|c|c|c|c|c|c|}
\hline VIENNA (HCAT & 48.24861 & 16.35639 & 198 & -6.07 & 45 & 18.8 \\
\hline VIENNA (HCAT & 48.24861 & 16.35639 & 198 & -7.72 & 67 & 18.8 \\
\hline VIENNA (HCAT & 48.24861 & 16.35639 & 198 & -7.16 & 66 & 18.9 \\
\hline VIENNA (HCAT & 48.24861 & 16.35639 & 198 & -9.3 & 55 & 19 \\
\hline VIENNA (HCAT & 48.24861 & 16.35639 & 198 & -5.76 & 110 & 19 \\
\hline VIENNA (HCAT & 48.24861 & 16.35639 & 198 & -7.1 & 48 & 19.1 \\
\hline VIENNA (HCAT & 48.24861 & 16.35639 & 198 & -7.53 & 35 & 19.1 \\
\hline VIENNA (HCAT & 48.24861 & 16.35639 & 198 & -6.3 & 56 & 19.1 \\
\hline VIENNA (HCAT & 48.24861 & 16.35639 & 198 & -7.9 & 41 & 19.1 \\
\hline VIENNA (HCAT & 48.24861 & 16.35639 & 198 & -7.13 & 48 & 19.1 \\
\hline VIENNA (HCAT & 48.24861 & 16.35639 & 198 & -7.13 & 60 & 19.1 \\
\hline VIENNA (HCAT & 48.24861 & 16.35639 & 198 & -7.97 & 41 & 19.1 \\
\hline VIENNA (HCAT & 48.24861 & 16.35639 & 198 & -6.39 & 71 & 19.1 \\
\hline VIENNA (HCAT & 48.24861 & 16.35639 & 198 & -8.24 & 245 & 19.1 \\
\hline VIENNA (HCAT & 48.24861 & 16.35639 & 198 & -6.325 & 73 & 19.1 \\
\hline VIENNA (HCAT & 48.24861 & 16.35639 & 198 & -7.11 & 44 & 19.1 \\
\hline VIENNA (HCAT & 48.24861 & 16.35639 & 198 & -7.19 & 55 & 19.2 \\
\hline VIENNA (HCAT & 48.24861 & 16.35639 & 198 & -3.93 & 40 & 19.2 \\
\hline VIENNA (HCAT & 48.24861 & 16.35639 & 198 & -7.81645 & 120 & 19.2 \\
\hline VIENNA (HCAT & 48.24861 & 16.35639 & 198 & -7.92771 & 84 & 19.2 \\
\hline VIENNA (HCAT & 48.24861 & 16.35639 & 198 & -6.78 & 81 & 19.3 \\
\hline VIENNA (HCAT & 48.24861 & 16.35639 & 198 & -4.45 & 44 & 19.4 \\
\hline VIENNA (HCAT & 48.24861 & 16.35639 & 198 & -6.2 & 53 & 19.4 \\
\hline VIENNA (HCAT & 48.24861 & 16.35639 & 198 & -8.03 & 66 & 19.4 \\
\hline VIENNA (HCAT & 48.24861 & 16.35639 & 198 & -8.1714 & 123 & 19.4 \\
\hline VIENNA (HCAT & 48.24861 & 16.35639 & 198 & -6.6 & 28 & 19.5 \\
\hline VIENNA (HCAT & 48.24861 & 16.35639 & 198 & -5.55 & 60 & 19.5 \\
\hline VIENNA (HCAT & 48.24861 & 16.35639 & 198 & -7.55 & 83 & 19.5 \\
\hline VIENNA (HCAT & 48.24861 & 16.35639 & 198 & -9.25 & 130 & 19.5 \\
\hline VIENNA (HCAT & 48.24861 & 16.35639 & 198 & -7.83 & 144 & 19.5 \\
\hline VIENNA (HCAT & 48.24861 & 16.35639 & 198 & -9.66 & 75 & 19.5 \\
\hline VIENNA (HCAT & 48.24861 & 16.35639 & 198 & -9.2 & 85 & 19.6 \\
\hline VIENNA (HCAT & 48.24861 & 16.35639 & 198 & -8.63 & 121 & 19.6 \\
\hline VIENNA (HCAT & 48.24861 & 16.35639 & 198 & -8.46 & 74 & 19.6 \\
\hline VIENNA (HCAT & 48.24861 & 16.35639 & 198 & -10.75 & 33 & 19.6 \\
\hline VIENNA (HCAT & 48.24861 & 16.35639 & 198 & -7.49 & 52 & 19.7 \\
\hline VIENNA (HCAT & 48.24861 & 16.35639 & 198 & -6.37 & 89 & 19.7 \\
\hline VIENNA (HCAT & 48.24861 & 16.35639 & 198 & -6.94 & 38 & 19.7 \\
\hline VIENNA (HCAT & 48.24861 & 16.35639 & 198 & -4.06 & 53 & 19.7 \\
\hline VIENNA (HCAT & 48.24861 & 16.35639 & 198 & -5.98 & 111 & 19.7 \\
\hline VIENNA (HCAT & 48.24861 & 16.35639 & 198 & -8.66 & 58 & 19.7 \\
\hline VIENNA (HCAT & 48.24861 & 16.35639 & 198 & -6.98098 & 113 & 19.8 \\
\hline VIENNA (HCAT & 48.24861 & 16.35639 & 198 & -6.07 & 142 & 20 \\
\hline VIENNA (HCAT & 48.24861 & 16.35639 & 198 & -4.81 & 24 & 20 \\
\hline VIENNA (HCAT & 48.24861 & 16.35639 & 198 & -7.12 & 31 & 20.1 \\
\hline VIENNA (HCAT & 48.24861 & 16.35639 & 198 & -5.45 & 20 & 20.1 \\
\hline VIENNA (HCAT & 48.24861 & 16.35639 & 198 & -8.33 & 33 & 20.1 \\
\hline VIENNA (HCAT & 48.24861 & 16.35639 & 198 & -7.81 & 136 & 20.1 \\
\hline VIENNA (HCAT & 48.24861 & 16.35639 & 198 & -4.26 & 47 & 20.1 \\
\hline NNA (H( AT & 61 & 35639 & 198 & -5.6 & 43 & 20 \\
\hline
\end{tabular}




\begin{tabular}{|c|c|c|c|c|c|c|}
\hline VIENNA (HCAT & 48.24861 & 16.35639 & 198 & -6.6 & 42 & 20.2 \\
\hline VIENNA (HCAT & 48.24861 & 16.35639 & 198 & -6.03 & 114 & 20.3 \\
\hline VIENNA (HCAT & 48.24861 & 16.35639 & 198 & -7.71 & 121 & 20.3 \\
\hline VIENNA (HCAT & 48.24861 & 16.35639 & 198 & -5.49 & 64 & 20.3 \\
\hline VIENNA (HCAT & 48.24861 & 16.35639 & 198 & -5.5 & 23 & 20.3 \\
\hline VIENNA (HCAT & 48.24861 & 16.35639 & 198 & -6.21 & 59 & 20.3 \\
\hline VIENNA (HCAT & 48.24861 & 16.35639 & 198 & -6.04 & 59 & 20.4 \\
\hline VIENNA (HCAT & 48.24861 & 16.35639 & 198 & -5.81 & 39 & 20.4 \\
\hline VIENNA (HCAT & 48.24861 & 16.35639 & 198 & -7.9 & 210 & 20.4 \\
\hline VIENNA (HCAT & 48.24861 & 16.35639 & 198 & -4.21 & 115 & 20.4 \\
\hline VIENNA (HCAT & 48.24861 & 16.35639 & 198 & -6.13 & 96 & 20.4 \\
\hline VIENNA (HCAT & 48.24861 & 16.35639 & 198 & -7.96 & 79 & 20.4 \\
\hline VIENNA (HCAT & 48.24861 & 16.35639 & 198 & -5.46 & 42 & 20.5 \\
\hline VIENNA (HCAT & 48.24861 & 16.35639 & 198 & -6.35 & 29 & 20.5 \\
\hline VIENNA (HCAT & 48.24861 & 16.35639 & 198 & -4.5 & 69 & 20.5 \\
\hline VIENNA (HCAT & 48.24861 & 16.35639 & 198 & -4.56 & 60 & 20.5 \\
\hline VIENNA (HCAT & 48.24861 & 16.35639 & 198 & -6.24 & 69 & 20.5 \\
\hline VIENNA (HCAT & 48.24861 & 16.35639 & 198 & -5.4 & 43 & 20.6 \\
\hline VIENNA (HCAT & 48.24861 & 16.35639 & 198 & -6.99 & 72 & 20.6 \\
\hline VIENNA (HCAT & 48.24861 & 16.35639 & 198 & -6.17 & 25 & 20.6 \\
\hline VIENNA (HCAT & 48.24861 & 16.35639 & 198 & -4.5 & 26 & 20.7 \\
\hline VIENNA (HCAT & 48.24861 & 16.35639 & 198 & -6.11 & 39 & 20.7 \\
\hline VIENNA (HCAT & 48.24861 & 16.35639 & 198 & -8.37 & 64 & 20.7 \\
\hline VIENNA (HCAT & 48.24861 & 16.35639 & 198 & -7.61 & 80 & 20.8 \\
\hline VIENNA (HCAT & 48.24861 & 16.35639 & 198 & -3.96 & 50 & 20.8 \\
\hline VIENNA (HCAT & 48.24861 & 16.35639 & 198 & -2.3 & 37 & 20.9 \\
\hline VIENNA (HCAT & 48.24861 & 16.35639 & 198 & -5.52 & 78 & 20.9 \\
\hline VIENNA (HCAT & 48.24861 & 16.35639 & 198 & -6.86 & 81 & 21 \\
\hline VIENNA (HCAT & 48.24861 & 16.35639 & 198 & -4.9 & 85 & 21 \\
\hline VIENNA (HCAT & 48.24861 & 16.35639 & 198 & -5.2 & 66 & 21.1 \\
\hline VIENNA (HCAT & 48.24861 & 16.35639 & 198 & -5.60554 & 28 & 21.1 \\
\hline VIENNA (HCAT & 48.24861 & 16.35639 & 198 & -6.58 & 34 & 21.3 \\
\hline VIENNA (HCAT & 48.24861 & 16.35639 & 198 & -6.39 & 56 & 21.3 \\
\hline VIENNA (HCAT & 48.24861 & 16.35639 & 198 & -5.91 & 15 & 21.3 \\
\hline VIENNA (HCAT & 48.24861 & 16.35639 & 198 & -5.02 & 60 & 21.3 \\
\hline VIENNA (HCAT & 48.24861 & 16.35639 & 198 & -6.38 & 47 & 21.3 \\
\hline VIENNA (HCAT & 48.24861 & 16.35639 & 198 & -6.6 & 11 & 21.4 \\
\hline VIENNA (HCAT & 48.24861 & 16.35639 & 198 & -4.24 & 79 & 21.4 \\
\hline VIENNA (HCAT & 48.24861 & 16.35639 & 198 & -4.45 & 53 & 21.4 \\
\hline VIENNA (HCAT & 48.24861 & 16.35639 & 198 & -6.01 & 149 & 21.4 \\
\hline VIENNA (HCAT & 48.24861 & 16.35639 & 198 & -10.36 & 48 & 21.5 \\
\hline VIENNA (HCAT & 48.24861 & 16.35639 & 198 & -3.88 & 130 & 21.5 \\
\hline VIENNA (HCAT & 48.24861 & 16.35639 & 198 & -4.67 & 44 & 21.6 \\
\hline VIENNA (HCAT & 48.24861 & 16.35639 & 198 & -7.78 & 41 & 21.6 \\
\hline VIENNA (HCAT & 48.24861 & 16.35639 & 198 & -6.02 & 52 & 21.7 \\
\hline VIENNA (HCAT & 48.24861 & 16.35639 & 198 & -7.66 & 70 & 21.8 \\
\hline VIENNA (HCAT & 48.24861 & 16.35639 & 198 & -7.69 & 80 & 21.9 \\
\hline VIENNA (HCAT & 48.24861 & 16.35639 & 198 & -5.8 & 91 & 21.9 \\
\hline VIENNA (HCAT & 48.24861 & 16.35639 & 198 & -7.92 & 55 & 22 \\
\hline VIENNA (HCAT & 48.24861 & 16.35639 & 198 & -5.37 & 85 & 22.2 \\
\hline
\end{tabular}




\begin{tabular}{|c|c|c|c|c|c|c|c|}
\hline \multicolumn{2}{|c|}{ VIENNA (HCAT } & 48.24861 & 16.35639 & 198 & -3.4 & 32 & 22.2 \\
\hline \multicolumn{2}{|c|}{ VIENNA (HCAT } & 48.24861 & 16.35639 & 198 & -5.36 & 66 & 22.2 \\
\hline \multicolumn{2}{|c|}{ VIENNA (HCAT } & 48.24861 & 16.35639 & 198 & -6.72578 & 88 & 22.3 \\
\hline \multicolumn{2}{|c|}{ VIENNA (HCAT } & 48.24861 & 16.35639 & 198 & -4.23 & 30 & 22.5 \\
\hline \multicolumn{2}{|c|}{ VIENNA (HCAT } & 48.24861 & 16.35639 & 198 & -4.62 & 42 & 22.6 \\
\hline \multicolumn{2}{|c|}{ VIENNA (HCAT } & 48.24861 & 16.35639 & 198 & -5.37 & 128 & 22.7 \\
\hline \multicolumn{2}{|c|}{ VIENNA (HCAT } & 48.24861 & 16.35639 & 198 & -4.63 & 24 & 22.9 \\
\hline \multicolumn{2}{|c|}{ VIENNA (HCAT } & 48.24861 & 16.35639 & 198 & -8.9 & 11 & 22.9 \\
\hline \multicolumn{2}{|c|}{ VIENNA (HCAT } & 48.24861 & 16.35639 & 198 & -6.2 & 76 & 23.2 \\
\hline \multicolumn{2}{|c|}{ VIENNA (HCAT } & 48.24861 & 16.35639 & 198 & -3.13 & 6 & 23.3 \\
\hline \multicolumn{2}{|c|}{ VIENNA (HCAT } & 48.24861 & 16.35639 & 198 & -6.69 & 48 & 23.4 \\
\hline \multicolumn{2}{|c|}{ VIENNA (HCAT } & 48.24861 & 16.35639 & 198 & -3.59 & 20 & 23.5 \\
\hline \multicolumn{2}{|c|}{ VIENNA (HCAT } & 48.24861 & 16.35639 & 198 & -6.71 & 44 & 23.6 \\
\hline \multicolumn{2}{|c|}{ VIENNA (HCAT } & 48.24861 & 16.35639 & 198 & -5.38 & 38 & 23.9 \\
\hline \multicolumn{2}{|c|}{ VIENNA (HCAT } & 48.24861 & 16.35639 & 198 & -6.03 & 19 & 24.4 \\
\hline ZAGREB & $\mathrm{HR}$ & 45.80667 & 15.97 & 165 & -14.82 & 40 & -3.4 \\
\hline ZAGREB & $\mathrm{HR}$ & 45.80667 & 15.97 & 165 & -15.05 & 90 & -2.1 \\
\hline ZAGREB & $H R$ & 45.80667 & 15.97 & 165 & -13.74 & 81 & -1.8 \\
\hline ZAGREB & $H R$ & 45.80667 & 15.97 & 165 & -13.56 & 42 & -1.5 \\
\hline ZAGREB & $\mathrm{HR}$ & 45.80667 & 15.97 & 165 & -12.11 & 42 & -1.3 \\
\hline ZAGREB & $H R$ & 45.80667 & 15.97 & 165 & -12.71 & 32 & -0.8 \\
\hline ZAGREB & $\mathrm{HR}$ & 45.80667 & 15.97 & 165 & -15.21 & 31 & 0.2 \\
\hline ZAGREB & $\mathrm{HR}$ & 45.80667 & 15.97 & 165 & -11.41 & 12 & 0.2 \\
\hline ZAGREB & $\mathrm{HR}$ & 45.80667 & 15.97 & 165 & -13.9 & 96 & 0.7 \\
\hline ZAGREB & $H R$ & 45.80667 & 15.97 & 165 & -10.42 & 31 & 0.7 \\
\hline ZAGREB & $H R$ & 45.80667 & 15.97 & 165 & -7.87 & 25 & 1.1 \\
\hline ZAGREB & $\mathrm{HR}$ & 45.80667 & 15.97 & 165 & -13.07 & 54 & 1.3 \\
\hline ZAGREB & $\mathrm{HR}$ & 45.80667 & 15.97 & 165 & -13.71 & 174 & 1.5 \\
\hline ZAGREB & $H R$ & 45.80667 & 15.97 & 165 & -12.52 & 61 & 1.7 \\
\hline ZAGREB & $H R$ & 45.80667 & 15.97 & 165 & -11.9 & 72 & 1.8 \\
\hline ZAGREB & $H R$ & 45.80667 & 15.97 & 165 & -12.6 & 146 & 1.9 \\
\hline ZAGREB & $H R$ & 45.80667 & 15.97 & 165 & -10.99 & 30 & 1.9 \\
\hline ZAGREB & $H R$ & 45.80667 & 15.97 & 165 & -16.5 & 79 & 2 \\
\hline ZAGREB & $\mathrm{HR}$ & 45.80667 & 15.97 & 165 & -10.96 & 40 & 2.1 \\
\hline ZAGREB & $H R$ & 45.80667 & 15.97 & 165 & -13.08 & 59 & 2.1 \\
\hline ZAGREB & $\mathrm{HR}$ & 45.80667 & 15.97 & 165 & -12.74 & 57 & 2.2 \\
\hline ZAGREB & $\mathrm{HR}$ & 45.80667 & 15.97 & 165 & -13.43 & 65 & 2.3 \\
\hline ZAGREB & $\mathrm{HR}$ & 45.80667 & 15.97 & 165 & -14.24 & 22 & 2.6 \\
\hline ZAGREB & $H R$ & 45.80667 & 15.97 & 165 & -10.92 & 32 & 2.6 \\
\hline ZAGREB & $H R$ & 45.80667 & 15.97 & 165 & -9.75 & 3 & 2.7 \\
\hline ZAGREB & $\mathrm{HR}$ & 45.80667 & 15.97 & 165 & -10.19 & 38 & 2.8 \\
\hline ZAGREB & $\mathrm{HR}$ & 45.80667 & 15.97 & 165 & -8.79 & 41 & 2.8 \\
\hline ZAGREB & $H R$ & 45.80667 & 15.97 & 165 & -11.43 & 16 & 2.9 \\
\hline ZAGREB & $H R$ & 45.80667 & 15.97 & 165 & -14 & 176 & 2.9 \\
\hline ZAGREB & $\mathrm{HR}$ & 45.80667 & 15.97 & 165 & -12.1 & 8 & 3.1 \\
\hline ZAGREB & $\mathrm{HR}$ & 45.80667 & 15.97 & 165 & -8.13 & 26 & 3.2 \\
\hline ZAGREB & $H R$ & 45.80667 & 15.97 & 165 & -12.5 & 94 & 3.3 \\
\hline ZAGREB & $\mathrm{HR}$ & 45.80667 & 15.97 & 165 & -11.3 & 84 & 3.3 \\
\hline ZAGREB & $\mathrm{HR}$ & 45.80667 & 15.97 & 165 & -10.87 & 79 & 3.5 \\
\hline EB & $\mathrm{HR}$ & .80667 & 15.97 & 165 & -7.21 & 26 & 3 \\
\hline
\end{tabular}




\begin{tabular}{|c|c|c|c|c|c|c|c|}
\hline ZAGREB & $\mathrm{HR}$ & 45.80667 & 15.97 & 165 & -11.5 & 29 & 3.8 \\
\hline ZAGREB & $H R$ & 45.80667 & 15.97 & 165 & -11.29 & 142 & 4.2 \\
\hline ZAGREB & $H R$ & 45.80667 & 15.97 & 165 & -9.57 & 35 & 4.2 \\
\hline ZAGREB & $\mathrm{HR}$ & 45.80667 & 15.97 & 165 & -10.65 & 154 & 4.3 \\
\hline ZAGREB & $H R$ & 45.80667 & 15.97 & 165 & -8.73 & 29 & 4.3 \\
\hline ZAGREB & $H R$ & 45.80667 & 15.97 & 165 & -10.55 & 74 & 4.5 \\
\hline ZAGREB & $H R$ & 45.80667 & 15.97 & 165 & -11.53 & 53 & 5 \\
\hline ZAGREB & $\mathrm{HR}$ & 45.80667 & 15.97 & 165 & -12.59 & 70 & 5 \\
\hline ZAGREB & $H R$ & 45.80667 & 15.97 & 165 & -12.4 & 31 & \\
\hline ZAGREB & $H R$ & 45.80667 & 15.97 & 165 & -13.07 & 135 & 5.1 \\
\hline ZAGREB & $\mathrm{HR}$ & 45.80667 & 15.97 & 165 & -10.11 & 61 & 5.2 \\
\hline ZAGREB & $H R$ & 45.80667 & 15.97 & 165 & -10.02 & 26 & 5.4 \\
\hline ZAGREB & $H R$ & 45.80667 & 15.97 & 165 & -12.53 & 30 & 5.5 \\
\hline ZAGREB & $\mathrm{HR}$ & 45.80667 & 15.97 & 165 & -13.4 & 40 & 5.7 \\
\hline ZAGREB & $\mathrm{HR}$ & 45.80667 & 15.97 & 165 & -11.37 & 43 & 5.8 \\
\hline ZAGREB & $H R$ & 45.80667 & 15.97 & 165 & -11.47 & 147 & \\
\hline ZAGREB & $\mathrm{HR}$ & 45.80667 & 15.97 & 165 & -11.39 & 82 & 6.1 \\
\hline ZAGREB & $\mathrm{HR}$ & 45.80667 & 15.97 & 165 & -11.81 & 44 & 6.2 \\
\hline ZAGREB & $\mathrm{HR}$ & 45.80667 & 15.97 & 165 & -9.25 & 32 & 6.2 \\
\hline ZAGREB & $H R$ & 45.80667 & 15.97 & 165 & -14.49 & 49 & 6.4 \\
\hline ZAGREB & $\mathrm{HR}$ & 45.80667 & 15.97 & 165 & -11.1 & 70 & 6.5 \\
\hline ZAGREB & $H R$ & 45.80667 & 15.97 & 165 & -10.75 & 78 & 6.8 \\
\hline ZAGREB & $\mathrm{HR}$ & 45.80667 & 15.97 & 165 & -10.37 & 102 & 6.8 \\
\hline ZAGREB & $\mathrm{HR}$ & 45.80667 & 15.97 & 165 & -8.29 & 47 & 6.9 \\
\hline ZAGREB & $\mathrm{HR}$ & 45.80667 & 15.97 & 165 & -12.18 & 59 & 7 \\
\hline ZAGREB & $H R$ & 45.80667 & 15.97 & 165 & -9.65 & 11 & 7 \\
\hline ZAGREB & $H R$ & 45.80667 & 15.97 & 165 & -13.29 & 39 & 7.1 \\
\hline ZAGREB & $\mathrm{HR}$ & 45.80667 & 15.97 & 165 & -8.82 & 146 & 7.1 \\
\hline ZAGREB & $H R$ & 45.80667 & 15.97 & 165 & -9.5 & 70 & 7.1 \\
\hline ZAGREB & $H R$ & 45.80667 & 15.97 & 165 & -9.7 & 25 & 7.2 \\
\hline ZAGREB & $H R$ & 45.80667 & 15.97 & 165 & -10.85 & 112 & \\
\hline ZAGREB & $\mathrm{HR}$ & 45.80667 & 15.97 & 165 & -11.3 & 101 & 8.3 \\
\hline ZAGREB & $H R$ & 45.80667 & 15.97 & 165 & -10.89 & 74 & 8.6 \\
\hline ZAGREB & $\mathrm{HR}$ & 45.80667 & 15.97 & 165 & -10.45 & 28 & 8.6 \\
\hline ZAGREB & $\mathrm{HR}$ & 45.80667 & 15.97 & 165 & -11.67 & 84 & 8.7 \\
\hline ZAGREB & $H R$ & 45.80667 & 15.97 & 165 & -9.5 & 32 & 8.9 \\
\hline ZAGREB & $H R$ & 45.80667 & 15.97 & 165 & -9.08 & 49 & 9.4 \\
\hline ZAGREB & $\mathrm{HR}$ & 45.80667 & 15.97 & 165 & -12.26 & 69 & 10.1 \\
\hline ZAGREB & $\mathrm{HR}$ & 45.80667 & 15.97 & 165 & -10.2 & 110 & 10.1 \\
\hline ZAGREB & $H R$ & 45.80667 & 15.97 & 165 & -8.44 & 30 & 10.2 \\
\hline ZAGREB & $\mathrm{HR}$ & 45.80667 & 15.97 & 165 & -9.7 & 88 & 10.2 \\
\hline ZAGREB & $\mathrm{HR}$ & 45.80667 & 15.97 & 165 & -8.95 & 44 & 10.5 \\
\hline ZAGREB & $H R$ & 45.80667 & 15.97 & 165 & -7.62 & 162 & 10.6 \\
\hline ZAGREB & $\mathrm{HR}$ & 45.80667 & 15.97 & 165 & -7.52 & 54 & 11 \\
\hline ZAGREB & $\mathrm{HR}$ & 45.80667 & 15.97 & 165 & -9.28 & 194 & 11.2 \\
\hline ZAGREB & $H R$ & 45.80667 & 15.97 & 165 & -11.09 & 44 & \\
\hline ZAGREB & $\mathrm{HR}$ & 45.80667 & 15.97 & 165 & -8.09 & 68 & 11.3 \\
\hline ZAGREB & $\mathrm{HR}$ & 45.80667 & 15.97 & 165 & -8.2 & 54 & 11.3 \\
\hline ZAGREB & $\mathrm{HR}$ & 45.80667 & 15.97 & 165 & -6.67 & 4 & \\
\hline ZAGREB & $H R$ & 45.80667 & 15.97 & 165 & -7.37 & 43 & \\
\hline
\end{tabular}




\begin{tabular}{|c|c|c|c|c|c|c|c|}
\hline ZAGREB & $H R$ & 45.80667 & 15.97 & 165 & -8.33 & 99 & 11.5 \\
\hline ZAGREB & $\mathrm{HR}$ & 45.80667 & 15.97 & 165 & -7.8 & 50 & 11.5 \\
\hline ZAGREB & $H R$ & 45.80667 & 15.97 & 165 & -11.09 & 96 & 11.6 \\
\hline ZAGREB & $H R$ & 45.80667 & 15.97 & 165 & -8.04 & 62 & 11.7 \\
\hline ZAGREB & $H R$ & 45.80667 & 15.97 & 165 & -9.2 & 87 & 12 \\
\hline ZAGREB & $H R$ & 45.80667 & 15.97 & 165 & -7.2 & 21 & 12.1 \\
\hline ZAGREB & $\mathrm{HR}$ & 45.80667 & 15.97 & 165 & -6.6 & 104 & 12.1 \\
\hline ZAGREB & $H R$ & 45.80667 & 15.97 & 165 & -8.06 & 17 & 12.3 \\
\hline ZAGREB & $H R$ & 45.80667 & 15.97 & 165 & -9.37 & 126 & 12.5 \\
\hline ZAGREB & $H R$ & 45.80667 & 15.97 & 165 & -7.35 & 90 & 12.5 \\
\hline ZAGREB & $H R$ & 45.80667 & 15.97 & 165 & -9.72 & 42 & 12.6 \\
\hline ZAGREB & $H R$ & 45.80667 & 15.97 & 165 & -9.17 & 71 & 12.7 \\
\hline ZAGREB & $H R$ & 45.80667 & 15.97 & 165 & -8.11 & 70 & 12.8 \\
\hline ZAGREB & $H R$ & 45.80667 & 15.97 & 165 & -9.29 & 58 & 12.8 \\
\hline ZAGREB & $H R$ & 45.80667 & 15.97 & 165 & -8.52 & 65 & 12.8 \\
\hline ZAGREB & $H R$ & 45.80667 & 15.97 & 165 & -4.38 & 36 & 12.8 \\
\hline ZAGREB & $H R$ & 45.80667 & 15.97 & 165 & -5.75 & 50 & 12.9 \\
\hline ZAGREB & $H R$ & 45.80667 & 15.97 & 165 & -4.9 & 132 & 12.9 \\
\hline ZAGREB & $H R$ & 45.80667 & 15.97 & 165 & -10 & 70 & 13 \\
\hline ZAGREB & $H R$ & 45.80667 & 15.97 & 165 & -9.1 & 31 & 13 \\
\hline ZAGREB & $H R$ & 45.80667 & 15.97 & 165 & -9.89 & 122 & 13.3 \\
\hline ZAGREB & $H R$ & 45.80667 & 15.97 & 165 & -7.87 & 64 & 13.5 \\
\hline ZAGREB & $H R$ & 45.80667 & 15.97 & 165 & -4.44 & 17 & 14.1 \\
\hline ZAGREB & $H R$ & 45.80667 & 15.97 & 165 & -7.67 & 141 & 14.5 \\
\hline ZAGREB & $H R$ & 45.80667 & 15.97 & 165 & -5.82 & 90 & 14.8 \\
\hline ZAGREB & $H R$ & 45.80667 & 15.97 & 165 & -7.2 & 154 & 15.5 \\
\hline ZAGREB & $H R$ & 45.80667 & 15.97 & 165 & -6 & 106 & 15.7 \\
\hline ZAGREB & $H R$ & 45.80667 & 15.97 & 165 & -7.51 & 105 & 15.8 \\
\hline ZAGREB & $H R$ & 45.80667 & 15.97 & 165 & -8.19 & 80 & 15.9 \\
\hline ZAGREB & $H R$ & 45.80667 & 15.97 & 165 & -7.42 & 132 & 16 \\
\hline ZAGREB & $\mathrm{HR}$ & 45.80667 & 15.97 & 165 & -6.5 & 98 & 16.1 \\
\hline ZAGREB & $H R$ & 45.80667 & 15.97 & 165 & -5.91 & 49 & 16.2 \\
\hline ZAGREB & $H R$ & 45.80667 & 15.97 & 165 & -7.8 & 152 & 16.5 \\
\hline ZAGREB & $\mathrm{HR}$ & 45.80667 & 15.97 & 165 & -7.24 & 117 & 16.8 \\
\hline ZAGREB & $H R$ & 45.80667 & 15.97 & 165 & -6.38 & 80 & 16.9 \\
\hline ZAGREB & $H R$ & 45.80667 & 15.97 & 165 & -5.3 & 68 & 16.9 \\
\hline ZAGREB & $H R$ & 45.80667 & 15.97 & 165 & -6.04 & 52 & 17 \\
\hline ZAGREB & $H R$ & 45.80667 & 15.97 & 165 & -8.63 & 78 & 17.2 \\
\hline ZAGREB & $H R$ & 45.80667 & 15.97 & 165 & -7.02 & 96 & 17.2 \\
\hline ZAGREB & $H R$ & 45.80667 & 15.97 & 165 & -7.26 & 130 & 17.3 \\
\hline ZAGREB & $\mathrm{HR}$ & 45.80667 & 15.97 & 165 & -6.04 & 21 & 17.3 \\
\hline ZAGREB & $H R$ & 45.80667 & 15.97 & 165 & -7.53 & 107 & 17.5 \\
\hline ZAGREB & $H R$ & 45.80667 & 15.97 & 165 & -6.92 & 162 & 17.5 \\
\hline ZAGREB & $H R$ & 45.80667 & 15.97 & 165 & -6.12 & 122 & 17.7 \\
\hline ZAGREB & $H R$ & 45.80667 & 15.97 & 165 & -7.34 & 84 & 17.8 \\
\hline ZAGREB & $H R$ & 45.80667 & 15.97 & 165 & -6.22 & 38 & 17.8 \\
\hline ZAGREB & $H R$ & 45.80667 & 15.97 & 165 & -2.11 & 10 & 17.9 \\
\hline ZAGREB & $H R$ & 45.80667 & 15.97 & 165 & -5.73 & 66 & 18 \\
\hline ZAGREB & $H R$ & 45.80667 & 15.97 & 165 & -6.43 & 194 & 18.3 \\
\hline ZAGREB & $H R$ & 45.80667 & 15.97 & 165 & -5.9 & 72 & 18.4 \\
\hline
\end{tabular}




\begin{tabular}{|c|c|c|c|c|c|c|c|}
\hline ZAGREB & $\mathrm{HR}$ & 45.80667 & 15.97 & 165 & -6.51 & 63 & 18.4 \\
\hline ZAGREB & $H R$ & 45.80667 & 15.97 & 165 & -9.5 & 92 & 18.5 \\
\hline ZAGREB & $\mathrm{HR}$ & 45.80667 & 15.97 & 165 & -6.54 & 42 & 18.7 \\
\hline ZAGREB & $\mathrm{HR}$ & 45.80667 & 15.97 & 165 & -6.74 & 67 & 10 \\
\hline ZAGREB & $\mathrm{HR}$ & 45.80667 & 15.97 & 165 & -6.45 & 71 & \\
\hline ZAGREB & $\mathrm{HR}$ & 45.80667 & 15.97 & 165 & -4.76 & 87 & \\
\hline ZAGREB & $\mathrm{HR}$ & 45.80667 & 15.97 & 165 & -8.21 & 93 & \\
\hline ZAGREB & $H R$ & 45.80667 & 15.97 & 165 & -4.5 & 32 & 15 \\
\hline ZAGREB & $\mathrm{HR}$ & 45.80667 & 15.97 & 165 & -5.25 & 67 & \\
\hline ZAGREB & $\mathrm{HR}$ & 45.80667 & 15.97 & 165 & -6.61 & 122 & 19.5 \\
\hline ZAGREB & $\mathrm{HR}$ & 45.80667 & 15.97 & 165 & -8.36 & 68 & \\
\hline ZAGREB & $\mathrm{HR}$ & 45.80667 & 15.97 & 165 & -8.8 & 131 & 19 \\
\hline ZAGREB & $\mathrm{HR}$ & 45.80667 & 15.97 & 165 & -8.23 & 83 & \\
\hline ZAGREB & $\mathrm{HR}$ & 45.80667 & 15.97 & 165 & -4.74 & 47 & \\
\hline ZAGREB & $\mathrm{HR}$ & 45.80667 & 15.97 & 165 & -5.84 & 30 & \\
\hline ZAGREB & $\mathrm{HR}$ & 45.80667 & 15.97 & 165 & -4.32 & 95 & \\
\hline ZAGREB & $\mathrm{HR}$ & 45.80667 & 15.97 & 165 & -8.19 & 108 & 20 \\
\hline ZAGREB & $\mathrm{HR}$ & 45.80667 & 15.97 & 165 & -5.4 & 134 & 20.2 \\
\hline ZAGREB & $\mathrm{HR}$ & 45.80667 & 15.97 & 165 & -7.8 & 154 & 20.4 \\
\hline ZAGREB & $\mathrm{HR}$ & 45.80667 & 15.97 & 165 & -6.3 & 81 & \\
\hline ZAGREB & $\mathrm{HR}$ & 45.80667 & 15.97 & 165 & -3.71 & 103 & \\
\hline ZAGREB & $\mathrm{HR}$ & 45.80667 & 15.97 & 165 & -8.33 & 96 & \\
\hline ZAGREB & $\mathrm{HR}$ & 45.80667 & 15.97 & 165 & -5.3 & 80 & \\
\hline ZAGREB & $\mathrm{HR}$ & 45.80667 & 15.97 & 165 & -6.79 & 110 & 20 \\
\hline ZAGREB & $\mathrm{HR}$ & 45.80667 & 15.97 & 165 & -7.63 & 49 & \\
\hline ZAGREB & $\mathrm{HR}$ & 45.80667 & 15.97 & 165 & -6.54 & 260 & \\
\hline ZAGREB & $\mathrm{HR}$ & 45.80667 & 15.97 & 165 & -4.31 & 30 & \\
\hline ZAGREB & $\mathrm{HR}$ & 45.80667 & 15.97 & 165 & -6.24 & 88 & \\
\hline ZAGREB & $H R$ & 45.80667 & 15.97 & 165 & -7.74 & 96 & \\
\hline ZAGREB & $\mathrm{HR}$ & 45.80667 & 15.97 & 165 & -6.44 & 82 & \\
\hline ZAGREB & $\mathrm{HR}$ & 45.80667 & 15.97 & 165 & -3.93 & 46 & \\
\hline ZAGREB & $\mathrm{HR}$ & 45.80667 & 15.97 & 165 & -5 & 53 & \\
\hline ZAGREB & $\mathrm{HR}$ & 45.80667 & 15.97 & 165 & -6.69 & 81 & \\
\hline ZAGREB & $\mathrm{HR}$ & 45.80667 & 15.97 & 165 & -6.32 & 134 & \\
\hline ZAGREB & $\mathrm{HR}$ & 45.80667 & 15.97 & 165 & -5.93 & 31 & \\
\hline ZAGREB & $H R$ & 45.80667 & 15.97 & 165 & -5.94 & 85 & \\
\hline ZAGREB & $\mathrm{HR}$ & 45.80667 & 15.97 & 165 & -10.94 & 54 & \\
\hline ZAGREB & $\mathrm{HR}$ & 45.80667 & 15.97 & 165 & -4.4 & 25 & 22.2 \\
\hline ZAGREB & $H R$ & 45.80667 & 15.97 & 165 & -5.9 & 111 & \\
\hline ZAGREB & $\mathrm{HR}$ & 45.80667 & 15.97 & 165 & -2.54 & 58 & \\
\hline ZAGREB & $\mathrm{HR}$ & 45.80667 & 15.97 & 165 & -5.79 & 82 & \\
\hline ZAGREB & $\mathrm{HR}$ & 45.80667 & 15.97 & 165 & -5.6 & 179 & \\
\hline ZAGREB & $\mathrm{HR}$ & 45.80667 & 15.97 & 165 & -6.95 & 68 & \\
\hline ZAGREB & $\mathrm{HR}$ & 45.80667 & 15.97 & 165 & -5.49 & 31 & \\
\hline ZAGREB & $\mathrm{HR}$ & 45.80667 & 15.97 & 165 & -3.92 & 26 & \\
\hline ZAGREB & $\mathrm{HR}$ & 45.80667 & 15.97 & 165 & -5.7 & 91 & \\
\hline ZAGREB & $\mathrm{HR}$ & 45.80667 & 15.97 & 165 & -4.7 & 104 & \\
\hline \multicolumn{2}{|c|}{ ZAGREB-GR HR } & 45.81667 & 15.98333 & 157 & -15.64 & 46 & \\
\hline \multicolumn{2}{|c|}{ ZAGREB-GR HR } & 45.81667 & 15.98333 & 157 & -11.6 & 26.2 & 0. \\
\hline \multicolumn{2}{|c|}{ ZAGREB-GR HR } & 45.81667 & 15.98333 & 157 & -12.13 & 64 & \\
\hline
\end{tabular}




\begin{tabular}{|c|c|c|c|c|c|c|}
\hline ZAGREB-GR HR & 45.81667 & 15.98333 & 157 & -15.25 & 18.8 & -0.2 \\
\hline ZAGREB-GR HR & 45.81667 & 15.98333 & 157 & -9.54 & 80 & -0.1 \\
\hline ZAGREB-GR HR & 45.81667 & 15.98333 & 157 & -15.5 & 30.5 & -0.1 \\
\hline ZAGREB-GR HR & 45.81667 & 15.98333 & 157 & -14.48 & 37 & 0.3 \\
\hline ZAGREB-GR HR & 45.81667 & 15.98333 & 157 & -16.5 & 72.1 & 0.5 \\
\hline ZAGREB-GR HR & 45.81667 & 15.98333 & 157 & -13.98 & 44 & 1.6 \\
\hline ZAGREB-GR HR & 45.81667 & 15.98333 & 157 & -12.9 & 24.9 & 2.2 \\
\hline ZAGREB-GR HR & 45.81667 & 15.98333 & 157 & -12.64 & 102 & 2.6 \\
\hline ZAGREB-GR HR & 45.81667 & 15.98333 & 157 & -10.8 & 71 & 2.7 \\
\hline ZAGREB-GR HR & 45.81667 & 15.98333 & 157 & -14.86 & 72 & 2.9 \\
\hline ZAGREB-GR HR & 45.81667 & 15.98333 & 157 & -9.37 & 28.6 & \\
\hline ZAGREB-GR HR & 45.81667 & 15.98333 & 157 & -13.46 & 84 & 3.9 \\
\hline ZAGREB-GR HR & 45.81667 & 15.98333 & 157 & -8.34 & 11 & 4.5 \\
\hline ZAGREB-GR HR & 45.81667 & 15.98333 & 157 & -11.13 & 63 & 4.5 \\
\hline ZAGREB-GR HR & 45.81667 & 15.98333 & 157 & -15.35 & 76 & 4.6 \\
\hline ZAGREB-GR HR & 45.81667 & 15.98333 & 157 & -8.28 & 83.3 & 4.6 \\
\hline ZAGREB-GR HR & 45.81667 & 15.98333 & 157 & -11.4 & 94.5 & 4.7 \\
\hline ZAGREB-GR HR & 45.81667 & 15.98333 & 157 & -14.39 & 17 & 5.1 \\
\hline ZAGREB-GR HR & 45.81667 & 15.98333 & 157 & -6.38 & 28 & 5.1 \\
\hline ZAGREB-GR HR & 45.81667 & 15.98333 & 157 & -10.94 & 15.3 & 5.9 \\
\hline ZAGREB-GR HR & 45.81667 & 15.98333 & 157 & -8.12 & 59 & 6.4 \\
\hline ZAGREB-GR HR & 45.81667 & 15.98333 & 157 & -7.22 & 21.9 & 6.5 \\
\hline ZAGREB-GR HR & 45.81667 & 15.98333 & 157 & -10.33 & 103 & 6.6 \\
\hline ZAGREB-GR HR & 45.81667 & 15.98333 & 157 & -9.5 & 47.3 & 7.6 \\
\hline ZAGREB-GR HR & 45.81667 & 15.98333 & 157 & -9.72 & 32 & 8.1 \\
\hline ZAGREB-GR HR & 45.81667 & 15.98333 & 157 & -5.46 & 51.3 & 8.9 \\
\hline ZAGREB-GR HR & 45.81667 & 15.98333 & 157 & -14.41 & 114 & \\
\hline ZAGREB-GR HR & 45.81667 & 15.98333 & 157 & -10.47 & 56 & 9.2 \\
\hline ZAGREB-GR HR & 45.81667 & 15.98333 & 157 & -6.65 & 54.4 & 9.4 \\
\hline ZAGREB-GR HR & 45.81667 & 15.98333 & 157 & -8.66 & 33 & 9.5 \\
\hline ZAGREB-GR HR & 45.81667 & 15.98333 & 157 & -9.48 & 103.2 & 10.1 \\
\hline ZAGREB-GR HR & 45.81667 & 15.98333 & 157 & -8.03 & 49 & 10.3 \\
\hline ZAGREB-GR HR & 45.81667 & 15.98333 & 157 & -8.9 & 35.8 & 10.4 \\
\hline ZAGREB-GR HR & 45.81667 & 15.98333 & 157 & -6.83 & 112.5 & 10.5 \\
\hline ZAGREB-GR HR & 45.81667 & 15.98333 & 157 & -9.9 & 76 & 10.8 \\
\hline ZAGREB-GR HR & 45.81667 & 15.98333 & 157 & -9.21 & 100.8 & 10.9 \\
\hline ZAGREB-GR HR & 45.81667 & 15.98333 & 157 & -9.5 & 156.9 & 11.4 \\
\hline ZAGREB-GR HR & 45.81667 & 15.98333 & 157 & -7.67 & 83.1 & 11.8 \\
\hline ZAGREB-GR HR & 45.81667 & 15.98333 & 157 & -3.29 & 91 & 12 \\
\hline ZAGREB-GR HR & 45.81667 & 15.98333 & 157 & -8.3 & 108 & 12.3 \\
\hline ZAGREB-GR HR & 45.81667 & 15.98333 & 157 & -6.3 & 76 & 12.5 \\
\hline ZAGREB-GR HR & 45.81667 & 15.98333 & 157 & -7.23 & 128 & 12. \\
\hline ZAGREB-GR HR & 45.81667 & 15.98333 & 157 & -6.03 & 108 & 13 \\
\hline ZAGREB-GR HR & 45.81667 & 15.98333 & 157 & -6.94 & 58 & 13.4 \\
\hline ZAGREB-GR HR & 45.81667 & 15.98333 & 157 & -7.87 & 74 & 13 \\
\hline ZAGREB-GR HR & 45.81667 & 15.98333 & 157 & -10.16 & 164 & 13.8 \\
\hline ZAGREB-GR HR & 45.81667 & 15.98333 & 157 & -5.82 & 91.9 & 14. \\
\hline ZAGREB-GR HR & 45.81667 & 15.98333 & 157 & -9.6 & 177.3 & \\
\hline ZAGREB-GR HR & 45.81667 & 15.98333 & 157 & -6.64 & 59.6 & 15.4 \\
\hline GREB-GR HR & 81667 & .98333 & 157 & -3.7 & 9.2 & \\
\hline
\end{tabular}




\begin{tabular}{|c|c|c|c|c|c|c|}
\hline ZAGREB-GR HR & 45.81667 & 15.98333 & 157 & -8.6 & 89 & 16.1 \\
\hline ZAGREB-GR HR & 45.81667 & 15.98333 & 157 & -8.61 & 181 & 16.5 \\
\hline ZAGREB-GR HR & 45.81667 & 15.98333 & 157 & -7.4 & 106.6 & 17 \\
\hline ZAGREB-GR HR & 45.81667 & 15.98333 & 157 & -7.06 & 146 & 17.4 \\
\hline ZAGREB-GR HR & 45.81667 & 15.98333 & 157 & -4.14 & 71 & 17.5 \\
\hline ZAGREB-GR HR & 45.81667 & 15.98333 & 157 & -7.82 & 70 & 17.8 \\
\hline ZAGREB-GR HR & 45.81667 & 15.98333 & 157 & -8.2 & 26 & 17.8 \\
\hline ZAGREB-GR HR & 45.81667 & 15.98333 & 157 & -6.92 & 82.1 & 17.8 \\
\hline ZAGREB-GR HR & 45.81667 & 15.98333 & 157 & -2.28 & 45.5 & 18.5 \\
\hline ZAGREB-GR HR & 45.81667 & 15.98333 & 157 & -7.08 & 56.1 & 18.7 \\
\hline ZAGREB-GR HR & 45.81667 & 15.98333 & 157 & -5.3 & 85.3 & 18.9 \\
\hline ZAGREB-GR HR & 45.81667 & 15.98333 & 157 & -3.89 & 121.7 & 19.1 \\
\hline ZAGREB-GR HR & 45.81667 & 15.98333 & 157 & -5.13 & 65 & 19.5 \\
\hline ZAGREB-GR HR & 45.81667 & 15.98333 & 157 & -3.69 & 59 & 20.1 \\
\hline ZAGREB-GR HR & 45.81667 & 15.98333 & 157 & -5.84 & 85 & 20.3 \\
\hline ZAGREB-GR HR & 45.81667 & 15.98333 & 157 & -5.24 & 19.8 & 20.4 \\
\hline ZAGREB-GR HR & 45.81667 & 15.98333 & 157 & -6.21 & 65 & 20.5 \\
\hline ZAGREB-GR HR & 45.81667 & 15.98333 & 157 & -5.74 & 133 & 20.8 \\
\hline ZAGREB-GR HR & 45.81667 & 15.98333 & 157 & -7.21 & 59 & 21 \\
\hline ZAGREB-GR HR & 45.81667 & 15.98333 & 157 & -0.46 & 124 & 21.2 \\
\hline ZAGREB-GR HR & 45.81667 & 15.98333 & 157 & -6.45 & 70 & 21.3 \\
\hline ZAGREB-GR HR & 45.81667 & 15.98333 & 157 & -5.55 & 81 & 21.4 \\
\hline ZAGREB-GR HR & 45.81667 & 15.98333 & 157 & -9 & 84.2 & 21.5 \\
\hline ZAGREB-GR HR & 45.81667 & 15.98333 & 157 & -7.16 & 62 & 21.6 \\
\hline ZAGREB-GR HR & 45.81667 & 15.98333 & 157 & -8.5 & 151 & 21.6 \\
\hline ZAGREB-GR HR & 45.81667 & 15.98333 & 157 & -4.1 & 70.2 & 21.9 \\
\hline ZAGREB-GR HR & 45.81667 & 15.98333 & 157 & -5.59 & 147 & 22.3 \\
\hline ZAGREB-GR HR & 45.81667 & 15.98333 & 157 & -3.71 & 44.2 & 22.3 \\
\hline ZAGREB-GR HR & 45.81667 & 15.98333 & 157 & -6.46 & 144 & 22.4 \\
\hline ZAGREB-GR HR & 45.81667 & 15.98333 & 157 & -7.06 & 94 & 22.4 \\
\hline ZAGREB-GR HR & 45.81667 & 15.98333 & 157 & -6.4 & 148.2 & 22.5 \\
\hline ZAGREB-GR HR & 45.81667 & 15.98333 & 157 & -5.06 & 54.6 & 22.9 \\
\hline ZAGREB-GR HR & 45.81667 & 15.98333 & 157 & -6.49 & 20.4 & 23.6 \\
\hline ZAGREB-GR HR & 45.81667 & 15.98333 & 157 & -3.75 & 78.6 & 23.6 \\
\hline ZAGREB-GR HR & 45.81667 & 15.98333 & 157 & -3.5 & 75.2 & 24.5 \\
\hline ZAGREB-GR HR & 45.81667 & 15.98333 & 157 & -6.07 & 17.4 & 25.8 \\
\hline DEBRECEN HU & 47.47051 & 21.49042 & 110 & -13.06 & 0.3 & -10 \\
\hline DEBRECEN HU & 47.47051 & 21.49042 & 110 & -19.62 & 4.6 & -9.6 \\
\hline DEBRECEN HU & 47.47051 & 21.49042 & 110 & -3.65 & 4.6 & -8.4 \\
\hline DEBRECEN HU & 47.47051 & 21.49042 & 110 & -3.72 & 0.4 & -8.1 \\
\hline DEBRECEN HU & 47.47051 & 21.49042 & 110 & -10.47 & 1.3 & -7.9 \\
\hline DEBRECEN HU & 47.47051 & 21.49042 & 110 & -16.52 & 0.5 & -7.8 \\
\hline DEBRECEN HU & 47.47051 & 21.49042 & 110 & -16 & 3.8 & -7.6 \\
\hline DEBRECEN HU & 47.47051 & 21.49042 & 110 & -11.4 & 2.8 & -6.7 \\
\hline DEBRECEN HU & 47.47051 & 21.49042 & 110 & -14.8 & 0.8 & -6.6 \\
\hline DEBRECEN HU & 47.47051 & 21.49042 & 110 & -16.86 & 1.4 & -6.6 \\
\hline DEBRECEN HU & 47.47051 & 21.49042 & 110 & -20.72 & 1.8 & -6.4 \\
\hline DEBRECEN HU & 47.47051 & 21.49042 & 110 & -17 & 14 & -6.2 \\
\hline DEBRECEN HU & 47.47051 & 21.49042 & 110 & -9.52 & 7.1 & -6.1 \\
\hline DEBRECEN HU & 47.47051 & 21.49042 & 110 & -21.25 & 1.1 & \\
\hline
\end{tabular}




\begin{tabular}{|c|c|c|c|c|c|c|}
\hline DEBRECEN HU & 47.47051 & 21.49042 & 110 & -3.44 & 6.3 & -5.9 \\
\hline DEBRECEN HU & 47.47051 & 21.49042 & 110 & -15.1 & 12.5 & -5.5 \\
\hline DEBRECEN HU & 47.47051 & 21.49042 & 110 & -7.78 & 3.3 & -5.4 \\
\hline DEBRECEN HU & 47.47051 & 21.49042 & 110 & -11.95 & 1.4 & -5.4 \\
\hline DEBRECEN HU & 47.47051 & 21.49042 & 110 & -19.04 & 0.3 & -5.2 \\
\hline DEBRECEN HU & 47.47051 & 21.49042 & 110 & -10.74 & 0.7 & -5.2 \\
\hline DEBRECEN HU & 47.47051 & 21.49042 & 110 & -17.76 & 1.1 & -5.2 \\
\hline DEBRECEN HU & 47.47051 & 21.49042 & 110 & -19.63 & 5.4 & -5.2 \\
\hline DEBRECEN HU & 47.47051 & 21.49042 & 110 & -20.71 & 9.5 & -4.6 \\
\hline DEBRECEN HU & 47.47051 & 21.49042 & 110 & -6.57 & 0.7 & -4.4 \\
\hline DEBRECEN HU & 47.47051 & 21.49042 & 110 & -4.42 & 3.2 & -4.2 \\
\hline DEBRECEN HU & 47.47051 & 21.49042 & 110 & -10.86 & 13 & -4.2 \\
\hline DEBRECEN HU & 47.47051 & 21.49042 & 110 & -19.4 & 6.8 & -3.9 \\
\hline DEBRECEN HU & 47.47051 & 21.49042 & 110 & -16.8 & 3.1 & -3.8 \\
\hline DEBRECEN HU & 47.47051 & 21.49042 & 110 & -18.3 & 5.2 & -3.6 \\
\hline DEBRECEN HU & 47.47051 & 21.49042 & 110 & -10.47 & 1.1 & -3.5 \\
\hline DEBRECEN HU & 47.47051 & 21.49042 & 110 & -12.19 & 0.1 & -3.5 \\
\hline DEBRECEN HU & 47.47051 & 21.49042 & 110 & -8.8 & 2.7 & -3.4 \\
\hline DEBRECEN HU & 47.47051 & 21.49042 & 110 & -12.41 & 0.6 & -3.2 \\
\hline DEBRECEN HU & 47.47051 & 21.49042 & 110 & -19.28 & 14.6 & -3.1 \\
\hline DEBRECEN HU & 47.47051 & 21.49042 & 110 & -11.8 & 0.3 & -3.1 \\
\hline DEBRECEN HU & 47.47051 & 21.49042 & 110 & -5 & 0.3 & -3 \\
\hline DEBRECEN HU & 47.47051 & 21.49042 & 110 & -16.44 & 3.8 & -3 \\
\hline DEBRECEN HU & 47.47051 & 21.49042 & 110 & -11.62 & 0.6 & -2.7 \\
\hline DEBRECEN HU & 47.47051 & 21.49042 & 110 & -9.97 & 0.1 & -2.5 \\
\hline DEBRECEN HU & 47.47051 & 21.49042 & 110 & -20.95 & 0.4 & -2.5 \\
\hline DEBRECEN HU & 47.47051 & 21.49042 & 110 & -12.63 & 3.2 & -2.2 \\
\hline DEBRECEN HU & 47.47051 & 21.49042 & 110 & -12.45 & 1.6 & -2.2 \\
\hline DEBRECEN HU & 47.47051 & 21.49042 & 110 & -13.84 & 7.1 & -2 \\
\hline DEBRECEN HU & 47.47051 & 21.49042 & 110 & -18.9 & 1.7 & -1.6 \\
\hline DEBRECEN HU & 47.47051 & 21.49042 & 110 & -12.9 & 0.2 & -1.5 \\
\hline DEBRECEN HU & 47.47051 & 21.49042 & 110 & -6.93 & 0.1 & -1.4 \\
\hline DEBRECEN HU & 47.47051 & 21.49042 & 110 & -9.41 & 1.5 & -1.3 \\
\hline DEBRECEN HU & 47.47051 & 21.49042 & 110 & -22.13 & 9.8 & -1.3 \\
\hline DEBRECEN HU & 47.47051 & 21.49042 & 110 & -17.2 & 11.6 & -1.2 \\
\hline DEBRECEN HU & 47.47051 & 21.49042 & 110 & -21.45 & 2.5 & -1.2 \\
\hline DEBRECEN HU & 47.47051 & 21.49042 & 110 & -11.45 & 2.7 & -1.1 \\
\hline DEBRECEN HU & 47.47051 & 21.49042 & 110 & -16.4 & 15.6 & -1 \\
\hline DEBRECEN HU & 47.47051 & 21.49042 & 110 & -10.97 & 7.7 & -1 \\
\hline DEBRECEN HU & 47.47051 & 21.49042 & 110 & -8.25 & 1.6 & -0.9 \\
\hline DEBRECEN HU & 47.47051 & 21.49042 & 110 & -3.8 & 3.3 & -0.8 \\
\hline DEBRECEN HU & 47.47051 & 21.49042 & 110 & -8.28 & 6.9 & -0.8 \\
\hline DEBRECEN HU & 47.47051 & 21.49042 & 110 & -12.11 & 2.6 & -0.8 \\
\hline DEBRECEN HU & 47.47051 & 21.49042 & 110 & -18.1 & 4 & -0.8 \\
\hline DEBRECEN HU & 47.47051 & 21.49042 & 110 & -9.2 & 2.9 & -0.7 \\
\hline DEBRECEN HU & 47.47051 & 21.49042 & 110 & -7.77 & 0.9 & -0.7 \\
\hline DEBRECEN HU & 47.47051 & 21.49042 & 110 & -6.27 & 0.2 & -0.5 \\
\hline DEBRECEN HU & 47.47051 & 21.49042 & 110 & -11.55 & 1 & -0.4 \\
\hline DEBRECEN HU & 47.47051 & 21.49042 & 110 & -11.6 & 1 & -0.4 \\
\hline DEBRECEN HU & 47.47051 & 21.49042 & 110 & -11.05 & 13.3 & \\
\hline
\end{tabular}




\begin{tabular}{|c|c|c|c|c|c|c|}
\hline DEBRECEN HU & 47.47051 & 21.49042 & 110 & -14.06 & 20.4 & -0.3 \\
\hline DEBRECEN HU & 47.47051 & 21.49042 & 110 & -18.7 & 1.4 & -0.3 \\
\hline DEBRECEN HU & 47.47051 & 21.49042 & 110 & -16.07 & 3.9 & -0.2 \\
\hline DEBRECEN HU & 47.47051 & 21.49042 & 110 & -8.92 & 0.8 & -0.1 \\
\hline DEBRECEN HU & 47.47051 & 21.49042 & 110 & -16.3 & 7.7 & -0.1 \\
\hline DEBRECEN HU & 47.47051 & 21.49042 & 110 & -9.83 & 10.4 & -0.1 \\
\hline DEBRECEN HU & 47.47051 & 21.49042 & 110 & -13.5 & 4 & 0.1 \\
\hline DEBRECEN HU & 47.47051 & 21.49042 & 110 & -9.1 & 24 & 0.2 \\
\hline DEBRECEN HU & 47.47051 & 21.49042 & 110 & -15.9 & 2.7 & 0.2 \\
\hline DEBRECEN HU & 47.47051 & 21.49042 & 110 & -10.01 & 34.2 & 0.4 \\
\hline DEBRECEN HU & 47.47051 & 21.49042 & 110 & -9.3 & 3 & 0.4 \\
\hline DEBRECEN HU & 47.47051 & 21.49042 & 110 & -16.2 & 3.2 & 0.4 \\
\hline DEBRECEN HU & 47.47051 & 21.49042 & 110 & -9.7 & 2.7 & 0.4 \\
\hline DEBRECEN HU & 47.47051 & 21.49042 & 110 & -19.48 & 3.2 & 0.4 \\
\hline DEBRECEN HU & 47.47051 & 21.49042 & 110 & -13 & 0.2 & 0.5 \\
\hline DEBRECEN HU & 47.47051 & 21.49042 & 110 & -16.7 & 11.7 & 0.5 \\
\hline DEBRECEN HU & 47.47051 & 21.49042 & 110 & -11.42 & 0.1 & 0.6 \\
\hline DEBRECEN HU & 47.47051 & 21.49042 & 110 & -9.93 & 1 & 0.6 \\
\hline DEBRECEN HU & 47.47051 & 21.49042 & 110 & -11.3 & 0.1 & 0.6 \\
\hline DEBRECEN HU & 47.47051 & 21.49042 & 110 & -15.08 & 12.4 & 0.6 \\
\hline DEBRECEN HU & 47.47051 & 21.49042 & 110 & -7.94 & 17.6 & 0.7 \\
\hline DEBRECEN HU & 47.47051 & 21.49042 & 110 & -12.42 & 8.5 & 0.7 \\
\hline DEBRECEN HU & 47.47051 & 21.49042 & 110 & -12.05 & 1.6 & 0.7 \\
\hline DEBRECEN HU & 47.47051 & 21.49042 & 110 & -8.12 & 2 & 0.9 \\
\hline DEBRECEN HU & 47.47051 & 21.49042 & 110 & -11.35 & 11 & 0.9 \\
\hline DEBRECEN HU & 47.47051 & 21.49042 & 110 & -9.49 & 0.2 & 1 \\
\hline DEBRECEN HU & 47.47051 & 21.49042 & 110 & -11.18 & 6.9 & 1 \\
\hline DEBRECEN HU & 47.47051 & 21.49042 & 110 & -12.46 & 31.8 & 1.2 \\
\hline DEBRECEN HU & 47.47051 & 21.49042 & 110 & -13.42 & 11.1 & 1.2 \\
\hline DEBRECEN HU & 47.47051 & 21.49042 & 110 & -17.51 & 2.9 & 1.3 \\
\hline DEBRECEN HU & 47.47051 & 21.49042 & 110 & -16.48 & 6.9 & 1.4 \\
\hline DEBRECEN HU & 47.47051 & 21.49042 & 110 & -12.91 & 20.2 & 1.5 \\
\hline DEBRECEN HU & 47.47051 & 21.49042 & 110 & -11.34 & 27.8 & 1.5 \\
\hline DEBRECEN HU & 47.47051 & 21.49042 & 110 & -18.44 & 2.7 & 1.5 \\
\hline DEBRECEN HU & 47.47051 & 21.49042 & 110 & -16.07 & 3.7 & 1.5 \\
\hline DEBRECEN HU & 47.47051 & 21.49042 & 110 & -11.72 & 3 & 1.6 \\
\hline DEBRECEN HU & 47.47051 & 21.49042 & 110 & -13.67 & 3.5 & 1.6 \\
\hline DEBRECEN HU & 47.47051 & 21.49042 & 110 & -0.56 & 0.1 & 1.6 \\
\hline DEBRECEN HU & 47.47051 & 21.49042 & 110 & -17.1 & 1.6 & 1.7 \\
\hline DEBRECEN HU & 47.47051 & 21.49042 & 110 & -13.1 & 11.6 & 1.7 \\
\hline DEBRECEN HU & 47.47051 & 21.49042 & 110 & -9.2 & 0.2 & 1.8 \\
\hline DEBRECEN HU & 47.47051 & 21.49042 & 110 & -3.49 & 6.3 & 1.9 \\
\hline DEBRECEN HU & 47.47051 & 21.49042 & 110 & -6.26 & 3 & 1.9 \\
\hline DEBRECEN HU & 47.47051 & 21.49042 & 110 & -13.16 & 1.9 & 2 \\
\hline DEBRECEN HU & 47.47051 & 21.49042 & 110 & -12.73 & 4.5 & 2 \\
\hline DEBRECEN HU & 47.47051 & 21.49042 & 110 & -11.51 & 0.9 & 2.1 \\
\hline DEBRECEN HU & 47.47051 & 21.49042 & 110 & -6.96 & 3.4 & 2.2 \\
\hline DEBRECEN HU & 47.47051 & 21.49042 & 110 & -12.38 & 8.7 & 2.3 \\
\hline DEBRECEN HU & 47.47051 & 21.49042 & 110 & -7.49 & 2.5 & 2.4 \\
\hline EEN HU & 47.47051 & 21.49042 & 110 & -4.52 & 0.1 & 2.4 \\
\hline
\end{tabular}




\begin{tabular}{|c|c|c|c|c|c|c|}
\hline DEBRECEN HU & 47.47051 & 21.49042 & 110 & -18.5 & 3.1 & 2.4 \\
\hline DEBRECEN HU & 47.47051 & 21.49042 & 110 & -7.12 & 1.6 & 2.6 \\
\hline DEBRECEN HU & 47.47051 & 21.49042 & 110 & -5.27 & 15.6 & .6 \\
\hline DEBRECEN HU & 47.47051 & 21.49042 & 110 & -11.4 & 5.5 & 2.6 \\
\hline DEBRECEN HU & 47.47051 & 21.49042 & 110 & -8.69 & 0.7 & \\
\hline DEBRECEN HU & 47.47051 & 21.49042 & 110 & -11.41 & 2.2 & 2.7 \\
\hline DEBRECEN HU & 47.47051 & 21.49042 & 110 & -15.75 & 4.1 & 2.7 \\
\hline DEBRECEN HU & 47.47051 & 21.49042 & 110 & -12.59 & 10.5 & 2.8 \\
\hline DEBRECEN HU & 47.47051 & 21.49042 & 110 & -9.76 & 6.2 & 3.1 \\
\hline DEBRECEN HU & 47.47051 & 21.49042 & 110 & -13.36 & 4.8 & 3.3 \\
\hline DEBRECEN HU & 47.47051 & 21.49042 & 110 & -15.76 & 3.9 & 3.3 \\
\hline DEBRECEN HU & 47.47051 & 21.49042 & 110 & -12.7 & 8.1 & 3.4 \\
\hline DEBRECEN HU & 47.47051 & 21.49042 & 110 & -9.66 & 2.3 & . \\
\hline DEBRECEN HU & 47.47051 & 21.49042 & 110 & -8.8 & 0.8 & 3.6 \\
\hline DEBRECEN HU & 47.47051 & 21.49042 & 110 & -9.97 & 14 & 3.7 \\
\hline DEBRECEN HU & 47.47051 & 21.49042 & 110 & -10.02 & 5.5 & 3.7 \\
\hline DEBRECEN HU & 47.47051 & 21.49042 & 110 & -9.87 & 6.5 & 3.7 \\
\hline DEBRECEN HU & 47.47051 & 21.49042 & 110 & -18.54 & 18.9 & 3.7 \\
\hline DEBRECEN HU & 47.47051 & 21.49042 & 110 & -8.7 & 10.4 & 3.8 \\
\hline DEBRECEN HU & 47.47051 & 21.49042 & 110 & -6.11 & 0.5 & 3.8 \\
\hline DEBRECEN HU & 47.47051 & 21.49042 & 110 & -10.78 & 1.7 & 3.8 \\
\hline DEBRECEN HU & 47.47051 & 21.49042 & 110 & -17.25 & 0.7 & \\
\hline DEBRECEN HU & 47.47051 & 21.49042 & 110 & -3.59 & 22.1 & 4.1 \\
\hline DEBRECEN HU & 47.47051 & 21.49042 & 110 & -9.65 & 10.5 & \\
\hline DEBRECEN HU & 47.47051 & 21.49042 & 110 & -12.83 & 10.7 & \\
\hline DEBRECEN HU & 47.47051 & 21.49042 & 110 & -13.09 & 4.6 & 4.2 \\
\hline DEBRECEN HU & 47.47051 & 21.49042 & 110 & -4.32 & 1.8 & .2 \\
\hline DEBRECEN HU & 47.47051 & 21.49042 & 110 & -6.02 & 0.1 & 4.2 \\
\hline DEBRECEN HU & 47.47051 & 21.49042 & 110 & -6.49 & 0.4 & .2 \\
\hline DEBRECEN HU & 47.47051 & 21.49042 & 110 & -12.62 & 14.6 & 4.3 \\
\hline DEBRECEN HU & 47.47051 & 21.49042 & 110 & -12.53 & 10.2 & \\
\hline DEBRECEN HU & 47.47051 & 21.49042 & 110 & -7.07 & 1.5 & .3 \\
\hline DEBRECEN HU & 47.47051 & 21.49042 & 110 & -7.33 & 6.9 & 4.4 \\
\hline DEBRECEN HU & 47.47051 & 21.49042 & 110 & -11.57 & 9.4 & .4 \\
\hline DEBRECEN HU & 47.47051 & 21.49042 & 110 & -13.3 & 1.6 & \\
\hline DEBRECEN HU & 47.47051 & 21.49042 & 110 & -5.2 & 3.3 & 4.6 \\
\hline DEBRECEN HU & 47.47051 & 21.49042 & 110 & -9.53 & 2.2 & 4.6 \\
\hline DEBRECEN HU & 47.47051 & 21.49042 & 110 & -8.45 & 4.1 & .1 \\
\hline DEBRECEN HU & 47.47051 & 21.49042 & 110 & -9.6 & 4.4 & .8 \\
\hline DEBRECEN HU & 47.47051 & 21.49042 & 110 & -13.15 & 11 & .8 \\
\hline DEBRECEN HU & 47.47051 & 21.49042 & 110 & -13.13 & 3.4 & 4.8 \\
\hline DEBRECEN HU & 47.47051 & 21.49042 & 110 & -7.3 & 15.6 & .8 \\
\hline DEBRECEN HU & 47.47051 & 21.49042 & 110 & -6.33 & 6.9 & 4.9 \\
\hline DEBRECEN HU & 47.47051 & 21.49042 & 110 & -10.47 & 6.9 & 4.9 \\
\hline DEBRECEN HU & 47.47051 & 21.49042 & 110 & -6.61 & 21.9 & \\
\hline DEBRECEN HU & 47.47051 & 21.49042 & 110 & 0.83 & 2.5 & \\
\hline DEBRECEN HU & 47.47051 & 21.49042 & 110 & -7.17 & 5.3 & \\
\hline DEBRECEN HU & 47.47051 & 21.49042 & 110 & -14.67 & 21.8 & \\
\hline DEBRECEN HU & 47.47051 & 21.49042 & 110 & -11.52 & 14.2 & \\
\hline DEBRECEN HU & 47.47051 & 21.49042 & 110 & -4.49 & 6.5 & \\
\hline
\end{tabular}




\begin{tabular}{|c|c|c|c|c|c|c|}
\hline DEBRECEN HU & 47.47051 & 21.49042 & 110 & -7.66 & 6.7 & 5.1 \\
\hline DEBRECEN HU & 47.47051 & 21.49042 & 110 & -6.72 & 1.2 & 5.1 \\
\hline DEBRECEN HU & 47.47051 & 21.49042 & 110 & -2.72 & 0.5 & 5.2 \\
\hline DEBRECEN HU & 47.47051 & 21.49042 & 110 & -10.3 & 4.2 & 5.2 \\
\hline DEBRECEN HU & 47.47051 & 21.49042 & 110 & -6.29 & 0.8 & 5.2 \\
\hline DEBRECEN HU & 47.47051 & 21.49042 & 110 & -5.08 & 6 & 5.3 \\
\hline DEBRECEN HU & 47.47051 & 21.49042 & 110 & -5.1 & 1.3 & 5.3 \\
\hline DEBRECEN HU & 47.47051 & 21.49042 & 110 & -10.54 & 15 & 5.4 \\
\hline DEBRECEN HU & 47.47051 & 21.49042 & 110 & -6.14 & 12 & 5.4 \\
\hline DEBRECEN HU & 47.47051 & 21.49042 & 110 & -7.02 & 34.9 & 5.4 \\
\hline DEBRECEN HU & 47.47051 & 21.49042 & 110 & -9.04 & 3.1 & 5.4 \\
\hline DEBRECEN HU & 47.47051 & 21.49042 & 110 & -12.39 & 14.3 & 5.4 \\
\hline DEBRECEN HU & 47.47051 & 21.49042 & 110 & -4.7 & 4.8 & 5.5 \\
\hline DEBRECEN HU & 47.47051 & 21.49042 & 110 & -15.33 & 9.5 & 5.5 \\
\hline DEBRECEN HU & 47.47051 & 21.49042 & 110 & -11.68 & 2 & 5.6 \\
\hline DEBRECEN HU & 47.47051 & 21.49042 & 110 & -9.97 & 2.2 & 5.6 \\
\hline DEBRECEN HU & 47.47051 & 21.49042 & 110 & -5.61 & 0.3 & 5.6 \\
\hline DEBRECEN HU & 47.47051 & 21.49042 & 110 & -10.53 & 11.4 & 5.7 \\
\hline DEBRECEN HU & 47.47051 & 21.49042 & 110 & -12.51 & 11.1 & 5.7 \\
\hline DEBRECEN HU & 47.47051 & 21.49042 & 110 & -7.42 & 0.4 & 5.7 \\
\hline DEBRECEN HU & 47.47051 & 21.49042 & 110 & -6.43 & 0.8 & 5.7 \\
\hline DEBRECEN HU & 47.47051 & 21.49042 & 110 & -11.66 & 1.4 & 5.8 \\
\hline DEBRECEN HU & 47.47051 & 21.49042 & 110 & -16.45 & 5.6 & 5.8 \\
\hline DEBRECEN HU & 47.47051 & 21.49042 & 110 & -4.06 & 27.2 & 5.9 \\
\hline DEBRECEN HU & 47.47051 & 21.49042 & 110 & -5.83 & 5.5 & 5.9 \\
\hline DEBRECEN HU & 47.47051 & 21.49042 & 110 & -7.74 & 4.5 & 5.9 \\
\hline DEBRECEN HU & 47.47051 & 21.49042 & 110 & -11.72 & 18.3 & 5.9 \\
\hline DEBRECEN HU & 47.47051 & 21.49042 & 110 & -9.09 & 3.5 & 5.9 \\
\hline DEBRECEN HU & 47.47051 & 21.49042 & 110 & -7.5 & 15.4 & 5.9 \\
\hline DEBRECEN HU & 47.47051 & 21.49042 & 110 & -7 & 20.2 & 6 \\
\hline DEBRECEN HU & 47.47051 & 21.49042 & 110 & -4.86 & 1.5 & 6 \\
\hline DEBRECEN HU & 47.47051 & 21.49042 & 110 & -6.55 & 6.4 & 6.1 \\
\hline DEBRECEN HU & 47.47051 & 21.49042 & 110 & -8.04 & 3.7 & 6.1 \\
\hline DEBRECEN HU & 47.47051 & 21.49042 & 110 & -12.15 & 5.7 & 6.2 \\
\hline DEBRECEN HU & 47.47051 & 21.49042 & 110 & -7.44 & 2 & 6.2 \\
\hline DEBRECEN HU & 47.47051 & 21.49042 & 110 & -9.05 & 0.3 & 6.2 \\
\hline DEBRECEN HU & 47.47051 & 21.49042 & 110 & -8.33 & 16.6 & 6.3 \\
\hline DEBRECEN HU & 47.47051 & 21.49042 & 110 & -5.5 & 3.5 & 6.3 \\
\hline DEBRECEN HU & 47.47051 & 21.49042 & 110 & -3.77 & 4.4 & 6.4 \\
\hline DEBRECEN HU & 47.47051 & 21.49042 & 110 & -11.08 & 3.8 & 6.5 \\
\hline DEBRECEN HU & 47.47051 & 21.49042 & 110 & -7.84 & 0.5 & 6.6 \\
\hline DEBRECEN HU & 47.47051 & 21.49042 & 110 & -14.38 & 9.4 & 6.6 \\
\hline DEBRECEN HU & 47.47051 & 21.49042 & 110 & -13.12 & 10.5 & 6.7 \\
\hline DEBRECEN HU & 47.47051 & 21.49042 & 110 & -7.51 & 4 & 6.7 \\
\hline DEBRECEN HU & 47.47051 & 21.49042 & 110 & -7.33 & 2.3 & 6.7 \\
\hline DEBRECEN HU & 47.47051 & 21.49042 & 110 & -10 & 11.6 & 6.8 \\
\hline DEBRECEN HU & 47.47051 & 21.49042 & 110 & -13.28 & 33.2 & 6.8 \\
\hline DEBRECEN HU & 47.47051 & 21.49042 & 110 & -11.61 & 5.4 & 6.8 \\
\hline DEBRECEN HU & 47.47051 & 21.49042 & 110 & -14.51 & 4.1 & 6.8 \\
\hline ECEN HU & 47.47051 & 21.49042 & 110 & -5.32 & 3.2 & 6.9 \\
\hline
\end{tabular}




\begin{tabular}{|c|c|c|c|c|c|c|}
\hline DEBRECEN HU & 47.47051 & 21.49042 & 110 & -7.16 & 3.1 & 6.9 \\
\hline DEBRECEN HU & 47.47051 & 21.49042 & 110 & -10.37 & 0.5 & 6.9 \\
\hline DEBRECEN HU & 47.47051 & 21.49042 & 110 & -14.9 & 30.3 & 5.9 \\
\hline DEBRECEN HU & 47.47051 & 21.49042 & 110 & -4.95 & 9.5 & 7 \\
\hline DEBRECEN HU & 47.47051 & 21.49042 & 110 & -8.64 & 5.1 & \\
\hline DEBRECEN HU & 47.47051 & 21.49042 & 110 & -11.4 & 12 & 7.1 \\
\hline DEBRECEN HU & 47.47051 & 21.49042 & 110 & -5.35 & 2.1 & 7.1 \\
\hline DEBRECEN HU & 47.47051 & 21.49042 & 110 & -10.62 & 6 & 7.1 \\
\hline DEBRECEN HU & 47.47051 & 21.49042 & 110 & -6.86 & 13.3 & 73 \\
\hline DEBRECEN HU & 47.47051 & 21.49042 & 110 & -10.85 & 32.7 & 7.4 \\
\hline DEBRECEN HU & 47.47051 & 21.49042 & 110 & -13.17 & 36.6 & .4 \\
\hline DEBRECEN HU & 47.47051 & 21.49042 & 110 & -7.94 & 3.3 & 7.5 \\
\hline DEBRECEN HU & 47.47051 & 21.49042 & 110 & -6.71 & 3.2 & 7.6 \\
\hline DEBRECEN HU & 47.47051 & 21.49042 & 110 & -8.99 & 3.4 & 7.6 \\
\hline DEBRECEN HU & 47.47051 & 21.49042 & 110 & -11.01 & 6.2 & 7.6 \\
\hline DEBRECEN HU & 47.47051 & 21.49042 & 110 & -7.77 & 4.1 & 7.8 \\
\hline DEBRECEN HU & 47.47051 & 21.49042 & 110 & -4.16 & 0.3 & 7.8 \\
\hline DEBRECEN HU & 47.47051 & 21.49042 & 110 & -12.51 & 6.7 & 7.8 \\
\hline DEBRECEN HU & 47.47051 & 21.49042 & 110 & -4.96 & 2.9 & .8 \\
\hline DEBRECEN HU & 47.47051 & 21.49042 & 110 & -4.48 & 1.1 & $7 . \varepsilon$ \\
\hline DEBRECEN HU & 47.47051 & 21.49042 & 110 & -11.4 & 7.3 & 7.9 \\
\hline DEBRECEN HU & 47.47051 & 21.49042 & 110 & -5.31 & 1 & 7.9 \\
\hline DEBRECEN HU & 47.47051 & 21.49042 & 110 & -11.4 & 9.7 & 7.9 \\
\hline DEBRECEN HU & 47.47051 & 21.49042 & 110 & -9.01 & 11.3 & 7.9 \\
\hline DEBRECEN HU & 47.47051 & 21.49042 & 110 & -4.92 & 16.6 & c \\
\hline DEBRECEN HU & 47.47051 & 21.49042 & 110 & -10.99 & 46.2 & \\
\hline DEBRECEN HU & 47.47051 & 21.49042 & 110 & -10.09 & 0.6 & \\
\hline DEBRECEN HU & 47.47051 & 21.49042 & 110 & -7.78 & 13.7 & 3.1. \\
\hline DEBRECEN HU & 47.47051 & 21.49042 & 110 & -10.01 & 8.8 & 8.1 \\
\hline DEBRECEN HU & 47.47051 & 21.49042 & 110 & -8.45 & 6.4 & 8.1 \\
\hline DEBRECEN HU & 47.47051 & 21.49042 & 110 & -8.18 & 11.5 & 8.2 \\
\hline DEBRECEN HU & 47.47051 & 21.49042 & 110 & -9.13 & 7.2 & 8.2 \\
\hline DEBRECEN HU & 47.47051 & 21.49042 & 110 & -9.98 & 8.5 & 8. \\
\hline DEBRECEN HU & 47.47051 & 21.49042 & 110 & -6.85 & 1.2 & 8.3 \\
\hline DEBRECEN HU & 47.47051 & 21.49042 & 110 & -10.18 & 11.2 & 8. \\
\hline DEBRECEN HU & 47.47051 & 21.49042 & 110 & -5.23 & 4 & 8. \\
\hline DEBRECEN HU & 47.47051 & 21.49042 & 110 & -10.51 & 3.1 & 8.6 \\
\hline DEBRECEN HU & 47.47051 & 21.49042 & 110 & -5.85 & 1.2 & 8.6 \\
\hline DEBRECEN HU & 47.47051 & 21.49042 & 110 & -3.43 & 0.1 & 8. \\
\hline DEBRECEN HU & 47.47051 & 21.49042 & 110 & -5.89 & 14 & $8.7-1$ \\
\hline DEBRECEN HU & 47.47051 & 21.49042 & 110 & -2.92 & 22.5 & 8.8 \\
\hline DEBRECEN HU & 47.47051 & 21.49042 & 110 & -4.56 & 2.9 & 8.8 \\
\hline DEBRECEN HU & 47.47051 & 21.49042 & 110 & -14.2 & 5.9 & 8.8 \\
\hline DEBRECEN HU & 47.47051 & 21.49042 & 110 & -6.59 & 10.8 & 8.9 \\
\hline DEBRECEN HU & 47.47051 & 21.49042 & 110 & -7.71 & 5.3 & 8. \\
\hline DEBRECEN HU & 47.47051 & 21.49042 & 110 & -4.33 & 0.8 & \\
\hline DEBRECEN HU & 47.47051 & 21.49042 & 110 & -6.89 & 6.4 & \\
\hline DEBRECEN HU & 47.47051 & 21.49042 & 110 & -5.56 & 3.7 & \\
\hline DEBRECEN HU & 47.47051 & 21.49042 & 110 & -6.76 & 7.8 & \\
\hline DEBRECEN HU & 47.47051 & 21.49042 & 110 & -16.34 & 13.6 & \\
\hline
\end{tabular}




\begin{tabular}{|c|c|c|c|c|c|c|}
\hline DEBRECEN HU & 47.47051 & 21.49042 & 110 & -6.22 & 1.6 & 9.2 \\
\hline DEBRECEN HU & 47.47051 & 21.49042 & 110 & -11.69 & 10.8 & 9.3 \\
\hline DEBRECEN HU & 47.47051 & 21.49042 & 110 & -7.93 & 8.6 & 9.4 \\
\hline DEBRECEN HU & 47.47051 & 21.49042 & 110 & -5.78 & 4.4 & 9.4 \\
\hline DEBRECEN HU & 47.47051 & 21.49042 & 110 & -10.74 & 2.7 & 9.6 \\
\hline DEBRECEN HU & 47.47051 & 21.49042 & 110 & -1.72 & 4.3 & 9.6 \\
\hline DEBRECEN HU & 47.47051 & 21.49042 & 110 & -7.81 & 2.6 & 9.6 \\
\hline DEBRECEN HU & 47.47051 & 21.49042 & 110 & -7.31 & 0.4 & 9.7 \\
\hline DEBRECEN HU & 47.47051 & 21.49042 & 110 & -6.98 & 4.9 & 9.7 \\
\hline DEBRECEN HU & 47.47051 & 21.49042 & 110 & -7.41 & 1.4 & 9.8 \\
\hline DEBRECEN HU & 47.47051 & 21.49042 & 110 & -5.99 & 10 & 10 \\
\hline DEBRECEN HU & 47.47051 & 21.49042 & 110 & -4.78 & 54.3 & 10.1 \\
\hline DEBRECEN HU & 47.47051 & 21.49042 & 110 & -9.59 & 19.1 & 10.1 \\
\hline DEBRECEN HU & 47.47051 & 21.49042 & 110 & -3.42 & 2.8 & 10.2 \\
\hline DEBRECEN HU & 47.47051 & 21.49042 & 110 & -2.88 & 4 & 10.3 \\
\hline DEBRECEN HU & 47.47051 & 21.49042 & 110 & -4.25 & 13.1 & 10.4 \\
\hline DEBRECEN HU & 47.47051 & 21.49042 & 110 & -7.49 & 15.9 & 10.4 \\
\hline DEBRECEN HU & 47.47051 & 21.49042 & 110 & -7.25 & 3.6 & 10.5 \\
\hline DEBRECEN HU & 47.47051 & 21.49042 & 110 & -5.59 & 4.3 & 10.5 \\
\hline DEBRECEN HU & 47.47051 & 21.49042 & 110 & -5.6 & 3.4 & 10.6 \\
\hline DEBRECEN HU & 47.47051 & 21.49042 & 110 & -8.65 & 4.1 & 10.7 \\
\hline DEBRECEN HU & 47.47051 & 21.49042 & 110 & -6.17 & 8.4 & 10.7 \\
\hline DEBRECEN HU & 47.47051 & 21.49042 & 110 & -6.53 & 23 & 10.8 \\
\hline DEBRECEN HU & 47.47051 & 21.49042 & 110 & -5.23 & 6.6 & 10.8 \\
\hline DEBRECEN HU & 47.47051 & 21.49042 & 110 & -6.88 & 14 & 11 \\
\hline DEBRECEN HU & 47.47051 & 21.49042 & 110 & -3.54 & 17.2 & 11.1 \\
\hline DEBRECEN HU & 47.47051 & 21.49042 & 110 & -3.85 & 33.5 & 11.1 \\
\hline DEBRECEN HU & 47.47051 & 21.49042 & 110 & -5 & 6.9 & 11.1 \\
\hline DEBRECEN HU & 47.47051 & 21.49042 & 110 & -5.35 & 2.7 & 11.1 \\
\hline DEBRECEN HU & 47.47051 & 21.49042 & 110 & -11.69 & 21.1 & 11.2 \\
\hline DEBRECEN HU & 47.47051 & 21.49042 & 110 & -10.75 & 20.7 & 11.2 \\
\hline DEBRECEN HU & 47.47051 & 21.49042 & 110 & -8 & 32.8 & 11.2 \\
\hline DEBRECEN HU & 47.47051 & 21.49042 & 110 & -8.64 & 5.1 & 11.2 \\
\hline DEBRECEN HU & 47.47051 & 21.49042 & 110 & -7.59 & 21 & 11.3 \\
\hline DEBRECEN HU & 47.47051 & 21.49042 & 110 & -8.62 & 13.6 & 11.3 \\
\hline DEBRECEN HU & 47.47051 & 21.49042 & 110 & -3.65 & 4.9 & 11.4 \\
\hline DEBRECEN HU & 47.47051 & 21.49042 & 110 & -9.64 & 11.2 & 11.5 \\
\hline DEBRECEN HU & 47.47051 & 21.49042 & 110 & -8.7 & 14.3 & 11.5 \\
\hline DEBRECEN HU & 47.47051 & 21.49042 & 110 & -3.89 & 8.9 & 11.7 \\
\hline DEBRECEN HU & 47.47051 & 21.49042 & 110 & -7.11 & 0.3 & 11.8 \\
\hline DEBRECEN HU & 47.47051 & 21.49042 & 110 & -9.91 & 26.9 & 11.8 \\
\hline DEBRECEN HU & 47.47051 & 21.49042 & 110 & -9.95 & 17.2 & 11.9 \\
\hline DEBRECEN HU & 47.47051 & 21.49042 & 110 & -5.86 & 4.7 & 11.9 \\
\hline DEBRECEN HU & 47.47051 & 21.49042 & 110 & -4.43 & 3 & 11.9 \\
\hline DEBRECEN HU & 47.47051 & 21.49042 & 110 & -4.64 & 9 & 11.9 \\
\hline DEBRECEN HU & 47.47051 & 21.49042 & 110 & -10.54 & 11.1 & 11.9 \\
\hline DEBRECEN HU & 47.47051 & 21.49042 & 110 & -4.21 & 1.3 & 11.9 \\
\hline DEBRECEN HU & 47.47051 & 21.49042 & 110 & -12.01 & 7.8 & 12 \\
\hline DEBRECEN HU & 47.47051 & 21.49042 & 110 & -5.94 & 3.9 & 12 \\
\hline EN HU & 47.47051 & 21.49042 & 110 & -10.01 & 3.6 & 12 \\
\hline
\end{tabular}




\begin{tabular}{|c|c|c|c|c|c|c|}
\hline DEBRECEN HU & 47.47051 & 21.49042 & 110 & 0.08 & 9.9 & 12.1 \\
\hline DEBRECEN HU & 47.47051 & 21.49042 & 110 & -13 & 32.1 & 12.1 \\
\hline DEBRECEN HU & 47.47051 & 21.49042 & 110 & -9 & 25.7 & 12.1 \\
\hline DEBRECEN HU & 47.47051 & 21.49042 & 110 & -6.9 & 15.8 & 12.2 \\
\hline DEBRECEN HU & 47.47051 & 21.49042 & 110 & -2.36 & 1.3 & 2.3 \\
\hline DEBRECEN HU & 47.47051 & 21.49042 & 110 & -7.88 & 6.4 & 12.3 \\
\hline DEBRECEN HU & 47.47051 & 21.49042 & 110 & -5.24 & 1.8 & 12.4 \\
\hline DEBRECEN HU & 47.47051 & 21.49042 & 110 & -2.1 & 4.2 & 12.5 \\
\hline DEBRECEN HU & 47.47051 & 21.49042 & 110 & -11.15 & 7.4 & 12.5 \\
\hline DEBRECEN HU & 47.47051 & 21.49042 & 110 & -6.79 & 9.9 & 12.5 \\
\hline DEBRECEN HU & 47.47051 & 21.49042 & 110 & -11.99 & 10.5 & 12.5 \\
\hline DEBRECEN HU & 47.47051 & 21.49042 & 110 & -2.51 & 3.7 & 12.5 \\
\hline DEBRECEN HU & 47.47051 & 21.49042 & 110 & -3.38 & 9.5 & 6 \\
\hline DEBRECEN HU & 47.47051 & 21.49042 & 110 & -8.87 & 2.4 & 12.6 \\
\hline DEBRECEN HU & 47.47051 & 21.49042 & 110 & -5.58 & 4.7 & 12.6 \\
\hline DEBRECEN HU & 47.47051 & 21.49042 & 110 & -8.51 & 8 & 12.6 \\
\hline DEBRECEN HU & 47.47051 & 21.49042 & 110 & -3.81 & 1 & 12.7 \\
\hline DEBRECEN HU & 47.47051 & 21.49042 & 110 & -10.18 & 25 & 12.8 \\
\hline DEBRECEN HU & 47.47051 & 21.49042 & 110 & -6.22 & 10.4 & 12.8 \\
\hline DEBRECEN HU & 47.47051 & 21.49042 & 110 & -7.33 & 35.9 & 12.9 \\
\hline DEBRECEN HU & 47.47051 & 21.49042 & 110 & -8.73 & 19.3 & 13 \\
\hline DEBRECEN HU & 47.47051 & 21.49042 & 110 & 0.83 & 1.2 & 13 \\
\hline DEBRECEN HU & 47.47051 & 21.49042 & 110 & -11.14 & 11.3 & 13 \\
\hline DEBRECEN HU & 47.47051 & 21.49042 & 110 & -11.6 & 0.5 & 13.1 \\
\hline DEBRECEN HU & 47.47051 & 21.49042 & 110 & -10.45 & 11.8 & \\
\hline DEBRECEN HU & 47.47051 & 21.49042 & 110 & -7.11 & 4.7 & 13.2 \\
\hline DEBRECEN HU & 47.47051 & 21.49042 & 110 & -11.81 & 3.1 & .2 \\
\hline DEBRECEN HU & 47.47051 & 21.49042 & 110 & -8.95 & 20.5 & 13.3 \\
\hline DEBRECEN HU & 47.47051 & 21.49042 & 110 & -9.44 & 11.4 & 13.3 \\
\hline DEBRECEN HU & 47.47051 & 21.49042 & 110 & -13.6 & 11.5 & 13.4 \\
\hline DEBRECEN HU & 47.47051 & 21.49042 & 110 & -7.57 & 3.5 & 13.4 \\
\hline DEBRECEN HU & 47.47051 & 21.49042 & 110 & -6.45 & 9 & 13.4 \\
\hline DEBRECEN HU & 47.47051 & 21.49042 & 110 & -9.18 & 8.4 & 13.5 \\
\hline DEBRECEN HU & 47.47051 & 21.49042 & 110 & -3.6 & 3.8 & 13.5 \\
\hline DEBRECEN HU & 47.47051 & 21.49042 & 110 & -11.06 & 9.7 & 13.5 \\
\hline DEBRECEN HU & 47.47051 & 21.49042 & 110 & -7.97 & 11.5 & 13.6 \\
\hline DEBRECEN HU & 47.47051 & 21.49042 & 110 & -5.8 & 40.3 & 13.7 \\
\hline DEBRECEN HU & 47.47051 & 21.49042 & 110 & -7.08 & 4.1 & 13.7 \\
\hline DEBRECEN HU & 47.47051 & 21.49042 & 110 & -4.01 & 7.9 & 13.8 \\
\hline DEBRECEN HU & 47.47051 & 21.49042 & 110 & -9.34 & 7.9 & 13.8 \\
\hline DEBRECEN HU & 47.47051 & 21.49042 & 110 & -4.41 & 2.8 & 13.9 \\
\hline DEBRECEN HU & 47.47051 & 21.49042 & 110 & -9.5 & 22.4 & 14.1 \\
\hline DEBRECEN HU & 47.47051 & 21.49042 & 110 & -2.3 & 6.7 & 14.2 \\
\hline DEBRECEN HU & 47.47051 & 21.49042 & 110 & -4.9 & 6.9 & 14.2 \\
\hline DEBRECEN HU & 47.47051 & 21.49042 & 110 & -1.92 & 0.4 & 14.2 \\
\hline DEBRECEN HU & 47.47051 & 21.49042 & 110 & -6.24 & 10.2 & 14.2 \\
\hline DEBRECEN HU & 47.47051 & 21.49042 & 110 & -7.5 & 12 & 14.3 \\
\hline DEBRECEN HU & 47.47051 & 21.49042 & 110 & -4.24 & 0.1 & 14.3 \\
\hline DEBRECEN HU & 47.47051 & 21.49042 & 110 & -1.59 & 3.3 & 14.3 \\
\hline DEBRECEN HU & 47.47051 & 21.49042 & 110 & -4.17 & 11.4 & \\
\hline
\end{tabular}




\begin{tabular}{|c|c|c|c|c|c|c|}
\hline DEBRECEN HU & 47.47051 & 21.49042 & 110 & -4 & 31.8 & 14.4 \\
\hline DEBRECEN HU & 47.47051 & 21.49042 & 110 & -6.49 & 0.2 & 14.5 \\
\hline DEBRECEN HU & 47.47051 & 21.49042 & 110 & -5.24 & 50.8 & 14.6 \\
\hline DEBRECEN HU & 47.47051 & 21.49042 & 110 & -9.89 & 12.9 & 14.6 \\
\hline DEBRECEN HU & 47.47051 & 21.49042 & 110 & -9.66 & 3.8 & 14.6 \\
\hline DEBRECEN HU & 47.47051 & 21.49042 & 110 & 0.7 & 46.9 & 14.8 \\
\hline DEBRECEN HU & 47.47051 & 21.49042 & 110 & -7.48 & 0.7 & 14.8 \\
\hline DEBRECEN HU & 47.47051 & 21.49042 & 110 & -6.92 & 11.6 & 14.8 \\
\hline DEBRECEN HU & 47.47051 & 21.49042 & 110 & -7.05 & 3.1 & 14.9 \\
\hline DEBRECEN HU & 47.47051 & 21.49042 & 110 & -4.58 & 1.2 & 14.9 \\
\hline DEBRECEN HU & 47.47051 & 21.49042 & 110 & -6.29 & 11.7 & 15 \\
\hline DEBRECEN HU & 47.47051 & 21.49042 & 110 & 0.25 & 0.5 & 15 \\
\hline DEBRECEN HU & 47.47051 & 21.49042 & 110 & -6 & 19.3 & 15 \\
\hline DEBRECEN HU & 47.47051 & 21.49042 & 110 & -6.25 & 2.3 & 15.1 \\
\hline DEBRECEN HU & 47.47051 & 21.49042 & 110 & -6.16 & 18.9 & 15.1 \\
\hline DEBRECEN HU & 47.47051 & 21.49042 & 110 & -7.74 & 0.2 & 15.1 \\
\hline DEBRECEN HU & 47.47051 & 21.49042 & 110 & -10.18 & 15.1 & 15.1 \\
\hline DEBRECEN HU & 47.47051 & 21.49042 & 110 & -1.03 & 16.5 & 15.2 \\
\hline DEBRECEN HU & 47.47051 & 21.49042 & 110 & -3.8 & 13.1 & 15.3 \\
\hline DEBRECEN HU & 47.47051 & 21.49042 & 110 & -6.87 & 7.7 & 15.3 \\
\hline DEBRECEN HU & 47.47051 & 21.49042 & 110 & -13.7 & 0.1 & 15.4 \\
\hline DEBRECEN HU & 47.47051 & 21.49042 & 110 & -5.88 & 10.4 & 15.4 \\
\hline DEBRECEN HU & 47.47051 & 21.49042 & 110 & -4.11 & 5 & 15.5 \\
\hline DEBRECEN HU & 47.47051 & 21.49042 & 110 & -0.64 & 1.5 & 15.6 \\
\hline DEBRECEN HU & 47.47051 & 21.49042 & 110 & -10.8 & 34.9 & 15.6 \\
\hline DEBRECEN HU & 47.47051 & 21.49042 & 110 & -6.03 & 1.7 & 15.7 \\
\hline DEBRECEN HU & 47.47051 & 21.49042 & 110 & -12.34 & 60.3 & 15.8 \\
\hline DEBRECEN HU & 47.47051 & 21.49042 & 110 & -4.68 & 5.3 & 15.8 \\
\hline DEBRECEN HU & 47.47051 & 21.49042 & 110 & -7.79 & 4.3 & 15.8 \\
\hline DEBRECEN HU & 47.47051 & 21.49042 & 110 & -3.86 & 15.4 & 16 \\
\hline DEBRECEN HU & 47.47051 & 21.49042 & 110 & -12.22 & 18 & 16.1 \\
\hline DEBRECEN HU & 47.47051 & 21.49042 & 110 & -11.6 & 12.6 & 16.1 \\
\hline DEBRECEN HU & 47.47051 & 21.49042 & 110 & -7.46 & 12.5 & 16.1 \\
\hline DEBRECEN HU & 47.47051 & 21.49042 & 110 & -8.99 & 1.5 & 16.3 \\
\hline DEBRECEN HU & 47.47051 & 21.49042 & 110 & -11.24 & 12.3 & 16.4 \\
\hline DEBRECEN HU & 47.47051 & 21.49042 & 110 & -1.72 & 0.3 & 16.5 \\
\hline DEBRECEN HU & 47.47051 & 21.49042 & 110 & -5.26 & 24.2 & 16.5 \\
\hline DEBRECEN HU & 47.47051 & 21.49042 & 110 & -6.5 & 11 & 16.5 \\
\hline DEBRECEN HU & 47.47051 & 21.49042 & 110 & -3.38 & 3.8 & 16.5 \\
\hline DEBRECEN HU & 47.47051 & 21.49042 & 110 & -3.15 & 8.2 & 16.5 \\
\hline DEBRECEN HU & 47.47051 & 21.49042 & 110 & -3.44 & 3.3 & 16.5 \\
\hline DEBRECEN HU & 47.47051 & 21.49042 & 110 & -9.9 & 24.5 & 16.5 \\
\hline DEBRECEN HU & 47.47051 & 21.49042 & 110 & -5.93 & 13.3 & 16.6 \\
\hline DEBRECEN HU & 47.47051 & 21.49042 & 110 & -5.45 & 4.1 & 16.6 \\
\hline DEBRECEN HU & 47.47051 & 21.49042 & 110 & -9.72 & 7 & 16.7 \\
\hline DEBRECEN HU & 47.47051 & 21.49042 & 110 & -1.5 & 5.6 & 16.8 \\
\hline DEBRECEN HU & 47.47051 & 21.49042 & 110 & -5.73 & 14.7 & 16.9 \\
\hline DEBRECEN HU & 47.47051 & 21.49042 & 110 & -6.63 & 7.1 & 16.9 \\
\hline DEBRECEN HU & 47.47051 & 21.49042 & 110 & 0.04 & 14.2 & 17 \\
\hline DEBRECEN HU & 051 & .49042 & 0 & -0.65 & 2 & 17 \\
\hline
\end{tabular}




\begin{tabular}{|c|c|c|c|c|c|c|}
\hline DEBRECEN HU & 47.47051 & 21.49042 & 110 & -8.96 & 11.7 & 17 \\
\hline DEBRECEN HU & 47.47051 & 21.49042 & 110 & -5.78 & 7.4 & 17 \\
\hline DEBRECEN HU & 47.47051 & 21.49042 & 110 & -8.9 & 10 & 17 \\
\hline DEBRECEN HU & 47.47051 & 21.49042 & 110 & -6.34 & 13 & 17 \\
\hline DEBRECEN HU & 47.47051 & 21.49042 & 110 & -4.06 & 0.6 & 17.1 \\
\hline DEBRECEN HU & 47.47051 & 21.49042 & 110 & -5.11 & 11.3 & 17.1 \\
\hline DEBRECEN HU & 47.47051 & 21.49042 & 110 & -8.14 & 42.5 & 17.1 \\
\hline DEBRECEN HU & 47.47051 & 21.49042 & 110 & -1.47 & 2 & 17.1 \\
\hline DEBRECEN HU & 47.47051 & 21.49042 & 110 & -7.81 & 10.1 & 17.1 \\
\hline DEBRECEN HU & 47.47051 & 21.49042 & 110 & -4.32 & 4.1 & 17.1 \\
\hline DEBRECEN HU & 47.47051 & 21.49042 & 110 & 0.51 & 8.6 & 17.2 \\
\hline DEBRECEN HU & 47.47051 & 21.49042 & 110 & -4.85 & 1.4 & 17.2 \\
\hline DEBRECEN HU & 47.47051 & 21.49042 & 110 & -6.27 & 5.1 & 17.2 \\
\hline DEBRECEN HU & 47.47051 & 21.49042 & 110 & -7.66 & 49.8 & 17.3 \\
\hline DEBRECEN HU & 47.47051 & 21.49042 & 110 & -8.07 & 3.6 & 17.3 \\
\hline DEBRECEN HU & 47.47051 & 21.49042 & 110 & -6.17 & 29 & 17.3 \\
\hline DEBRECEN HU & 47.47051 & 21.49042 & 110 & -7.9 & 14.6 & 17.3 \\
\hline DEBRECEN HU & 47.47051 & 21.49042 & 110 & -4 & 8.6 & 17.4 \\
\hline DEBRECEN HU & 47.47051 & 21.49042 & 110 & -14.18 & 11.8 & 17.4 \\
\hline DEBRECEN HU & 47.47051 & 21.49042 & 110 & -8.4 & 10 & 17.4 \\
\hline DEBRECEN HU & 47.47051 & 21.49042 & 110 & -4.37 & 7.4 & 17.4 \\
\hline DEBRECEN HU & 47.47051 & 21.49042 & 110 & -5.34 & 1.9 & 17.6 \\
\hline DEBRECEN HU & 47.47051 & 21.49042 & 110 & -4.99 & 5.9 & 17.6 \\
\hline DEBRECEN HU & 47.47051 & 21.49042 & 110 & -1.32 & 35.2 & 17.7 \\
\hline DEBRECEN HU & 47.47051 & 21.49042 & 110 & -7.62 & 3.9 & 17.7 \\
\hline DEBRECEN HU & 47.47051 & 21.49042 & 110 & -4.77 & 11 & 17.7 \\
\hline DEBRECEN HU & 47.47051 & 21.49042 & 110 & -3.82 & 7.6 & 17.7 \\
\hline DEBRECEN HU & 47.47051 & 21.49042 & 110 & -4.98 & 25.4 & 17.9 \\
\hline DEBRECEN HU & 47.47051 & 21.49042 & 110 & -4.18 & 25.8 & 18 \\
\hline DEBRECEN HU & 47.47051 & 21.49042 & 110 & -7.11 & 0.6 & 18 \\
\hline DEBRECEN HU & 47.47051 & 21.49042 & 110 & -5.45 & 2.4 & 18 \\
\hline DEBRECEN HU & 47.47051 & 21.49042 & 110 & -3.78 & 3.2 & 18 \\
\hline DEBRECEN HU & 47.47051 & 21.49042 & 110 & -1.17 & 0.8 & 18 \\
\hline DEBRECEN HU & 47.47051 & 21.49042 & 110 & -5.23 & 51.8 & 18.1 \\
\hline DEBRECEN HU & 47.47051 & 21.49042 & 110 & -3.96 & 0.6 & 18.1 \\
\hline DEBRECEN HU & 47.47051 & 21.49042 & 110 & -5.32 & 4.6 & 18.2 \\
\hline DEBRECEN HU & 47.47051 & 21.49042 & 110 & -3.31 & 3.8 & 18.2 \\
\hline DEBRECEN HU & 47.47051 & 21.49042 & 110 & -2.28 & 1.3 & 18.2 \\
\hline DEBRECEN HU & 47.47051 & 21.49042 & 110 & -6.64 & 11.6 & 18.3 \\
\hline DEBRECEN HU & 47.47051 & 21.49042 & 110 & -5.22 & 11.8 & 18.3 \\
\hline DEBRECEN HU & 47.47051 & 21.49042 & 110 & -5.9 & 10.5 & 18.4 \\
\hline DEBRECEN HU & 47.47051 & 21.49042 & 110 & -2.15 & 2.9 & 18.4 \\
\hline DEBRECEN HU & 47.47051 & 21.49042 & 110 & -0.36 & 0.6 & 18.4 \\
\hline DEBRECEN HU & 47.47051 & 21.49042 & 110 & 1.38 & 3.5 & 18.5 \\
\hline DEBRECEN HU & 47.47051 & 21.49042 & 110 & -12.48 & 9.1 & 18.5 \\
\hline DEBRECEN HU & 47.47051 & 21.49042 & 110 & -2.49 & 2.5 & 18.6 \\
\hline DEBRECEN HU & 47.47051 & 21.49042 & 110 & -4.58 & 15 & 18.7 \\
\hline DEBRECEN HU & 47.47051 & 21.49042 & 110 & -5.93 & 9.2 & 18.7 \\
\hline DEBRECEN HU & 47.47051 & 21.49042 & 110 & -5.43 & 40.9 & 18.7 \\
\hline DEBRECEN HU & 47051 & .49042 & LO & 65 & 19 & 18 \\
\hline
\end{tabular}




\begin{tabular}{|c|c|c|c|c|c|c|}
\hline DEBRECEN HU & 47.47051 & 21.49042 & 110 & -6.31 & 19.7 & 18.8 \\
\hline DEBRECEN HU & 47.47051 & 21.49042 & 110 & -7 & 8 & 18.8 \\
\hline DEBRECEN HU & 47.47051 & 21.49042 & 110 & -4.08 & 4.9 & 18.9 \\
\hline DEBRECEN HU & 47.47051 & 21.49042 & 110 & -2.56 & 8.5 & 18.9 \\
\hline DEBRECEN HU & 47.47051 & 21.49042 & 110 & -4.45 & 1.4 & 18.9 \\
\hline DEBRECEN HU & 47.47051 & 21.49042 & 110 & -4.27 & 12.3 & 18.9 \\
\hline DEBRECEN HU & 47.47051 & 21.49042 & 110 & -5.38 & 6.4 & 19 \\
\hline DEBRECEN HU & 47.47051 & 21.49042 & 110 & -6.88 & 18.4 & 19.1 \\
\hline DEBRECEN HU & 47.47051 & 21.49042 & 110 & -1.56 & 0.6 & 19.1 \\
\hline DEBRECEN HU & 47.47051 & 21.49042 & 110 & -4.9 & 24.2 & 19.2 \\
\hline DEBRECEN HU & 47.47051 & 21.49042 & 110 & -5.33 & 4.3 & 19.2 \\
\hline DEBRECEN HU & 47.47051 & 21.49042 & 110 & -5.54 & 11 & 19.2 \\
\hline DEBRECEN HU & 47.47051 & 21.49042 & 110 & -5.16 & 3.3 & 19.2 \\
\hline DEBRECEN HU & 47.47051 & 21.49042 & 110 & -7.84 & 31.8 & 19.3 \\
\hline DEBRECEN HU & 47.47051 & 21.49042 & 110 & -11.23 & 0.2 & 19.3 \\
\hline DEBRECEN HU & 47.47051 & 21.49042 & 110 & -5.22 & 10.1 & 19.3 \\
\hline DEBRECEN HU & 47.47051 & 21.49042 & 110 & -13.58 & 4.7 & 19.3 \\
\hline DEBRECEN HU & 47.47051 & 21.49042 & 110 & -5.86 & 6.2 & 19.3 \\
\hline DEBRECEN HU & 47.47051 & 21.49042 & 110 & -8.8 & 90.9 & 19.4 \\
\hline DEBRECEN HU & 47.47051 & 21.49042 & 110 & -2.33 & 6.5 & 19.4 \\
\hline DEBRECEN HU & 47.47051 & 21.49042 & 110 & -3.19 & 7.6 & 19.4 \\
\hline DEBRECEN HU & 47.47051 & 21.49042 & 110 & -9.43 & 3.9 & 19.4 \\
\hline DEBRECEN HU & 47.47051 & 21.49042 & 110 & -7.03 & 5.8 & 19.5 \\
\hline DEBRECEN HU & 47.47051 & 21.49042 & 110 & -4.29 & 1.9 & 19.5 \\
\hline DEBRECEN HU & 47.47051 & 21.49042 & 110 & -5.13 & 0.3 & 19.6 \\
\hline DEBRECEN HU & 47.47051 & 21.49042 & 110 & -4.84 & 7.6 & 19.6 \\
\hline DEBRECEN HU & 47.47051 & 21.49042 & 110 & -5.62 & 1 & 19.7 \\
\hline DEBRECEN HU & 47.47051 & 21.49042 & 110 & -4.24 & 5.6 & 19.7 \\
\hline DEBRECEN HU & 47.47051 & 21.49042 & 110 & -0.19 & 0.7 & 19.8 \\
\hline DEBRECEN HU & 47.47051 & 21.49042 & 110 & -2.87 & 0.7 & 19.8 \\
\hline DEBRECEN HU & 47.47051 & 21.49042 & 110 & -7.91 & 1.7 & 19.9 \\
\hline DEBRECEN HU & 47.47051 & 21.49042 & 110 & -5.02 & 43.2 & 19.9 \\
\hline DEBRECEN HU & 47.47051 & 21.49042 & 110 & -6.47 & 7.7 & 19.9 \\
\hline DEBRECEN HU & 47.47051 & 21.49042 & 110 & -5.29 & 1.5 & 20 \\
\hline DEBRECEN HU & 47.47051 & 21.49042 & 110 & -5.22 & 25.1 & 20 \\
\hline DEBRECEN HU & 47.47051 & 21.49042 & 110 & -1.35 & 8 & 20 \\
\hline DEBRECEN HU & 47.47051 & 21.49042 & 110 & -6.23 & 6.1 & 20 \\
\hline DEBRECEN HU & 47.47051 & 21.49042 & 110 & -6.74 & 17.8 & 20 \\
\hline DEBRECEN HU & 47.47051 & 21.49042 & 110 & 4.31 & 1.1 & 20.2 \\
\hline DEBRECEN HU & 47.47051 & 21.49042 & 110 & -7.92 & 35.5 & 20.3 \\
\hline DEBRECEN HU & 47.47051 & 21.49042 & 110 & -4.32 & 50.9 & 20.3 \\
\hline DEBRECEN HU & 47.47051 & 21.49042 & 110 & -2.45 & 2.2 & 20.3 \\
\hline DEBRECEN HU & 47.47051 & 21.49042 & 110 & -1.81 & 1.6 & 20.3 \\
\hline DEBRECEN HU & 47.47051 & 21.49042 & 110 & -2.77 & 2.7 & 20.3 \\
\hline DEBRECEN HU & 47.47051 & 21.49042 & 110 & -6.87 & 5 & 20.5 \\
\hline DEBRECEN HU & 47.47051 & 21.49042 & 110 & -2.39 & 10 & 20.5 \\
\hline DEBRECEN HU & 47.47051 & 21.49042 & 110 & -8.25 & 14.6 & 20.6 \\
\hline DEBRECEN HU & 47.47051 & 21.49042 & 110 & -7.18 & 6.5 & 20.6 \\
\hline DEBRECEN HU & 47.47051 & 21.49042 & 110 & -5.33 & 1.7 & 20.6 \\
\hline EN HU & 47.47051 & 21.49042 & 110 & 1.76 & 1.9 & 20.7 \\
\hline
\end{tabular}




\begin{tabular}{|c|c|c|c|c|c|c|}
\hline DEBRECEN HU & 47.47051 & 21.49042 & 110 & -8.18 & 0.4 & 20.8 \\
\hline DEBRECEN HU & 47.47051 & 21.49042 & 110 & 4.28 & 1.4 & 20.9 \\
\hline DEBRECEN HU & 47.47051 & 21.49042 & 110 & -1.72 & 0.1 & 20.9 \\
\hline DEBRECEN HU & 47.47051 & 21.49042 & 110 & -6.27 & 13.8 & 21 \\
\hline DEBRECEN HU & 47.47051 & 21.49042 & 110 & -5.91 & 14.3 & 21.1 \\
\hline DEBRECEN HU & 47.47051 & 21.49042 & 110 & -3.16 & 0.5 & 21.1 \\
\hline DEBRECEN HU & 47.47051 & 21.49042 & 110 & -4.9 & 31.7 & 21.1 \\
\hline DEBRECEN HU & 47.47051 & 21.49042 & 110 & 6.6 & 0.1 & 21.1 \\
\hline DEBRECEN HU & 47.47051 & 21.49042 & 110 & -5.61 & 1.6 & 21.1 \\
\hline DEBRECEN HU & 47.47051 & 21.49042 & 110 & -4.53 & 9.7 & 21.1 \\
\hline DEBRECEN HU & 47.47051 & 21.49042 & 110 & -2.33 & 0.7 & 21.2 \\
\hline DEBRECEN HU & 47.47051 & 21.49042 & 110 & -3.53 & 5.8 & 21.2 \\
\hline DEBRECEN HU & 47.47051 & 21.49042 & 110 & -3.27 & 5.7 & 21.3 \\
\hline DEBRECEN HU & 47.47051 & 21.49042 & 110 & -1.78 & 10.2 & 21.4 \\
\hline DEBRECEN HU & 47.47051 & 21.49042 & 110 & -4.06 & 0.4 & 21.4 \\
\hline DEBRECEN HU & 47.47051 & 21.49042 & 110 & -0.56 & 3.9 & 21.4 \\
\hline DEBRECEN HU & 47.47051 & 21.49042 & 110 & -2.53 & 5.2 & 21.5 \\
\hline DEBRECEN HU & 47.47051 & 21.49042 & 110 & -5 & 16.8 & 21.6 \\
\hline DEBRECEN HU & 47.47051 & 21.49042 & 110 & -3.24 & 0.6 & 21.6 \\
\hline DEBRECEN HU & 47.47051 & 21.49042 & 110 & -3.9 & 3 & 21.6 \\
\hline DEBRECEN HU & 47.47051 & 21.49042 & 110 & -3.46 & 7.1 & 21.6 \\
\hline DEBRECEN HU & 47.47051 & 21.49042 & 110 & -6.16 & 5.5 & 21.8 \\
\hline DEBRECEN HU & 47.47051 & 21.49042 & 110 & -8.68 & 8.7 & 21.9 \\
\hline DEBRECEN HU & 47.47051 & 21.49042 & 110 & 5.28 & 6.2 & 21.9 \\
\hline DEBRECEN HU & 47.47051 & 21.49042 & 110 & -6.77 & 5.3 & 22 \\
\hline DEBRECEN HU & 47.47051 & 21.49042 & 110 & -3.24 & 8.1 & 22.1 \\
\hline DEBRECEN HU & 47.47051 & 21.49042 & 110 & -3.24 & 9.2 & 22.1 \\
\hline DEBRECEN HU & 47.47051 & 21.49042 & 110 & 3 & 2.7 & 22.3 \\
\hline DEBRECEN HU & 47.47051 & 21.49042 & 110 & -2.81 & 4.1 & 22.3 \\
\hline DEBRECEN HU & 47.47051 & 21.49042 & 110 & 0.91 & 49 & 22.4 \\
\hline DEBRECEN HU & 47.47051 & 21.49042 & 110 & -1.39 & 46.2 & 22.4 \\
\hline DEBRECEN HU & 47.47051 & 21.49042 & 110 & 1.9 & 1.5 & 22.4 \\
\hline DEBRECEN HU & 47.47051 & 21.49042 & 110 & -8.63 & 8.2 & 22.4 \\
\hline DEBRECEN HU & 47.47051 & 21.49042 & 110 & 6.64 & 23 & 22.5 \\
\hline DEBRECEN HU & 47.47051 & 21.49042 & 110 & -4.33 & 8.5 & 22.5 \\
\hline DEBRECEN HU & 47.47051 & 21.49042 & 110 & -3.28 & 3.4 & 22.5 \\
\hline DEBRECEN HU & 47.47051 & 21.49042 & 110 & -4.09 & 7.2 & 22.6 \\
\hline DEBRECEN HU & 47.47051 & 21.49042 & 110 & -5.2 & 18.6 & 22.6 \\
\hline DEBRECEN HU & 47.47051 & 21.49042 & 110 & -3.66 & 3 & 22.7 \\
\hline DEBRECEN HU & 47.47051 & 21.49042 & 110 & -4.98 & 9 & 22.8 \\
\hline DEBRECEN HU & 47.47051 & 21.49042 & 110 & -6.66 & 2.6 & 22.8 \\
\hline DEBRECEN HU & 47.47051 & 21.49042 & 110 & -6.12 & 11.1 & 22.8 \\
\hline DEBRECEN HU & 47.47051 & 21.49042 & 110 & -5.38 & 7.3 & 22.8 \\
\hline DEBRECEN HU & 47.47051 & 21.49042 & 110 & 0.44 & 0.4 & 22.8 \\
\hline DEBRECEN HU & 47.47051 & 21.49042 & 110 & -4.19 & 10 & 22.9 \\
\hline DEBRECEN HU & 47.47051 & 21.49042 & 110 & -4.92 & 19.9 & 23 \\
\hline DEBRECEN HU & 47.47051 & 21.49042 & 110 & -2.15 & 3 & 23.1 \\
\hline DEBRECEN HU & 47.47051 & 21.49042 & 110 & -4.44 & 18.7 & 23.1 \\
\hline DEBRECEN HU & 47.47051 & 21.49042 & 110 & -5.24 & 27.1 & 23.2 \\
\hline $\mathrm{N}$ & .47051 & .49042 & 0 & 37 & 1 & \\
\hline
\end{tabular}




\begin{tabular}{|c|c|c|c|c|c|c|}
\hline DEBRECEN HU & 47.47051 & 21.49042 & 110 & -2.94 & 6.4 & 23.2 \\
\hline DEBRECEN HU & 47.47051 & 21.49042 & 110 & -3.61 & 27.7 & 23.2 \\
\hline DEBRECEN HU & 47.47051 & 21.49042 & 110 & 0.88 & 0.1 & 23.2 \\
\hline DEBRECEN HU & 47.47051 & 21.49042 & 110 & 2.77 & 1.4 & 23.3 \\
\hline DEBRECEN HU & 47.47051 & 21.49042 & 110 & -4.3 & 4.1 & 23.3 \\
\hline DEBRECEN HU & 47.47051 & 21.49042 & 110 & -0.78 & 3.9 & 23.4 \\
\hline DEBRECEN HU & 47.47051 & 21.49042 & 110 & -4.44 & 7 & 23.4 \\
\hline DEBRECEN HU & 47.47051 & 21.49042 & 110 & -0.7 & 62.1 & 23.6 \\
\hline DEBRECEN HU & 47.47051 & 21.49042 & 110 & -7.35 & 37 & 23.6 \\
\hline DEBRECEN HU & 47.47051 & 21.49042 & 110 & -4.2 & 10.7 & 23.6 \\
\hline DEBRECEN HU & 47.47051 & 21.49042 & 110 & -2.31 & 3.7 & 23.6 \\
\hline DEBRECEN HU & 47.47051 & 21.49042 & 110 & -3.31 & 6.8 & 23.9 \\
\hline DEBRECEN HU & 47.47051 & 21.49042 & 110 & -3.18 & 12.3 & 24 \\
\hline DEBRECEN HU & 47.47051 & 21.49042 & 110 & -3.4 & 6.7 & 24 \\
\hline DEBRECEN HU & 47.47051 & 21.49042 & 110 & -4.32 & 10 & 4.1 \\
\hline DEBRECEN HU & 47.47051 & 21.49042 & 110 & -1.51 & 2.1 & 24.4 \\
\hline DEBRECEN HU & 47.47051 & 21.49042 & 110 & -3.9 & 1.8 & 24.8 \\
\hline DEBRECEN HU & 47.47051 & 21.49042 & 110 & -1.85 & 3 & 25.4 \\
\hline DEBRECEN HU & 47.47051 & 21.49042 & 110 & -4.1 & 9.5 & 25.4 \\
\hline DEBRECEN HU & 47.47051 & 21.49042 & 110 & 1.41 & 1.6 & 26 \\
\hline DEBRECEN HU & 47.47051 & 21.49042 & 110 & -2.29 & 10.1 & 26.5 \\
\hline DEBRECEN HU & 47.47051 & 21.49042 & 110 & 1.16 & 2.6 & 28 \\
\hline BRATISLAV,SK & 48.16905 & 17.11191 & 286 & -15.67 & 37.7 & -1.1 \\
\hline BRATISLAV,SK & 48.16905 & 17.11191 & 286 & -12.88 & 78 & -0.7 \\
\hline BRATISLAV,SK & 48.16905 & 17.11191 & 286 & -10.76 & 68.2 & -0.6 \\
\hline BRATISLAV,SK & 48.16905 & 17.11191 & 286 & -11.35 & 27 & -0.1 \\
\hline BRATISLAV,SK & 48.16905 & 17.11191 & 286 & -8.81 & 23 & 0.3 \\
\hline BRATISLAV,SK & 48.16905 & 17.11191 & 286 & -10.67 & 11.3 & 0.3 \\
\hline BRATISLAV,SK & 48.16905 & 17.11191 & 286 & -8.69 & 36.8 & 1.2 \\
\hline BRATISLAV,SK & 48.16905 & 17.11191 & 286 & -9.36 & 30.7 & 1.3 \\
\hline BRATISLAV,SK & 48.16905 & 17.11191 & 286 & -7.39 & 11 & 1.5 \\
\hline BRATISLAV,SK & 48.16905 & 17.11191 & 286 & -11.28 & 83.8 & 1.5 \\
\hline BRATISLAV,SK & 48.16905 & 17.11191 & 286 & -11.53 & 35 & 1.8 \\
\hline BRATISLAV,SK & 48.16905 & 17.11191 & 286 & -6.9 & 80 & 2 \\
\hline BRATISLAV,SK & 48.16905 & 17.11191 & 286 & -12.1 & 87 & 2 \\
\hline BRATISLAV,SK & 48.16905 & 17.11191 & 286 & -8.42 & 21 & 2.7 \\
\hline BRATISLAV, SK & 48.16905 & 17.11191 & 286 & -10.62 & 30 & 3.2 \\
\hline BRATISLAV,SK & 48.16905 & 17.11191 & 286 & -7.34 & 25 & 3.8 \\
\hline BRATISLAV,SK & 48.16905 & 17.11191 & 286 & -12.22 & 48.3 & 4.1 \\
\hline BRATISLAV,SK & 48.16905 & 17.11191 & 286 & -10.58 & 121 & 4.2 \\
\hline BRATISLAV,SK & 48.16905 & 17.11191 & 286 & -11.5 & 65.5 & 4.6 \\
\hline BRATISLAV,SK & 48.16905 & 17.11191 & 286 & -9.95 & 50.8 & 5.1 \\
\hline BRATISLAV,SK & 48.16905 & 17.11191 & 286 & -11.09 & 77 & 5.5 \\
\hline BRATISLAV,SK & 48.16905 & 17.11191 & 286 & -14.37 & 60.7 & 5.6 \\
\hline BRATISLAV,SK & 48.16905 & 17.11191 & 286 & -7.69 & 34.2 & 6.7 \\
\hline BRATISLAV,SK & 48.16905 & 17.11191 & 286 & -5.5 & 20 & 8.1 \\
\hline BRATISLAV,SK & 48.16905 & 17.11191 & 286 & -9.25 & 63.5 & 8.4 \\
\hline BRATISLAV,SK & 48.16905 & 17.11191 & 286 & -14.1 & 22.9 & 8.8 \\
\hline BRATISLAV,SK & 48.16905 & 17.11191 & 286 & -8.54 & 35.2 & 8.8 \\
\hline $5 K$ & 905 & 11191 & 286 & .25 & .7 & 8 \\
\hline
\end{tabular}




\begin{tabular}{|c|c|c|c|c|c|c|}
\hline BRATISLAV,SK & 48.16905 & 17.11191 & 286 & -8.34 & 24.9 & 9 \\
\hline BRATISLAV,SK & 48.16905 & 17.11191 & 286 & -9.41 & 19 & 9.7 \\
\hline BRATISLAV,SK & 48.16905 & 17.11191 & 286 & -0.86 & 11 & 10.1 \\
\hline BRATISLAV,SK & 48.16905 & 17.11191 & 286 & -7.42 & 23.2 & 10.1 \\
\hline BRATISLAV,SK & 48.16905 & 17.11191 & 286 & -9.25 & 54.3 & 10.5 \\
\hline BRATISLAV,SK & 48.16905 & 17.11191 & 286 & -6.27 & 52 & 10.6 \\
\hline BRATISLAV,SK & 48.16905 & 17.11191 & 286 & -9.58 & 16.7 & 10.9 \\
\hline BRATISLAV,SK & 48.16905 & 17.11191 & 286 & -2.54 & 32 & 11.3 \\
\hline BRATISLAV,SK & 48.16905 & 17.11191 & 286 & -7.62 & 107.6 & 11.3 \\
\hline BRATISLAV,SK & 48.16905 & 17.11191 & 286 & -6.87 & 71.5 & 13.1 \\
\hline BRATISLAV,SK & 48.16905 & 17.11191 & 286 & -2.65 & 62 & 14.7 \\
\hline BRATISLAV,SK & 48.16905 & 17.11191 & 286 & -8.24 & 94 & 15.1 \\
\hline BRATISLAV,SK & 48.16905 & 17.11191 & 286 & -6.31 & 73.1 & 15.7 \\
\hline BRATISLAV,SK & 48.16905 & 17.11191 & 286 & -2.63 & 37 & 15.8 \\
\hline BRATISLAV,SK & 48.16905 & 17.11191 & 286 & -1.95 & 24 & 16 \\
\hline BRATISLAV,SK & 48.16905 & 17.11191 & 286 & -10.25 & 45.4 & 16.1 \\
\hline BRATISLAV,SK & 48.16905 & 17.11191 & 286 & -6.76 & 54 & 16.2 \\
\hline BRATISLAV,SK & 48.16905 & 17.11191 & 286 & -3.6 & 77 & 16.5 \\
\hline BRATISLAV,SK & 48.16905 & 17.11191 & 286 & -5.24 & 82.3 & 16.6 \\
\hline BRATISLAV,SK & 48.16905 & 17.11191 & 286 & -5.5 & 40 & 17.7 \\
\hline BRATISLAV,SK & 48.16905 & 17.11191 & 286 & -5.9 & 53.7 & 17.8 \\
\hline BRATISLAV, SK & 48.16905 & 17.11191 & 286 & -3.98 & 20 & 18 \\
\hline BRATISLAV,SK & 48.16905 & 17.11191 & 286 & -6.01 & 50.5 & 18.4 \\
\hline BRATISLAV,SK & 48.16905 & 17.11191 & 286 & -6.37 & 70.5 & 18.8 \\
\hline BRATISLAV,SK & 48.16905 & 17.11191 & 286 & -13.58 & 96 & 19 \\
\hline BRATISLAV,SK & 48.16905 & 17.11191 & 286 & -8.14 & 21.8 & 19.2 \\
\hline BRATISLAV,SK & 48.16905 & 17.11191 & 286 & 4 & 35.8 & 19.6 \\
\hline BRATISLAV,SK & 48.16905 & 17.11191 & 286 & -4.81 & 107 & 19.9 \\
\hline BRATISLAV,SK & 48.16905 & 17.11191 & 286 & -6.49 & 59.3 & 20.2 \\
\hline BRATISLAV,SK & 48.16905 & 17.11191 & 286 & -3.83 & 104 & 20.3 \\
\hline BRATISLAV,SK & 48.16905 & 17.11191 & 286 & 0.66 & 24 & 21.1 \\
\hline BRATISLAV,SK & 48.16905 & 17.11191 & 286 & -9.05 & 6.1 & 21.6 \\
\hline MILHOSTO'SK & 48.65833 & 21.73 & 104 & -14.64 & 24.5 & -3.8 \\
\hline MILHOSTO'SK & 48.65833 & 21.73 & 104 & -13.19 & 34 & -3.7 \\
\hline MILHOSTO'SK & 48.65833 & 21.73 & 104 & -18.43 & 12.9 & -2.4 \\
\hline MILHOSTO'SK & 48.65833 & 21.73 & 104 & -13.56 & 10.4 & -2.1 \\
\hline MILHOSTO'SK & 48.65833 & 21.73 & 104 & -8.05 & 17 & -1.9 \\
\hline MILHOSTO'SK & 48.65833 & 21.73 & 104 & -15.89 & 13 & -1.7 \\
\hline MILHOSTO'SK & 48.65833 & 21.73 & 104 & -10.86 & 26.3 & -1.5 \\
\hline MILHOSTO'SK & 48.65833 & 21.73 & 104 & -8.15 & 14.2 & -1.1 \\
\hline MILHOSTO'SK & 48.65833 & 21.73 & 104 & -10.5 & 6.3 & -0.9 \\
\hline MILHOSTO'SK & 48.65833 & 21.73 & 104 & -13.06 & 13.3 & -0.5 \\
\hline MILHOSTO'SK & 48.65833 & 21.73 & 104 & -11.58 & 51 & -0.4 \\
\hline MILHOSTO'SK & 48.65833 & 21.73 & 104 & -10.08 & 11 & -0.1 \\
\hline MILHOSTO'SK & 48.65833 & 21.73 & 104 & -12.78 & 56 & 1.2 \\
\hline MILHOSTO'SK & 48.65833 & 21.73 & 104 & -12.28 & 40 & 1.2 \\
\hline MILHOSTO'SK & 48.65833 & 21.73 & 104 & -12.48 & 59.4 & 2.1 \\
\hline MILHOSTO'SK & 48.65833 & 21.73 & 104 & -15.24 & 24.3 & 2.6 \\
\hline MILHOSTO'SK & 48.65833 & 21.73 & 104 & -9.83 & 32 & 3 \\
\hline LHOSTO'SK & 65833 & .73 & 104 & -14.1 & 67 & \\
\hline
\end{tabular}




\begin{tabular}{|c|c|c|c|c|c|c|}
\hline MILHOSTO'SK & 48.65833 & 21.73 & 104 & -10.34 & 58.8 & 4.4 \\
\hline MILHOSTO'SK & 48.65833 & 21.73 & 104 & -11.18 & 20.7 & 4.6 \\
\hline MILHOSTO'SK & 48.65833 & 21.73 & 104 & -9.69 & 56.5 & 4.9 \\
\hline MILHOSTO'SK & 48.65833 & 21.73 & 104 & -8.83 & 8.9 & 6.3 \\
\hline MILHOSTO'SK & 48.65833 & 21.73 & 104 & -10.99 & 22 & 6.6 \\
\hline MILHOSTO'SK & 48.65833 & 21.73 & 104 & -7.64 & 4 & 7.6 \\
\hline MILHOSTO'SK & 48.65833 & 21.73 & 104 & -8.67 & 75 & 7.7 \\
\hline MILHOSTO'SK & 48.65833 & 21.73 & 104 & -9.38 & 93 & 8.5 \\
\hline MILHOSTO'SK & 48.65833 & 21.73 & 104 & -7.95 & 71.9 & 8.7 \\
\hline MILHOSTO'SK & 48.65833 & 21.73 & 104 & -9.92 & 123.3 & 8.8 \\
\hline MILHOSTO'SK & 48.65833 & 21.73 & 104 & -9.85 & 44.8 & 9.1 \\
\hline MILHOSTO'SK & 48.65833 & 21.73 & 104 & -13.57 & 38 & 9.3 \\
\hline MILHOSTO'SK & 48.65833 & 21.73 & 104 & -10.44 & 28 & 9.7 \\
\hline MILHOSTO'SK & 48.65833 & 21.73 & 104 & -9.76 & 30.1 & 9.8 \\
\hline MILHOSTO'SK & 48.65833 & 21.73 & 104 & -8.88 & 64.8 & 10.1 \\
\hline MILHOSTO'SK & 48.65833 & 21.73 & 104 & -6.5 & 26.7 & 10.2 \\
\hline MILHOSTO'SK & 48.65833 & 21.73 & 104 & -6.76 & 75 & 11.7 \\
\hline MILHOSTO'SK & 48.65833 & 21.73 & 104 & -6.1 & 48.8 & 12.5 \\
\hline MILHOSTO'SK & 48.65833 & 21.73 & 104 & -8.06 & 49.4 & 13 \\
\hline MILHOSTO'SK & 48.65833 & 21.73 & 104 & -7.75 & 56.2 & 13.8 \\
\hline MILHOSTO'SK & 48.65833 & 21.73 & 104 & -5.87 & 81 & 14.7 \\
\hline MILHOSTO'SK & 48.65833 & 21.73 & 104 & -11.44 & 44.1 & 14.8 \\
\hline MILHOSTO'SK & 48.65833 & 21.73 & 104 & -5.74 & 60 & 14.9 \\
\hline MILHOSTO'SK & 48.65833 & 21.73 & 104 & -4.63 & 94.8 & 15.1 \\
\hline MILHOSTO'SK & 48.65833 & 21.73 & 104 & -9.97 & 34 & 15.3 \\
\hline MILHOSTO'SK & 48.65833 & 21.73 & 104 & -9.25 & 12 & 15.4 \\
\hline MILHOSTO'SK & 48.65833 & 21.73 & 104 & -6.83 & 32.2 & 15.5 \\
\hline MILHOSTO'SK & 48.65833 & 21.73 & 104 & -9.93 & 86 & 16.9 \\
\hline MILHOSTO'SK & 48.65833 & 21.73 & 104 & -5.91 & 52 & 17 \\
\hline MILHOSTO'SK & 48.65833 & 21.73 & 104 & -4.23 & 56.7 & 17.8 \\
\hline MILHOSTO'SK & 48.65833 & 21.73 & 104 & -7.35 & 40.3 & 18.1 \\
\hline MILHOSTO'SK & 48.65833 & 21.73 & 104 & -5.61 & 29.7 & 18.2 \\
\hline MILHOSTO'SK & 48.65833 & 21.73 & 104 & -5.5 & 33.7 & 18.3 \\
\hline MILHOSTO'SK & 48.65833 & 21.73 & 104 & -3.65 & 45.9 & 18.5 \\
\hline MILHOSTO'SK & 48.65833 & 21.73 & 104 & -6.65 & 43 & 18.7 \\
\hline MILHOSTO'SK & 48.65833 & 21.73 & 104 & -6.01 & 52.3 & 18.9 \\
\hline MILHOSTO'SK & 48.65833 & 21.73 & 104 & -4.58 & 86.3 & 19.1 \\
\hline MILHOSTO'SK & 48.65833 & 21.73 & 104 & -12.44 & 43 & 19.2 \\
\hline MILHOSTO'SK & 48.65833 & 21.73 & 104 & -7.25 & 19.3 & 19.3 \\
\hline MILHOSTO'SK & 48.65833 & 21.73 & 104 & -6.44 & 66.5 & 19.3 \\
\hline MILHOSTO'SK & 48.65833 & 21.73 & 104 & -7.7 & 52 & 19.8 \\
\hline MILHOSTO'SK & 48.65833 & 21.73 & 104 & -7.84 & 55.8 & 19.9 \\
\hline MILHOSTO'SK & 48.65833 & 21.73 & 104 & -8.3 & 59 & 20.6 \\
\hline MILHOSTO'SK & 48.65833 & 21.73 & 104 & -5.01 & 66.1 & 20.6 \\
\hline MILHOSTO'SK & 48.65833 & 21.73 & 104 & -4.59 & 68.1 & 21.3 \\
\hline MOCHOVCISK & 48.28461 & 18.47571 & 206 & -13.16 & 32.5 & -3.5 \\
\hline MOCHOVCISK & 48.28461 & 18.47571 & 206 & -13.9 & 51.8 & -2.7 \\
\hline MOCHOVCISK & 48.28461 & 18.47571 & 206 & -15.46 & 16.3 & -2.6 \\
\hline MOCHOVCISK & 48.28461 & 18.47571 & 206 & -13.53 & 21 & -1.5 \\
\hline MOCHOVCISK & 48.28461 & 18.47571 & 206 & -17.17 & 10 & -1 \\
\hline
\end{tabular}




\begin{tabular}{|c|c|c|c|c|c|c|}
\hline MOCHOVCISK & 48.28461 & 18.47571 & 206 & -6.7 & 8.1 & -1.3 \\
\hline MOCHOVCISK & 48.28461 & 18.47571 & 206 & -13.98 & 62.6 & -1 \\
\hline MOCHOVCISK & 48.28461 & 18.47571 & 206 & -8.9 & 13 & -0.9 \\
\hline MOCHOVCISK & 48.28461 & 18.47571 & 206 & -11.05 & 72.9 & -0.9 \\
\hline MOCHOVCISK & 48.28461 & 18.47571 & 206 & -9.37 & 24.9 & -0.8 \\
\hline MOCHOVCISK & 48.28461 & 18.47571 & 206 & -8.86 & 12 & 0.1 \\
\hline MOCHOVCISK & 48.28461 & 18.47571 & 206 & -14.31 & 70 & 0.9 \\
\hline MOCHOVCISK & 48.28461 & 18.47571 & 206 & -12.13 & 52 & 1.7 \\
\hline MOCHOVCISK & 48.28461 & 18.47571 & 206 & -13.71 & 63 & \\
\hline MOCHOVCISK & 48.28461 & 18.47571 & 206 & -12.11 & 19 & 2.1 \\
\hline MOCHOVCISK & 48.28461 & 18.47571 & 206 & -10.05 & 15.5 & 2.3 \\
\hline MOCHOVCISK & 48.28461 & 18.47571 & 206 & -9.24 & 41 & 2.4 \\
\hline MOCHOVCISK & 48.28461 & 18.47571 & 206 & -11.98 & 70 & 2.8 \\
\hline MOCHOVCISK & 48.28461 & 18.47571 & 206 & -16.18 & 52.3 & 3.5 \\
\hline MOCHOVCISK & 48.28461 & 18.47571 & 206 & -10.66 & 12.1 & 3.5 \\
\hline MOCHOVCISK & 48.28461 & 18.47571 & 206 & -10.39 & 30.7 & \\
\hline MOCHOVCISK & 48.28461 & 18.47571 & 206 & -8.98 & 114.4 & 4.4 \\
\hline MOCHOVCISK & 48.28461 & 18.47571 & 206 & -9.36 & 81.9 & \\
\hline MOCHOVCISK & 48.28461 & 18.47571 & 206 & -9.88 & 33 & 6.3 \\
\hline MOCHOVCISK & 48.28461 & 18.47571 & 206 & -11.04 & 25.6 & 6.6 \\
\hline MOCHOVCISK & 48.28461 & 18.47571 & 206 & -7.07 & 16.1 & 6.9 \\
\hline MOCHOVCISK & 48.28461 & 18.47571 & 206 & -12.87 & 21.1 & 7.9 \\
\hline MOCHOVCISK & 48.28461 & 18.47571 & 206 & -8.94 & 31.5 & 8.5 \\
\hline MOCHOVCISK & 48.28461 & 18.47571 & 206 & -9.39 & 64.6 & 8.5 \\
\hline MOCHOVCISK & 48.28461 & 18.47571 & 206 & -9.31 & 23 & 8.6 \\
\hline MOCHOVCISK & 48.28461 & 18.47571 & 206 & -10.85 & 75.9 & 8.8 \\
\hline MOCHOVCISK & 48.28461 & 18.47571 & 206 & -10.64 & 74.2 & 9.7 \\
\hline MOCHOVCISK & 48.28461 & 18.47571 & 206 & -8.27 & 16 & 9.9 \\
\hline MOCHOVCISK & 48.28461 & 18.47571 & 206 & -7.56 & 34.6 & 10.6 \\
\hline MOCHOVCISK & 48.28461 & 18.47571 & 206 & -10.27 & 18.5 & 10.6 \\
\hline MOCHOVCISK & 48.28461 & 18.47571 & 206 & -6.07 & 46 & 11.2 \\
\hline MOCHOVCISK & 48.28461 & 18.47571 & 206 & -7.02 & 75.9 & 11.5 \\
\hline MOCHOVCISK & 48.28461 & 18.47571 & 206 & -7.21 & 58.8 & 12.3 \\
\hline MOCHOVCISK & 48.28461 & 18.47571 & 206 & -6.81 & 68 & 13.7 \\
\hline MOCHOVCISK & 48.28461 & 18.47571 & 206 & -7.58 & 58 & 14.8 \\
\hline MOCHOVCISK & 48.28461 & 18.47571 & 206 & -2.68 & 19 & 14.8 \\
\hline MOCHOVCISK & 48.28461 & 18.47571 & 206 & -7.94 & 62 & 15.1 \\
\hline MOCHOVCISK & 48.28461 & 18.47571 & 206 & -6.72 & 16 & 15.4 \\
\hline MOCHOVCISK & 48.28461 & 18.47571 & 206 & -8.95 & 31.9 & 15.5 \\
\hline MOCHOVCISK & 48.28461 & 18.47571 & 206 & -7.36 & 21.2 & 15.7 \\
\hline MOCHOVCISK & 48.28461 & 18.47571 & 206 & -6.74 & 85 & 15.8 \\
\hline MOCHOVCISK & 48.28461 & 18.47571 & 206 & -6 & 48.7 & 16.6 \\
\hline MOCHOVCISK & 48.28461 & 18.47571 & 206 & -6.34 & 29 & 16.7 \\
\hline MOCHOVCISK & 48.28461 & 18.47571 & 206 & -5.29 & 54.7 & 17.1 \\
\hline MOCHOVCISK & 48.28461 & 18.47571 & 206 & -7.36 & 15.5 & 18.1 \\
\hline MOCHOVCISK & 48.28461 & 18.47571 & 206 & -6.07 & 55.3 & 18.2 \\
\hline MOCHOVCISK & 48.28461 & 18.47571 & 206 & -11.72 & 53 & 18.6 \\
\hline MOCHOVCISK & 48.28461 & 18.47571 & 206 & -5.59 & 37.2 & 18.7 \\
\hline MOCHOVCISK & 48.28461 & 18.47571 & 206 & -5.71 & 69 & 1. \\
\hline MOCHOVCISK & 48.28461 & 18.47571 & 206 & -7.98 & 122 & 19 \\
\hline
\end{tabular}




\begin{tabular}{|c|c|c|c|c|c|c|}
\hline MOCHOVCISK & 48.28461 & 18.47571 & 206 & -9.61 & 75.9 & 19.2 \\
\hline MOCHOVCISK & 48.28461 & 18.47571 & 206 & -6.62 & 25.5 & 19.4 \\
\hline MOCHOVCISK & 48.28461 & 18.47571 & 206 & -6.67 & 16.6 & 19.9 \\
\hline MOCHOVCISK & 48.28461 & 18.47571 & 206 & -4.49 & 12 & 20.2 \\
\hline MOCHOVCISK & 48.28461 & 18.47571 & 206 & -3.1 & 26.8 & 20.3 \\
\hline MOCHOVCISK & 48.28461 & 18.47571 & 206 & -6.44 & 125.1 & 21.3 \\
\hline MOCHOVCISK & 48.28461 & 18.47571 & 206 & -7.81 & 30.1 & 21.3 \\
\hline TOPOLNIKYSK & 47.96013 & 17.86201 & 118 & -15.45 & 18.5 & -2.5 \\
\hline TOPOLNIKYSK & 47.96013 & 17.86201 & 118 & -15.11 & 12.8 & -2.2 \\
\hline TOPOLNIKYSK & 47.96013 & 17.86201 & 118 & -14.26 & 32.4 & -1.1 \\
\hline TOPOLNIKYSK & 47.96013 & 17.86201 & 118 & -7.92 & 3.7 & -0.3 \\
\hline TOPOLNIKYSK & 47.96013 & 17.86201 & 118 & -14.01 & 15.8 & -0.1 \\
\hline TOPOLNIKY SK & 47.96013 & 17.86201 & 118 & -10.35 & 2.6 & 0.2 \\
\hline TOPOLNIKYSK & 47.96013 & 17.86201 & 118 & -12.65 & 15 & 0.4 \\
\hline TOPOLNIKYSK & 47.96013 & 17.86201 & 118 & -14.94 & 76.3 & 0.4 \\
\hline TOPOLNIKYSK & 47.96013 & 17.86201 & 118 & -12.14 & 7 & 1.3 \\
\hline TOPOLNIKY SK & 47.96013 & 17.86201 & 118 & -7.92 & 20 & 1.5 \\
\hline TOPOLNIKYSK & 47.96013 & 17.86201 & 118 & -12.19 & 18 & 2.7 \\
\hline TOPOLNIKY SK & 47.96013 & 17.86201 & 118 & -12.06 & 70 & 3 \\
\hline TOPOLNIKY SK & 47.96013 & 17.86201 & 118 & -11.64 & 19 & 3 \\
\hline TOPOLNIKYSK & 47.96013 & 17.86201 & 118 & -7.31 & 7.8 & 3.4 \\
\hline TOPOLNIKYSK & 47.96013 & 17.86201 & 118 & -12.42 & 39 & 4.1 \\
\hline TOPOLNIKY SK & 47.96013 & 17.86201 & 118 & -13.36 & 10 & 4.1 \\
\hline TOPOLNIKYSK & 47.96013 & 17.86201 & 118 & -16.42 & 22.4 & 4.1 \\
\hline TOPOLNIKYSK & 47.96013 & 17.86201 & 118 & -8.42 & 117.2 & 5.2 \\
\hline TOPOLNIKYSK & 47.96013 & 17.86201 & 118 & -9.59 & 45.3 & 5.2 \\
\hline TOPOLNIKY SK & 47.96013 & 17.86201 & 118 & -6.06 & 41.2 & 5.6 \\
\hline TOPOLNIKYSK & 47.96013 & 17.86201 & 118 & -10.23 & 49.3 & 5.8 \\
\hline TOPOLNIKYSK & 47.96013 & 17.86201 & 118 & -10.76 & 25.6 & 7.1 \\
\hline TOPOLNIKYSK & 47.96013 & 17.86201 & 118 & -9.82 & 17 & 8.1 \\
\hline TOPOLNIKYSK & 47.96013 & 17.86201 & 118 & -8.4 & 24.2 & 8.8 \\
\hline TOPOLNIKYSK & 47.96013 & 17.86201 & 118 & -8.36 & 68.7 & 9.1 \\
\hline TOPOLNIKYSK & 47.96013 & 17.86201 & 118 & -11.02 & 45.1 & 9.2 \\
\hline TOPOLNIKYSK & 47.96013 & 17.86201 & 118 & -5.55 & 6 & 10.1 \\
\hline TOPOLNIKY SK & 47.96013 & 17.86201 & 118 & -10.37 & 5 & 10.2 \\
\hline TOPOLNIKYSK & 47.96013 & 17.86201 & 118 & -8.19 & 9 & 10.4 \\
\hline TOPOLNIKYSK & 47.96013 & 17.86201 & 118 & -10.28 & 65.8 & 10.8 \\
\hline TOPOLNIKY SK & 47.96013 & 17.86201 & 118 & -9.12 & 27.6 & 11 \\
\hline TOPOLNIKYSK & 47.96013 & 17.86201 & 118 & -7.95 & 4.6 & 11.3 \\
\hline TOPOLNIKYSK & 47.96013 & 17.86201 & 118 & -6.23 & 37 & 11.4 \\
\hline TOPOLNIKYSK & 47.96013 & 17.86201 & 118 & -8.86 & 71.3 & 12.2 \\
\hline TOPOLNIKYSK & 47.96013 & 17.86201 & 118 & -8.62 & 48.5 & 13.7 \\
\hline TOPOLNIKYSK & 47.96013 & 17.86201 & 118 & -5.69 & 40 & 14.8 \\
\hline TOPOLNIKYSK & 47.96013 & 17.86201 & 118 & -7.71 & 15 & 15.5 \\
\hline TOPOLNIKY SK & 47.96013 & 17.86201 & 118 & -3.33 & 59 & 15.7 \\
\hline TOPOLNIKYSK & 47.96013 & 17.86201 & 118 & -3.5 & 18.6 & 16.1 \\
\hline TOPOLNIKYSK & 47.96013 & 17.86201 & 118 & -8.4 & 29.8 & 16.1 \\
\hline TOPOLNIKYSK & 47.96013 & 17.86201 & 118 & -8.67 & 19 & 16.4 \\
\hline TOPOLNIKYSK & 47.96013 & 17.86201 & 118 & -6.25 & 9.2 & 16.9 \\
\hline TOPOLNIKY SK & 47.96013 & 17.86201 & 118 & -4.33 & 9 & 17 \\
\hline
\end{tabular}




$\begin{array}{lrrrrrr}\text { TOPOLNIKYSK } & 47.96013 & 17.86201 & 118 & -4.37 & 23 & 17.9 \\ \text { TOPOLNIKYSK } & 47.96013 & 17.86201 & 118 & -6.9 & 44.4 & 18 \\ \text { TOPOLNIKYSK } & 47.96013 & 17.86201 & 118 & -12.59 & 60 & 19.2 \\ \text { TOPOLNIKYSK } & 47.96013 & 17.86201 & 118 & -4.03 & 42.9 & 19.2 \\ \text { TOPOLNIKYSK } & 47.96013 & 17.86201 & 118 & -3.11 & 45.7 & 19.3 \\ \text { TOPOLNIKYSK } & 47.96013 & 17.86201 & 118 & -6.95 & 76.1 & 19.4 \\ \text { TOPOLNIKYSK } & 47.96013 & 17.86201 & 118 & -9.02 & 104.5 & 19.5 \\ \text { TOPOLNIKYSK } & 47.96013 & 17.86201 & 118 & -10.51 & 29.1 & 19.9 \\ \text { TOPOLNIKYSK } & 47.96013 & 17.86201 & 118 & -4.97 & 14.1 & 20.2 \\ \text { TOPOLNIKYSK } & 47.96013 & 17.86201 & 118 & -7.81 & 146 & 20.4 \\ \text { TOPOLNIKYSK } & 47.96013 & 17.86201 & 118 & -7.01 & 37 & 20.9 \\ \text { TOPOLNIKYSK } & 47.96013 & 17.86201 & 118 & -9.91 & 63.6 & 21.3 \\ \text { TOPOLNIKYSK } & 47.96013 & 17.86201 & 118 & -4.97 & 49.2 & 21.8 \\ \text { TOPOLNIKYSK } & 47.96013 & 17.86201 & 118 & -11.9 & 52 & 22\end{array}$




\begin{tabular}{|c|c|c|c|c|c|}
\hline Species & Family & Locality & Material & d180_PO3 & d180_W \\
\hline Rangifer tarandus & Cervidae & Svalbard Islands & bone & 12.9 & -10.0 \\
\hline Rangifer tarandus & Cervidae & Svalbard Islands & bone & 12.4 & -10.0 \\
\hline Rangifer tarandus & Cervidae & Svalbard Islands & bone & 11.9 & -10.0 \\
\hline Rangifer tarandus & Cervidae & Svalbard Islands & tooth & 14.5 & -10.0 \\
\hline Rangifer tarandus & Cervidae & Svalbard Islands & tooth & 12.7 & -10.0 \\
\hline Rangifer tarandus & Cervidae & Svalbard Islands & tooth & 11.6 & -10.0 \\
\hline Rangifer tarandus & Cervidae & Lapponia-Rovaniemi & bone & 13.0 & -12.0 \\
\hline Rangifer tarandus & Cervidae & Lapponia-Rovaniemi & bone & 12.1 & -12.0 \\
\hline Rangifer tarandus & Cervidae & Lapponia-Rovaniemi & bone & 11.8 & -12.0 \\
\hline Rangifer tarandus & Cervidae & Lapponia-Rovaniemi & bone & 11.6 & -12.0 \\
\hline Rangifer tarandus & Cervidae & Lapponia-Rovaniemi & bone & 11.3 & -12.0 \\
\hline Rangifer tarandus & Cervidae & Lapponia-Rovaniemi & bone & 11.1 & -12.0 \\
\hline Rangifer tarandus & Cervidae & Lapponia-Rovaniemi & bone & 10.9 & -12.0 \\
\hline Rangifer tarandus & Cervidae & Lapponia-Rovaniemi & bone & 10.8 & -12.0 \\
\hline Rangifer tarandus & Cervidae & Lapponia-Rovaniemi & bone & 10.5 & -12.0 \\
\hline Rangifer tarandus & Cervidae & Lapponia-Rovaniemi & bone & 9.9 & -12.0 \\
\hline Rangifer tarandus & Cervidae & Lapponia-Rovaniemi & bone & 10.8 & -12.0 \\
\hline Rangifer tarandus & Cervidae & Norwegian Lapland & tooth & 12.1 & -12.5 \\
\hline Rangifer tarandus & Cervidae & Norwegian Lapland & tooth & 11.4 & -12.5 \\
\hline Rangifer tarandus & Cervidae & Novaya Zemlya & bone & 8.9 & -16.0 \\
\hline Rangifer tarandus & Cervidae & Novaya Zemlya & tooth & 10.8 & -16.0 \\
\hline Rangifer tarandus & Cervidae & Novaya Zemlya & tooth & 10.8 & -16.0 \\
\hline Rangifer tarandus & Cervidae & Novaya Zemlya & tooth & 10.6 & -16.0 \\
\hline Rangifer tarandus & Cervidae & Novaya Zemlya & tooth & 8.3 & -16.0 \\
\hline Rangifer tarandus & Cervidae & Novaya Zemlya & tooth & 7.9 & -16.0 \\
\hline Rangifer tarandus & Cervidae & Belyj Island & tooth & 10.0 & -18.0 \\
\hline Rangifer tarandus & Cervidae & Belyj Island & tooth & 7.9 & -18.0 \\
\hline Rangifer tarandus & Cervidae & Siberyhova Island & tooth & 8.6 & -18.0 \\
\hline Rangifer tarandus & Cervidae & Siberyhova Island & tooth & 7.0 & -18.0 \\
\hline Rangifer tarandus & Cervidae & Nadym river & bone & 6.9 & -18.5 \\
\hline Rangifer tarandus & Cervidae & Nadym river & tooth & 9.0 & -18.5 \\
\hline Rangifer tarandus & Cervidae & Nadym river & tooth & 6.3 & -18.5 \\
\hline Rangifer tarandus & Cervidae & Nadym river & tooth & 5.4 & -18.5 \\
\hline Rangifer tarandus & Cervidae & Nadym river & tooth & 5.4 & -18.5 \\
\hline Rangifer tarandus & Cervidae & Faddeevsky Island & bone & 6.3 & -24.0 \\
\hline Rangifer tarandus & Cervidae & Bel'kovsky Island & bone & 7.6 & -24.0 \\
\hline Sus scrofa & Suidae & Haute-Savoie & bone & 14.1 & -10.0 \\
\hline Sus scrofa & Suidae & Vienna & bone & 14.3 & -10.0 \\
\hline Sus scrofa & Suidae & Lorraine & bone & 15.4 & -8.0 \\
\hline Sus scrofa & Suidae & Sicily & bone & 16.4 & -7.4 \\
\hline Sus scrofa & Suidae & Ile de France & bone & 16.7 & -7.2 \\
\hline Sus scrofa & Suidae & Normandie & bone & 17.0 & -6.8 \\
\hline Sus scrofa & Suidae & Tuscany & bone & 17.2 & -6.3 \\
\hline Bos primigenius & Bovidae & Wyoming & tooth & 13.9 & -13.8 \\
\hline Bos primigenius & Bovidae & Wyoming & tooth & 9.7 & -21.4 \\
\hline Cervus canadensis & Cervidae & Wyoming & tooth & 13.8 & -13.8 \\
\hline Cervus canadensis & Cervidae & Wyoming & tooth & 9.8 & -21.4 \\
\hline Cervus canadensis & Cervidae & Croatia & tooth & 16.8 & -6.3 \\
\hline Cervus canadensis & Cervidae & Croatia & tooth & 14.3 & -12.0 \\
\hline
\end{tabular}




$\begin{array}{ll}\text { Bovidae } & \text { Iceland } \\ \text { Bovidae } & \text { Iceland } \\ \text { Bovidae } & \text { York } \\ \text { Bovidae } & \text { York } \\ \text { Bovidae } & \text { York } \\ \text { Bovidae } & \text { York } \\ \text { Suidae } & \text { Philippines } \\ \text { Suidae } & \text { Philippines } \\ \text { Cervidae } & \text { Bayerische Wald } \\ \text { Cervidae } & \text { Bialowiecza Park } \\ \text { Cervidae } & \text { Abruzzo Park } \\ \text { Cervidae } & \text { Inland Napier } \\ \text { Cervidae } & \text { Bas Rhin } \\ \text { Cervidae } & \text { Haute Marne } \\ \text { Cervidae } & \text { Pisa }\end{array}$

Cervidae

$\begin{array}{cll}\text { tooth } & 16.9 & -6.5 \\ \text { tooth } & 14.3 & -8.5 \\ \text { tooth } & 19.0 & -5.6 \\ \text { tooth } & 15.6 & -8.7 \\ \text { tooth } & 18.2 & -5.6 \\ \text { tooth } & 15.9 & -8.7 \\ \text { tooth } & 17.7 & -2.9 \\ \text { tooth } & 15.9 & -6.2 \\ \text { bone } & 12.79 & -11.5 \\ \text { bone } & 12.78 & -11.0 \\ \text { bone } & 14.90 & -9.4 \\ \text { bone } & 16.40 & -8.2 \\ \text { bone } & 16.50 & -8.0 \\ \text { bone } & 16.80 & -7.7 \\ \text { bone } & 18.38 & -6.3\end{array}$

Ovis aries
Ovis aries
Ovis aries
Ovis aries
Bos primigenius
Bos primigenius
Sus scrofa
Sus scrofa
Cervus elaphus
Cervus elaphus
Cervus elaphus
Cervus elaphus
Cervus elaphus
Cervus elaphus
Dama dama

Ovis aries 
literautre

lacumin \& Longinelli 2002

lacumin \& Longinelli 2002

lacumin \& Longinelli 2002

lacumin \& Longinelli 2002

lacumin \& Longinelli 2002

lacumin \& Longinelli 2002

lacumin \& Longinelli 2002

lacumin \& Longinelli 2002

lacumin \& Longinelli 2002

lacumin \& Longinelli 2002

lacumin \& Longinelli 2002

lacumin \& Longinelli 2002

lacumin \& Longinelli 2002

lacumin \& Longinelli 2002

lacumin \& Longinelli 2002

lacumin \& Longinelli 2002

lacumin \& Longinelli 2002

lacumin \& Longinelli 2002

lacumin \& Longinelli 2002

lacumin \& Longinelli 2002

lacumin \& Longinelli 2002

lacumin \& Longinelli 2002

lacumin \& Longinelli 2002

lacumin \& Longinelli 2002

lacumin \& Longinelli 2002

lacumin \& Longinelli 2002

lacumin \& Longinelli 2002

lacumin \& Longinelli 2002

lacumin \& Longinelli 2002

lacumin \& Longinelli 2002

lacumin \& Longinelli 2002

lacumin \& Longinelli 2002

lacumin \& Longinelli 2002

lacumin \& Longinelli 2002

lacumin \& Longinelli 2002

lacumin \& Longinelli 2002

Longinelli 1984

Longinelli 1984

Longinelli 1984

Longinelli 1984

Longinelli 1984

Longinelli 1984

Longinelli 1984

Frick, Clyde \& O'neil, 1998

Frick, Clyde \& O'neil, 1998

Frick, Clyde \& O'neil, 1998

Frick, Clyde \& O'neil, 1998

Frick, Clyde \& O'neil, 1998

Frick, Clyde \& O'neil, 1998 
Frick, Clyde \& O'neil, 1998 Frick, Clyde \& O'neil, 1998 Frick, Clyde \& O'neil, 1998 Frick, Clyde \& O'neil, 1998 Frick, Clyde \& O'neil, 1998 Frick, Clyde \& O'neil, 1998 Frick, Clyde \& O'neil, 1998 Frick, Clyde \& O'neil, 1998 D'Angela \& Longinelli, 1990 D'Angela \& Longinelli, 1990 D'Angela \& Longinelli, 1990 D'Angela \& Longinelli, 1990 D'Angela \& Longinelli, 1990 D'Angela \& Longinelli, 1990 D'Angela \& Longinelli, 1990 